\title{
Liberdade de imprensa no Império brasileiro
}

\section{Os debates parlamentares (1820-1840)}

Dissertação apresentada ao Programa de Pós-Graduação em História Social do Departamento de História da Faculdade de Filosofia, Letras e Ciências Humanas da Universidade de São Paulo, para a obtenção do título de Mestre em História.

Orientador: Profa. Dra. Miriam Dolhnikoff 


\section{Sumário}

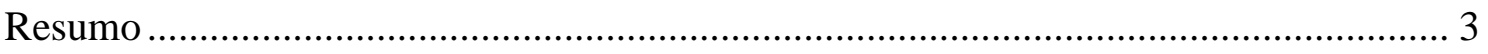

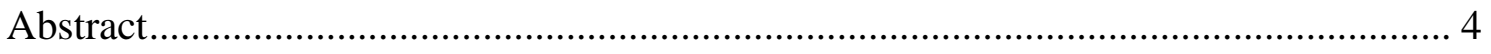

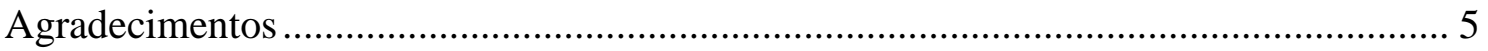

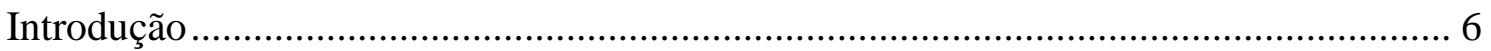

Capítulo 1: Controle da imprensa e da opinião: a legislação portuguesa ........................ 17

Capítulo 2: Imprensa e legislação no Brasil: 1820-1824 .............................................. 35

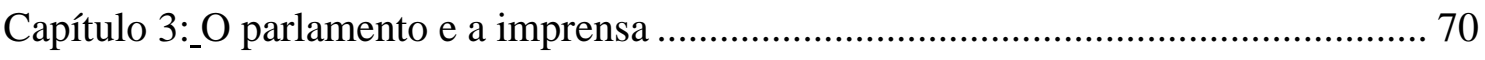

Capítulo 4:_Publicidade dos atos da Câmara .................................................................. 109

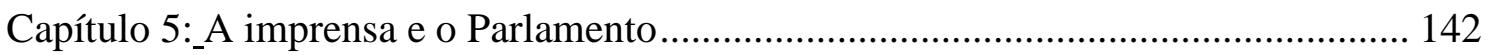

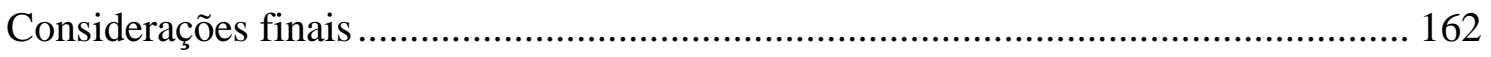

Fontes e referências bibliográficas .................................................................. 168 


\section{Resumo}

Este trabalho analisa os debates parlamentares sobre a legislação da atividade de imprensa e a publicação dos trabalhos da Câmara dos Deputados durante o período de 1820 a 1840. São aspectos que se relacionam intimamente com a construção de um Estado monárquico-constitucional-representativo, por serem a liberdade de expressão, e consequentemente a de imprensa, assim como a publicidade dos atos governamentais, dois dos pilares deste sistema de governo. O objetivo é compreender de que maneira os deputados exploravam politicamente estes preceitos liberais e a forma por eles encontrada para corporificá-los nas instituições do império brasileiro.

Palavras-chave: Brasil Império, Liberdade de imprensa, Publicidade, Representação, Liberalismo.

\section{E-mail para contato: tassiatoffoli@usp.br}




\begin{abstract}
This study analyses the parliamentary debates on press legislation and the publicity of the works of the Chamber of Deputies concerning the period between 1820 and 1840 . These are issues closely related to the construction of a monarchic, constitutional and representative State, in the sense that freedom of expression - and therefore press freedom - are, together with the publicity of government acts, two of the pillars that sustain this system of government. The objective is to understand in what ways the legislators made these liberal concepts politically useful, as well as how were these concepts incorporated into the institutions of the Brazilian Empire.
\end{abstract}

Key words: Imperial Brazil, freedom of press, publicity, representation, liberalism. 


\section{Agradecimentos}

Os agradecimentos e as dedicatórias sempre foram a primeira leitura que fiz de todos os livros, teses e dissertações que me passaram pelas mãos. Desses, o mais emocionante é, sem dúvida, o que Marc Bloch fez a Lucien Febvre na sua Apologia da História, à guisa de dedicatória: "[se este livro for publicado, nenhum] outro nome que não o seu, querido amigo, será então inscrito na página de guarda. Sente que se impõe tal nome, em tal lugar: única evocação consentida a uma ternura profunda demais e sagrada demais para suportar até ser dita”. Todo o texto poderia ser reproduzido aqui, por isso encerro logo a citação, arbitrariamente.

Desde então, este foi o tom que procurei em todas as dedicatórias, inclusive a minha. Infelizmente, chegada a hora não sou capaz de escrever qualquer coisa semelhante. Este registro está, assim, muito aquém de meus sentimentos.

Primeiramente, agradeço à Fundação Biblioteca Nacional e à Fapesp pelas bolsas de pesquisa concedidas durante o último ano e meio deste mestrado.

Minha orientadora, Miriam Dolhnikoff, teve paciência de Jó para lidar com o meu tempo de produção, e creio ter sido esta sua maior contribuição para minha formação, além, é claro, de toda a História que me ensinou. Mônica Dantas e Andréa Slemian fizeram observações precisas na qualificação do primeiro relatório desta pesquisa, que ajudaram muito sua evolução. Espero que sintam a melhora que estimularam (e de modo nenhum têm responsabilidade em caso negativo).

José Carlos Durand e Ian Packer foram companhias fundamentais durante os primeiros anos do mestrado, propiciando um agradabilíssimo ambiente de trabalho que sei que nunca mais encontrarei igual.

Aos amigos, agradeço principalmente pela boa companhia e compreensão das minhas ausências ou presenças ansiosas e monotemáticas. As primeiras, cometi com mais freqüência contra os mais antigos, espalhados que estamos por algumas cidades e tantos afazeres que inviabilizaram uma convivência mais próxima. As segundas foram aturadas pelos feitos na graduação. Não posso deixar de dizer que o Zé, o Ernesto e a Talita deram mais sentido ao bacharelado em Relações Internacionais.

A companhia do Julio foi - é - inestimável, “porque também, sem um carinho, ninguém segura esse rojão".

E é à minha família, especialmente meus pais e irmãos, que eu dedico este trabalho, muito deles também, já que sempre acreditaram em mim muito mais do que eu mesma. 


\section{Introdução}

Este trabalho estuda os debates parlamentares sobre a legislação dos abusos de imprensa e também o esforço da Câmara dos Deputados para a publicização de seus trabalhos a fim de compreender de que maneira estes agentes políticos se relacionavam com a nascente esfera pública brasileira. Assume-se aqui a centralidade desta instância para a política liberal do século XIX, que tinha como um de seus pressupostos de legitimidade a livre discussão de idéias e atos do governo e, para tanto, eram necessárias a publicidade destas ações e leis que permitissem que as opiniões a esse respeito circulassem sem grandes embaraços. Também se apresenta aqui uma breve resenha dos diálogos estabelecidos entre alguns periódicos e o poder legislativo durante o período, com o intuito de demonstrar os pontos de contato entre as idéias defendidas na Câmara e nos jornais, mesmo aqueles que não se alinhavam com ela.

A historiografia atenta cada vez mais para a imprensa do século XIX. Na verdade, os jornais produzidos na época sempre foram, e ainda são, utilizados como documentos pelos pesquisadores, que neles encontravam vestígios sobre o pensamento político dos agentes que analisavam e sobre o clima político em que se desenrolavam suas ações. É o caso, por exemplo, de Tobias Barreto e Otávio Tarquínio de Sousa ${ }^{1}$.

Essa produção, no entanto, não faz uma reflexão a respeito da produção dos periódicos, do seu significado num momento maior de mudanças na cultura e nas instituições políticas, ou mesmo do papel que os jornais desempenharam nas disputas que envolveram a formatação dessas últimas. Análises propriamente políticas da atividade jornalística na sociedade brasileira do século XIX tomam impulso em meados da década de 1940, com as obras de Hélio Vianna, Contribuição à história da imprensa: 1812-1869, e de Carlos Rizzini, O livro, o jornal e a tipografia no Brasil².

O primeiro estudo "setoriza" a imprensa, dividindo-a em amostras de jornalismo científico, acadêmico, eleitoral e dando prioridade à descrição dos jornais pioneiros em cada área. Já o segundo traz uma história geral da tipografia, para em seguida analisar,

\footnotetext{
${ }^{1}$ Tobias Monteiro. História do império: o primeiro reinado. Belo Horizonte: Itatiaia, São Paulo: EDUSP, 1982; Otávio Tarquínio de Sousa. Fatos e personagens em torno de um regime. Belo Horizonte: Itatiaia, São Paulo: EDUSP, 1988. Publicados originalmente em 1927 e 1957, respectivamente.

${ }^{2}$ Hélio Vianna. Contribuição à história da imprensa: 1812-1869. Rio de Janeiro: Imprensa Nacional, 1945; Carlos Rizzini. O livro, o jornal e a tipografia no Brasil, 1500-1822: com um breve estudo geral sobre a informação. Edição Fac-similar. São Paulo: Imprensa Oficial do Estado, 1988 (originalmente publicado em 1945).
} 
por meio de levantamento meticuloso, a produção impressa no Brasil desde a colônia até a independência. E ambos descrevem as campanhas políticas encetadas pelos jornais, tentando avaliar o peso que tiveram para as mobilizações.

Os dois livros influenciaram muito o trabalho de Nelson Werneck Sodré, História da imprensa no Brasil, publicado em $1966^{3}$. Nele, Sodré disponibiliza um levantamento colossal de jornais, revistas e pasquins combinado a análises que relacionam diretamente o sucesso ou insucesso das publicações ao momento político, fortalecendo assim o nexo entre os jornais e a política oitocentista.

Outra obra importante, publicada alguns anos depois, é a Sociologia da Imprensa Brasileira, de José Marques de Melo. Nela o autor discute os motivos do atraso e da implantação da tipografia no Brasil, relacionando-os não somente com motivos políticos, como a transferência da Corte de Portugal para a colônia, mas especialmente com necessidades sociais, como a organização da burocracia pública e privada e a demanda por informação a respeito de produtos, serviços, ações políticas e econômicas ${ }^{4}$. Desse modo, o nascimento da imprensa brasileira é apresentado como uma conseqüência da modernização da sociedade, ponto de vista inegavelmente distinto daquele defendido pelos trabalhos que lhe precediam, que enfatizavam a relação imprensa-Estado.

Também em outra chave de interpretação está o trabalho de Arnaldo Contier, Imprensa e ideologia em São Paulo ${ }^{5}$. O autor analisa periódicos paulistas da primeira metade do século XIX, mapeando o uso político de determinadas palavras, como ideologia, partido, Coroa, a fim de compreender os diferentes significados atribuídos a cada uma por cada facção política. Essa é uma vertente de estudos que será muito explorada a partir de então; um exemplo recente é o artigo de Ivana Stolze Lima, Cabra gente brasileira do gentio da Guiné: imprensa, política e identidade no Rio de Janeiro $(1831-1833)^{6}$, no qual a autora busca compreender de que maneira adjetivos raciais (como mulato, cabrito, meia-cara, etc) eram utilizados para identificar ou denegrir partidos políticos.

A produção historiográfica mais recente tem estudado a imprensa oitocentista especialmente como um espaço de exercício da política liberal, mas não somente como

\footnotetext{
${ }^{3}$ Nelson Werneck Sodré. História da Imprensa no Brasil. Rio de Janeiro: Mauad, 1999.

${ }^{4}$ José Marques de Melo. Sociologia da Imprensa Brasileira. A implantação. Petrópolis: Vozes, 1973.

${ }^{5}$ Arnaldo Daraya Contier, Imprensa e ideologia em São Paulo. Petrópolis: Vozes, 1979.

${ }^{6}$ In História e imprensa. Representações culturais e práticas de poder. Lucia Maria Bastos Pereira Neves, Marco Morel, Tania Maria Bessone Ferreira (orgs.). Rio de Janeiro: DP\&A: Faperj, 2006.
} 
arena na qual se digladiavam projetos para o país. A incorporação do conceito de esfera pública $^{7}$ possibilitou novas abordagens sobre as transformações na cultura política brasileira e, assim, os jornais passaram a ser analisados como construtores de novas identidades políticas e como espaços capazes de agregar forças de agentes politicamente próximos.

Nesse sentido, o trabalho de Marco Morel $^{8}$ avança ao relacionar a intensa atividade jornalística do período à militância das sociedades secretas (especialmente a maçonaria) e à ocupação de largos, praças e ruas por manifestações ou mesmo vozes e gritos, todos aspectos da formação do espaço público brasileiro, que aos poucos ia ganhando o caráter de lugar privilegiado para o exercício da política. Valoriza-se, dessa forma, o caráter público da política liberal do século XIX, e atribui-se aos periódicos e pasquins grande importância para a compreensão das possibilidades de organização política e social percebidas pelos agentes históricos envolvidos nas disputas da época.

De fato, o campo mais profícuo desta produção é o do estudo dos projetos para o Brasil defendidos pelos periódicos e a articulação política por eles permitida. Isabel Lustosa $^{9}$, por exemplo, dedica-se a esmiuçar a batalha travada por periódicos, pasquins e folhetos em torno dos projetos políticos em voga na época da independência, desde as discussões sobre a conveniência ou não da emancipação em relação a Portugal até aquelas sobre a configuração das instituições da nova nação. Para o mesmo período e mesmos documentos, Lucia Bastos das Neves ${ }^{10}$ estuda as semelhanças entre a cultura política dos portugueses de Portugal e dos luso-brasileiros, mostrando a íntima conexão entre a Revolução do Porto e a independência brasileira - levadas a cabo sob os mesmos ideais do iluminismo português.

Ainda nesta seara, Gladys Sabina Ribeiro, em Nação e cidadania em alguns jornais da época da Abdicação: uma análise dos periódicos O Repúblico e O Tribuno do Povo ${ }^{11}$, demonstra a influência do teórico genebrino Jean-Jacques Rousseau sobre os

\footnotetext{
${ }^{7}$ Compreendida, aqui, nos termos elaborados por Jürgen Habermas: aglutinação de indivíduos - agentes privados - que disputava com o Estado a regulação da vida social e econômica do país. Cf. Jürgen Habermas, The Structural Transformation of the Public Sphere. An inquiry into a Category of Bourgeois Society. Cambridge: Polity Press, 1996. Especialmente páginas 20-70.

${ }^{8}$ As transformações dos espaços públicos: imprensa, atores políticos e sociabilidades na Cidade Imperial (1820-1840). São Paulo: Hucitec, 2005

${ }^{9}$ Isabel Lustosa. Insultos impressos: a guerra dos jornalistas na Independência 1821-1823. São Paulo: Companhia das Letras, 2000.

10 Lúcia Maria Bastos Pereira das Neves. Corcundas e Constitucionais: a cultura política da independência (1820-1823). Rio de Janeiro: Revan: FAPERJ, 2003.

${ }^{11}$ In Entre a monarquia e a república. Imprensa, pensamento político e historiografia (1822-1889), Monica Leite Lessa e Silvia Carla Pereira de Brito Fonseca (orgs.). Rio de Janeiro: EDUERJ, 2008.
} 
seus respectivos redatores Antonio Borges da Fonseca e Francisco das Chagas de Oliveira França, conhecidos publicamente como republicanos. Sílvia Carla de Brito Fonseca, no mesmo volume, estuda os jornais republicanos e/ou federalistas publicados na Bahia entre 1831 e 1836, traçando sua relação com a Sabinada, revolta separatista eclodida em novembro de $1837^{12}$. Há ainda neste campo a tese de doutorado de Marcello Basile, que divide as correntes políticas da Corte em exaltados, moderados e caramurus e analisa a produção jornalística e formação de sociedades patrióticas patrocinadas por cada uma delas, como método para esclarecer os projetos que defendiam ${ }^{13}$.

Apesar do grande interesse no estudo dos projetos políticos veiculados pela imprensa, não existem pesquisas dedicadas a sistematizar o tratamento a ela dispensado pelo Estado, e é isso que este trabalho se propõe a fazer, por meio da análise dos debates legislativos sobre as leis que regulariam a atividade jornalística e levantamento dos atos executivos que dispunham sobre o assunto.

Isso porque o Estado também teve papel fundamental na configuração dos espaços públicos, especialmente em países nos quais sua presença normativa sempre foi forte, como é o caso do Brasil. De maneira geral, pode-se afirmar, com Michel Foucault, que "temos de deixar de descrever sempre os efeitos do poder em termos negativos: ele 'exclui', 'reprime', 'recalca', 'censura', 'abstrai', 'mascara', 'esconde'. $\mathrm{Na}$ verdade o poder produz; ele produz realidade; produz campos de objetos e rituais da verdade"14. Antonio Manuel Hespanha, no mesmo sentido, explicita o quinhão que coube ao Estado na conformação da vida social sob a influência teórica do liberalismo doutrinário:

"os direitos eram, agora, subordinados ao direito. E este, muito claramente identificado com a vontade do poder, corporizada, nomeadamente, na lei. Não tanto pela origem parlamentar desta, mas essencialmente pela sua natureza de comando, ordenador, racionalizador, curador do interesse público"15.

\footnotetext{
${ }^{12}$ Federação e república na imprensa baiana (1831-1836). In Monica Leite Lessa e Silvia Carla Pereira de Brito Fonseca (orgs.), op. cit.

${ }^{13}$ Marcello Basile. O Império em construção: projetos de Brasil e ação política na Corte Regencial. Tese de Doutorado apresentada ao Programa de Pós-Graduação em História Social, Instituto de Filosofia e Ciências Sociais, da Universidade Federal do Rio de Janeiro. Rio de Janeiro, outubro de 2004.

${ }^{14}$ Michel Foucault. Vigiar e Punir. Petrópolis: Vozes, 2000. Página 172.

15 Antonio Manuel Hespanha. Guiando a mão invisível. Direito, Estado e leis no liberalismo monárquico português. Lisboa: Almenadina, 2004. Página 7.
} 
No caso brasileiro essa assunção faz ainda mais sentido pelo fato de que aqui, ao menos durante o Império, entendia-se que o Estado deveria ter parte ativa na formação e expressão da nacionalidade e de suas instituições. A vertente anglo-saxã do liberalismo, que recusava a ingerência do poder sobre as atividades e liberdades do indivíduo, não foi politicamente relevante no Brasil, mas sim sua versão francófona, doutrinária, que ao mesmo tempo em que defendia as liberdades individuais frente aos abusos e arbítrios do governo absolutista, julgava necessário que a Nação se corporificasse no Estado. Ele deveria reunir em si os interesses nacionais e utilizar seu aparato administrativo em função de torná-los concretos. Um ideal abstrato de 'unidade espiritual' entre povo e Estado, objetivado historicamente por meio do aceite da legitimidade que tinha o parlamento em legislar, e o governo em executar suas disposições, de maneira a limitar o gozo das liberdades individuais sempre que se opusesse à fruição do bem-estar geral. Isso porque, consoante a teoria da soberania nacional,

“a vontade da nação não preexiste à vontade de seus representantes. São eles, os representantes, que criam a vontade nacional. Poderíamos afirmar: a vontade dos representantes é a vontade da nação. Isto porque a nação, como tal, é um sujeito que não pode manifestar-se, senão por seus porta-vozes, nem possui uma vontade que possa constituir-se independentemente das pessoas" ${ }^{\prime 16}$.

A representação é um conceito chave dessa estrutura. Era ela que, além de criar a legitimidade dos governantes, unificava a vontade nacional ${ }^{17}$. Não é por nada menos que nos parlamentos sempre se repetiu que ali não havia deputados das províncias, mas sim eleitos pelas províncias - eram representantes, simultaneamente, das localidades que os elegeram e de toda a nação ${ }^{18}$. Uma das conseqüências políticas deste raciocínio é que os representantes teriam independência em relação aos desejos e interesses de seus eleitores, não devendo mesmo consultar suas opiniões sobre quaisquer assuntos: a deliberação deveria ser fruto do debate parlamentar racional ${ }^{19}$. É claro que não se deve levar essas premissas às suas últimas conseqüências e julgar que, nas Câmaras de Deputados os interesses específicos dos distritos e províncias não tivessem qualquer

\footnotetext{
${ }^{16}$ Giovanni Sartori. A teoria da representação no Estado representativo moderno. Belo Horizonte: Revista Brasileira de Estudos Políticos, 1962. Citação à página 21.

${ }^{17}$ Giovanni Sartori, op. cit, página 23.

${ }^{18}$ Nesse sentido, as eleições não serviriam para criar laços entre um deputado e seus constituintes, mas sim para selecionar, dentre os locais, os mais capazes, mais aptos para desempenhar as funções do legislador. Desse modo, as eleições recrutariam uma espécie de "elite natural", servindo a propósitos mais aristocráticos do que democráticos. Sobre esse caráter das eleições, ver Bernard Manin. Los principios del gobierno representativo. Madrid: Alianza Editorial, 1998, capítulo 3.

${ }^{19}$ Hanna Pitkin. The concept of representation. Berkeley: University of California Press, 1984, capítulo 8.
} 
espaço para se manifestar; trata-se, ao contrário, de compreender essa instituição como facilitadora da negociação entre interesses regionais diversos e destes com uma 'razão de Estado' que os engloba e supera ${ }^{20}$.

O parlamento, de fato, foi uma instância política fundamental durante o século XIX. Segundo Fernanda Paula Souza Maia, ele

"cedo se iria apresentar, pelo menos do ponto de vista teórico, como garante contra qualquer tentativa de autoritarismo, salvaguardando a possibilidade de uma excessiva concentração de poderes, enquanto instrumento de controlo e fiscalização do seu exercício pelo governo e Administração"21.

A autora afirma isto em relação à experiência portuguesa, mas é possível estender o raciocínio para o Brasil. Aqui, durante o Primeiro Reinado, a Câmara foi o espaço por excelência de oposição a D. Pedro, seguida de perto pela imprensa. Suas prerrogativas garantiam-lhe poderes consideráveis para barganhar com o poder executivo: por exemplo, o orçamento e outras dotações financeiras deveriam ser necessariamente votados pelo plenário para que sua execução fosse considerada legal. Além disso, as sessões parlamentares possibilitavam a grupos minoritários ou provenientes de províncias distantes que vocalizassem institucionalmente suas demandas e descontentamentos, estimulando a ratificação de sua adesão ao Império ${ }^{22}$.

Entre as preocupações do parlamento estava regular o exercício da liberdade de imprensa. A regulamentação foi justificada, pelos deputados e pelos ministros, com a manipulação do termo 'interesse geral' de modo a identificá-lo com a manutenção da 'paz e ordem públicas', que se tornava o parâmetro dentro do qual a imprensa poderia trabalhar. De fato, foi um esforço muito grande, porque a atividade jornalística relacionava-se intimamente à formação e disputa da opinião pública, outro conceito fundamental para compreender a política do século XIX.

Nas palavras de Maria Beatriz Nizza da Silva,

"Uma das diferenças fundamentais entre o governo absolutista e o governo constitucional estava em que, enquanto no primeiro o saber político competia apenas àqueles que desempenhavam elevados cargos na administração e

\footnotetext{
${ }^{20}$ Para um estudo da Câmara dos Deputados brasileira como espaço de negociação entre interesses regionais e nacionais, ver Miriam Dolhnikoff. O Pacto Imperial. Origens do federalismo no Brasil. São Paulo: Globo, 2005.

${ }^{21}$ Fernanda Paula Souza Maia. O discurso parlamentar português e as relações Portugal-Brasil: a Câmara dos Deputados (1826-1852). Lisboa: Fundação Calouste Gulbenkian, 1992. Citação à página 13.

${ }^{22}$ Segundo Bernard Manin, o debate como meio de produzir consentimento e acordo entre interesses distintos é o que confere o caráter público às decisões tomadas num parlamento.
} 
compunham a alta burocracia do Antigo Regime, na segunda forma de governo todo cidadão precisava de instruir-se, adquirindo os conhecimentos que the permitiriam desempenhar bem o seu papel, quer como eleitor quer como representante da nação.

A essa divulgação do saber político se entregaram os autores de folhetos e os redatores de periódicos" 23 .

Este não era um saber neutro ou natural, mas as posições e projetos políticos que cada redator defendia publicamente, buscando com isso angariar apoio entre os cidadãos leitores ou apenas legitimar suas idéias por meio da exposição pública, conferindo-lhes ares coletivos. Esse caráter é esclarecido por Giovanni Sartori:

“Em seu sentido primário, uma opinião é considerada pública não apenas por ser difundida entre os públicos, como também por dizer respeito a 'coisas públicas', à res publica. Em síntese, opinião pública é antes de tudo um conceito político. Isso significa que uma opinião sobre coisas públicas é - deve ser - uma opinião exposta à informação sobre as coisas públicas. Concluindo, a opinião pública pode ser definida da seguinte maneira: um público, ou uma multiplicidade de públicos, cujos estados de espírito difusos (opiniões) interagem com fluxos de informações relativas ao estado da res publica. É claro que um estado de espírito, ou opinião, compõe-se de ingredientes muito variados: necessidades, desejos, preferências, atitudes, um sistema generalizado de crenças e outras coisas mais, conforme veremos. Mas, para serem politicamente relevantes, as opiniões em questão devem ser politicamente sensibilizadas, isto é, expostas às informações relativas a eventos ligados à sociedade política" ${ }^{24}$.

O público - entidade que ao mesmo tempo emanava diretrizes políticas que deveriam guiar a tomada de decisões por parte do governo e recebia e julgava as opiniões a respeito da condução da política - era, teoricamente, aberto a todos que dele quisessem e detivessem os requisitos necessários para isso. A igualdade dos homens dentro dos círculos de discussão, se não foi realizada, era ao menos teoricamente almejada $^{25}$. Isso permitia àqueles que participavam das discussões políticas sentirem-se parte de um público maior, ilimitado, sem que significasse estarem em posição de

\footnotetext{
${ }^{23}$ Maria Beatriz Nizza da Silva, Nova História da Expansão Portuguesa. O Império Luso-Brasileiro, (1750-1822). Direção de Joel Serrão e A. H. de Oliveira Marques. Lisboa: Editorial Estampa, 1986. Página 408.

${ }^{24}$ Giovanni Sartori. A Teoria da Democracia Revisitada. Volume 1: o debate contemporâneo. São Paulo: Ática, 1994. Citação à página 125.

${ }^{25}$ Jürgen Habermas, op. cit., página 36.
} 
igualdade com todos os outros homens: "they claimed to act as its mouthpiece, in its name, perhaps even as its educator - the new form of bourgeois representation" ${ }^{\text {26 }}$. Tal estrutura do público harmonizava com o governo dos mais capazes, pois, à semelhança dos melhores homens que eram selecionados pelas eleições para formar o corpo político da nação, existia também "una magistratura moral de la opinión, confiada a unos pocos, a "un cuerpo consagrado por la naturaleza de sus ocupaciones a enseñar y proponer los medios para hacer feliz a la patria" 27.

Desta maneira, o público era uma construção político-ideológica que se colocava, em fins do século XVIII e início do XIX, como uma alternativa à dominação absolutista, legitimando as reivindicações burguesas de participação nos negócios do governo que não cabiam na antiga organização ${ }^{28}$. Segundo Patrick Champagne,

“a “opinião pública” é, assim, uma máquina de guerra "improvisada" pelas elites intelectuais e pela burguesia de toga a fim de legitimar suas próprias reivindicações no campo político e enfraquecer o absolutismo régio (...) o problema colocado a essas elites intelectuais é somente justificar sua entrada em um jogo do qual ainda estão amplamente excluídas e minar, por todos os meios disponíveis, a legitimidade do regime político estabelecido" 29 .

Ainda que aqui não se endosse a interpretação de que o único problema das elites intelectuais burguesas era justificar suas reivindicações de participação política, essa citação é importante por frisar a importância da idéia de opinião pública como arma na luta contra o Antigo Regime. Isso porque contrariava frontalmente as prerrogativas que o sustentavam, como a da legitimidade do governo oriunda da origem divina do monarca e o segredo de Estado. O enfrentamento da primeira se dava com a luta pela representação; quanto à segunda, além da exigência de liberdade de expressão das opiniões, dizia respeito à exigência de que o Estado passasse a se comunicar com os cidadãos, publicando suas decisões e atos, de forma a permitir sua análise e crítica.

Isso não significa que os poderes estabelecidos não tenham tentado apropriar-se da opinião pública: fosse pela edição de jornais que defendessem a política ministerial, pelo controle e perseguição dos redatores oposicionistas, ou pela edição de normas que regulassem a atividade periódica, o espaço público criado pela imprensa - idealizado

\footnotetext{
${ }^{26}$ Idem, página 37.

${ }^{27}$ François-Xavier Guerra. Modernidad y Independencias: ensayos sobre las revoluciones hispanicas. Madrid; México: Editorial MAPFRE: Fondo de Cultura Económica, 1993. Citação à página 272.

${ }^{28}$ Keith Michel Baker. "Naissance de l'opinion publique”, in Annales ESC, jan-fev 1987, nº1, pp. 41-71.

${ }^{29}$ Patrick Champagne. Formar a opinião: o novo jogo político. Petrópolis: Vozes, 1996. Citação à página 48.
} 
como domínio exclusivo da sociedade civil - nunca esteve 'imune' às influências do poder estatal. Constituiu-se, dessa forma, "un système nouveau dans le cadre duquel le gouvernemment et ses adversaries entrèrent directement em concurrence, chacun faisant appel au "public", et chacun se vantant d'avoir abtenu de ce tribunal un veredict favorable" ${ }^{30}$. Naturalmente, o reconhecimento da necessidade de dirigir-se ao público e responder às suas intervenções, por parte do poder absolutista, indica que as mudanças por que passava o sistema político não poderiam ser ignoradas, nem o Antigo Regime restaurado em sua plenitude.

Retomando a citação de Maria Beatriz Nizza da Silva, é possível mapear, então, a relação que a teoria política liberal oitocentista estabelecia entre opinião pública e representação: era necessário, para a adequada participação política agora praticada pelos cidadãos, que a informação sobre as coisas públicas circulasse o mais livremente possível, assim como as discussões a seu respeito. Nas boas palavras de Lucien Jaume, “el gobierno representativo supone la fuerza de la opinión como realidad exterior a las instituiciones del Estado: el free government es un government by opinion"31.

Não se pode, contudo, ignorar que estas definições deixam de lado o caráter formativo da ação do Estado sobre a opinião e os espaços públicos, o enfoque deste trabalho. Além disso, deixam de lado também os diversos intercruzamentos existentes entre o público, os seus agentes formadores e o governo - pois é sabido que em muitos casos eram os próprios ministros e parlamentares os redatores de jornais políticos, que também liam-se mutuamente, e assim exerciam simultaneamente esses papéis, borrando a linha divisória entre sociedade civil e governo ${ }^{32}$.

De qualquer modo, não se deve perder de vista que o governo representativo apoiava-se na premissa da liberdade de expressão; se não tanto pela função de informar o governo das opiniões correntes dos cidadãos sobre quaisquer assuntos, ao menos pelo espaço privilegiado de oposição que a imprensa se tornou, e do qual os novos agentes políticos não abririam mão.

É importante também tratar do que se entende por sistema representativo brasileiro no século XIX. Segundo Bernard Manin,

\footnotetext{
${ }^{30}$ Keith Michel Baker, op. cit, página 44.

${ }^{31}$ Lucien Jaume. El liberalismo posrevolucionario: Francia e Inglaterra. in Orígenes del Liberalismo. Universidad, política, economía. Ricardo Robledo, Irene Castells e María Cruz Romeo (Eds). Salamanca: Ediciones Universidad de Salamanca, 2003. Citação à página 151.

${ }^{32} \mathrm{O}$ debate teórico sobre a distinção entre Estado e sociedade civil é imenso e muito mais complexo do que este que se apresenta. Contudo, não cabe aqui uma discussão detalhada, pois o trabalho assume o ponto de vista da produção de realidades políticas pelo Estado.
} 
"A idéia do governo representativo esteve ligada, desde o princípio, à aceitação da diversidade social. A representação foi proposta em primeiro lugar como técnica que permite o estabelecimento de um governo emanado do povo em grandes e heterogêneas nações. (...) [mesmo autores que] ressaltavam com maior insistência que o papel das assembléias era o de produzir unidade, assumiam que os representantes, eleitos por localidades e populações diversas, reconheciam nas assembléias certa heterogeneidade. Assim, sempre se considerou que o órgão representativo tinha um caráter heterogêneo e coletivo",33.

Nesses termos, a vitória do projeto constitucional-representativo no Brasil está relacionada à necessidade de conciliar diferentes elites sob um mesmo governo e território e não com a inclusão política e social de parcelas cada vez maiores da população. Aqui se optou pela representação por ser ela a maneira de conseguir alguma governança para a nova nação, como já foi explicitado.

Estas são as referências teóricas que informaram as análises deste trabalho. A discussão historiográfica que aqui falta é feita no desenrolar dos capítulos, que estão estruturados da seguinte forma.

Os três primeiros discutem a legislação dos abusos de imprensa produzida entre os anos de 1820 e 1840 e a sua implementação - ou seja, as abordagens dos poderes legislativo e executivo. $O$ primeiro resenha brevemente a legislação portuguesa sobre o assunto, a fim de demonstrar que o debate brasileiro não era anômalo em relação às outras experiências liberais, ainda que tivesse suas especificidades. A escolha pela legislação lusitana se deu por conta da similaridade das orientações liberais predominantes no Brasil e em Portugal e das constituições que as conformaram (ambas outorgadas por D. Pedro, respectivamente em 1822 e 1826).

O segundo capítulo introduz a análise da legislação brasileira, e cobre o período que vai da Revolução do Porto até a outorga da Constituição, em 1824, discutindo os decretos executivos anteriores à independência, as devassas instauradas por José Bonifácio e D. Pedro e as posições dos deputados à Assembléia Constituinte de 1823, assim como seu fechamento. O terceiro, então, concentra-se na produção legislativa inaugurada pelas sessões regulares da Câmara dos Deputados, a partir de 1826, e nas medidas executivas, até 1840, concentrando-se especialmente nos debates parlamentares

\footnotetext{
${ }^{33}$ Bernard Manin, op. cit, página 228-229.
} 
que resultaram na lei de 1830, nas disposições do Código Criminal, editado no mesmo ano, e nas orientações expedidas pela regência de Diogo Feijó sobre o tema.

O quarto capítulo aborda as discussões e medidas referentes à publicação dos trabalhos da Câmara. Além de uma exposição mais completa sobre a publicidade dos atos do governo no regime representativo, são analisadas as posições dos deputados sobre o tema, os esforços políticos e pecuniários comprometidos na empreitada da edição e publicação dos Diários e as conexões políticas e os interesses financeiros e simbólicos que se criaram com a terceirização destas tarefas para periódicos da Corte.

Por fim, o quinto capítulo apresenta um pequeno apanhado de materiais colhidos em jornais governistas e oposicionistas que versam sobre a relação entre a imprensa e a Câmara, além de alguns posicionamentos a respeito da liberdade de imprensa. 


\section{Capítulo 1}

\section{Controle da imprensa e da opinião: a legislação portuguesa}

A defesa da liberdade de imprensa inscreve-se na preocupação iluminista de eliminar da política a centralidade do segredo de Estado, característica fundamental do regime absolutista. A imprensa era peça-chave para a negação de um sistema no qual a única personalidade pública era o monarca, o que naturalizava a confidencialidade dos negócios da administração pública. Nessa nova ordem política, a legitimidade das leis vinha da racionalidade do debate público que as produzia - e, para sua existência, era imprescindível que o conhecimento dos problemas e recursos do Estado fosse acessível ao público, assim como as idéias sobre o que fazer deles.

A liberdade de imprensa foi, assim, um dos pilares do liberalismo político do século XIX - dela dependia a coerência do sistema político que se instalava e, por isso, teve de ser discutida e implementada em todos os lugares onde se pretendeu a construção de governos constitucionais representativos.

Era por meio dela que os cidadãos expressariam suas opiniões políticas e se informariam sobre a dos outros, e esse debate, como previa a tradição iluminista, levaria à verdade social. Além disso, era tida como grande fiscal do governo, devendo denunciar prontamente os desmandos das autoridades e malversações dos funcionários

públicos. Essas ‘funções' davam materialidade à idéia de opinião pública, especialmente no que diz respeito à sua compreensão como um tribunal das idéias políticas e dos atos do poder.

A vertente pedagógica, por sua vez, afirmava que os jornais eram meios muito convenientes à educação política da população inculta. Assistir ao debate conduzido por homens ilustrados esclareceria o povo sobre os mecanismos e vantagens do sistema constitucional, ensinando-o a respeitar e proteger suas instituições. A outra face dessa atribuição, condenada veementemente, era o uso possível da imprensa para provocar desordens, desobediências, e até mesmo levantes contra a ordem estabelecida. De qualquer modo, ambas revelam respeito e temor pelo potencial mobilizador atribuído aos impressos. 
Essas são características que se encontram nos discursos sobre a imprensa em ambos os lados do Atlântico. Antes de abordar o tema destes capítulos - a análise dos debates sobre a legislação que regulava a liberdade de imprensa no Brasil entre os anos da vinda da Corte e a Regência e as leis efetivamente promulgadas - a legislação portuguesa sobre o assunto é aqui brevemente resenhada com a intenção de demonstrar que o debate brasileiro não era peculiar ou isolado, embora obviamente as especificidades de um país americano escravista, de passado colonial recente tivessem enorme peso. Foi escolhido o exemplo lusitano, primeiramente, pela relação próxima existente entre as 'versões nacionalizadas' do liberalismo político nos dois países, cuja orientação para o Estado jamais foi vencida pela predominância do indivíduo, como nos países anglo-saxões. Além de serem ambas monarquias constitucionais regidas, a partir da década de 1820, por constituições praticamente idênticas (constituição outorgada por d. Pedro a Portugal em 1826 teve algumas pequenas mas importantes alterações em relação a que ele outorgou ao Brasil em 1824).

Além disso, a experiência liberal portuguesa foi fundamental para que se encorpassem as pretensões separatistas dos colonos brasileiros - como afirma João Paulo Pimenta, há certo consenso historiográfico sobre a importância crucial do nascimento do liberalismo político português para o nascimento do Brasil independente ${ }^{1}$.

\section{As leis de Portugal}

Segundo José Tengarrinha ${ }^{2}$, em Portugal, a necessidade de controle dos escritos noticiosos se apresenta para os governantes no segundo quartel do século XVI, quando começam a surgir as relações avulsas, não periódicas, discutindo a dominação espanhola. $\mathrm{O}$ autor identifica três principais fases do regime de controle e censura da expressão pública, que de maneira nenhuma podem ser consideradas resultado de uma evolução em sentido inequívoco.

Num primeiro momento, as ações de controle e repressão foram exercidas tanto pelo Desembargo do Paço quanto pelo Santo Ofício e pelos ordinários (arcebispos e

\footnotetext{
1 João Paulo G. Pimenta. A independência do Brasil e o liberalismo português: um balanço da produção acadêmica, em Revista de História Ibero-Americana, vol. 1, número 1, 2008.

2 José Tengarrinha. Da liberdade mitificada à liberdade subvertida: uma exploração no interior da represssão à imprensa periódica de 1820 a 1828. Lisboa: Edições Colibri, 1993.
} 
bispos) nas suas respectivas dioceses. Por determinação da lei de 4 de dezembro de 1576, a aprovação dessas três instâncias tornou-se obrigatória para que um escrito pudesse circular. Nesse esquema de atribuição de poderes, tanto Estado quanto Igreja arrogavam-se do direito de censura, dividindo entre si a tarefa. Esse compartilhamento de prerrogativas acontecia no contexto da grande ofensiva eclesiástica da contrareforma, que seria combatida em prol do poder secular durante a administração pombalina (1750-1777).

O segundo regime de censura é instalado pelo decreto de 5 de abril de 1768, e reunia a censura numa única entidade, a Real Mesa Censória. Por esse motivo, é considerado pelo autor uma das mais significativas medidas de centralização do poder régio: "Unificando o comando da censura, esta convertia-se num poder a serviço do Estado centralizado, ao ponto de os censores terem passado a receber a denominação de 'régios'.”3. Além disso, pode-se acrescentar que o serviço de censura torna-se passível de certa especialização, contando com funcionários exclusivos para a tarefa.

Outro mecanismo de controle implementado pelo decreto é a imposição da obrigatoriedade de aprovação da Coroa para a instalação de impressoras e venda de livros.

Esse modelo, no entanto, teve vida curta: em 21 de junho de 1768, uma Carta de lei institui uma tentativa de conciliação entre os dois regimes precedentes, revelando uma reação da Igreja contra a perda de sua prerrogativa censória. A composição da Mesa passa a contar com teólogos, e mesmo o presidente deveria ser, obrigatoriamente, um eclesiástico. No entanto, este se revela um compromisso precário, que não resiste à radicalização religiosa do reinado de D. Maria I (num momento de regência informal de D. João), e é extinto pela Carta de Lei de 17 de dezembro de 1794, que faz voltar ao primeiro regime.

Durante o Reformismo Ilustrado português, as preocupações da censura podiam ser divididas em duas frentes: aquela contra os jesuítas, vistos como agentes contrários ao esforço secular modernizante (conservador e regalista, evidentemente), e a que tinha como alvo os iluministas radicais franceses, defensores do ateísmo e da soberania popular.

A submissão do texto às três instâncias censórias (Desembargo do Paço, Santo Ofício e bispos locais) trazia um obstáculo além daquele óbvio que era a possível

\footnotetext{
${ }^{3}$ Idem, página 16.
} 
proibição à publicação: a demora da análise tripla era capaz de estrangular o movimento da imprensa periódica, e os problemas de circulação assim impostos levavam diversos editores e impressores a burlar o sistema censor. Para Tengarrinha, "É então que adquirem papel mais importante os regulamentos ou regimentos preocupados já não apenas com a matéria censurável, mas sobretudo com os mecanismos do exame" "4 Assim é entendido o alvará de 30 de julho de 1795, que estabelecia que cada uma das instâncias deveria contar com um censor fixo, encarregado de julgar e qualificar em tempo oportuno os papéis periódicos, para que não fossem muito prejudicados. Fica evidente o movimento em direção à burocratização, na forma de regulamentos oficiais, do ‘serviço público' que era a censura.

Mesmo no contexto do Antigo Regime, então, certas pressões não podiam ser ignoradas, mas sim negociadas. A medida citada tentava garantir a eficácia da censura, que deveria se adaptar às exigências de celeridade características do fenômeno de comunicação que então surgia, por não poder simplesmente fazer frente aos editores e jornalistas, acabando por revelar a incapacidade da instituição em se adaptar às transformações políticas e econômicas do fim do século XVIII.

Essas, segundo as análises de liberais coevos, referiam-se ao desenvolvimento de forças pouco afeitas à dominação do Estado nos moldes do Antigo Regime, como as relações de mercado, os novos parâmetros de trocas internacionais e também de comunicação social, que já estava baseada na circulação mais ou menos ampla de opiniões e informações e, assim, era tida por responsável pela emergência de uma complexa 'verdade' social. Desse modo, era necessário garantir sua liberdade de circulação, pois dela dependia não só o direito individual à opinião, mas a materialidade das idéias da sociedade e a mediação entre os valores dos políticos e dos cidadãos ${ }^{5}$.

Em Portugal, as pressões pelo estabelecimento de novos padrões para a relação entre Estado e sociedade civil desembocariam, em 24 de agosto de 1820, num movimento militar apoiado pela burguesia ilustrada da cidade do Porto, que proclama uma Junta Governativa, incumbida de convocar eleições para as Cortes, a fim de discutir uma Constituição para o reino. O movimento liberal se inspirava diretamente nos acontecimentos espanhóis, onde há pouco também acontecera um levante

\footnotetext{
${ }_{5}^{4}$ Idem, página 17.

5 Antônio Manoel Hespanha. Guiando a mão invisível. Direito, Estado e leis no liberalismo monárquico português. Lisboa: Almenadina, 2004. Página 97.
} 
constitucional $^{6}$, e utilizaria a lei fundamental espanhola, então considerada a mais democrática, como base de seus trabalhos. Segundo Manoel Hespanha, o movimento atribuía à palavra constituição um novo significado: até então, sua acepção jurídica era restrita à "lei do príncipe", ou da autoridade eclesiástica; a partir desse momento, passava a designar, ao mesmo tempo, a garantia dos direitos individuais do cidadão e a organização formal dos poderes do Estado e de seus limites ${ }^{7}$.

O liberalismo português, a exemplo de todos os outros, defendia como direito natural a liberdade de expressão do pensamento; no entanto, eram grandes as controvérsias sobre os limites que deveriam ser impostos ao seu exercício. Tampouco este é um dilema exclusivo; por mais variados que tenham sido os graus de liberdade concedidos à imprensa em diversos países, sempre houve debates sobre a sua extensão, e era consenso de que deveria ser regulado de alguma forma, mais ou menos frouxa.

Segundo Tengarrinha, a discussão sobre a amplitude da liberdade de imprensa estruturava-se entre aqueles que afirmavam que a nação portuguesa não estava preparada para a liberdade, e fatalmente dela faria mau uso, daí derivando a necessidade de manter a censura prévia, e os que acreditavam que a manutenção desta deformaria de tal maneira o pressuposto da livre expressão que se gerariam males muito maiores do que os decorrentes de eventuais abusos. Como se verá adiante, essa polarização não se observa nos debates sobre o assunto no Brasil, onde a discussão já é iniciada com a negativa unânime à censura prévia.

Outra polarização identificada pelo autor, já dentre os advogados do fim da censura, é aquela mobilizadora, de um lado, daqueles que, mesmo reconhecendo o papel fundamental da livre imprensa para o novo regime, percebiam-na como potencial e perigosa inimiga, sendo por isso necessário mantê-la nos limites de uma "exata justiça" e, de outro lado, uma corrente defensora de ampla liberdade de imprensa em matérias políticas por acreditar que ela "não atacaria o edifício social. O sistema constitucional assumia [para estes], assim, a dimensão de Dogma político, identificado com o conceito abstrato de Estado, como organização suprema da sociedade" ${ }^{\prime 8}$. Nenhuma das correntes, então, permitiria que a imprensa carregasse debates ou proposições que contradissessem o sistema político escolhido e pactuado pela nação, baseadas, respectivamente, em

\footnotetext{
${ }^{6}$ Inclusive, a revolução na Espanha daria garantias aos revoltosos portugueses de que não sofreriam represálias externas vindas desse país. Cf. Valentim Alexandre. Os sentidos do Império. Questão nacional e questão colonial na crise do Antigo Regime português. Porto: Edições Afrontamento, 1993.

${ }^{7}$ Antônio Manoel Hespanha, op. cit, página 40.

${ }^{8}$ Idem, página 28.
} 
prospecções do futuro pessimistas e otimistas; a primeira acreditava na possibilidade de os jornalistas voltarem-se contra o governo e sistema político que possibilitavam sua existência, e por isso defendia maior controle sobre as publicações, por meio de legislação que coibisse e punisse severamente os crimes de abuso da liberdade de imprensa. A segunda posição relaciona-se com uma corrente liberal que defenderia o papel pedagógico da imprensa política, a instruir o povo dos benefícios do sistema constitucional e, identificando nos redatores políticos aliados importantes desse projeto civilizador, não acreditavam que seriam por eles 'traídos'.

Os artigos 8, 9 e 10 das Bases da Constituição são o resultado das discussões das Cortes sobre o assunto, e revelam novamente a imperiosa necessidade de negociação e acomodação entre interesses e concepções conflitantes. Enquanto os dois primeiros estabelecem a liberdade absoluta de expressão dos pensamentos, independente de censura prévia, desde que fosse respeitada a ordem pública, o último admite que os textos relativos a matérias religiosas ("dogma e moral") estariam sujeitos à censura dos bispos, que contariam com a ajuda do governo para castigar os culpados de abuso. Para Tengarrinha,

"o poder liberal, formalmente defensor do mais amplo conceito de liberdade de imprensa, lhe introduziu limitações legais e, na prática, em grande medida o denegou, mesmo para além da justificação da necessidade de combate aos absolutistas",9.

Essa observação, contudo, não leva em conta que, para o liberalismo, é dever do Estado regular, por meio de legislação elaborada por representantes eleitos, o usufruto das liberdades individuais, de modo a garantir a supremacia do interesse público. A liberdade de imprensa, nesse sentido, estaria subordinada à manutenção da ordem pública, constitucional-representativa que, muitas vezes e até propositalmente, confundia-se com o próprio governo, o que justificaria as limitações impostas à ação tanto de absolutistas quanto dos liberais mais radicais.

Há de se ter em mente, também, que mesmo adotando alguns discursos e medidas liberais, os homens do tempo ainda estavam impregnados de idéias e visões de mundo referentes ao sistema anterior, e durante algum tempo haveria essa dúbia convivência entre preceitos liberais e absolutistas. Além disso, trata-se de um movimento liberal que, eclodido trinta anos após a Revolução Francesa, pôde duvidar

\footnotetext{
${ }^{9}$ Idem.
} 
de um liberalismo radical e revolucionário, e se apropriar, sem o Terror, das concessões feitas pela Restauração. Ainda assim, é possível afirmar que existia certo descompasso entre a organização política do Estado estabelecida pela Constituição de 1822, considerada, em grandes linhas, muito liberal ${ }^{10}$, e suas disposições relativas à liberdade de expressão, muito mais restritivas do que leis de países regidos por constituições menos "democráticas", como o Brasil.

Apesar do determinado no decreto das Bases da Constituição, em 21 de setembro de 1820 uma portaria nomeia uma Comissão de Censura prévia. O argumento dos dirigentes liberais era a necessária precaução contra eventual transformação da imprensa em instrumento de luta contra o sistema constitucional. No entanto, os problemas que antes afligiram a administração do Antigo Regime continuaram a existir: faltavam meios para o trabalho dos censores, desde instalações adequadas até funcionários suficientes. Nas palavras de Luís Carlos Villalta, tratava-se de uma "máquina burocrática lenta, dotada de critérios desiguais e constituída por órgãos com jurisdições muitas vezes superpostas, incumbida de várias tarefas prevenir, interditar, reprimir - [que] defrontava-se com o dinamismo editorial e do comércio livreiro e, ademais, com as ousadias dos leitores, nem sempre obedientes em relação às proibições legais"11.

Tornando a situação ainda mais complexa, foram grandes as dificuldades impostas aos censores liberais pelo próprio aparelho de Estado, quadros remanescentes (e descontentes) da antiga administração, que ainda tinham condições de criar empecilhos e forçar conflitos de jurisdição, o que forçosamente atrasava a inspeção dos impressos. Tudo isso contribuía para que proliferassem jornais e folhetos que circulavam sem licença da Comissão, mesmo após a promulgação das instruções de 11 de novembro de 1820, que responsabilizavam impressores, encadernadores e livreiros por tal falta; dessa forma, o esforço para um controle intensivo favoreceu a liberdade de imprensa de facto.

Além dessas dificuldades, Tengarrinha afirma que a Comissão enfrentava grandes problemas pelo fato de não terem sido esclarecidos os critérios políticos que

\footnotetext{
${ }^{10}$ Especialmente pela grande predominância conferida ao poder legislativo (unicameral, detentor privado da iniciativa legislativa e eleito diretamente), representante da Nação (por sua vez, detentora exclusiva da soberania) em detrimento do poder executivo do monarca.

${ }^{11}$ Luís Carlos Villalta. Censura literária e circulação de impressos entre Portugal e Brasil (1769-1821), in Dutra, Eliana de Freitas e Mollier, Jean-Yves (orgs.). Política, nação e edição: o lugar dos impressos na construção da vida política no Brasil, Europa e Américas nos séculos XVIII-XX. São Paulo: Annablume, 2006. 624 págs.
} 
deveriam guiar suas decisões. Sendo deixada a definição em suas mãos, tomou como seus inimigos os liberais radicais, acusados de responsáveis pela agitação da opinião pública, e não os defensores do Antigo Regime. Eram quatro as principais preocupações da censura: perseguição e ameaça aos jornais que não cumpriam fielmente as instruções de 11 de novembro (especialmente a obrigatoriedade da rubrica do censor em todas as páginas do impresso), o que pode ser entendido como uma sinalização de que a fuga à censura não seria tolerada; impedir os ataques ao governo por sua tibieza ou moderação, (demonstrando a tendência, observada pelo autor, da escolha, pelos censores, de perseguir especialmente os redatores liberais); censura aos ataques pessoais a figuras importantes do regime (mais violentos quando partiam da imprensa antiliberal); e proibição de notícias alarmistas sobre a situação externa, entendidas como de intenção desestabilizadora.

Essas linhas de atuação da censura correspondem, grosso modo, ao embate verificado pelo autor entre os periódicos - aqueles que atacavam as Cortes, defendiam o Trono e o governo, normalmente exageravam as ameaças externas e acusavam e denegriam os dirigentes liberais, e os que defendiam a superioridade das Cortes em relação ao governo do monarca e desferiam ataques pessoais mais comedidos. Essa separação não quer dizer que estivessem sempre em territórios diferentes e demarcados; pelo contrário, muitas vezes se confundiam entre si, o que se mostrava vantajoso para as autoridades censoras, pois podiam ir contra uns e outros, indistintamente, em nome da nova ordem. A falta de um plano claro e geral a ser seguido pela Comissão de Censura é o que, para Tengarrinha, dava o tom de sua atuação, pautada pela atenção a "questões pontuais e circunscritas, relacionadas diretamente com a estabilidade política"12.

A primeira lei de liberdade de imprensa de Portugal foi elaborada pelas Cortes e posta em vigor pelo decreto de 4 de julho de 1821. No seu preâmbulo se reafirmavam os preceitos liberais relativos à matéria:

"O espírito do governo constitucional consiste na existência de um congresso representativo onde se delibere e discuta publicamente sobre os seus principais interesses. Os objetos de utilidade geral passam daí também a ser examinados e discutidos entre os cidadãos; e seria uma notável contradição negar-se-lhes o exercício daquele direito, que se tornou como base para a formação do governo,

\footnotetext{
12 José Tengarrinha, op. cit, página 39.
} 
de maneira que repugna a existência de um tal governo com a não existência da liberdade política da Imprensa" ${ }^{\prime 13}$.

Está aí elencada com clareza a relação entre governo representativo, publicidade e liberdade de imprensa: os deputados eleitos teriam de levar em conta, no momento de construção do interesse nacional - que consistia no debate público - as considerações que seus concidadãos tivessem a oferecer. O conhecimento, circulação e debate destas opiniões só poderia acontecer com o auxílio de uma imprensa livre e dedicada à 'utilidade geral'.

A menção à liberdade política da imprensa deve-se, como visto, à restrição que os textos religiosos haveriam de sofrer, pelo acordado que os bispos seriam responsáveis pela sua censura prévia.

A Constituição, depois de definitivamente aprovada pelas Cortes em 1822, tratava da matéria em seus artigos $7^{\circ}$ e $8^{\circ}$ :

“Art. 7: A livre comunicação dos pensamentos é um dos mais preciosos direitos do homem. Todo o português pode, conseguintemente, sem dependência de censura prévia, manifestar suas opiniões em qualquer matéria, contanto que haja de responder pelo abuso desta liberdade nos casos e pela forma que a lei determinar.

Art. 80: As Cortes nomearão um tribunal especial para proteger a liberdade de imprensa e coibir os delitos resultantes do seu abuso, conforme a disposição dos $\operatorname{artigos} 177^{\circ}$ e $189^{\circ}$.

Quanto, porém, ao abuso que se pode fazer desta liberdade em matéria religiosa, fica salva aos bispos a censura dos escritos publicados sobre dogma e moral, e o governo auxiliará os mesmos bispos, para serem punidos os culpados.

No Brasil haverá também um tribunal especial como o de Portugal" ${ }^{\text {"14. }}$

Pelo texto da lei, eram considerados abusos da liberdade de imprensa aqueles escritos que versassem contra a religião católica romana (caso de negação de um ou todos os dogmas definidos pela Igreja, estabelecimento de dogmas falsos, blasfêmia ou zombaria), contra o Estado (exortação à rebelião ou à desobediência, ataque à forma de governo representativo, infâmia ou injúria ao Congresso nacional ou ao chefe do poder executivo), contra os bons costumes (ataque direto à moral cristã, publicação de

${ }^{13}$ José Tengarrinha. História da imprensa periódica portuguesa. Lisboa: Caminhos, 1989. Citação à página 129.

${ }^{14}$ Idem, página 130 , nota 3. 
imagens ou escritos obscenos), contra os particulares (imputação a pessoa ou corporação de qualquer fato criminoso que motivaria processo judicial, imputação de vícios ou defeitos que os expusessem ao ódio ou desprezo públicos). As penas fixadas para tais crimes eram a detenção, que ia de cinco anos (para crimes em primeiro grau contra o Estado) a um (negação do dogma cristão), e a multa pecuniária, estabelecida entre 600.000 réis, para o mesmo crime de ataque ao Estado, e 20.000 réis, para os abusos contra os bons costumes.

Era prevista a inocência das acusações contra corporações e particulares caso se provasse os crimes imputados, se fossem contra o Estado, ou dissessem respeito a abuso de poder praticado por funcionário público, e também nos casos em que o fato imputado estivesse julgado ou provado por juízo anterior, quando o fato interessasse ao público ou a particular, permitindo, desta maneira, que a imprensa efetivasse seu papel de fiscalizadora do poder público.

Os responsáveis pelos impressos, a priori, seriam o autor ou editor e, na sua ausência, o impressor. No caso de impressos de países estrangeiros, o livreiro ou o "publicador".

Finalmente, a lei previa a instituição de dois corpos de júri para as causas de abuso da imprensa: os conselhos de juízes de fato (jurados) e um tribunal de recurso, eleito pelas Cortes, e denominado Tribunal especial de proteção da liberdade de imprensa. Além de julgar as apelações, este tribunal especial deveria encaminhar à câmara as dúvidas de aplicação da lei de abuso da imprensa e também apresentar a ela, no início de cada ano, documento que informasse a situação da liberdade de imprensa, os obstáculos que a ela se interpusessem e os abusos que necessitassem de correção.

Os juízes de fato eram considerados essenciais para que a liberdade de imprensa se efetivasse, pois "Os julgamentos da liberdade de imprensa, assim, não ficavam dependentes quer das vias administrativas, quer do aparelho judicial, conservador" Por isso mesmo, sofreram com a resistência interposta pelo governo, pelos juízes de direito e corregedores das comarcas, e, assim sendo, Tengarrinha afirma que a maior parte dos conselhos de jurados não funcionou.

O Tribunal especial tampouco foi bem sucedido em suas atribuições, pois não se garantiram os meios formais e materiais para sua constituição. A grande quantidade de

\footnotetext{
${ }^{15}$ José Tengarrinha. Da liberdade subvertida à liberdade mitificada. op. cit, página 41 .
} 
dúvidas a respeito da aplicação da lei, que não eram prestamente sanadas pela Câmara, lhe emperrava o funcionamento. Por fim, também foi boicotado pelos juízes de direito.

A promulgação da constituição não desanimou o partido absolutista, encabeçado por D. Miguel e sua mãe, a rainha Carlota Joaquina, que assumem a oposição ao governo constitucional de D. João. Ao longo do ano de 1822, as disputas jornalísticas se intensificam, encorajadas pela regulação da atividade. Apesar da crescente agressividade das folhas absolutistas, segundo Tengarrinha as principais linhas de conflito situavam-se ainda dentro do campo liberal, em torno da profundidade e ritmo das reformas. Uma ala mais moderada, apoiada pelo Governo monárquico, argumentava que deveria haver harmonia do poder legislativo com o executivo e não o contrário, enquanto a ala radical defendia maiores poderes para o Congresso, derivando a legitimidade do governo mais da ligação com o povo do que com o monarca. A ênfase na soberania nacional era o principal motivo das perseguições movidas pelo governo contra os jornalistas radicais.

A complementar a ação do 'partido' absoluto, vinha o fato de que o equilíbrio sobre o qual se impunha a Constituição era instável; mesmo os constitucionalistas defendiam que fosse reformada, por ser comum a opinião de que ela não contava com as condições políticas necessárias para se manter em vigor ${ }^{16}$.

Em 1823, a ofensiva absolutista é de tal amplitude que já não pode ser ignorada, e "desencadeia-se, então, a grande vaga repressiva sobre os jornais absolutistas"17 ${ }^{\text {Em }}$ abril, militares partidários do governo absoluto insurgem-se contra a o governo de Lisboa na Vila Franca de Xira, sob comando de D. Miguel. No fim do mês, D. João assume o comando da revolta, exilando o filho; em maio, o rei declara que as instituições em voga eram "incompatíveis com a maior parte da monarquia"18; ainda assim, repudiando o absolutismo, anunciava a modificação da constituição vigente. Diante disso, o parlamento sente-se coagido e interrompe seus trabalhos - logo é dissolvido pelo rei, que aproveita o momento para revogar definitivamente a constituição, e assim encerra-se a primeira experiência liberal portuguesa ${ }^{19}$.

Em junho, é nomeada uma junta encarregada de preparar uma nova Constituição, que conciliasse as novas idéias políticas com a tradição regalista de

\footnotetext{
${ }^{16}$ Antonio Manoel Hespanha, op. cit, página 75.

${ }^{17}$ Idem, página 50.

${ }^{18}$ Antonio Manoel Hespanha, op. cit, página 90.

${ }^{19}$ Valentim Alexandre. A desagregação do Império: Portugal e o reconhecimento do Estado brasileiro (1824-1826). Análise Social, vol. XXVIII (121), 1993 (2º), pp. 309-341.
} 
Portugal; seis meses depois, alguns projetos lhe tinham sido enviados, mas suas atividades estavam suspensas. É então que o rei recebe, do presidente da comissão, o conselho de que não se publicasse constituição alguma e que fossem convocadas as antigas Cortes. Em 4 de junho de 1824, a junta é dissolvida e é proclamada uma Carta de Lei convocatória ${ }^{20}$. Nesse documento,

"Tirando partido desta ambiguidade, que procuravam acomodar a constituição tradicional a certas idéias modernas - como a da soberania nacional - ou, pelo menos, de governo representativo -, o rei resolve 'declarar em seu pleno vigor a antiga constituição política', convocando 'os três estados do reino', a fim de que estes lhe apresentem 'nos capítulos e consultas, na forma antigamente praticada, segundo as suas regalias e privilégios, o que convier a cada um dos braços dos mesmos estados, e for a bem do comum dos meus povos, engrandecimento da monarquia'; mas compromete-se ainda - coisa que também não fazia parte da constituição tradicional, ao 'estabelecimento de períodos certos e determinados para as sucessivas reuniões das mesmas cortes'."21

A ambigüidade a que se refere Hespanha é a consideração (oportunista) do monarca de que as antigas Cortes constituíam a verdadeira representação nacional, pois nelas o povo era representado por seus "procuradores" nobreza e clero. Essa manobra teórica, para o autor, é sintoma da necessidade que tinha o discurso contrarevolucionário de incorporar elementos modernos para conseguir se impor politicamente.

Com a restauração da antiga constituição da monarquia, a censura prévia é reintroduzida formalmente. A estratégia adotada pelo governo era a de estrangular os principais centros e meios difusores do pensamento liberal, e para tanto estruturou sua atuação em três planos.

Para vigiar os movimentos dos jornalistas liberais que permaneceram em Portugal (uma vez que o trabalho de acabar com seus periódicos já tinha sido feito), foi eficaz a separação da Intendência Geral da Política do Ministério da Justiça, pois garantiu celeridade ao aparelho repressivo e, "estancada a corrente do Reino, a ameaça maior vem do estrangeiro" 22 - o perigo constitucionalista vinha, então, de Londres, Bajadoz e outros lugares da Espanha. O segundo plano de repressão foi o controle da

\footnotetext{
${ }^{20}$ Idem, páginas $81-82$.

${ }^{21}$ Idem, página 83 .

${ }^{22}$ José Tengarrinha. Da liberdade subvertida à liberdade mitificada. o $p$. cit, página 55.
} 
importação de impressos e a instituição de pesadas penas para os que lessem ou distribuíssem tais jornais.

A repressão do jornalismo periódico fez proliferar os panfletos, volantes e pasquins, meios mais importantes de propaganda e agitação políticas do que de debate ideológico, que apareceram em vários pontos do país insurgindo-se contra a queda da Constituição. Contra estes, são tomadas medidas de controle sobre as tipografias e prelos portáteis, que se haviam multiplicado durante o triênio constitucional, e a Imprensa Régia reassume os privilégios de impressão. Mas a militância constitucionalista não se deixa imobilizar, e cresce a importância dos pasquins, agora manuscritos e afixados em locais de grande movimento, capazes de causar grande comoção popular, e também das volantes, proclamações breves, manuscritas ou impressas clandestinamente. Normalmente, os autores desses manifestos não conseguiam ser identificados pelas autoridades.

D. João VI morre em 10 de março de 1826, sem que tivessem acontecido as reuniões previstas das Cortes tradicionais. Como se sabe, D. Pedro havia abdicado de seus direitos ao trono português em favor de sua filha, D. Maria da Glória. Ainda nesse ano, nomeia como regente a irmã Isabel Maria e outorga a Constituição, por meio da Carta de 1826. Num esforço de conciliação com o irmão Miguel, em 1827 D. Pedro contrata que se case com a futura rainha e lhe delega todos os poderes do reino, mediante o juramento da Constituição. No ano seguinte, D. Miguel regressa de Viena (onde estivera desde que fora exilado pelo pai), jura fidelidade ao irmão e assume o governo do reino; menos de um mês depois, revoga a constituição, dissolve o parlamento e convoca os Estados Gerais, retomando a Carta de Lei da monarquia antiga de 1824.

A Constituição de 1826 vigorou durante 84 anos, com algumas interrupções. A primeira foi durante a insurreição miguelista (1828-1834), apesar de ainda estar virtualmente em vigência durante todo o período, e voltar a ser aplicada em 1829, com a nomeação, por D. Pedro, de órgãos para o governo de Portugal. Os lapsos seguintes são referentes à vigência da constituição de 1822 (1836-1838) e da de 1838 (1838-1842). Dessa forma, a constituição de 1826 foi aplicada durante as regências de Isabel Maria (1826-1828) e de D. Pedro (1832-1834) e a partir de 1842 até o fim da monarquia 
portuguesa $^{23}$. A descontinuidade de sua aplicação explica a grande alternância entre os regimes da liberdade de imprensa que se verão a seguir.

Hespanha assinala a influência marcante de Benjamin Constant nessa constituição. Testemunha da Revolução Francesa e do Terror, defendia uma organização política que, ao mesmo tempo em que não fosse uma volta ao Antigo Regime construísse instituições que limitassem a soberania popular, evitando que o exercício do poder pela 'maioria' degenerasse em outro tipo de absolutismo, e essa manifestação do liberalismo foi a mais difundida na Europa continental ${ }^{24}$. Nas suas palavras,

"em Portugal, o liberalismo espiritualista de Alexandre Herculano, preferindo a liberdade à democracia participativa, subordinando a participação política à "racionalidade" e opondo-se radicalmente ao governo do maior número, é, porventura, a elaboração mais nítida do modelo ideológico do cartismo" ${ }^{25}$.

Em outras palavras, o liberalismo doutrinário, orientação política predominante em Portugal, colocava-se contra a concepção de soberania popular, com toda a implicação democrática que ela trazia, especialmente a questão da vitória da maioria sobre as 'leis sociais objetivas'. Esta corrente entendia, ao contrário do liberalismo político saxão, que o Estado deveria, por meio de suas instituições, depurar as leis que já regiam a sociedade e racionalizá-las, submetendo toda a Nação a essa 'vontade geral': "o governo transforma-se, assim, num resumo da sociedade, mas num resumo racional, ou seja, que tenha 'a inteligência das necessidades gerais'.,26.

É dessa forma que se justificam os limites estabelecidos para o usufruto das liberdades individuais, entre elas a de expressão. No entanto, um aspecto específico da teoria liberal-representativa complica a prática política em relação à liberdade de imprensa. Os liberais doutrinários inspiradores da mesma legislação - Benjamin Constant e os ideólogos franceses, especialmente François Guizot - eram defensores de mais ampla liberdade de imprensa, necessária, como se viu, à circulação de idéias e opiniões que acabariam por sedimentar valores e opiniões 'gerais'. Pode-se conjecturar que, defrontados com a tarefa de manter a ordem e o governo do país, os liberais portugueses (e também franceses e brasileiros) tendessem a encarar a imprensa de

\footnotetext{
${ }^{23}$ Idem, página 118.

${ }^{24} \mathrm{E}$, como se sabe, também a constituição brasileira de 1824 fora marcadamente influenciada por suas teorias, especialmente no que dizia respeito à restrição dos direitos políticos, exercidos apenas pela parcela da população que reunisse o mérito necessário para tanto, e à existência do poder moderador.

${ }^{25}$ Antonio Manoel Hespanha, op. cit, página 95.

${ }^{26}$ Idem, página 105.
} 
oposição mais como um veículo da discórdia e desunião do que como promotor da unidade sentimental da nação, uma possível explicação para a perseguição perene que contra ela empreenderam - para além, é claro, das explicações mais imediatas relacionadas ao contexto e às alianças políticas de cada momento específico.

O último período analisado por Tengarrinha, em seu trabalho sobre a liberdade de imprensa em Portugal, inicia-se justamente em 1826, com a outorga da Carta Constitucional por D. Pedro IV, e se encerra em 1828, com a restauração do absolutismo por D. Miguel. A escolha de finalizar a análise num momento de grande restrição à circulação de impressos certamente contribuiu para o tom pessimista da análise. Segundo o autor, a ala liberal agora se apresentava mais coesa, com o apagamento dos radicais, então alinhados aos conservadores, em oposição aos realistas, ainda identificados com o absolutismo.

$\mathrm{Na}$ imprensa, a questão central do debate político era a legitimidade dos direitos à Coroa de Portugal. Os realistas afirmavam que, com a outorga da constituição, D. Pedro perdera sua legitimidade como monarca, enquanto os liberais batiam-se pelo cumprimento desta - o que se tornava cada vez mais difícil, dada a crescente influência dos realistas na administração central e outros postos-chave. No relativo à legislação dos abusos da imprensa, como não havia lei complementar a especificar seu cumprimento, manteve-se, na prática, a censura prévia. É só em 1828 que começam os debates parlamentares a esse respeito.

Mesmo o governo liberal do período limitou a circulação dos jornais, por meio de imposições fiscais; o método mais eficaz, e invocado diversas vezes, era mesmo a suspensão das garantias constitucionais, pois o número de censores não era suficiente para dar conta do recrudescimento do movimento jornalístico, e as intervenções da polícia prestavam-se a suprimir tais insuficiências. Mesmo com a recorrência a atos extraordinários, não se deixou de implantar medidas que visavam o aumento da eficiência da censura, como a nomeação de novos censores e a introdução de novas normas de funcionamento da Comissão: relaxaram-se as exigências para que um periódico pudesse ser impresso, bastando-lhe apenas uma assinatura (não mais em todas as páginas), e dividiram os censores em turnos alternados.

O governo também expediu, secretamente, instruções de procedimento aos censores. Embora fossem dúbias e insuficientes, apontavam para certa prioridade na defesa da ordem constitucional. No entanto, os censores eram receosos de 
comprometer-se politicamente com "um presente tão incerto",27, nas palavras de Tengarrinha, e por isso evitavam autorizar escritos favoráveis à ordem constitucional.

De certa maneira, estavam corretos. Ao crescimento da imprensa absolutista e liberal, sucedeu-se, em julho de 1827, a mais ampla operação repressiva do período, e logo cairia novamente o regime constitucional pelas mãos dos miguelistas. A nova suspensão de garantias e o fortalecimento da censura inviabilizavam os jornais liberais; num segundo momento, a repressão se volta contra os censores que permitiam que saíssem tais publicações. Com o restabelecimento de um regime absoluto, em 1828, a censura volta a ser exercida pelo Desembargo do Paço, e se instauram perseguições intensas a jornalistas, que eram inclusive condenados à pena de morte ${ }^{28}$.

Após abdicar do trono brasileiro e seguir para a Europa a fim de reconquistar o trono português para o governo constitucional de sua filha Maria, D. Pedro (agora IV) assume a regência de Portugal em 1832, travando uma guerra civil contra o irmão e seus partidários absolutistas, vencendo em 1834 e normalizando a aplicação da Carta Constitucional de 1826. Apesar disso, sua regência não baniu a censura prévia. Mesmo considerando nulos todos os atos emanados por D. Miguel sob o título de Regente ou de Rei, acabando assim com as ordens que transferiam para o Paço a censura, em novembro de 1833 é publicado um decreto que nomeava os nove censores, responsáveis pela guarda da ordem pública no que dizia respeito à imprensa, enquanto não se estabelecesse definitivamente o juízo por jurados. Foi somente pela portaria de 22 de dezembro de 1834 que se instaurou a liberdade de imprensa em Portugal. Ela prescrevia a censura prévia e regulava as condições de circulação das obras sem grandes alterações em relação à lei de 1821.

Até o fim da década, não haveria mais suspensões formais das garantias constitucionais, nem seria ressuscitada a censura aos periódicos políticos. O que não significa dizer que escrever e fazer circular um jornal tenha se tornado uma tarefa mais fácil. Continuaram a ser interpostas diversas barreiras cujo fito era embaraçar a imprensa periódica, ainda que disfarçadas. É o caso do aumento do porte dos jornais e da exigência de altas quantias para que fosse obtida a permissão de abrir uma empresa. Outro obstáculo da maior importância era a dificuldade crescente com a expedição e os portes; o governo chegou a ordenar aos Correios que não dessem expediente às folhas oposicionistas, o que impedia sua leitura fora do centro em que foram impressas. Um

\footnotetext{
${ }^{27}$ José Tengarrinha. Da liberdade subvertida à liberdade mitificada. op. cit, página, página 67.

${ }^{28}$ José Tengarrinha, História da Imprensa Periódica Portuguesa, op. cit, página 142.
} 
decreto de 22 de abril de 1834 isentava apenas o Diário do Governo dos portes do correio. Outras vezes, eram os administradores dos conselhos que, por iniciativa própria ou indicação do poder central, liam os jornais antes de o correio os distribuir pela sua circunscrição e eliminavam os que, em sua opinião, continham matéria subversiva ${ }^{29}$. A existência de tamanhos empecilhos estabelecidos por leis secundárias evidencia a debilidade do plano liberal português, que não contava com o apoio do "espírito público" para consolidar-se como política dominante.

Segundo a interpretação de Tengarrinha, nessa altura a intenção do governo já não era apenas prejudicar os jornais da oposição; para o autor,

"O objetivo era mais fundo e ambicioso: criar dificuldades, sobretudo de ordem econômica, a todos os jornais, o que os obrigaria a elevar os preços e, assim, serem lidos apenas pelas camadas mais abastadas da população, conservando-se as mais baixas à margem da informação, para aumentar a ignorância e apatia políticas. Desta maneira, o governo nem sequer via grande inconveniente na existência de um regime de Imprensa livre, desde que reservada às classes ricas" 30 .

Novamente, é importante afirmar que o estabelecimento, por lei, do que eram abusos da liberdade de imprensa não deve ser considerado anti-liberal, pois a regulação do exercício das liberdades sempre foi fundamental para o liberalismo. As determinações financeiras, neste caso, relacionam-se com a sua faceta mais aristocrática, aquela que defendia ser possível medir o valor de um cidadão por suas posses, e materializada em diversos outros pontos da constituição política portuguesa, como o censo eleitoral e divisão entre cidadãos ativos e passivos. Tanto o liberalismo mais radical das Cortes, quanto o bem mais moderado ligado a d. Pedro, estavam genuinamente comprometidos com a liberdade de imprensa, mas os diversos matizes liberais do século XIX não podiam compreender esta liberdade sem algum tipo de controle estatal que impedisse o que consideravam o risco da anarquia e desordem. Em outras palavras, não se trata de qualificar como 'antiliberais' medidas tomadas por governos que, além de se reivindicarem representativos, eram assim reconhecidos, mas sim de incluí-las no rol das atitudes legítimas de um governo liberal na sua concepção oitocentista. O reconhecimento da necessidade de controle conferia poder ao governo para limitar o exercício da liberdade de expressão, o que muitas vezes poderia se tornar

\footnotetext{
${ }^{29}$ Idem, página 162.

${ }^{30}$ Idem, página 164.
} 
em instrumento de exercício de poder. Isso significa dizer que existia uma permanente tensão entre liberdade de imprensa (como valor liberal e também como legislação) e governo liberal, que às vezes sentia-se em condições de permiti-la maior ou menor. Como se verá adiante, e em melhores detalhes, esse é um movimento que também aconteceu no Brasil durante o primeiro reinado e a regência. 


\section{Capítulo 2}

\section{Imprensa e legislação no Brasil: 1820-1824}

Antes da vinda da família real portuguesa para o Brasil, eram proibidas a instalação de tipografias para quaisquer fins e a circulação sem autorização prévia de jornais na colônia. Esse procedimento inscrevia-se numa preocupação mais ampla, de manter o território brasileiro isolado do resto do mundo e totalmente dependente da metrópole. $\mathrm{O}$ aspecto cultural parece ter sido uma preocupação específica do reino, pois aqui, ao contrário das colônias espanholas, também não se criaram universidades ${ }^{1}$, fazendo com que os interessados em adquirir instrução superior viajassem obrigatoriamente à Europa, especialmente à Coimbra, e também se controlou rigidamente o fluxo de importação de livros ${ }^{2}$.

É claro que o contrabando sempre existiu; as bibliotecas dos inconfidentes mineiros de 1789 são o exemplo mais bem acabado da impossibilidade prática de manter a leitura sob vigilância ${ }^{3}$; mas casos pontuais não anulam a regra, ao contrário, reforçam-na: era só ilegalmente que se podia tomar contato, no Brasil, com o que de mais avançado se produzia na Europa ${ }^{4}$.

Com a mudança da corte para o Rio de Janeiro e a elevação do Brasil ao status de reino unido, transformações importantes começam a se operar, na medida em que setores da elite colonial articularam-se à burocracia reinol e que esta passou a ter interesses enraizados na América portuguesa: desde a organização do comércio de abastecimento do Rio de Janeiro, passando pelos investimentos em obras públicas e terras e investimentos em negócios mercantis, cada vez uma parcela considerável dos portugueses que acompanharam a Corte em mudança considerava radicar-se definitivamente na ex-colônia, advogando, se não sua transformação em capital

\footnotetext{
${ }^{1}$ Cf., por exemplo, Sérgio Buarque de Hollanda. Raízes do Brasil. São Paulo: Companhia das Letras, 1995, esp. páginas 119-122; José Murilo de Carvalho. A construção da Ordem. A Elite Política Imperial. Brasília: Ed. Universidade de Brasília, 1980, esp. capítulo 1.

${ }^{2}$ Carlos Toledo Rizzini. O livro, o jornal e a tipografia no Brasil, 1500-1822. São Paulo: Imprensa Oficial do Estado, 1988. Especialmente capítulos V e VI do Livro II.

${ }^{3}$ Segundo Otávio Tarquínio de Sousa, "Não havia rigor policial que evitasse a entrada clandestina de livros e o contágio das idéias que eles propagavam". In Fatos e personagens em torno de um regime. História dos fundadores do Império do Brasil. Belo Horizonte: Itatiaia; São Paulo: Edusp, 1988. Citação à página 25 .

${ }^{4}$ Cabe uma precisão: segundo Villalta, alguns indivíduos conseguiam permissões especiais para ler os livros proibidos - fugindo, assim, da ilegalidade; no entanto, isso que dificultava ainda mais o controle do governo sobre essa circulação, uma vez que abria uma brecha para que também os "desautorizados" adquirissem obras censuradas. Luís Carlos Villalta, Censura literária e circulação de impressos..., op. cit.
} 
definitiva do Império, ao menos uma postergação indefinida da volta do monarca a Portugal ${ }^{5}$.

Como se sabe, a chegada da Corte obrigou uma reformulação dos espaços físicos e políticos da cidade do Rio de Janeiro: construção de imóveis (e atribuição de novos usos aos antigos), estabelecimento de redes de comércio internas, melhoria da infraestrutura urbana. Também era preciso abrigar toda a administração pública, criando novas instituições burocráticas. Especialmente por isso, a inserção do Brasil na dinâmica imperial se alterava profundamente, uma vez que

"as rotas políticas, econômicas e mesmo simbólicas que anteriormente ligavam as partes do Império a Lisboa passaram a convergir para a urbe carioca, onde entrou em funcionamento uma série de órgãos antes inexistentes"6.

O que interessa, aqui, é a portaria baixada por D. João VI em maio de 1808, permitindo a instalação de tipografias (e criando a Tipografia Nacional) e a circulação de jornais, regidas pelas leis portuguesas que determinavam a censura prévia de todos os manuscritos ou impressos que se pretendesse publicar. Por causa disso, somente jornais oficiais ou simpáticos ao governo (os "oficiosos") puderam circular: a Gazeta do Rio de Janeiro, primeiro jornal aqui impresso, divulgava os atos do governo, e a Idade d'Ouro do Brasil, de iniciativa privada, na Bahia, eram representantes dessas orientações ${ }^{7}$.

Com a revolução do Porto, a situação periodística brasileira começa a mudar. Em 26 de fevereiro de 1821- após um levante militar da Divisão Portuguesa, que defendia a imediata adoção da Constituição espanhola, frustrado por intervenção de D. Pedro $^{8}$-, D. João compromete-se a aceitar a Constituição que as Cortes elaboravam. Esse documento copiava a declaração francesa dos direitos do homem no que dizia respeito à liberdade de expressão: "Todo o cidadão pode conseguintemente, sem dependência de censura prévia, manifestar suas opiniões em qualquer matéria (...)" 9 . Para Andréa Slemian,

"No Rio de Janeiro, a adesão aos vintistas em 1821 provocaria, de imediato, a extinção da censura régia sobre os impressos e, portanto, um abrupto

\footnotetext{
5 Maria Odila Leite Silva Dias. A interiorização da metrópole e outros estudos. São Paulo: Alameda, 2005,163 pgs.

${ }^{6}$ Andréa Slemian. Sob o império das leis: Constituição e unidade nacional na formação do Brasil (18201834). Tese de Doutorado, Universidade de São Paulo, 2006. Citação à página 45.

${ }^{7}$ Carlos Toledo Rizzini, op. cit, páginas 332-336.

${ }^{8}$ Maria Beatriz Nizza da Silva. Nova História da Expansão Portuguesa. O Império Luso-Brasileiro, (1750-1822). Direção de Joel Serrão e A. H. de Oliveira Marques. Lisboa: Editorial Estampa, 1986. Esp. páginas 396-412.

9 apud Barbosa Lima Sobrinho. O problema da imprensa. São Paulo: Com Arte, 1988, 173 pgs.
} 
crescimento da produção e circulação de periódicos e panfletos, contribuindo ademais para a liberalização, em nome do direito individual de liberdade de expressão, dos espaços de legalidade política. Com isso, o debate político ganhou publicidade jamais vista e, conseqüentemente, a prática da crítica e discussão uma maior materialidade do ponto de vista de seus suportes"

Sem dúvida, o reconhecimento real da legitimidade da crítica e discussão políticas por meio da imprensa permitiu que o movimento liberal se encorpasse também no Brasil, pois ela passava a ser um poderoso instrumento de disputa entre interesses e projetos de grupos distintos, além de espaço de crítica às autoridades e de mobilização popular; mas não seria ainda o forçado reconhecimento de D. João do poder das Cortes Portuguesas que garantiria imediata liberdade de circulação dos impressos - seriam necessários, para isso, mais alguns meses, a demonstrarem para o monarca e seus ministros a irrefutabilidade da guinada política liberal.

É pelo decreto de 2 de março do mesmo ano que se regula a atividade de imprensa para além dos preceitos gerais da declaração de direitos. Embora se afirmasse, no texto, que a censura prévia dali em diante não mais existiria, ficava disposto que os impressores deveriam enviar duas cópias de todo material que se produzisse em suas oficinas ao Diretor de Estudos, para que ele verificasse a existência de algum atentado contra a segurança ou moral públicas, a religião, o soberano ou a sua Constituição. Após esse exame, daria parecer favorável ou contrário à continuidade da impressão, podendo inclusive sugerir alterações aos trechos que considerasse inadequados. Os livreiros, por sua vez, enviariam ao mesmo Diretor listas com os livros de que dispunham para venda. A não observação destas ordens acarretaria em penas que iam de multas até a detenção, além do confisco dos materiais apreendidos ${ }^{11}$. Dessa forma, o efeito prático desse decreto não era, como ele próprio afirmava, extinguir a censura prévia, mas sim mudar o procedimento pelo qual se encaminhavam os impressos para a Censura, a fim de acelerar o processo $^{12}$. Vê-se que a preocupação apenas torná-la mais rápida a fim de não prejudicar a circulação dos periódicos.

Segundo Marco Morel, é a partir deste momento que se instala a liberdade de imprensa no Brasil. No entanto, sua trajetória não teria um sentido claro, de progresso linear, mas sim seria marcada por constantes avanços e recuos, "em que os dilemas

\footnotetext{
${ }^{10}$ Andréa Slemian. Vida política em tempos de crise: Rio de Janeiro (1808-1824). São Paulo: Aderaldo \& Rothschild Editores, 2006. Citação nas páginas 24-25.

${ }_{11}^{11}$ Coleção das Leis do Império, 2/3/1821.

12 Sem, no entanto, "abrir a porta à libertina dissolução no abuso da imprensa".
} 
vividos pelos redatores de diversas correntes políticas se cruzaria com as preocupações governamentais e com as constantes alterações desta legislação pelos parlamentares" ${ }^{13}$. Esta pesquisa, como se verá, confirma que a liberdade dos jornalistas realmente esteve sujeita a variações que acompanharam o momento político e, principalmente, as intenções do governo imperial. Não se pode afirmar, contudo, que a legislação da imprensa tenha sido constantemente alterada pelo poder legislativo, principalmente porque este sempre se colocou como seu defensor, ainda que advogando controles mais ou menos rígidos.

Em 10 de março de 1821, as Cortes lançam o documento no qual se estabelecem as Bases para a Constituição do Reino Português, que confirmavam sua orientação liberal ao seguir a Carta de Cádiz, então considerada a mais avançada das constituições européias. Os artigos 8, 9 e 10 eram os referentes à liberdade de imprensa - neles, extinguia-se a censura prévia para os jornais políticos, mas mantinha-se a referente aos textos dogmáticos e religiosos, a ser exercida pelos bispos designados pela Igreja para tanto. Dessa forma, revogavam-se as disposições prévias que por ventura instituíssem a censura a periódicos políticos.

A efetiva abolição da censura prévia, no Brasil, acontece em 28 de agosto de 1821, com a decisão do Ministério do Reino que considerava "injusta" sua manutenção após as decisões das Cortes de Lisboa de acabar com a instituição em Portugal ${ }^{14}$. Assim, mandava que não se oferecesse empecilho à publicação de nenhum escrito, obedecendo às regras impostas pelas mesmas Cortes. Estas, como visto na seção anterior, instituíam responsabilidades e penas para autores (ou tradutores) e editores e, na ausência deles, para os impressores, que eram obrigados a inserir na publicação a autoria do trabalho.

A questão do anonimato seria ainda motivo de discussão e reação por parte dos escritores públicos. Em 15 de janeiro de 1822, uma decisão do Ministério do Reino ordenava aos diretores da Tipografia Nacional que não permitissem jamais que se imprimissem textos nos quais o nome do responsável não aparecesse. Quatro dias depois, o ministério recua da decisão, alegando que "espíritos mal intencionados" poderiam interpretar a portaria anterior no sentido de que se estivesse coibindo a liberdade de imprensa, “em sentido inteiramente contrário aos liberalíssimos princípios de S. A. Real e à sua constante adesão ao sistema constitucional", e assim ordenando

\footnotetext{
${ }^{13}$ Marco Morel. As transformações dos espaços públicos. Imprensa, atores políticos e sociabilidades na Cidade Imperial (1820-1840). São Paulo: Hucitec, 2005. Especialmente pp. 200-222; citação à página 205.

${ }^{14}$ Coleção das Leis do Império, 28/8/1821.
} 
que não se colocasse entrave à publicação de quaisquer impressos, e lembrando a hierarquia de responsabilização por eles: autor, editor, impressor ${ }^{15}$.

Cecília Helena Salles Oliveira analisou a função do anonimato nos folhetos políticos das duas primeiras décadas do século XIX em sua dissertação de mestrado. Para a autora, o anonimato era um mecanismo que possibilitava a participação política ativa de pessoas que, por ocuparem determinada posição social ou mesmo algum cargo importante, não desejariam comprometer sua situação criticando a ordem estabelecida. "Assim, o anonimato era um mecanismo através do qual poderia haver participação política sem implicar sanções diretas a quem quisesse expressar seus interesses e pontos de vista"16. Então, mesmo remetendo a uma conjectura - a possibilidade de interpretação errônea de uma ordem-, o texto da portaria parece ser suficiente para causar tensão entre o governo e a elite letrada, que passava cada vez mais a usufruir da liberdade de imprensa e não deixaria passar esse "deslize" de tons absolutistas do imperador.

Em 18 de junho de 1822, um decreto de D. Pedro vinha regulamentar o processo que deveria seguir a justiça nos casos de abuso da liberdade de imprensa. Em seu preâmbulo, elencava as razões que tornavam a medida necessária:

“cumpria-me necessariamente e pela suprema lei da salvação pública evitar que ou pela imprensa, ou verbalmente, ou de qualquer outra maneira propaguem e publiquem os inimigos da ordem e da tranqüilidade da união, doutrinas incendiárias e subversivas, princípios desorganizadores e dissociáveis, que promovendo a anarquia e a licença, ataquem e destruam o sistema, que os povos deste grande e riquíssimo reino por sua própria vontade escolheram, abraçaram e me requereram, a que eu anuí e proclamei, e a cuja defesa e mantença já agora eles e eu estamos indefectivelmente obrigados; e considerando eu quanto peso tenham estas razões e procurando ligar a bondade, a justiça, e a salvação pública, sem ofender a liberdade bem entendida de imprensa, que desejo sustentar e conservar, e que tantos bens tem feito à causa sagrada da liberdade brasílica $(\ldots), 17$.

O trecho expressa a preocupação de controlar a imprensa, porta-voz de projetos de grupos políticos antagônicos, em um momento em que d. Pedro e seus aliados, entre

\footnotetext{
${ }^{15}$ Idem, $15 / 1 / 1822$ e $19 / 1 / 1822$.

${ }^{16}$ Cecília Helena Lorenzini de Salles Oliveira. O disfarce do anonimato. O debate político através dos folhetos (1820-1822). Dissertação de Mestrado, São Paulo, USP, 1979. Citação à p. 25

${ }^{17}$ Coleção das Leis do Império, 18/6/1822.
} 
eles seu ministro do Império, José Bonifácio, já estavam em atrito com as cortes de Lisboa e já vislumbravam a possibilidade de independência. Separar-se de Portugal colocava o desafio de, ao fazê-lo, consolidar no Rio de Janeiro o governo de d. Pedro e do grupo a ele articulado, silenciando eventuais oposicionistas internos. O importante aqui é que o futuro imperador preocupa-se em afirmar o discurso liberal de liberdade de imprensa e o controle dos periódicos é justificado como a limitação de abusos que levariam ao caos e anarquia e portanto contrários ao interesse de um sistema que ele vinculava já a uma liberdade brasílica.

Por outro lado, a liberdade conquistada após a revolução do Porto permitiu que a imprensa tivesse importante papel no processo de independência. Sua importância como veiculadora dos projetos de emancipação do Brasil e peça chave na disseminação e aceitação destas idéias é praticamente inconteste para a historiografia, tanto em produções mais recentes quanto antigas. Para Isabel Lustosa,

"Pode-se dizer que a independência foi sendo conquistada pari passu através das campanhas jornalísticas: primeiro, reagindo aos projetos de recolonização das Cortes de Lisboa; segundo, mediante a intensa campanha de dezembro de 1821, que levou ao Fico no janeiro seguinte; depois, na campanha pela Constituinte brasileira e, em seguida, quase que simultaneamente, na disputa em torno dos limites do poder que haveria de ter o imperador" ${ }^{\prime 18}$.

Nelson Werneck Sodré descreve a progressão dos artigos do Revérbero Constitucional Fluminense, redigido pelos cariocas Joaquim Gonçalves Ledo e Januário da Cunha Barbosa, membros influentes do Grande Oriente Brasiliano, loja maçônica que influiu muito sobre o movimento separatista brasileiro ${ }^{19}$. Os textos do jornal teriam acompanhado de perto o processo da independência: "A linguagem do jornal de Ledo e Januário aumentava em vigor, a cada dia, acompanhando a evolução dos acontecimentos e a crescente exaltação dos brasileiros" ${ }^{20}$, e isso lhes rendeu grande prestígio político. O jornal apoiou o Fico, encabeçou a representação que pedia a convocação do Conselho de Procuradores das Províncias (cargo a que Ledo foi eleito, pelo Rio de Janeiro), passou a defender, em maio de 1822, a separação de Portugal e,

\footnotetext{
18 Insultos impressos: o nascimento da imprensa no Brasil, em A Independência Brasileira: novas dimensões. Jurandir Malerba (org.). Rio de Janeiro: Editora FGV, 2006. p. 241-242.

${ }^{19}$ Seu primeiro grão-mestre foi José Bonifácio, que logo passaria o cargo para D. Pedro; Gonçalves Ledo e Januário Cunha Barbosa sempre foram identificados, junto com José Clemente Pereira, como os líderes dos maçons.

${ }^{20}$ Nelson Werneck Sodré, História da Imprensa no Brasil. Rio de Janeiro: Mauad, 1999. Citação à página 54.
} 
especialmente, advogou a convocação da Assembléia Constituinte. Para o autor, todo o movimento tratou-se de uma manobra, articulada e desenvolvida, para o avanço da independência: comprometeu-se o (então) príncipe Pedro a aceitar o título de defensor perpétuo do Brasil, mas não somente com a cúpula da elite política - foi criada, concomitantemente, uma mobilização que envolvia boletins, cartazes, artigos na imprensa, reuniões privadas e públicas. Era o início de uma politização que ultrapassava os círculos tradicionais da política no Antigo Regime, que abarcava novos segmentos sociais e atingiria seu auge durante o período das regências ${ }^{21}$.

Mas a articulação política não renderia apenas prestígio a Gonçalves Ledo. Suas idéias mais 'radicais' de limitação dos poderes do Imperador e de predominância do parlamento, às quais subjazia a compreensão da soberania como soberania popular, renderam-lhe a perseguição de José Bonifácio, capaz de deportá-lo para a França antes mesmo de estar concluído o processo judicial instaurado após a devassa instalada pelo ministro em novembro de 1822 , no qual foi absolvido ${ }^{22}$.

Como se pode ver, então, é num contexto de preocupação governamental com a capacidade da imprensa de congregar forças em torno de projetos dissonantes que se produz tal decreto; que enfatiza seu potencial destrutivo, já que, deixada sem controles, a imprensa poderia tornar-se um veículo de disseminação das "perigosas doutrinas defensoras da anarquia" e promotoras da desagregação das instituições da nação - ou seja, poderia ser colocada a serviço de grupos políticos que não partilhavam do projeto de país defendido pelo regente e seu governo. Dessa forma, era imprescindível regular o exercício dessa liberdade, como mandavam os preceitos liberais então em voga, a fim de preservar o equilíbrio entre os interesses individuais de expressão de idéias e opiniões e os da nação, de estabilidade pública.

Segundo Barbosa Lima Sobrinho ${ }^{23}$, esse decreto foi mais diretamente provocado pelo jornal de João Soares Lisboa, O Correio do Rio de Janeiro. O autor, infelizmente, não diz do que se tratava o artigo incendiário. Isabel Lustosa afirma que esse foi o jornal que mais diretamente influiu nos acontecimentos de 1822, pois era a mais radical folha em circulação, sendo inclusive a primeira a pedir a instalação de uma Assembléia Constituinte. Soares Lisboa foi também o primeiro redator a ser processado por abuso

\footnotetext{
${ }^{21}$ Marcello Octávio Neri de Campos Basille. O Império em construção: projetos de Brasil e ação política na Corte Regencial. Tese de Doutorado apresentada ao Programa de Pós-Graduação em História Social, Instituto de Filosofia e Ciências Sociais, da Universidade Federal do Rio de Janeiro. Rio de Janeiro, outubro de 2004.

${ }^{22}$ Idem, página 34.

${ }^{23}$ Barbosa Lima Sobrinho, op. cit.
} 
da liberdade de imprensa no Brasil, por conta de artigo no qual chamava D. Pedro de democrata, eufórico que estava com as demonstrações de liberalidade do Imperador. Apesar de ter sido absolvido pelo júri, sofreu grande perseguição do ministério, durante a devassa que ficou conhecida como Bonifácia, tendo de se exilar em Buenos Aires. Ainda assim, ao retornar ao Brasil, no início de 1823, é preso, mas retoma a publicação da cadeia ${ }^{24}$.

Maria Beatriz Nizza da Silva fornece um relato interessante da discussão do Conselho de Procuradores Gerais das Províncias que culminou nesse decreto ${ }^{25}$. Segundo a autora, em 16 de junho o procurador do Rio de Janeiro, José Mariano de Azeredo Coutinho, propôs que fosse entregue ao Corregedor do Crime da Corte e Casa, responsável pelo início dos processos contra os abusos de liberdade de imprensa, o $\mathrm{n}^{\circ}$ 52 do Correio do Rio de Janeiro, "para que fosse punido o seu autor, pelas doutrinas criminosas que continha". A proposta gerou grande polêmica, levantando-se contra ela o outro representante do Rio de Janeiro, Joaquim Gonçalves Ledo, que isentou o periódico de crime e defendeu veementemente a liberdade de imprensa. A solução encontrada pelo grupo, então, foi a regularização das leis em vigor, em forma de decreto a ser redigido por Ledo, depois de acordadas entre o Conselho as suas bases e diretrizes, entre elas a criação de uma Comissão que se encarregasse da fiscalização e do julgamento dos crimes de imprensa.

Na sessão seguinte, em 18 de junho, foi discutido o documento apresentado por Ledo. O estabelecimento das ditas Comissões foi objetado pelo Ministro da Fazenda, Martim Francisco, irmão de José Bonifácio, que argumentou que tais comissões haviam sido extintas pelas Cortes de Lisboa,. e também Ledo protestou contra o uso das antigas leis para o julgamento de tais crimes. Foi o procurador da província Cisplatina, D. José Lucas Obes, quem sugeriu o julgamento por jurados, e a partir daí delineou-se a instituição como constava do decreto.

Segundo Maria Beatriz,

"A questão da liberdade de imprensa, surgida a propósito do Correio do Rio de Janeiro, de João Soares Lisboa, e motivada pela sua defesa da Constituinte e das eleições diretas para seus deputados, mostra bem que o governo do Rio de

\footnotetext{
${ }^{24}$ Isabel Lustosa, op. cit.

${ }^{25}$ Maria Beatriz Nizza da Silva. Movimento constitucional e separatismo no Brasil, 1821-1823. Lisboa: Livros Horizonte, 1988. Exposição às páginas 20 e 21.
} 
Janeiro não estava disposto a permitir vozes dissonantes da política ministerial" 26 .

As perseguições a Soares Lisboa, mesmo depois de sua absolvição, e ao grupo de Gonçalves Ledo ratificariam essa interpretação. No entanto, é patente que as tentativas de calar a oposição, ainda que momentaneamente bem-sucedidas, tornavam-se outra fonte de desgaste e críticas ao governo, que era constantemente obrigado a negociar com facções políticas que se utilizavam da imprensa para publicar seus projetos e angariar suporte político.

O decreto propriamente dito especificava o modo pelo qual se daria o processo nos casos de abuso da liberdade de imprensa: o Corregedor do Crime da Corte e Casa, para a cidade do Rio de Janeiro, ou o Ouvidor do crime (nas províncias que tivessem Relação), ou ainda o Ouvidor da Comarca (para as que não tivessem), seriam os Juízes de Direito dos crimes de imprensa. O Procurador da Coroa e Fazenda, nomeado Promotor Fiscal desses casos, deveria encaminhar a eles pedido de formação de um corpo de jurados, formado por 24 cidadãos "escolhidos de entre os homens bons, honrados, inteligentes e patriotas, os quais serão os Juízes de Fato, para conhecerem da criminalidade dos escritos abusivos". O réu poderia recusar até 16 desses nomes, e lhe era garantida também justa defesa. Havendo culpa, o juiz decidiria a pena cabível, e a sua decisão só cabia apelação à Real clemência.

Esse documento é considerado pelos juristas como o introdutor da instituição do júri no Brasil. De início restrito aos processos dos crimes de liberdade de imprensa, sua instalação ia ao encontro das reformas judiciárias que ocorreram na França após a revolução. Segundo Andre Jardin ${ }^{27}$, a introdução do corpo de jurados, pela assembléia de 1791, consistiu uma inovação essencial, copiada diretamente da Inglaterra e que possibilitava à justiça formal estar mais próxima dos cidadãos, e, mais importante, fazia com que participassem diretamente das instituições. Inclusive, uma conseqüência marcante da prevalência do júri nos julgamentos dos crimes de abuso da liberdade de imprensa na França, como se viu, foi a tendência que apresentou a absolver os escritores acusados, ao contrário dos juízes correcionais.

Godofredo Silva Telles também relaciona a instituição dos jurados com o liberalismo político:

\footnotetext{
${ }^{26}$ Idem, pág. 21.

${ }^{27}$ Andre Jardin. Historia del Liberalismo Politico. Mexico: FCE, 1998. Página 135.
} 
"O Tribunal do Júri tem as aparências de uma instituição liberal. Ele se apresenta como um irmão gêmeo desse parlamento legislativo, dito liberaldemocrático, em que os membros são eleitos por sufrágio universal. Pois ambos parecem nascidos de uma idêntica filosofia. Num e noutro, adivinha-se o predomínio dos mesmos princípios de representação popular e liberdade.”28

José Murilo de Carvalho, de forma semelhante, afirma que a experiência do júri, para os sorteados, significava uma participação muito mais intensa e direta do exercício do poder do que aquela do voto, que se dava de maneira muito rápida e espaçada temporalmente. Na função de jurado, o cidadão aprofundava seu contato com o Estado, entrando em contato com a legislação e os procedimentos judiciários, do que resultava também uma socialização política muito maior do que a proporcionada pela votação. A qualificação exigida para participar do júri era a mesma para ser votante: renda de 200 mil réis nas cidades pequenas, e de 400 mil nas maiores; a diferença era que a alfabetização também era requisito, o que acabava por excluir grande parte da população. Ainda assim, a instituição não perdeu os ares de baluarte da defesa dos direitos políticos e civis ${ }^{29}$.

No entanto, este decreto estabelecia que o corpo de jurados fosse indicado pelo juiz de direito, e não eleito, como era de praxe em legislações estrangeiras. A eleição destes jurados seria colocada em prática com a lei de 22 de novembro de 1823 e definitivamente implementada com a criação dos juízes de paz em 1827. A conseqüência imediata de tal medida é que o júri estaria ligado, dessa forma, a um funcionário direto do governo central, o que certamente influiria nas suas decisões: facilitava que a lei fosse interpretada da forma que mais agradasse ao governo e favorecia a condenação de manifestações da oposição. Mesmo assim, foi um júri indicado que inocentou José Silva Lisboa e os outros pronunciados na Bonifácia.

A eleição dos juízes de fato, por outro lado, repartiria o poder de outra forma, permitindo que os potentados locais interferissem mais decisivamente nas questões judiciárias, por terem condições de eleger aqueles que lhes garantissem proteção. Segundo Thomas Flory, a criação do juizado de paz foi fortemente apoiada por jornalistas, que promoveram uma campanha de suas vantagens até então inédita, por ser

\footnotetext{
${ }^{28}$ Godofredo da Silva Telles Jr. Justiça e júri no Estado Moderno. São Paulo: Empresa Gráfica da 'Revista dos Tribunais', 1938. Tese de concurso para a cátedra de Direito Judiciário Penal da FDUSP. Citação à página 39.

${ }^{29}$ José Murilo de Carvalho. Cidadania: tipos e percursos. In Estudos Históricos, Rio de Janeiro, $\mathrm{n}^{\circ} 18$, 1996.
} 
encarada como uma maneira de contrabalançar o poder imperial e, além disso, fortemente associada à instituição do júri, que em 1827 já havia provado ser um sistema sob o qual se tornara praticamente impossível obter a condenação de um jornalista. Para o autor, então, os editores brasileiros tinham interesses diretos na continuidade do julgamento pelo júri, que fez deles um dos grupos mais favoráveis às reformas judiciárias liberais, por conta da experiência prática de seus benefícios ${ }^{30}$.

A evidência, então, é a de que o processo formal contra os crimes da imprensa tendia a favorecer os acusados de abuso, pois os jurados os absolviam. No entanto, são necessários levantamentos específicos sobre estes processos para confirmar essa tendência, enunciada pela historiografia sem a citação das suas fontes.

Para que os corregedores ou ouvidores estivessem cientes do que se publicava e pudessem dar início aos processos, os impressores estavam obrigados a remeter uma cópia de tudo que se produzisse em suas oficinas. Esse expediente não se confunde com a censura prévia, pois em nenhum momento o texto vincula a circulação do impresso à aprovação das autoridades.

É interessante também a menção do decreto à severidade com que tais crimes eram punidos pelas leis antigas, que não condizia com o "espírito liberal" do novo governo; por conta disso, mandava obedecer ao disposto pelo decreto das Cortes Portuguesas de 4 de junho de $1821^{31}$. Como se viu, este decreto desenvolvia os princípios da liberdade de imprensa, e pode ser considerado a base para todas as leis que seriam desde então elaboradas no Brasil a esse respeito.

Isso porque a tipologia dos abusos que se ali se encontra seria copiada com menores alterações para o caso brasileiro. Dizia-se que eram abusivos da liberdade de imprensa os escritos que atentassem contra a religião católica romana, o Estado e seus agentes, os bons costumes e contra os particulares: as grandes linhas que guiarão tanto o projeto de lei da Assembléia Constituinte como o da Câmara dos Deputados em 1826. As penas que a legislação brasileira implantou em 1823, contudo, eram muito mais severas do que as portuguesas estabelecidas na lei de 1821, mas seriam

\footnotetext{
${ }^{30}$ Thomas Flory, Judge and jury in imperial Brazil, 1808-1871: social control and political stability in the new State. Austin: University of Texas Press, 1981. Esp. página 57 e seguintes.

${ }^{31}$ A data mencionada pelo decreto de D. Pedro não é correta, sendo o decreto das Cortes Portuguesas datado de 12 de julho de 1821; tampouco a utilizada por Tengarrinha, que cita a data de 4 de julho desse ano.
} 
progressivamente abrandadas com a lei de 30 de setembro de 1830 e ainda com o Código Criminal de 1830, especialmente na modalidade de abusos contra o Estado ${ }^{32}$.

No entanto, os pasquins, proclamações incendiárias e outros escritos não impressos continuariam a ser julgados e punidos com o rigor das disposições do livro $5^{\circ}$ das Ordenações Filipinas, certamente por serem de mais difícil controle. Isso fica claro pela última disposição do decreto, que mandava não se imprimirem escritos anônimos, sendo que a responsabilidade criminal cairia sobre o editor ou impressor se isso acontecesse. Vê-se que aqui foi mantida a flexibilização da proibição ao anonimato, aparentemente uma conquista a que os jornalistas não estavam dispostos a ceder, mas não se deixou de lado a garantia de que algum dos envolvidos no processo da publicação haveria de ser por ela responsabilizado.

O desenrolar dos acontecimentos nas Cortes portuguesas, como é sabido, evidenciou a dificuldade de conciliar os interesses de manutenção da autonomia conquistada pelos colonos brasileiros durante o período em que viveram na sede do Reino Unido e o ímpeto 'centralizador' dos portugueses, descontentes com a perda de importância sofrida com a mudança da Corte para o Rio de Janeiro e com a liberalização do comércio brasileiro. A intransigência portuguesa leva ao endurecimento das negociações com os deputados brasileiros às Cortes e, mais importante ainda, à união, no Brasil, dos defensores da separação do Reino em torno deste projeto, ainda que divergissem em pontos fundamentais a respeito da organização política e social da futura nova nação.

Após a proclamação da independência, intensificaram-se os conflitos entre os distintos projetos liberais então colocados para o Brasil pelas elites que se uniram para concretizar a separação do Reino. Nas boas palavras de Nelson Werneck Sodré, “Alcançada a independência, (...) a unidade que se forjara para conseguir a separação cessa. É outro o problema, agora: é o da estruturação do Estado, problema de poder"33.

Seguindo a interpretação de Miriam Dolhnikoff ${ }^{34}$, pode-se afirmar que disputavam o poder dois projetos de organização para o Estado brasileiro. De um lado,

\footnotetext{
${ }^{32}$ A lei das Cortes determinava prisão de cinco anos no caso de excitamento à rebelião; o projeto da Assembléia Constituinte, degredo de 10 anos, e o Código Criminal, prisão de um a quatro anos (art. 90)

${ }^{33}$ Nelson Werneck Sodré, op. cit, p. 46.

${ }^{34}$ Miriam Dolhnikoff. O pacto imperial. Origens do federalismo no Brasil. São Paulo: Globo, 2005. Especialmente cap. 1.
} 
estavam os liberais moderados, entre os quais os paulistas Diogo Antônio Feijó e Nicolau Campos Vergueiro, defensores de estruturas institucionais descentralizadas, capazes de integrar as províncias num único Estado. Para eles, a diversidade econômica e histórica entre as regiões, cujos laços de dependência também não eram fortes, exigia um arranjo institucional capaz de acomodar as elites regionais e lhes garantir espaço de negociação dos recursos e políticas que atendessem seus interesses específicos. Esse era um arranjo que desembocaria numa organização de tipo federativo, garantindo a unidade do Império sob o governo do Rio de Janeiro.

Entre os liberais de todos os matizes, era consenso de que não deveria se tocar nos fundamentos da sociedade escravista brasileira:

"Para esses liberais, a proposta de federação expressava a noção de que modernidade e civilização deveriam concentrar-se no aparelho de Estado. A associação entre modernidade e autoridade em um país escravista de herança colonial assumia, no seu discurso, a feição de uma ação disciplinadora, em lugar de um projeto propriamente civilizatório" ${ }^{35}$.

Tal ação disciplinadora passava pela exclusão, ou inclusão marginalizada, de amplos setores sociais nos espaços políticos e econômicos do Império, assim como por um processo de pedagogia política das elites locais, que deveriam ser instruídas nos trâmites burocráticos do sistema constitucional representativo.

O "projeto civilizatório", por outro lado, era de autoria do grupo que Dolhnikoff chama de "burocratas ilustrados", formados na tradição pombalina e cujo principal representante era José Bonifácio. No entender desse grupo, a construção da identidade nacional e a civilização do país dependiam do fim da escravidão e da integração dos índios, a fim de estender o exercício da cidadania por toda a população e assim construir um verdadeiro Estado moderno, o que só seria realizável mediante reformas radicais operadas por um Estado centralizado e dirigido por homens ilustrados, capaz de impor as reformas necessárias aos poderes locais e regionais. Segundo a autora,

“A concepção de monarquia constitucional atrelada ao projeto civilizador significava um regime centralizado capaz de controlar o processo pelo qual os demais setores seriam incluídos, a fim de garantir que tal inclusão não significasse a perda da direção do Estado pela elite branca"36.

\footnotetext{
${ }^{35}$ Idem, página 46.

${ }^{36}$ Idem, página 54.
} 
Para ambos os grupos, então, prevalecia a concepção liberal-doutrinária de que a nação existia no Estado, manifestando-se por meio de sua organização institucional; o que diferia eram os planos sobre o que seria a cidadania brasileira. A convocação da Constituinte, em junho de 1822, deu forças ao primeiro projeto, ao sinalizar a disposição do Imperador em consentir um arranjo no qual as províncias tivessem voz ativa e um espaço institucional para exprimir seus interesses específicos e negociá-los com o restante da nação. Sua dissolução, em novembro de 1823, significou exatamente o contrário, ou seja, a vitória - mesmo que temporária - do projeto centralizador, embora tenha sido também a derrota dos defensores de reformas estruturais, como Bonifácio. Os conflitos que culminaram com a abdicação de Pedro I em 1831, por sua vez, são relacionados à incapacidade deste último projeto sustentar suas opções institucionais em face às pressões descentralizadoras.

O maior representante do grupo ilustrado, José Bonifácio de Andrada e Silva, ocupou um cargo-chave do Império, o de Ministro dos Negócios do Reino, logo após a proclamação da independência. Sua concepção de centralização certamente não comportava grande tolerância às demonstrações de dissenso em torno de seus projetos, e não tardou a retribuir a oposição que o grupo liberal, entre eles Joaquim Gonçalves Ledo e Januário da Cunha Barbosa, redatores do Revérbero Constitucional Fluminense, lhe fazia. No dia 2 de novembro de 1822, ordenou a instalação de uma rigorosa devassa contra "as penas já acusadas pela opinião pública, e os seus partidistas", a fim de descobrir os "terríveis monstros desorganizadores da boa ordem". Quatro dias depois, nova decisão ordenaria que os designados pela opinião pública como perturbadores fossem colocados fora da cidade do Rio de Janeiro, a fim de se prosseguir a devassa sem os empecilhos que poderiam opor às investigações.

A justificativa para o empreendimento da devassa, como se vê, foi justamente o abuso que se fez, na visão do ministério, do direito de expressão de uma oposição aos rumos que se iam tomando. O governo insinuava um consenso entre os cidadãos de que alguns jornais e seus simpatizantes visavam à desestabilização do sistema e da ordem estabelecidos, ao afirmar que algumas penas eram acusadas pela "opinião pública". Bonifácio chamava os cidadãos "honrados e zelosos" a depor sobre "quaisquer artigos e circunstâncias que ilustrem e provem tão importante objeto, e faça aparecer a verdade em toda a sua luz" ${ }^{37}$. O apelo obteve seus objetivos, pois diversos escritores foram

\footnotetext{
${ }^{37}$ Coleção das Leis do Império, 2/11/1822.
} 
pronunciados - e depois absolvidos, por nada se ter provado contra eles ${ }^{38}$ - e mesmo assim João Soares Lisboa e Gonçalves Ledo foram exilados, cessando assim suas respectivas publicações, que tanto incomodavam o governo. Quando a Constituinte inicia seus trabalhos, as publicações de oposição ainda não tinham voltado à circulação, e o silêncio imposto aos jornalistas só não era total porque os jornais alinhados ao governo continuavam atacando a oposição emudecida ${ }^{39}$.

Segundo Werneck Sodré, é nesse momento em que a liberdade de imprensa, até então concedida pelo poder, é "praticamente anulada" pelos sucessivos atos que restringem seu campo de ação legal, e também por constantes atentados a jornalistas ${ }^{40}$. No que diz respeito à legislação, porém, não se encontram disposições limitando a atividade da imprensa, nem mesmo por meios indiretos, como o aumento de impostos e taxas sobre a postagem ou matérias primas essenciais, como tinta e papel, o que indica que, se houve silenciamento dos escritores oposicionistas, isso aconteceu por meios coercivos extralegais e muito provavelmente de modo a não escancarar a participação do governo.

$\mathrm{O}$ fato de que legalmente os jornalistas tinham seus direitos respeitados, exposto pelas absolvições quase certas, obrigava o governo a tomar medidas de exceção para fazer calar a incômoda oposição (que não era tolerada nem pelo ministro Bonifácio e muito menos pelo Imperador), o que era fonte de desgaste político e dificultava a negociação com setores importantes das elites que reivindicavam compromisso com as garantias liberais para permanecerem partes do Império. A perseguição do governo aos redatores também foi responsável por muitos conflitos entre os poderes executivo e legislativo, então o mais capaz de fazer frente aos ímpetos autoritários de D. Pedro I. Assim, a adoção de um regime liberal, no caso a monarquia constitucional, que implicava necessariamente em uma legislação que garantisse a liberdade de imprensa coibia a ação persecutória do governo. Se não foi suficiente para impedir que silenciasse os periódicos oposicionistas, por outro lado o desautorizou perante o judiciário, criando constrangimentos políticos num momento em que o Legislativo disputava com o Executivo as prerrogativas do poder. O fato de o governo escudar-se no princípio de que punia apenas o abuso de jornalistas que ameaçavam a ordem estabelecida não era suficiente para evitar a tensão política, uma vez que a noção de abuso era altamente

\footnotetext{
${ }^{38}$ Pedro Otávio Carneiro da Cunha. A Fundação de um Império Liberal. História Geral da Civilização Brasileira, tomo 2, volume 1, livro segundo, capítulo V.

${ }^{39}$ Isabel Lustosa, op. cit, página 243.

${ }^{40}$ Nelson Werneck Sodré, op. cit, p. 46.
} 
questionável e a oposição acusava o ministério de perseguir jornalistas por estarem apenas exercendo seu direito inalienável de expressar sua opinião. Um conceito liberal que àquela altura havia se incorporado ao discurso político e se transformara em importante instrumento da disputa entre os distintos grupos.

A convocação e o início dos trabalhos da Assembléia Constituinte trouxe um novo fôlego à política brasileira, pois sinalizou às elites provinciais a disposição do governo do Rio de Janeiro de incluí-las no jogo político para compor o que seria a unidade brasileira ${ }^{41}$, garantindo um espaço institucional para que pudessem expressar suas necessidades e negociar seus interesses. Outro ponto a reforçar sua importância é o de que a feitura de uma constituição, à época, era vista como uma necessidade premente porque, ao estabelecer os termos em que seria organizado o novo ordenamento político, simbolizava a criação do próprio Estado ${ }^{42}$.

O primeiro momento em que a questão da liberdade de imprensa é levantada nos debates foi em 9 de maio, ocasião em que se discutia a anistia aos presos durante a Bonifácia. Antônio Carlos de Andrada Machado, deputado por São Paulo, e irmão do ministro Bonifácio, discursou contra o projeto, por acreditar que a anistia não seria remédio adequado para solucionar o problema da falta de "unidade de opiniões" do império; além disso, afirmou que nenhum juiz seria capaz de prender concidadãos apenas por opiniões professadas, e por isso tal decisão teria alcançado somente aqueles que tivessem traduzido suas opiniões em fatos danosos ao bem social. Nessa fala, já está explícito um consenso que será relembrado quando do início das discussões da lei de abuso da liberdade de imprensa, aquele que distinguia claramente entre opiniões e atos políticos. As primeiras não poderiam ser controladas ou punidas pelo poder público, já que o livre pensar e expressar os pensamentos eram direitos inalienáveis dos cidadãos (e, realmente, nenhum deputado nunca ousou discursar em sentido contrário), enquanto os segundos estariam legitimamente dentro da esfera de preocupações do governo, que deveria garantir a tranqüilidade pública, utilizando inclusive a força caso fosse necessário.

\footnotetext{
${ }^{41}$ Que, de maneira nenhuma, existia previamente à independência, como demonstram Istvan Jancsó e João Paulo G. Pimenta, em Peças de um mosaico (ou apontamentos para o estudo da emergência da identidade nacional brasileira), in Carlos Guilherme Mota (org). Viagem Incompleta: a experiência brasileira (1500-2000). São Paulo: Senac, 2000.

${ }^{42}$ Cf. Andréa Slemian, Um pacto constitucional para um novo Império. Brasil, 1822-1824. Separata de: Visiones y Revisiones de la independência americana - La independência de América: la Constituición de Cádiz y las constituiciones iberoamericanas. Ediciones Universidad de Salamanca, 2007. Para uma discussão do parlamento como espaço de negociação dos interesses das províncias, ver Miriam Dolhnikoff, op. cit.
} 
Em seguida, o próprio José Bonifácio explica os motivos da devassa, repetindo os termos do decreto que a instaurou: era necessário, para a manutenção da ordem pública, identificar e prender alguns indivíduos que a comprometiam.

É o padre José Martiniano de Alencar, deputado pelo Ceará, quem rompe a seqüência dos defensores da devassa, denunciando as medidas arbitrárias tomadas pelo governo na contenção de seus opositores políticos e contestando o ministério:

“Desde 30 de outubro do ano passado a marcha dos negócios políticos do Brasil não é serena e regular. $\mathrm{O}$ governo tem tomado medidas violentas $\mathrm{e}$ anticonstitucionais: tem-se prendido homens sem culpa formada; tem-se deportado outros; abrindo-se uma devassa não só na Corte, mas pelas províncias, que nada menos é que uma inquisição política; a liberdade de imprensa está quase acabada, se não de direito, ao menos de fato. O Rio de Janeiro, donde saíram tantos papéis liberais até aquela data, está hoje reduzido ao Diário das Vendas, ao do Governo, e ao Espelho. Os escritores de maior nomeada estão deportados, ou presos (...),43.

A crítica de Alencar parte do pressuposto da inconstitucionalidade das medidas tomadas pelo governo, apesar de ainda não haver constituição pronta, muito menos estabelecida. Fica evidente que, pelo termo, o deputado tomava a observância de certos preceitos "universais" do liberalismo coevo (observância do devido processo para julgamento, penas proporcionais ao delito, liberdade de opinião e de expressão), com os quais o governo já se teria comprometido. Para Lucia Bastos Neves, a palavra "constituição" representava o remédio para os males políticos do país: defesa do Estado, apoio do trono, nível da perfeita igualdade cívica ${ }^{44}$. Andrea Slemian, por sua vez, afirma que "em princípios dos oitocentos, disseminara-se a crença de que as instituições políticas poderiam forjar a sociedade e seus valores, ou seja, que a lei poderia criar o direito, e não o contrário" 45 . Assim sendo, deve-se considerar que mesmo o significado e a simbologia da 'Constituição' estavam em disputa, como bem lembrara Ledo, no ano anterior, em seu finado Revérbero Constitucional: “Os brasileiros pedem, querem uma

\footnotetext{
${ }^{43}$ ACD, 9/5/1823, p. 47-48.

${ }^{44}$ Lucia Maria Bastos P. Neves. Liberalismo político no Brasil: idéias, representações e práticas (18201823). In Peixoto, Antonio Carlos, Magalhães, Lucia Maria Paschoal e Prado, Maria Emília (orgs.). O Liberalismo no Brasil Imperial: origens, conceitos e prática. Rio de Janeiro: Editora Revan, 2001.

45 Andréa Slemian. Um pacto constitucional para um novo Império: Brasil, 1822-1824. Separata de: Visiones y Revisiones de la independência americana - La independência de América: la Constituición de Cádiz y las constituiciones iberoamericanas. Ediciones Universidad de Salamanca, 2007. Citação à página 194.
} 
constituição liberal, mas antes de se fazer uma Constituição, cumpre determinar o sentido que a esta palavra se deve dar" ${ }^{\prime 4}$.

É então que Diogo Duarte Silva, representante de Santa Catarina, aproveita a deixa para lembrar a assembléia da necessidade de um projeto de lei que regule a liberdade de imprensa:

"Peço a palavra. As vantagens que resultam da liberdade de imprensa são tão conhecidas que eu seria inoportuno tomando o tempo a esta Augusta Assembléia para demonstrá-las. É verdade que ela se acha decretada e provisoriamente regulada pelo Decreto de 18 de junho do ano passado; porém, Sr. Presidente, motivos talvez imperiosos fizeram emudecer a lei; geralmente se crê que tal liberdade não existe de fato. Com a instalação desta Augusta Assembléia devem desaparecer as desconfianças; a liberdade de imprensa deve ressurgir escudada por uma lei protetora; aquela de que falei precisa ser reformada, pois que as circunstâncias em que se achava então a nação brasileira tem mui felizmente mudado. Julgo por isso urgente o que vou propor à Assembléia"47.

No entanto, é interrompido por Antônio Carlos, que o chama à ordem e encerra a primeira lembrança da necessidade de uma lei para a atividade da imprensa na Constituinte $^{48}$.

Ainda no mesmo mês de maio a questão surgiria novamente. No dia 24 , o padre Henriques de Resende faz uma reclamação veemente contra o número 114 do Diário do Governo, do dia anterior. Afirma seu compromisso com a liberdade de imprensa, "mas as idéias expendidas neste Diário do Governo não são as mais conducentes à harmonia e união do grande todo brasiliense". O jornal chamava de desorganizadores os deputados favoráveis à anistia, defendia que D. Pedro I tivesse poderes ditatoriais enquanto não estivesse pronta a Constituição e que esta deveria ser dada ao Brasil da mesma forma que Luís XVIII deu a francesa. O representante de Pernambuco acusa a folha de

“ir temerariamente contra os princípios recebidos, contra a opinião pública, contra as idéias e luzes do século; é querer fazer uma revolução geral em todo o Brasil que não quer receber de ninguém a sua Constituição, pois quer fazê-la, como lhe pertence por um direito que exclusivamente lhe toca. Sr. Presidente,

\footnotetext{
${ }^{46}$ In Maria Beatriz Nizza da Silva, op. cit, pág. 21.

47 ACD, 9/5/1823, página 48.

${ }^{48}$ Segundo José Honório Rodrigues, Antônio Carlos foi a figura de maior destaque nos trabalhos da Constituinte, exercendo grande liderança especialmente por dominar os trâmites a serem seguidos durante as sessões, sendo assim capaz de pautar as discussões e conduzir os debates. José Honório Rodrigues. A Assembléia Constituinte de 1823. Petrópolis: Vozes, 1974.
} 
trabalha-se continuadamente na sapa para dar com este edifício em terra; procura-se abalar as idéias, e a opinião pública, minar pelos alicerces a Constituição, e deitá-la abaixo. Isto é subversivo, é contrário à harmonia e união do Brasil, e só próprio a produzir uma completa revolução" 49 .

Com essa intervenção, o deputado aproxima-se daqueles que, opondo-se ao predomínio do imperador, defendiam o parlamento como representante do país e, como tal, o único autorizado a elaborar sua lei fundamental. Discussão essa que reflete a polarização maior, que dominou os trabalhos tão logo se iniciaram, entre aqueles que defendiam a predominância política do poder legislativo e os favoráveis a maiores prerrogativas para o Imperador.

Duarte e Silva, então, aproveita para novamente falar da necessidade de uma lei de imprensa, e outra vez é Andrada Machado quem se opõe à indicação, agora por lembrar que o país já contava com uma lei sobre o assunto, que não estava revogada e, portanto, não seria necessário a edição de uma nova. Duarte e Silva replica, rebaixando a lei que vigorava a um simples

“decreto de Sua Majestade Imperial que manda provisoriamente, que em certos casos que aponta, sejam tais delitos julgados por jurados, executando-se naquela parte somente a Lei de Liberdade de Imprensa promulgada pelas Cortes de Lisboa" e, dessa forma, a lei era somente "uma parte de uma Lei estrangeira, aprovada unicamente para casos específicos"

Lembrança oportuna, que descreve com exatidão a situação legal do tema.

João Antônio Rodrigues de Carvalho, representante do Ceará, defende o estatuto da lei, lembrando que a validação das leis existentes já havia sido acordada pela Assembléia; se o caso fosse de inadequação, caberiam reformas que lhe aprimorassem o cumprimento, mas nunca se poderia dizer que não havia lei, "porque assim damos idéia de que temos abraçado o sistema Constitucional, mas sistema vazio, e sem alma, qual é a liberdade de imprensa". Novamente se vê a íntima relação percebida, pelos deputados, entre sistema constitucional e liberdade de imprensa, compreendida como direito e, assim, regulada.

A continuação do discurso de Rodrigues de Carvalho é especialmente interessante por introduzir termos que pautariam o restante do debate:

\footnotetext{
${ }^{49}$ ACD, 24/5/1823, pp. 112-113.

${ }^{50}$ Idem, p. 113.
} 
"Pode não haver liberdade de imprensa de fato, mas que tem isso com a liberdade de direito? Uma nova lei guiará a opinião pública? Não certamente, não é por temor de violar uma lei que estará sujeita a liberdade, podem muitas coisas influir, e essas causas nem provêm elas da lei, nem ela pode removê-las. Portanto não se diga que é necessário para a liberdade de escrever uma lei, porque não a temos; diga-se que precisa reformar-se a lei, se a Assembléia julgar que tal reforma é urgente, por defeito da lei existente" ${ }^{, 51}$.

O deputado revela sua inclinação para o grupo de José Bonifácio ao contrapor a liberdade de fato à de direito: se a lei está em vigor e orienta a ação dos escritores, a falta de manifestações impressas da oposição não tem relação com o diploma legal, mas sim com motivos outros, que estão fora da alçada da lei e, por extensão, dos constituintes. Carvalho também antecipa uma vertente forte das manifestações de Bonifácio, a proclamação do caráter privado das considerações que faz um indivíduo ao cogitar abrir um jornal.

O próximo orador, representante da Paraíba, foi Augusto Xavier de Carvalho, que começou afirmando que lamentava

"com muita amargura que entre nós esteja de fato quase suprimida a faculdade de falar, escrever e imprimir (...). Em verdade, Sr. Presidente, houveram nesta Corte ótimos escritos liberais, escritos que, como pela mão, levavam o povo à grande causa que enfim abraçou, que adotamos, e que gloriosamente juramos defender; mas, ó mágoa!, desapareceram, calaram-se, já não existem; e a liberdade nascente vacila, balbucia entre as mãos venais desses poucos escritores que ficaram, miseráveis, desprezíveis e até condenáveis" ${ }^{\text {"52. }}$.

A lacrimosidade do deputado, apesar de aparentemente situá-lo no campo daqueles que censuram o ministério pelas medidas que tomou no sentido de limitar a liberdade dos jornalistas e pedem que uma nova lei seja publicada, na verdade legitima a apresentação de um proto-projeto que apenas declarava em pleno vigor a lei que já regulava a atividade de imprensa, indo ao encontro do grupo que negava a existência de restrições legais aos escritores, defendia o pleno vigor dos decretos existentes e, dessa forma, rechaçava a feitura de nova lei. Provavelmente, o mais importante para os defensores de uma nova lei era a discussão que ela ensejaria, tanto sobre os princípios que deveriam norteá-la quanto sobre as atitudes 'despóticas' do governo, abrindo assim

\footnotetext{
51 Idem.

${ }^{52}$ Idem.
} 
mais uma brecha para que a oposição a D. Pedro e seu ministério se pudesse exercitar. Segundo Thomas Flory, a posição claudicante do imperador em relação à liberdade de imprensa era tida como demonstração de seus princípios pouco liberais; deveria ser claro para seus correligionários que esse assunto não favorecia o governo, e daí a insistência em evitá-lo. Uma fala de Custódio Dias, nessa mesma discussão, confirma essa análise:

"Sua Majestade, quando ainda Príncipe Regente, desaprovando o escrito intitulado Compilador disse ao seu autor em minha presença que escrevesse contudo o que quisesse, mas que se lhe dessem pancadas não lhas tiraria do corpo; e eu sobre isto the manifestei que a liberalidade e não o terror the conciliaria o crédito que havia perdido na Província de Minas por se haver abandonado ao partido da Tropa Européia, sendo certo que a liberdade de imprensa por ele concedida lhe havia granjeado o público louvor" ${ }^{25}$.

O padre mineiro informa que o estabelecimento da liberdade de imprensa havia sinalizado um compromisso do Imperador com o liberalismo, e era capaz de contrabalançar o descontentamento que se seguia à permanência de portugueses suspeitos de não apoiarem a causa nacional na tropa e no governo.

Voltando ao debate, era a vez, então, de o ministro José Bonifácio tomar a palavra para defender as ações do governo, retomando os termos utilizados por Rodrigues de Carvalho:

“diz ele [Xavier de Carvalho] que está suprimida a liberdade de imprensa, mas quando assim se queixa, porque não mostra a lei que a suprimiu, ou não aponta a menor insinuação para não se escrever? (...) Se alguns escritores publicaram folhas que depois não continuaram, foi porque uns perderam na sua publicação, outros até ficaram endividados com a imprensa; e alguns destes que não continuaram em jornais imprimiram folhetos, como eu sei, porque recebo todos os papéis, tanto da Imprensa Nacional como das outras. Por conseqüência, cada um escreve o que bem lhe parece, e os que não escrevem é porque não querem, ou porque não esperam interesses; enfim, isto é objeto de especulação, é negócio de particulares, com que o governo se não embaraça. Portanto diz uma falsidade quem assevera que não há liberdade de imprensa: a lei está em vigor, e o

\footnotetext{
${ }^{53}$ Idem, página 114.
} 
governo nunca pretendeu destruí-la; o contrário disto é uma calúnia, que os fatos desmentem",54, 55 .

A ausência de medidas legais que atravancassem direta ou indiretamente a impressão de periódicos ${ }^{56}$ é alardeada como prova de que o governo não se empenhava em restringir a liberdade de imprensa. Essa afirmação corrobora a hipótese de que houve preocupação, por parte do ministério, em não oficializar a perseguição aos opositores, mas sim de trabalhar nos bastidores para neutralizá-los. O motivo de tal zelo sem dúvida está relacionado com o tipo de consenso que se construiu em torno da necessidade da existência de uma imprensa livre para o sucesso das instituições constitucionais-representativas que se construíam - está claro desde já que era impossível que qualquer político minimamente comprometido com a nova ordem, ou com a construção de sua carreira, falasse ou agisse abertamente contra a liberdade de imprensa.

Para Bonifácio, a ausência de jornais opositores ao governo era uma questão privada, relativa ao cálculo particular de lucros e dividendos que cada redator faria para julgar vantajoso ou não iniciar uma publicação. Assim fazendo, exime o governo de qualquer ingerência na esfera pública brasileira. Se esta fosse uma posição coerente e sólida do ministério, ele provavelmente proporia o fim de qualquer regulação da imprensa, deixando que o "mercado" das opiniões se encarregasse de selecionar as melhores publicações, que mais satisfizessem o público leitor, premiando-as com a sua audiência e a longevidade que dela viria. Mas, ao contrário, essa argumentação economicista apenas procurava esconder os cálculos políticos a respeito do assunto, referentes ao poder dos jornalistas de angariar apoio (popular e das elites) para seus projetos dissonantes dos do governo, ao desgaste que repetidas críticas impunham à imagem do imperador e ao perigo que representavam para a manutenção da ordem que se pretendia estabelecer. A perseguição à imprensa de oposição era evidentemente operada pelo ministério, muitas vezes com suspeitas de mando do próprio imperador. $\mathrm{O}$ caso emblemático é o de Luis Augusto May, jornalista e deputado da Constituinte.

Sua publicação, A Malagueta, teve grande impacto na Corte quando das movimentações para a proclamação da independência, provocando inclusive o

\footnotetext{
${ }^{54}$ Idem, página 114.

${ }^{55}$ Como se vê, mesmo propondo uma revalidação da lei, Xavier de Carvalho foi combatido por Bonifácio (e, em seguida, também pelo irmão Antônio Carlos) por afirmar que, informalmente, existiam empecilhos para que os jornalistas publicassem.

${ }^{56}$ Confirmada por meio do levantamento das portarias, leis, decisões e decretos constantes da Coleção das Leis do Império.
} 
surgimento de outras para contradizê-la. Em sua edição inaugural, declarou-se independente de partidos, o que significava não estar alinhada nem ao grupo de Ledo e Januário nem ao de Bonifácio. Apareceu no mesmo momento em que chegou ao Brasil a decisão das Cortes portuguesas de mandar D. Pedro retornar à Europa, ao que se opôs fortemente e, com isso, angariou simpatia e audiência do público do Rio de Janeiro favorável à permanência do príncipe, e foi o único jornal a noticiar o Fico no dia seguinte ao acontecimento ${ }^{57}$. Após a independência, contudo, passou a fazer ferrenha oposição ao governo. O fazia em nome dos princípios liberais que julgava terem sido abandonados pelo imperador e seus ministros. Mas há versões de que a verdadeira razão foi o fato de ter sido preterido para um cargo de representante internacional e, assim, de bajulador do trono passou a atacar o absolutismo do governo em sua folha ${ }^{58}$, já em 1823. A atitude lhe rendeu uma réplica do Espelho ${ }^{59}$, cuja autoria é creditada a D. Pedro, que enxovalhava May nos termos mais chulos. No dia seguinte, sai a Malagueta Extraordinária que instava o Imperador a desmentir o boato sobre a autoria. Tal 'atrevimento' não passou impune, e o jornalista foi atacado em sua casa por alguns homens armados de espadas e paus ${ }^{60}$. Bonifácio foi acusado pela oposição de ser o mandante do ataque. Nunca se soube ao certo quem estava por trás da agressão ao jornalista, mas o fato é que nestes primeiros anos a disputa gerada pelos periódicos não ficava apenas no campo institucional. O processo de regramento do exercício da liberdade de imprensa e sua institucionalização plena acompanharão o processo de construção do Estado nacional.

Voltando ao debate, a tentativa de Bonifácio de apelar para motivações econômicas também não encontra eco na produção historiográfica, que sempre reforça o caráter militante dos impressos em oposição a essa suposta orientação mercantil que o ministro faz parecer prevalecer ${ }^{61}$. Segundo Nelson Werneck Sodré, a imprensa da época, que ele classifica como romântica e artesanal, "não tinha sentido comercial; sua

\footnotetext{
${ }^{57}$ Nelson Werneck Sodré, op. cit., página 62.

${ }^{58}$ Isabel Lustosa, op. cit.

${ }^{59}$ Redigido por Manuel Ferreira de Araújo Guimarães, antigo redator da Gazeta do Rio de Janeiro. Era um jornal baseado quase que exclusivamente em artigos insultosos à oposição ao governo, especialmente o grupo de Ledo e Januário e, mais tarde, a May. Isabel Lustosa, op. cit.

${ }^{60}$ Marcelo Basille afirma que o artigo era realmente obra de D. Pedro; Nelson Werneck Sodré diz que não se pode ter certeza, mas que tal suspeita é verossímil: "se o estilo é o homem, a verrina retratava nitidamente o desatinado Bragança" (Sodré, op. cit, página 62). Quanto à autoria do atentado, ambos reforçam a idéia de que teria sido ele o mandante, apesar de na época suspeitar-se de que teria, inclusive, participado do espancamento.

${ }^{61}$ Pode-se dizer que tal orientação até se revelava em algumas poucas folhas, como o Jornal do Commercio carioca, que, ainda assim, nunca deixou de evidenciar suas orientações e preferências políticas.
} 
venda não se destinava ao sustento do redator. Não era fim - era apenas meio de ação, e dos mais terríveis" $"$.

Considerando, então, que um discurso sobre a imprensa abertamente repressivo não seria politicamente tolerado, e que, aparentemente, o cumprimento da lei que regulava as atividades da imprensa se dava no sentido da absolvição dos acusados pelo júri popular, pode-se vislumbrar um limite do sistema constitucional representativo brasileiro à época do I Reinado, já que se trata de uma situação em que o governo recorreu com considerável freqüência a medidas extraordinárias para conter movimentos legítimos de oposição. Um caso patente de convivência entre uma nova sociabilidade política, que negociava legalmente as possibilidades de expressão pública das idéias e impunha limites ao imperador, e uma antiga política estatal de repressão àquilo que contestasse o poder real, descrita por muitos historiadores como uma "cisão espiritual" de D. Pedro entre o liberalismo e o absolutismo ${ }^{63}$.

Neste sentido, a oposição ao seu poderoso ministro na Constituinte, justamente na questão da liberdade de imprensa, foi um exemplo da articulação oposicionista. Joaquim Manuel Carneiro da Cunha, deputado pela Paraíba, apontava como essencial ao sistema e ao país o exercício da livre expressão através da imprensa e denunciava o governo que a sufocava:

"Não existe liberdade de fato, embora exista de direito; porque os escritores liberais, que escreviam no Rio de Janeiro, calaram-se, desapareceram, e todos sabem que uns foram deportados, outros presos, e que denúncias, devassas inquisitórias, perseguições e terrores agrilhoam o pensamento de quem intenta escrever livremente; apenas aparecem em campo dois que escrevem em direção oposta à opinião geral. (...) Se há liberdade, é só para se atacar o Congresso e a todos aqueles deputados que votam contra as opiniões de alguns, que inserem cartas nas folhas dos atuais redatores, onde são por esses descamisados taxados de anárquicos. Se de direito, Sr. Presidente, existe a lei, torno a repeti-lo, não existe de fato; e por isso é de absoluta necessidade que seja protegida, porque ela é para um Estado que se quer constituir livre como para nós o ar que respiramos:

\footnotetext{
${ }^{62}$ Nelson Werneck Sodré, op. cit., página 165.

63 Para exemplos dessa interpretação, cf especialmente Otávio Tarquínio de Souza. História dos fundadores do Império do Brasil - A vida de D. Pedro I (v. 3). Rio de Janeiro: Livraria J. Olympio, 195758; Tobias Monteiro. História do império: o primeiro reinado. Belo Horizonte: Itatiaia, São Paulo: EDUSP, 1982; Pedro Otávio Carneiro da Cunha, op. cit.
} 
se nos falta, morremos; e eu altamente declaro que não quero habitar o desgraçado país onde não haja perfeita liberdade"64.

Para Cunha, não era legítimo que o governo apadrinhasse determinadas expressões políticas e perseguisse outras; além disso, traz à tona um aspecto totalmente ignorado nas discussões posteriores a respeito das leis de imprensa: a necessidade de protegê-la, garantir a livre expressão, e não regular as possibilidades de mau uso.

O deputado ainda conta o caso da folha chamada $O$ Regulador, que, mesmo proferindo as mais "descabidas" doutrinas contra o sistema constitucional, havia recebido o favorecimento do governo, que mandara às províncias ordens de adquirir assinaturas da folha, e afirma que o fato prova a inexistência da liberdade de imprensa no país. Esse tipo de queixa dos parlamentares foi repetido algumas vezes, e, curiosamente, nunca obtiveram do governo uma resposta que negasse a proteção acusada, mas sim uma série de argumentos que, esperava-se, justificavam o apadrinhamento, pelo executivo, de determinada folha.

Foi justamente o que aconteceu neste caso. Bonifácio levanta-se para "mostrar que o discurso do nobre propinante é um tecido de falsidades, uma miséria". Esclarece que, de fato, o redator d' $O$ Regulador havia procurado o Imperador a fim de obter algum privilégio para sua publicação, e que o monarca consentiu em escrever para as províncias recomendando a assinatura, caso o jornal fosse digno dela ${ }^{65}$. E ainda encontra espaço para inverter a acusação que era dirigida ao governo:

"Por ventura compete-lhe [ao governo] notar, e dizer ao redator que não escreva estas ou aquelas doutrinas? O nobre propinante que tanto quer advogar a causa da liberdade, não vê que isto seria atacar o direito que tem o cidadão de escrever o que muito bem lhe parece? Se o que escreve publica doutrinas nocivas, é mau cidadão, e a lei o punirá; se as escreve proveitosas, será reputado bom cidadão. Demais, se o papel é bom todos o compram, e se é mau não se vende, e perde-se a especulação. Enfim, Sr. Presidente, deixemos as máscaras e falemos claro: o que se queria era que o governo favorecesse os escritos desorganizadores,

\footnotetext{
${ }^{64}$ ACD, 24/5/1823, p. 114.

${ }^{65}$ Como bem nota Andréa Slemian, ainda eram comuns que o imperador concedesse favores e privilégios a particulares, prática secular em Portugal, que pavimentava relações políticas e mesmo pessoais. Contudo, ainda que muito presente em níveis imediatos e cotidianos, "os novos tempos" liberais permitiam que fosse duramente criticada. Andréa Slemian. Vida política em tempos de crise, op. cit, especialmente páginas 40-42.
} 
subversivos da ordem estabelecida, contrários à grande causa que abraçamos e juramos; mas José Bonifácio nunca o consentirá"66.

A fala do ministro deixa clara a dificuldade reinante em definir padrões aceitáveis para a moralidade da atividade da imprensa. Deve-se ter em mente que os limites da expressão pública das opiniões ainda estava sob intensa disputa, na qual se atribuíam diferentes significados aos possíveis abusos, para compreender a afirmação de que não cabia ao governo controlar o que o cidadão escrevia - justamente o que colocara em prática poucos meses antes. Para Bonifácio, o ataque ao governo era sinônimo de ataque ao sistema adotado, e não podia ser tolerado.

A insistência na visão empresarial do jornal, que, segundo ele, manter-se-ia financeiramente de acordo com a popularidade das idéias que defendesse, não era compartilhada por nenhum de seus colegas deputados - e nem pelas atitudes do próprio governo, que tratava de beneficiar (ainda que indiretamente, como o caso d' $O$ Regulador comprova) as folhas que professavam as opiniões de seu gosto e interesse. Esta é uma marca da "novidade" moderna, que admite a necessidade da existência de veículos de comunicação capazes de espalhar idéias e opiniões que sustentem publicamente as ações de um governo que, agora, representa a nação, e não mais uma dinastia, e por isso precisa contar com o seu apoio, materializado na chamada "opinião pública" (aquela devidamente selecionada e depurada, obviamente).

A discussão termina com a decisão de que se enviasse ofício ao governo solicitando que se ordenasse ao Procurador da Coroa e Soberania Nacional a acusação, no Juízo dos Jurados, do nº 107 do Diário do Governo,

"por induzir suspeitas contra a boa fé e a adesão da Assembléia à forma de Governo Constitucional, recomendando ao mesmo procurador que, como ex officio lhe incumbia, fizesse estas acusações em casos semelhantes".

Os termos da solicitação evidenciam novamente a dificuldade de estabelecer critérios claros e objetivos para a definição dos 'abusos', recorrendo ao termo genérico “adesão à forma de Governo Constitucional", que já era mobilizada pelo grupo próximo ao Imperador para justificar as perseguições que empreendia contra seus inimigos políticos. A diferença, neste caso, é que a medida visava preservar o poder legislativo dos ataques da imprensa.

\footnotetext{
${ }^{66} \mathrm{ACD}, 24 / 5 / 1823$, p. 114.
} 
Seria só no início do mês de outubro que a Comissão de Legislação ${ }^{67}$ apresentaria à Assembléia o projeto de lei contra os abusos da liberdade de imprensa, indicando vitória da oposição, que reivindicava a elaboração de nova legislação sobre o assunto. Para a primeira discussão, no dia 23, não se apresentam oradores. No dia 8 de novembro, inicia-se a segunda discussão. $\mathrm{O}$ debate mais significativo gira em torno do disposto no artigo $3^{\circ}$, que determinava a extensão da pena de perda de exemplares (mais o dobro de seu valor) àqueles que comprassem impressos que não trouxessem estampado na capa o nome do seu responsável, para além, é claro, dos próprios impressores. Vergueiro sugere emenda que suprimisse essa disposição, e os discursos colhidos pelos taquígrafos são somente de deputados que se opuseram à sugestão: Francisco Gê Acaiaba de Montezuma, deputado de sua província natal, a Bahia, seu conterrâneo, Luís José de Carvalho e Melo, futuro Visconde da Cachoeira, e França ${ }^{68}$, cujas palavras são aqui reproduzidas:

"Eu acredito que a pena imposta no Artigo contra o comprador é mui política, porque tende a constituir um fiscal do abuso da liberdade de imprensa em cada Cidadão; o qual, se obra de boa fé, examina imediatamente, e antes de comprar a obra, se ela tem estampado o nome do impressor, o lugar e ano da impressão; e deixando de comprá-la por falta destes requisitos, diminui-lhe a extração, e torna gravosa ao Autor, ou ao impressor, a publicação; e se procede de má-fé, lá tem essa pena que lhe impõe o Artigo, que é mui proporcional e razoável para a curiosidade purgar o seu delito." ${ }^{.69}$.

Para estes deputados, o comprador de impressos que não seguissem as exigências legais também deveria ser penalizado. Além da presunção de que todo cidadão deveria conhecer os pormenores da legislação, os deputados tentavam instituir uma espécie de vigilância social sobre a imprensa, estimulando (ainda que negativamente) os leitores a apenas incentivarem publicações identificadas, dificultando, assim, a saída de obras anônimas, notadamente as mais violentas e enfáticas em suas exposições. Mais uma vez, o anonimato é perseguido e ameaçado; ainda assim, e apesar da oposição, a emenda de Vergueiro é aprovada pelo plenário ${ }^{70}$.

\footnotetext{
${ }^{67}$ Formada por João Antônio Rodrigues de Carvalho, deputado do Ceará, Bernardo José da Gama desembargador eleito em Pernambuco, Estevão Ribeiro de Rezende, constituinte de Minas Gerais, assim como José Teixeira da Fonseca Vasconcelos e José Antônio da Silva Maia.

${ }^{68}$ Não pude precisar se era Manuel José de Sousa França, advogado, representante do Rio de Janeiro, ou Antônio Ferreira França, médico, deputado pela Bahia.

${ }^{69}$ ACD, 8/11/1823, p. 384.

${ }^{70}$ Não é possível saber, infelizmente, se houve discursos defendendo a publicação anônima.
} 
Dois dias depois, retoma-se a discussão, desta vez do artigo $6^{\circ}$, referente ao abuso de incitar rebeliões pela imprensa. A pena prevista era de dez anos de degredo e multa de oitocentos mil réis. É nesse momento que surgem tentativas de tornar as penas ainda mais duras: Pedro José da Costa Barros, deputado cearense, sugere que o degredo seja perpétuo, e Carvalho e Melo vai além, defendendo que, para manter a proporcionalidade entre delito e pena, esta deveria ser a condenação à morte. Segundo o deputado da Bahia, era "este o pensar dos mais célebres Filósofos Criminalistas; é a regra dos Códigos mais modernos das Nações civilizadas, e é preceito da Legislação que está em uso entre nós"71. Não é possível precisar a que nação específica Mello se refere, pois nem em Portugal nem na França a pena de morte era mobilizada para este tipo de crime. De qualquer forma, não há de se duvidar de que a pena capital para os abusos de liberdade de imprensa fosse defendida por alguns juristas ao redor do mundo.

Em resposta, Antônio Carlos (agora na oposição ao Imperador, uma vez que seus irmãos, Bonifácio e Martim Francisco, haviam se demitido do ministério por desavenças com ele) defende que a pena seja mais branda do que os 10 anos de degredo e recusa a tese da proporcionalidade desenvolvida pelo deputado baiano: "Tais crimes são crimes dos tempos, filhos do fogo das nossas idéias e das nossas paixões; e a pena é portanto desproporcionada ao crime principalmente em um Governo Constitucional"72. O Andrada expõe então idéia curiosa - fazer da pena de degredo um instrumento para povoar áreas mais desabitadas do país. Afirma ainda que não se podia fazer leis tão duras que impedissem a própria publicação. No fim de sua fala, manda emendas ao artigo, mas a discussão é interrompida em seguida para a leitura de um ofício do ministro da Marinha, notificando a demissão de alguns membros do ministério e a nomeação substitutiva. No dia seguinte, 11 de novembro, precipita-se a crise que seria a responsável pela dissolução da Assembléia, deixando assim apenas os primeiros artigos do projeto discutidos.

É no intervalo entre as duas discussões do projeto que David Pamplona apresenta um requerimento à Assembléia, no qual exige providências a respeito da violência que havia sofrido de dois oficiais portugueses, que lhe creditaram erroneamente uma ofensa feita à tropa por uma correspondência inserta no jornal $A$ Sentinela da Liberdade na Guarita da Praia Grande, sob o pseudônimo de 'Brasileiro Resoluto'.

\footnotetext{
${ }^{71}$ Idem, página 392.

${ }^{72}$ Idem.
} 
Este caso, como se sabe, seria o estopim da crise utilizada pelo governo como justificativa para a dissolução da Assembléia $^{73}$. No dia 6 de novembro, data da apresentação do requerimento, a reação dos deputados foi de estranhamento e indignação. José Joaquim Carneiro de Campos, constituinte eleito pelo Rio de Janeiro, julgou ser o caso um exemplo da perniciosidade dos abusos da liberdade de imprensa, e assim sendo, era necessário correr com a aprovação do projeto, pois se tratava de uma das matérias mais urgentes: "Tratemos portanto desse Projeto de Lei, pois nada me parece mais necessário do que coibir tão desenfreada liberdade",74.

No dia 8, entra em discussão o parecer da Comissão de Justiça sobre o requerimento de Pamplona, que recomendava que o caso fosse remetido ao poder judiciário, não sendo da alçada da Assembléia. Antônio Carlos faz um discurso inflamado contra a posição da Comissão, explorando a sanha nacionalista que se ia acendendo cada vez mais contra a importância de portugueses na política e economia brasileiras. No final, ainda afirma que não se tratava de abuso de liberdade de imprensa, mas sim de conflito aberto entre brasileiros e portugueses.

Sua fala anima deputados e a platéia, que aplaudiu e gritou seu apoio. O sussurro continuou mesmo depois do pedido de silêncio do presidente da Câmara, que desiste de continuar com a sessão e a dá por encerrada. A sessão seguinte, em 11 de novembro, é iniciada pelo pedido de Antonio Carlos de que fosse permitido ao povo que não conseguira se instalar nas galerias assistir ao plenário junto dos deputados, mantendo o silêncio e bom comportamento. Além disso, levando em consideração a presença de tropas pelas ruas da Corte no dia anterior, sugere que se declare a Assembléia em sessão permanente, até que se discutisse com o Imperador os motivos de tal providência. Ambos os pedidos são aprovados, e além disso a Comissão especial, criada para lidar com a situação ${ }^{75}$, oficia ao Imperador um pedido de explicações a respeito do motivo do movimento das tropas pela cidade, começado na noite anterior.

A resposta de D. Pedro chega à uma da manhã. Nela, diz-se surpreso pelo desconhecimento da Assembléia do estado de agitação no qual se encontrava a capital, causado por impressos incendiários e manifestado inclusive na sessão anterior, obrigada

\footnotetext{
${ }^{73}$ Cf. José Honório Rodrigues, op. cit.

${ }^{74}$ ACD, 6/11/1823, p. 369.

75 Formada por Nicolau Pereira de Campos Vergueiro, deputado paulista, Pedro de Araújo Lima, pernambucano, Felisberto Caldeira Brant, baiano, Antônio Carlos de Andrada Machado e pelo Barão de Santo Amaro, José Egídio Álvares de Almeida, baiano eleito pelo Rio de Janeiro.
} 
a terminar mais cedo por conta das intervenções dos espectadores. Em resposta ao questionamento sobre quais seriam os periódicos abusivos, é taxativo:

"são os denominados Sentinela da Praia Grande e o Tamoio, atribuindo-se a redação aos Ex. Deputados Andrada Machado, Ribeiro d'Andrada e Andrada e Silva a influência naquele e a redação neste, o que muito custa a crer Sua Majestade Imperial; sendo a conseqüência de suas doutrinas produzir partidos incendiários, de que o Governo não pode calcular a força que tem e poderão adquirir" ${ }^{\text {, } 76}$.

D. Pedro utilizava, nesse momento, a oposição aberta de algumas publicações como justificativa para mobilizar suas tropas e, assim, demonstrar sua força contra a oposição. Esse movimento não passa despercebido por deputados como Carneiro da Cunha e Bonifácio; nas palavras do primeiro,

“como é possível que esta seja a causa de se achar acampada a tropa? Por ventura não tem havido em todos os tempos periódicos incendiários? Não se tem lido no Diário do Governo tantas doutrinas perturbadoras? (...) As doutrinas são incendiárias, menoscabavam o corpo legislativo e a dignidade desta Assembléia, mas o governo não se embaraçou com isso, e falando-se aqui de tão indignos escritos, respondeu-se que como havia liberdade de imprensa era livre a cada um expor a sua opinião, e esta ser contrariada pelos que a não seguissem. Sr. Presidente, falemos por uma vez claro: este não é o motivo dos acontecimentos de que somos testemunhas"77.

Invocando as palavras de Bonifácio quando ainda ministro, Cunha expõe o tratamento ambíguo dispensado a escritores de diferentes correntes políticas: aos apoiadores do governo, tolerância e liberdade de expressão, e para os opositores repressão armada. Verifica-se, então, como a legítima prerrogativa de limitar o exercício dos direitos individuais podia ser manipulada de acordo com os interesses do governo; por outro lado, também fica claro que essa não era uma operação fácil - havia levantes, especialmente por parte dos parlamentares, mas também dos periódicos e de setores da sociedade civil, contra tais tentativas.

A Comissão especial, chamada a responder ao ofício de D. Pedro, reconhecia em seu parecer a ocorrência de abusos no Tamoio e na Sentinela, assim como em outros, mas acreditava que isso se devia à falta de legislação especial para o assunto, e por isso

\footnotetext{
${ }^{76}$ ACD, 11/11/1823, página 402.

${ }^{77}$ Idem.
} 
propunha que se suspendessem os debates do projeto de Constituição para encaminhar com urgência a lei de liberdade de imprensa ${ }^{78}$. E, numa clara tentativa de harmonização, reconhecia até mesmo a possibilidade de impor algumas restrições à liberdade de imprensa enquanto não se pusesse a lei em execução, caso o governo achasse necessário $^{79}$. Como não especificava quais deveriam ser essas limitações, deixou um grande espaço aberto à discricionariedade do poder executivo. Esse foi o único momento em que o parlamento sugeriu abertamente que se negociasse com o poder executivo as premissas da livre expressão do pensamento, em nome da pacificação de suas relações, indicador importante da magnitude da crise que se instaurara na Corte.

Antonio Carlos levanta-se para discursar contra o parecer. Em sua opinião, não cabia à Assembléia julgar se houve ou não abuso por parte dos periódicos, e sim ao governo tomar as devidas providências, chamando os acusados ao júri. Talvez insistisse nesse ponto por saber que dificilmente condenavam-se jornalistas. Além disso, pôs-se contra a sugestão do estabelecimento de medidas restritivas à imprensa. Vergueiro, na qualidade de membro da comissão, responde que a decisão de propor as restrições foi julgada politicamente pertinente (ratificando a tentativa de conciliação com $o$ executivo).

Ainda assim, a Assembléia foi dissolvida. A pressão exercida pelos militares ia ao encontro das pretensões autoritárias de D. Pedro, que outras vezes já havia se irritado com as tentativas dos deputados de limitar 'demasiadamente' suas prerrogativas constitucionais e não deixou passar a chance de retomar a liderança do processo constituinte.

O projeto elaborado pela comissão de constituição da Assembléia tornou-se lei por decreto em 22 de novembro de 1823. O imperador atribuía à imprensa a culpa pelos eventos anárquicos de que tinha sido palco o Rio de Janeiro ${ }^{80}$; a justificativa do decreto lembrava que, apesar da liberdade de imprensa ser um dos mais firmes sustentáculos do governo constitucional, seu abuso levaria ao abismo da guerra civil e da anarquia. Não

\footnotetext{
${ }^{78}$ O segundo parecer da comissão foi elaborado com a substituição do Barão de Santo Amaro, que havia pedido dispensa da sessão antes da uma hora da manhã, alegando doença, e Andrada e Silva, que julgou não ser apropriado participar da discussão por ser um dos argüidos por D. Pedro. Em seus lugares entraram Manuel Ferreira da Câmara, deputado por Minas Gerais, e Francisco Carneiro de Campos, da Bahia.

79 Segundo depoimento do ministro do Império, José Joaquim Carneiro de Campos (Marquês de Caravelas), essa seria uma das reivindicações das tropas que se levantaram ofendidas pelos periódicos 'incendiários' que atacavam D. Pedro. A segunda era que os irmãos Andrada fossem destituídos de seus cargos na Constituinte. ACD, 11/11/1823, página 407.

${ }^{80}$ Referindo-se ao espancamento de Pamplona.
} 
se pretendia, segundo o texto, ofender o direito que tinha todo cidadão de expressar livremente seus pensamentos, mas sim que a liberdade de imprensa servisse "somente de dirigi-lo para o bem, e interesse geral do Estado, único fim das sociedades políticas" ${ }^{\prime 81}$.

A lei mantinha as regras para o julgamento dos delitos de imprensa, e o corpo de jurados foi aumentado para 60 pessoas, das quais nove seriam sorteadas para o conselho julgador. A hierarquia da responsabilidade continuava a mesma do último decreto de $\mathrm{D}$. João, e agora o impressor era obrigado a estampar seu nome na capa das suas publicações, sob pena de multa de $50 \$ 000$.

Foram também estabelecidas penas novas e mais pesadas, atribuídas de acordo com a gravidade do delito cometido. $\mathrm{O}$ crime de maior gravidade previsto era $\mathrm{o}$ incitamento à rebelião, cuja pena era 10 anos de degredo e $800 \$ 000$ de multa; em seguida vinham os ataques ao sistema de governo adotado pela nação e à Assembléia Nacional ou ao chefe do executivo, punidos com cinco anos de degredo e 500\$000 de multa e três anos de degredo mais $400 \$ 000$ de multa, respectivamente. Ainda eram passíveis de pena a provocação de desobediência às leis ou às autoridades e delitos contra a religião cristã, também sofrendo degredo e pagamento de multa. Protegendo os servidores do estado, era previsto também que a imputação de fatos caluniosos a funcionários públicos (em função de seu ofício) sem que se pudesse provar sofresse pena de seis meses de prisão e multa de $200 \$ 000$ a 1:000\$000, conforme a gravidade da calúnia, o emprego do caluniado e as posses do caluniador. Contra particulares, os crimes eram as calúnias e injúrias ${ }^{82}$. As primeiras eram punidas com três meses de prisão e multa de $50 \$ 000$ a 400\$000; as últimas, com multa de 50\$000.

Duas semanas antes da outorga da Constituição, em 8 de março de 1824, nova devassa é ordenada por D. Pedro, na pessoa de seu ministro Clemente Ferreira França, ex-deputado da Constituinte. O preâmbulo dizia que, como os inimigos do Império não deixassem de

“empregar todas as suas forças para cavar a ruína do mesmo, incutindo terror nos ânimos incautos por meio de proclamações incendiárias, e pasquins insolentes, concebidos no espírito das cartas, e mais papéis inclusos, que só tendem a perturbar a ordem e tranqüilidade pública, e sobretudo atentar contra o

\footnotetext{
${ }^{81}$ Coleção das leis do império, 1823

${ }^{82}$ Calúnia: falsa imputação a alguém dum fato definido como crime; difamação. Injúria: ofensa à dignidade ou decoro de alguém.
} 
liberal sistema e governo geralmente abraçado, e por em dúvida a constitucionalidade, de que tenho dado as mais exuberantes provas à face do Brasil inteiro" 83 ,

o imperador via-se na necessidade de exigir do Conde Regedor da Casa da Suplicação que iniciasse a investigação dos suspeitos, inquirindo testemunhas e nomeando um ministro e um escrivão probos e capazes, de sua inteira confiança, para que os delitos fossem rápida e sumariamente julgados.

Aí se revela o espaço dos jornais onde se inseriam as maiores provocações ao poder político: a seção de correspondências e "papéis inclusos", provavelmente aquela intitulada "a pedidos", normalmente a mais violenta dos jornais por conta do anonimato garantido pelo uso de pseudônimos e da pretensa irresponsabilidade dos autores por elas ${ }^{84}$. Por conta deles, também, é difícil precisar se se trata de contribuição espontânea dos leitores ou de texto ditado pelo próprio redator. Mas mais do que isso, importa notar que a ordem imperial dirige-se contra aqueles que questionavam a orientação política de D. Pedro, certamente acusando seu despotismo frente à dissolução da assembléia constituinte.

A rápida convocação de uma comissão responsável pela elaboração da Constituição não foi suficiente para aplacar os ânimos exaltados pela dissolução da constituinte, e tal medida, somada à orientação centralista da Carta outorgada, comprometeu muito o relacionamento do governo central com as elites provinciais, ansiosas por uma constituição que lhes garantisse autonomia ${ }^{85}$ - o exemplo cabal, naturalmente, é a revolta de Pernambuco de 1824, que se irradia para outras províncias do nordeste e proclama a independência da área que chamou de Confederação do Equador, cuja repressão foi muito custosa para o Império.

Na constituição de 1824 somente foi enunciado o princípio geral da liberdade de imprensa:

"Todos podem comunicar os seus pensamentos, por palavras, escritos, e publicálos pela Imprensa, sem dependência de censura; contanto que hajam de

\footnotetext{
${ }^{83}$ Coleção das Leis do Império, 8/3/1824.

${ }^{84}$ Nem sempre respeitada: eram comuns, no parlamento, as queixas a respeito de determinadas cartas insertas neste ou naquele jornal, seguidas de pedidos para que fossem pronunciados pelos abusos que elas continham. A indignação não parece gratuita pois, obviamente, as contribuições de leitores passavam pelo crivo e edição do redator, que selecionava os trechos mais adequados à orientação política de sua folha. Sobre este tema, conferir a dissertação de Luciano Silva Moreira, Imprensa e Política: espaço público e cultura política na província de Minas Gerais, 1828-1842, Belo Horizonte, UFMG, 2006, especialmente o $3^{\circ}$ capítulo da parte II.

${ }^{85}$ Miriam Dolhnikoff, op. cit, pág. 56.
} 
responder pelos abusos, que cometerem no exercício deste Direito, nos casos, e pela forma, que a Lei determinar" 86 .

Como vigorava o projeto apresentado na Constituinte, em 25 de maio deste ano é expedida ordem para que se procedesse às eleições dos corpos de jurados que seriam responsáveis pelo julgamento dos casos de abuso da liberdade de imprensa ${ }^{87}$. Em 28 de setembro do ano seguinte, novo decreto ordena a convocação dos juízes eleitos, a fim de que se realizassem os procedimentos para a instalação dos júris ${ }^{88}$.

A fim de tornar efetiva a aplicação da lei, saem decisões do ministério da Justiça, em 21 de julho de 1825, nesse sentido. A primeira ordenava a impressores e administradores de tipografias da Corte que enviassem um exemplar de todos os periódicos que fossem publicados ao desembargador João José da Veiga, então "promotor fiscal dos excessos da liberdade de imprensa". A decisão seguinte, dirigida ao Conselheiro Juiz interino da Alfândega, mandava que também fosse a ele remetida uma relação dos livros e outros impressos despachados, com os nomes dos seus importadores, para que pudesse verificar a existência de abusos nos impressos que se produzissem fora da Corte, e foi originada de reclamação do próprio Veiga, de que não tinha meios para conhecer o que se escrevia fora do Rio de Janeiro, não podendo, dessa forma, iniciar os processos contra os abusos.

Apesar de não constar da relação de leis e decisões do governo a nomeação de outros funcionários que ajudassem na verificação, o número de jornais publicados na Corte à época - aproximadamente $\mathrm{dez}^{89}$, e nem todos diários, revela que a tarefa era exequíivel por uma pessoa só. Ainda assim, muito “abuso" podia passar impune após sua publicação: são freqüentes as queixas dos deputados, desde a Assembléia Constituinte, como se viu, e nas sessões legislativas a partir de 1826, de que os promotores fiscais ou mesmo o governo dessem mais atenção a este ou àquele artigo, que infringia alguma das disposições da lei, em detrimento de outros considerados mais criminosos. O mais comum era que denunciassem periódicos por eles classificados como "absolutistas", que insultavam especialmente a Câmara dos Deputados e pregavam uma distribuição dos poderes que privilegiasse o Imperador, o que evidencia a "seletividade" com que eram examinados e pronunciados os jornais pelos promotores fiscais, não só da Corte como das províncias, pois muitas das denúncias eram de folhas de outros lugares.

\footnotetext{
${ }^{86}$ Constituição do Império do Brasil, capítulo $8^{\circ}$, artigo 179, parágrafo IV.

87 Coleção das leis do Império, 25/5/1824.

${ }^{88}$ Idem, 28/9/1825.

${ }^{89}$ Marco Morel, Transformações dos espaços públicos, op. cit, página 204.
} 
Neste primeiro momento, então, observa-se que, apesar da liberdade de imprensa constituir um ponto importante do discurso liberal evocado durante os movimentos para a independência, e também depois, nas discussões sobre a configuração das instituições do novo império, a atividade jornalística da oposição ainda sofria perseguições do ministério, que tinha ao seu alcance a edição de medidas extralegais para a instauração de processos policiais e judiciais sumários. Contudo, ao recorrer a esse expediente para silenciar seus opositores, o governo levantava grande oposição no parlamento, indispondo-se com parte da elite, desejosa de ver concretizado no Brasil a livre expressão de seu pensamento. Dessa forma, ainda que a repressão fosse possível, não estava isenta de altos custos políticos para o Imperador e seus ministros. 


\section{Capítulo 3}

\section{O parlamento e a imprensa}

Em 1826 inicia-se a vida parlamentar brasileira. Segundo Thomas Flory, a reunião da primeira assembléia legislativa regular prefigurou uma "segunda independência" do Brasil. Após praticamente três anos sem um poder representativo que fizesse frente ao governo de D. Pedro, o Legislativo voltava a atuar e lentamente tornouse um espaço de organização de oposição ao governo, retomando alguns itens do debate interrompido com a dissolução da Constituinte em 1823. Os parlamentares, articulados no grupo denominado liberal moderado, centraram suas críticas no modelo político instaurado pela constituição de $1824^{1}$.

Para Flory, o período efetivamente revolucionário da independência brasileira se dá entre os anos de 1827 e 1837, momento em que se desmontam efetivamente as instituições coloniais para dar lugar a novas. O primeiro ano é marcado pela aprovação, na Câmara dos Deputados, da lei que instituía o juizado de paz eletivo, medida que descentralizava consideravelmente o poder judiciário, enfraquecendo a influência exercida pelo governo central. Este sucesso parlamentar só foi possível graças à coalizão entre moderados e radicais, e tal "frente de oposição" teria empurrado o imperador para uma situação cada vez mais defensiva, exacerbando ainda mais o conflito entre D. Pedro e os deputados.

O início das sessões legislativas criou condições para o reavivamento da imprensa, cuja circulação se debilitara consideravelmente após a dissolução da Assembléia Constituinte, dada a perseguição que se instaurou a alguns de seus membros (especialmente os Andradas) e o decorrente clima de insegurança, e provavelmente também devido à devassa instaurada em 1824.

O periódico liberal moderado mais importante do período foi a Aurora Fluminense, redigido por Evaristo da Veiga, figura importantíssima da política imperial até a segunda metade da década de 1830. Como jornalista e deputado - cargo que exerceu por três legislaturas seguidas (1830 a 1838) -, encetou grande oposição ao governo durante o I Reinado e apoiou os governos regenciais, sempre defendendo as prerrogativas do poder legislativo. Seu ativismo lhe renderia, além do prestígio e dos

\footnotetext{
${ }^{1}$ Thomas Flory, op. cit.
} 
sucessivos mandatos, um atentado a tiros em 1832, do qual escapou sem ferimentos graves, sendo que nunca foi descoberto o mandante ${ }^{2}$. Esse não seria o único caso de violência contra jornalistas após o início da rotina parlamentar, como se verá; contudo, nada autoriza a imaginar que se tratasse de perseguição oficial ou extra-oficial do governo.

Outro jornal liberal moderado de grande importância foi a Astréa, redigido por Antonio José do Amaral e José Joaquim Vieira Souto. Os dois elegeram-se deputados gerais pela província do Rio de Janeiro na legislação de 1830-33, e o segundo reelegeuse para a seguinte, aproveitando-se especialmente do prestígio que amealharam com um dos periódicos mais longevos da Corte (perdendo apenas para a Aurora) ${ }^{3}$. A folha teria sofrido a perseguição de agentes do governo, que lhe impunham uma aplicação rigorosa da lei de imprensa então em vigor. "Entre novembro de 1826 e maio de 1828 seu redator foi denunciado e respondeu pelo menos a onze processos, invariavelmente sem criminalidade, como noticiava ufano". Apesar do desejo governamental de ver o redator punido e com isso acabar com o jornal, pôde contar com "Júris permeáveis às idéias do tempo e que não receavam absolver o querelado" ${ }^{4}$. Mais uma vez o judiciário contrariava o governo, absolvendo um jornalista acusado de abusar da liberdade de imprensa.

Com o crescimento da oposição e de sua presença pública, e com a dificuldade de estancar o fluxo de suas publicações pela via legal, o governo via-se obrigado a utilizar a mesma arma e, assim, ajudava na criação de outros jornais, financiando e protegendo suas atividades. A mais famosa das folhas governamentais da época, sem dúvida, foi a Gazeta do Brasil, redigida pelo português João Maria da Costa a mando de Francisco Gomes dos Santos, conselheiro e amigo de D. Pedro. Sobre a folha, diz Otávio Tarquínio que tinha como objetivo principal solapar o prestígio da Câmara dos Deputados, injuriando os deputados "independentes", Além disso, travava polêmicas violentas com outros jornais, especialmente a Aurora Fluminense e a Astréa.

\footnotetext{
${ }^{2}$ Marcello Basile, op. cit, página 27.

${ }^{3}$ Idem, página 28.

${ }^{4}$ Otávio Tarquínio de Sousa. Fatos e personagens em torno de um regime. Belo Horizonte: Itatiaia, São Paulo: EDUSP, 1988. Citações à página 170.

${ }^{5}$ Otávio Tarquínio de Sousa. A vida de D. Pedro I, op. cit, tomo II, página 721.
} 
Além da Gazeta, o governo contaria com outros jornais para sua defesa. O mais importante foi o Diário Fluminense, com o qual colaboravam frequentemente os ministros do Estado e, de acordo com Sodré, até mesmo o Imperador ${ }^{6}$.

\section{O debate do projeto de 1826}

Uma das primeiras preocupações da câmara recém-instalada foi discutir uma lei sobre os abusos da liberdade de imprensa. O texto foi aprovado no ano seguinte e enviado ao senado para apreciação, de onde volta com penas mais amenas e outras emendas marginais, e em agosto de 1830 é aprovado. A sanção imperial é de 20 de setembro deste ano ${ }^{7}$.

Em 10 de junho de 1826, Joaquim Gonçalves Ledo - antigo opositor do governo imperial, que com a queda de José Bonifácio garante seu lugar junto ao imperador apresenta à câmara projeto que julga de urgente necessidade, a respeito da liberdade de imprensa. Ao contrário do que aconteceu durante a Constituinte, a iniciativa não encontra oposição entre os parlamentares, que reconhecem prontamente a necessidade de legislação sobre o assunto.

O preâmbulo de seu discurso elogia o sistema representativo como o único capaz de fazer a felicidade e a prosperidade das nações, oferecendo a aliança entre força, sabedoria e liberdade, mas lembra que para sua consolidação é necessária a existência de "liberdade de imprensa, e jurados no crime; são estes os grandes pilares, sobre que se estriba todo o sistema (...); onde a opinião pública não pode enunciar-se livremente (...)

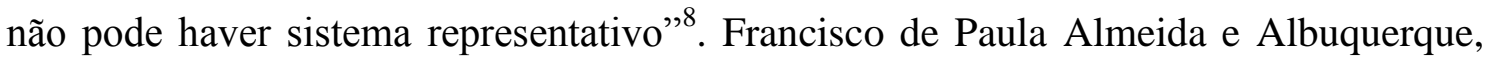
deputado pernambucano, também reforça a importância política da imprensa durante as primeiras discussões do projeto: “A liberdade da imprensa é o verdadeiro sustentáculo da liberdade civil e política. Desde que se acaba a liberdade de imprensa, perde-se tudo"9. Como se vê, a existência da liberdade de imprensa era identificada à consolidação do regime constitucional-representativo, e a defesa da liberdade de expressão pública nesses termos é claramente relacionada à recusa de instauração de

\footnotetext{
${ }^{6}$ Nelson Werneck Sodré, op. cit, página 111.

${ }^{7}$ Coleção das Leis do Império, Lei de 20 de setembro de 1830, Sobre os abusos da liberdade de imprensa.

${ }^{8}$ Anais da Câmara dos Deputados (daqui em diante, ACD), sessão de 10/6/1826, pg. 90

${ }^{9} \mathrm{ACD}, 22 / 7 / 1826$, página 285
} 
qualquer tipo de censura prévia dos impressos - expediente totalmente identificado com as práticas absolutistas.

Embora à primeira vista o objetivo do projeto pareça ser o de salvaguardar as prerrogativas dos escritores públicos, sua preocupação central logo se mostra ser a regulação da liberdade de imprensa de modo a limitar seu exercício, pois adiante Ledo completa: "Nós não temos tido, nem temos liberdade de imprensa: o que tivemos e

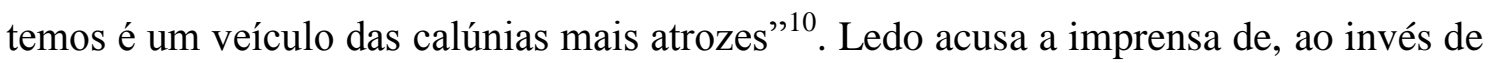
obrar pela indústria e progresso nacional, melhorando as faculdades intelectuais dos cidadãos, prestar-se a instrumento da ociosidade e da depravação, utilizando-se da calúnia, da ignorância e, o pior de tudo, do servilismo. Pintado o quadro, apresenta o projeto que considerava abuso da liberdade de imprensa: 1) ataques diretos ao sistema monárquico representativo; 2) injúrias contra o imperador e sua família; 3) concitações diretas ao povo para rebelar-se contra as leis e contra as autoridades; 4) ataques diretos à religião do Estado; 5) insultos e injúrias aos diferentes cultos permitidos no império; 6) denúncia pública de crime cometido por particular, sem a devida capacidade de prova; 7) publicação de acontecimentos referentes à vida privada do cidadão; 8) publicação de censuras relativas à vida privada do funcionário público. Era responsável o autor e, depois dele, o "apresentante" do impresso. Não se podendo conhecer nenhum dos dois, a hierarquia continuava com o impressor, o editor e o vendedor ou distribuidor. Todos os crimes de abuso deveriam ser julgados pelo tribunal dos jurados. Lido o projeto, a urgência é requerida e aprovada, e em 6 de julho volta ao plenário para ser discutido. Assim, Ledo expressa visão em nada diferente de seu antigo inimigo, Bonifácio, ao descrever o que considerava abuso de imprensa e propor uma lei que punisse aqueles que o praticassem. Ambos, em termos teóricos, estavam no campo liberal e, no século XIX, era legítima a preocupação em penalizar legalmente os jornalistas que com seus escritos colocassem em risco a ordem vigente. Concepção que obviamente favorecia o governo, pela fluidez do conceito de abuso, mas em um contexto em que não podia mais evitar o convívio com uma imprensa de oposição.

Não era, entretanto, apenas o regime e a ordem pública que se pretendia proteger, mas também o individuo. Neste dia, Ledo inicia a discussão dizendo que toda liberdade precisa de limites, e especialmente aquela que atingia o cidadão, pois

\footnotetext{
${ }^{10}$ ACD, idem, ibidem.
} 
"a nódoa que pela imprensa se inflige na reputação do homem não fica somente no território da pátria, ou da nação; não se contém dentro do presente, gira o mundo, e remonta-se à posteridade" $"$.

Sua preocupação em proteger o cidadão de bem das calúnias lançadas pela imprensa é ecoada por praticamente todos os parlamentares, que reconhecem o direito do cidadão de manter sua honra privada livre de máculas.

Muito mais importante que a honra privada, porém, era a manutenção da ordem social; é grande o poder de mobilização creditado à imprensa pelos deputados: julgamna capaz de provocar sedições, de animar o povo contra o governo e as autoridades constituídas, e por isso é necessária a sua regulação atenta. A fala do magistrado José Bernardino Batista Pereira, deputado do Espírito Santo, ilustra bem sua sanha persecutória e a de alguns seus colegas:

"um escritor, que pensa e que depois de muito tempo e madura reflexão faz imprimir e aparecer idéias contrárias ao sistema do governo, abraçado e jurado por toda a nação e seu chefe, cometendo tal crime, não pode deixar de merecer penas muito fortes. Toda a indulgência a seu favor seria mal fundada: a impunidade animaria a novos atentados, e seguir-se-ia a desordem $e$ a dissolução dos vínculos sociais. A história nos apresenta as suas páginas manchadas com tais horrores" 12 .

Mais à frente, o mesmo deputado serve-se de boa metáfora para reforçar seu ponto:

"A árvore da liberdade apenas está plantada; ainda não apareceu seu desenvolvimento; é preciso arrancar os arbustos parasitos, que estão em torno dela, e qual será o método? Castigar o homem que quiser destruí-la"13.

O deputado verbaliza, aqui, o receio sempre presente de um levante popular contra as instituições estabelecidas; no entanto, não se acreditava que o povo, por si só, fosse capaz de tal iniciativa por conta própria - precisaria, para tanto, ser enganado pelos opositores do regime constitucional representativo, instigado à violência e guiado até a destruição da autoridade. Encontra-se, assim, o sentimento dos parlamentares em relação à população brasileira: inculta e despreparada para discernir entre o que melhor correspondia aos seus interesses. Cabia a eles, e ao Estado em geral, tomar as providências para que fosse instruída no que lhe era benéfico e, enquanto isso não se

\footnotetext{
${ }^{11}$ ACD, sessão de 6/7/1826, página 55

${ }^{12} \mathrm{ACD}$, sessão de 6 de julho, página 63 , grifo meu.

${ }^{13}$ ACD, idem, página 69.
} 
concretizasse, deveriam garantir que não tomasse contato com idéias perniciosas ao "bem-estar nacional". Esse é um ponto que não levanta discordância; e as palavras de Batista Pereira são, por isso, exemplares:

“a nossa população ainda está pouco instruída (se assim me é permitido explicar) no que melhor convém para sua felicidade; e portanto lendo estes escritos, pode abraçar a sua doutrina: e os resultados devem ser funestos para ela mesma" ${ }^{, 14}$.

Somando à ignorância da população a disposição dos inimigos do sistema representativo de buscar seu apoio por meio da imprensa, chega-se à necessidade de proibir enfaticamente os ataques à forma de governo adotada. Nas palavras de José Lino Coutinho,

“os problemas políticos (...) não são resolvidos de uma só maneira por todos os homens (...). É preciso que caracterizemos o nosso sistema como uma verdade, contra a qual não se pode invectivar; é preciso que sobre tal objeto cesse a liberdade de escrever, e quem entender ao contrário que vá escrever fora daqui. Entre nós não é lícito escrever contra o sistema atual (...); é preciso que santifiquemos esse sistema como o melhor, e como uma verdade infalível"15.

E Gonçalves Ledo corrobora o discurso de Lino:

"Se acaso fica vedada esta faculdade para atacar e invectivar o sistema monárquico constitucional, é porque a nação o tem adotado, é porque é a expressão da vontade geral, é porque é o único capaz de fazer a verdadeira felicidade da nação"16.

É curiosa a relação que aqui se estabelece: assegura-se a liberdade dos cidadãos de exporem livremente seus pensamentos a respeito do sistema político, desde que não o ataquem frontalmente ou especulem a respeito das consequiências de sua adoção para o país. Essa concepção de liberdade era a defendida por homens próximos a D. Pedro, que certamente viam no ataque ao sistema uma ofensa ao imperador, ameaça, no limite, à sua própria existência, confundida com a do Império.

O medo de um levante popular iniciado pela imprensa encontra sua expressão máxima na proposta de endurecimento da pena (que já previa degredo e prestação de serviços forçados) àqueles que concitassem revoltas, feita por outro magistrado, o

\footnotetext{
${ }^{14}$ ACD, idem, página 64.

${ }^{15} \mathrm{ACD}$, idem, página 67

${ }^{16}$ ACD, idem, página 66.
} 
deputado pelo Rio de Janeiro José Clemente Pereira ${ }^{17}$. Lembrando que o país ainda contava com inimigos do sistema constitucional - absolutistas e democráticos - e que “ambos valer-se-ão da liberdade de escrever, [sendo] preciso estabelecer penas severas para prevenir e corrigir os ataques por este lado" 18 , sugere que o escritor que induzisse revolta por meio de seus escritos fosse condenado à morte: "Aquele que ataca o sistema de governo e é causador por isso de uma sedição, não pode receber pena menor do que a morte" ${ }^{, 19}$. No caso de não se suceder uma rebelião ao ataque, caberia a expulsão do país: "Ora, eu entendo que aquele cidadão que atenta contra a forma de governo que a sua pátria adotou é indigno de gozar dos benefícios desse mesmo governo; é portanto melhor exterminá-lo e privá-lo dos bens que lhe assegura a sociedade do que impor-lhe outro gênero de castigo"20.

Ele também propõe diversas emendas que, se aceitas, ampliariam a discricionariedade da interpretação do júri para acusações, como é o caso da sugestão de supressão do adjetivo diretos, referente aos "ataques contra o sistema monárquico representativo" e à religião do Estado:

"nenhum dos mesmos senhores advertiu nos inconvenientes que na prática se pode seguir da palavra diretos que se acha ligada ao substantivo ataques. Ora, nada mais fácil do que qualificar como indireta uma ação, que na realidade tende diretamente a qualquer fim proposto (...) Portanto sou de parecer que se deixe esta qualificação ao juízo do mesmo júri. Eles hão de julgar se houve ou não ataque, se houve ou não criminalidade" ${ }^{21}$.

No geral, Clemente Pereira situa-se num dos extremos da polarização da questão, e nenhum outro deputado mostra-se tão coerentemente rigoroso como ele.

Como seria de se esperar, não havia consenso na Câmara sobre o assunto. Contra os defensores de um endurecimento do projeto, levantaram-se aqueles que advogavam uma liberdade de imprensa mais ampla do que a originalmente contemplada. É o caso, por exemplo, de Bernardo Pereira de Vasconcelos, quando afirma que "aquele que atacar o sistema representativo entre nós não deve ter pena alguma pelos efeitos que daí se podem seguir; porque se houver quem o ataque também

\footnotetext{
${ }^{17}$ Suas posições políticas na Câmara dos Deputados seriam valoradas por D. Pedro, que em 1828 o nomearia ministro do Império. Nessa posição, Clemente Pereira ordenaria a suspensão das garantias constitucionais em Pernambuco, a fim de estabilizar a política da província, o que lhe valeria, no ano seguinte, grandes reprimendas e quase lhe custa o mandato como deputado.

${ }^{18}$ ACD, 6 de julho de 1826, página 69.

${ }^{19}$ ACD, idem, página 64.

${ }^{20} \mathrm{ACD}$, idem, ibidem.

${ }^{21}$ ACD, 6 de julho de 1826, página 64.
} 
há de aparecer quem o defenda e sustente" ${ }^{, 22}$; em outra ocasião, repete o corolário: "Senhores, as nações têm um grande meio de prevenir os males de tais escritores, é o de outros escritores. Nada de penas" ${ }^{23}$. Também é essa a posição de Nicolau Vergueiro, que sustenta que

"uma vez que todos podem escrever, e a liberdade é de fato geral para todos, há de infalivelmente vencer a razão, justiça e a verdade. O mal aparece quando só há liberdade para uns escritores, e não para os outros. Então é que se pode persuadir um erro ao público, que não lê outros escritores de opinião contrária (...). Os escritos são sempre posteriores às verdadeiras causas das revoluções, [que] são os erros dos governos."

No mesmo sentido, Almeida e Albuquerque diz:

"devemos confessar que os maiores males que provêm à sociedade pela imprensa nascem mais da proibição do que dos abusos dela (...). Devemos pois atender não tanto a evitar os ataques que se queiram fazer ao sistema pela imprensa, como manter a liberdade, por um escritor comprado para infamar o sistema aparecerão dez que livremente tomem a sua defesa." 24 .

Essas são posições que evidenciam uma preferência pela abordagem mais permissiva da atividade periodística, e maior coerência com o princípio iluminista da importância do debate para o alcance da verdade social. E, para além de clivagens ideológicas, torna-se evidente a divisão política da Câmara: os deputados que discursam nesse sentido faziam parte da oposição parlamentar que se formou contra o governo imperial, e lutava para firmar a preponderância do legislativo face ao executivo. Por outro lado, os defensores de limites mais estreitos para a imprensa eram mais próximos ao imperador, e provavelmente a iniciativa de apresentação do projeto tenha sido tomada a fim de conter as críticas à sua atuação, que então choviam pelos jornais.

A divergência era ao mesmo tempo de postura política e de concepção. Os governistas enfatizavam a necessidade de criação de um sentimento nacional, uno, em torno das instituições que se erigiam, e por isso advogavam a imposição de limites à liberdade de expressão, ressaltando o potencial destrutivo e desagregador da imprensa. A oposição, por sua vez, tendia a valorizar mais a crítica e o debate, defendendo, assim,

\footnotetext{
${ }^{22}$ ACD, sessão de 6 de julho de 1826, página 65.

${ }^{23} \mathrm{ACD}$, sessão de 9 de junho de 1827, página 42.

${ }^{24}$ ACD, sessão de 6 de julho de 1826, página 71, ambas as citações.
} 
que a repressão seria a verdadeira ameaça à coesão nacional e às instituições representativas.

Bernardo Pereira de Vasconcelos é quem opõe resistência sistemática ao projeto, encaminhando diversas emendas que suavizavam as penas e aumentavam o espectro de atuação do escritor em relação ao projeto inicial, tendo quase todas rejeitadas. Uma consideração mais precisa de sua atuação revela preocupação com a garantia do direito de resposta ao ofendido em casos de injúria e calúnia, no mesmo jornal que veiculou a ofensa, como contrapartida da inexistência de condenação penal para o jornalista. $\mathrm{O}$ parlamentar demonstra apreciar somente duas garantias oferecidas pelo projeto, para além das que tratam da defesa da honra privada do cidadão: a que protege a câmara (especialmente a temporária) de ataques que possam voltar contra ela a opinião pública, e a que permite ampla discussão a respeito da atuação dos funcionários públicos (como se verá adiante), por conta da batalha que então se travava para aumentar a força do poder legislativo frente ao executivo e por sua concepção da função da imprensa.

O receio de que a imprensa fosse capaz de organizar o povo brasileiro em torno de um projeto de dissolução do Estado como então se conhecia ${ }^{25}$ não pode deixar de despertar curiosidade, especialmente quando se considera que era pequena a parcela de cidadãos alfabetizada, capaz de compreender as mensagens impressas. Esse fato parece confirmar a idéia de Marco Morel, para quem existia uma convivência dúbia entre as sociabilidades moderna e do Antigo Regime, de forma que

"havia cruzamentos e intersecções entre as expressões orais e escritas, entre as culturas letradas e iletradas. A leitura, como nos tempos então recentes do Antigo Regime, não se limitava a uma atitude individual e privada, mas ostentava contornos coletivos. Nesse sentido, a circulação do debate político ultrapassava o público estritamente leitor" 26 .

Essa suposição ameniza a idéia de que a circulação das idéias vinculadas pela imprensa fosse restrita às camadas ricas e letradas, pois torna factível a inclusão das camadas que, mesmo iletradas, tinham acesso aos espaços onde se liam e discutiam notícias e editoriais.

Arnaldo Contier cita Antônio Cândido para, evocando uma característica marcante da nascente literatura nacional, demonstrar o mesmo:

\footnotetext{
${ }^{25}$ Que, se não foi expresso pela maioria dos deputados, ao menos encontrou nela grande receptividade.

${ }^{26}$ Marco Morel, op. cit, página 45.
} 
"a ação dos pregadores, dos conferencistas de academia, dos glosadores de mote, dos oradores de comemorações, dos recitadores de toda hora, correspondia a uma sociedade de analfabetos, ou pouco afeitos à leitura. Deste modo, formouse, dispensando o intermédio da página impressa, um público de auditores, muito maior do que dependesse dela e favorecendo, dir-se-ia mesmo requerendo no escritor certas características de facilidade e ênfase, certo ritmo oratório que passou timbre de boa leitura e prejudicou, entre nós, a formação dum estilo realmente escrito para ser lido. A grande maioria de nossos escritores, em prosa e verso, fala de pena em punho e prefigura um leitor que ouve o som de sua voz brotar a cada passo por entre linhas". ${ }^{27}$ (grifo meu).

De qualquer modo, quando se trata de liberdade de imprensa, o analfabetismo não parece ser uma questão para os parlamentares. Segundo Hélio Seixas Guimarães, não existia no Brasil, até 1872 (data de conclusão do primeiro censo nacional), uma noção exata das dimensões do analfabetismo. Essa informação abalou profundamente os ânimos de escritores, segundo Guimarães, e provavelmente também o dos políticos. $\mathrm{O}$ avanço da instrução pública e das letras no país era constantemente alardeado como medíocre e insuficiente pelos deputados, mas por algum motivo seu tamanho real era subestimado $^{28}$. Essa pouca sensibilidade é demonstrada pela discussão sobre as gravuras sediciosas. A possibilidade de que gravuras pudessem provocar os mesmos tumultos que os impressos chega a ser considerada por alguns, como Batista Pereira:

"o lápis do caricaturista é um instrumento muito mais perigoso do que a imprensa; o quadro é a imagem exata da cena, o escrito é uma descrição imperfeita; um hábil artista comunica ao espírito mais simples quanto quer; e um escrito em frase figurada disfarça e encobre o crime, deixando contudo maculada a honra do ofendido" 29.

Vasconcelos também era da opinião de que "as gravuras podem ser tão perigosas quanto os escritos, porque imprimem as idéias no espírito com maior força, e obram igualmente sobre todos" ${ }^{30}$. Os dois deputados chegam perto, mas não tratam a questão em termos de maior acessibilidade das imagens a uma população majoritariamente analfabeta.

\footnotetext{
${ }^{27}$ Antônio Cândido, "O escritor e o público" apud Arnaldo Contier, Imprensa e ideologia em São Paulo. Petrópolis: Vozes, 1979, pg. 38.

${ }^{28}$ Hélio de Seixas Guimarães. Os leitores de Machado de Assis. O romance machadiano e o público de literatura no século XIX. São Paulo: Nankin Editorial: Edusp, 2004.

${ }^{29} \mathrm{ACD}$, sessão de 8 de junho de 1827, página 34.

${ }^{30} \mathrm{ACD}$, idem, página 36.
} 
O deputado baiano Miguel Calmon du Pin e Almeida faz uma observação curiosa para justificar seu voto na emenda que previa penas mais brandas aos desenhistas agitadores do que aos escritores sediciosos: "acrescentarei, de passagem, que elas [gravuras] são perigosas somente entre povos dispostos à revolução, ou entre povos mal governados" ${ }^{31}$, o que não seria o caso do Brasil. Por fim, também Lino Coutinho minimiza o potencial subversivo das imagens:

"ainda quando hajam gravuras sediciosas, delas não podem resultar tantos males como dos impressos. Já mostrei que a força da palavra era mais forte que a das gravuras, e por isso as penas impostas a essas deviam ser menores" 32 .

Vence essa posição, e as penas para os autores ou impressores de imagens consideradas abusivas acabaram fixadas em metade das previstas para os textos.

Apesar do consenso sobre a necessidade de regular a liberdade de imprensa, mesmo os defensores do projeto reconheciam a inadequação de algumas das suas disposições ao espírito liberal e a necessidade de, no futuro, modificar a lei e ampliar a liberdade. Lino Coutinho, continuando o discurso em que defende a sacralização do sistema representativo, afirma que "Quando ele estiver naturalizado em nosso solo, serei o primeiro a riscar esse artigo; deixarei que digam o que lhes parecer (...). Porém ainda não é o tempo de conceder esta ampla liberdade" ${ }^{33}$. Outro bom exemplo encontra-se na fala de Almeida e Albuquerque:

"Se o nosso sistema estivesse consolidado, eu diria que era desnecessária semelhante cautela, porque estou certo que a liberdade ampla de escrever é o melhor meio de destruir opiniões errôneas, e fazer triunfar a verdade. Porém conheço o estado em que nos achamos por ora, e a necessidade de tomarmos medidas contra os ataques dos inimigos da constituição"34.

Mesmo Vasconcelos reconhece que, não consolidado o sistema, “devem [-se] empregar medidas que não teriam lugar em outra ocasião",35, 36 .

\footnotetext{
${ }^{31}$ ACD, idem, página 35.

32 ACD, idem, página 36.

${ }^{33}$ ACD, sessão de 9 de junho de 1827, página 67.

${ }^{34} \mathrm{ACD}$, idem, página 71.

${ }^{35}$ ACD, 6 de julho de 1826, página 65.

${ }^{36}$ Contudo, durante a terceira discussão do projeto, já em 1827, vale-se de um escritor inglês para embasar sua oposição à aprovação do projeto, revelando sua verdadeira inclinação: "Um célebre escritor inglês, tratando da liberdade de imprensa, diz: aqueles que mais falam nessa liberdade são aqueles que menos a querem; empreguem na discussão de outras matérias o tempo que gastam com esse objeto, [pois] a melhor lei que a este respeito se pode organizar é nenhuma" (ACD, sessão de 1 de junho de 1827, página 9).
} 
Ao esvaziarem a imprensa de sua função de veicular críticas ao sistema político adotado, os deputados revelam suas concepções de qual deve ser a tarefa desempenhada pela "boa imprensa", divididas em duas grandes linhas. A primeira pode ser exemplificada pela fala de Batista Pereira:

"A verdadeira liberdade de imprensa deve tender a salvar a pátria, promover a instrução geral, corrigir os maus costumes, e principalmente formar a opinião pública (...). Por consequiência, a primeira utilidade que se tira da liberdade de imprensa é a formação desta opinião geral, é a instrução da própria nação"37.

Também Gonçalves Ledo, na justificativa de apresentação do projeto, argumenta nesse sentido:

"[a imprensa deve] ocupar-se pelo lado de suas relações com o simples cidadão, em fertilizar o seu trabalho e a sua indústria, em multiplicar a sua riqueza (...) [em] melhorar as suas faculdades intelectuais e físicas (...). [Servir] de precursora da opinião na formação das leis, ou dispondo os espíritos para abraçar sem resistência o bem que se lhes pretende fazer, e [poupar] aos homens o custoso tirocínio dos séculos" ${ }^{38}$.

Era amplamente aceito, por todas as correntes políticas brasileiras, dos liberais exaltados aos áulicos, o papel pedagógico atribuído à imprensa, coerentemente com a avaliação que se fazia do estado primitivo da consciência política do povo. De acordo com o abordado anteriormente, o combate à ignorância popular deveria se dar também pela frente do periodismo, responsabilizado, principalmente, por "amansar" (ou mesmo domar) os ímpetos populares de violência e desobediência.

Segundo Marco Morel,

“Tal convergência era um dos componentes básicos desta época de liberalismo tocado pelas Luzes: a legitimidade dos redatores que se constituíam em agentes propagadores deste esclarecimento em todas as direções. Estes homens de letras apresentavam-se como cidadãos e escritores ativos, como construtores da opinião que almejava levar a sociedade a algum tipo de progresso e de ordem nacional" 39 .

De modo geral, os redatores das folhas, localizados em qualquer ponto do espectro político, buscavam tal papel em nome do esclarecimento e civilização do povo

\footnotetext{
${ }^{37}$ ACD, sessão de 6 de julho de 1826, página 63.

${ }^{38}$ ACD, sessão de 10 de junho de 1826, página 91.

${ }^{39}$ Marco Morel, op. cit. Página 218.
} 
brasileiro, pois também se julgavam possuidores das luzes necessárias para tanto. Wlamir Silva, analisando a atuação dos jornalistas liberais na província de Minas Gerais, afirma que a imprensa foi essencial à "pedagogia política" do liberalismo moderado para o que chama de construção de um "consenso ativo" da sociedade, ou seja, para a amplificação dos projetos políticos do grupo moderado e sua aceitação por outros segmentos sociais ${ }^{40}$. Segundo o autor,

"A difusão das luzes e a dimensão civilizatória permeavam o discurso liberal, pois a instrução era entendida como condição para a formação do cidadão e, assim, a prática política e o aperfeiçoamento da sociedade e do Estado"41.

A ignorância do cidadão em relação aos negócios de Estado não era compatível com o bom andamento do governo num regime representativo - era fundamental, nessa nova ordem, providenciar o conhecimento necessário para que a participação política se desse de maneira ordeira e ao encontro das necessidades do Estado, blindada contra invectivas de demagogos republicanos ou absolutistas.

Os mesmos redatores, dependendo de suas relações com o governo e as câmaras, exerciam também a função a eles atribuída por Vasconcelos: "o maior benefício da liberdade de imprensa é descobrir os erros e crimes dos empregados públicos" e, mais enfaticamente,

“as ações praticadas na vida pública pertencem ao público, podem os escritores analisá-las como julgarem necessário, diga-se o que se disser, impute-se o que se imputar, tudo é lícito, porque isto não tem nada com a vida particular, pois neste caso, ainda que o escritor queira provar os fatos que assoalha há de ser por força condenado, mas quando imputar ao empregado público fatos relativos ao seu ofício, decerto nenhum deve ser castigado, porque determinar o contrário é o mesmo que dizer - não haja liberdade de imprensa - porquanto a liberdade de imprensa não consiste em ataques a este ou aquele indivíduo, mas deve servir para desmascarar as prevaricações dos empregados públicos, e mesmo para se atacarem as leis que saírem desta assembléia quando elas não forem para acudir à necessidade pública e para fazer sua felicidade ${ }^{, 42}$.

\footnotetext{
${ }^{40}$ Wlamir Silva, A imprensa e a pedagogia liberal na província de Minas Gerais (1825-1842). In Neves, Lúcia Maria Bastos, Morel, Marco, e Ferreira, Tânia Maria Bessone. História e imprensa: representações culturais e práticas de poder. Rio de Janeiro: DP\&A,: Faperj, 2006.

${ }^{41}$ Idem, página 43.

${ }^{42}$ ACD, sessão de 22 de julho de 1826, páginas 284 e 187, respectivamente.
} 
A proposta de Vasconcelos era radical, pois advogava a inimputabilidade dos escritores que denunciassem, sem provas, malversações dos funcionários públicos (mesmo sendo falsas - nesse caso, cabia ao funcionário o ônus da prova de sua inocência, mas lhe seria garantido espaço na mesma folha que o imputou para que se defendesse das acusações), pois sendo aprovada a penalização, o resultado seria que "não haver[á] quem escreva, e não havendo quem censure a conduta dos funcionários públicos, (...) acabamos com a liberdade de imprensa"43. Pelo contrário, as medidas a serem tomadas deveriam seguir o sentido de proteger o jornalista contra o poder do funcionário: "Admitindo a emenda [que introduzia a necessidade de prova das acusações], vamos pôr em luta duas pessoas muito desiguais: o pobre escritor com o valente empregado público" ${ }^{44}$. O deputado mineiro buscava garantir que a imprensa continuasse a ser um espaço de contestação ao governo, neste momento ainda visto com muita desconfiança pelos moderados.

José da Cruz Ferreira, magistrado fluminense autor da emenda citada, acompanha a argumentação somente até certo ponto: "É necessário que a liberdade de imprensa sirva para censurar operações do governo e dos empregados públicos, mas com verdade ${ }^{\natural 5}$, no que é seguido por Lino Coutinho. Apesar da defesa de Vasconcelos ser endossada pela maioria dos deputados que falaram nesse sentido e o artigo ter sido aprovado pela câmara sem a emenda proposta, no projeto final consta a condição da prova, inserida pelo senado. De qualquer modo, fica registrada a idéia de que à imprensa caberia fiscalizar a administração pública e denunciar os atos de má gestão de políticos e, principalmente, funcionários do Estado.

É notável a ausência, nessa discussão, da idéia da imprensa como órgão informativo da vontade da nação para os deputados. A preocupação de manter a câmara informada aparece apenas pulverizada em discussões variadas, mas é pequena perto da de manter a população ciente dos seus trabalhos. O 'bem geral' é construído ali e deve difundir-se pelo país por meio da discussão pública de seus atos (encaminhada, evidentemente, em termos decentes) e da distribuição de seus diários. Evidencia-se, então, uma concepção que privilegia a câmara como o primordial espaço de formação do interesse nacional, que não necessita consultar a 'opinião pública' sobre a vontade

\footnotetext{
${ }^{43}$ ACD, idem, página 284.

${ }^{44}$ ACD, idem, ibidem.

${ }^{45}$ ACD, idem, ibidem, grifo meu.
} 
que lhe é externa, pois reúne em si os elementos precisos para garantir a legitimidade de suas decisões.

A terceira discussão do projeto é finalizada em 1827, e então ele é encaminhado para o Senado, onde entra em discussão apenas em maio de 1829. No meio-tempo, em 23 de junho de 1827, a Comissão de Justiça Civil e Criminal da Câmara apresenta ao plenário seu parecer sobre as questões a respeito das dúvidas sobre a interpretação da lei de liberdade de imprensa encaminhadas pelo promotor fiscal dos crimes por abuso da liberdade de imprensa da Corte, João José da Veiga.

A primeira dúvida perguntava se deveriam ser consideradas crimes a infâmia ou injúria dirigidas a uma só das duas câmaras legislativas do Império. Isso porque a lei em vigor, o projeto da Assembléia Constituinte, falava apenas em Assembléia Geral, que era a união das duas Câmaras. Correlata a esta, a segunda pergunta indagava se para realizar-se o abuso que a lei pune era necessário que formalmente se infamasse ou injuriasse a assembléia como um todo, ou se era bastante serem infamados ou injuriados os seus membros.

A terceira questão é a mais reveladora da interpretação que o corregedor tentava aplicar ao decreto de 22 de novembro. Ele perguntava se as infâmias e injúrias dirigidas ao governo e ministério poderiam ser interpretadas como ofensas indiretas ao chefe do poder executivo, ou seja, o Imperador. Por fim, o último ponto indagava se se poderia incriminar aqueles que fizessem circular os discursos de deputados e senadores pelas opiniões ali enunciadas.

O parecer apresentado pela Comissão considerava que era sim aplicável à Assembléia Geral Legislativa, e às câmaras individualmente, tudo quanto se achava disposto a respeito do poder legislativo no decreto. Em relação à segunda questão, considerava puníveis aqueles que infamassem a totalidade ou a maioria absoluta dos membros da assembléia geral legislativa, ou de cada uma das duas.

Quanto à terceira pergunta, afirmava que não se poderia estender as injúrias ao governo ao imperador, que era constitucionalmente inviolável e sagrado. E, para a última questão, inocentava todos aqueles que publicassem os discursos parlamentares ${ }^{46}$.

No dia 27 de junho de 1827, o parecer entra em discussão no plenário. Bernardo Pereira de Vasconcelos é o primeiro a falar, colocando-se contra o documento, que segundo ele criava direito novo ao igualar cada uma das câmaras de representantes à sua

\footnotetext{
${ }^{46}$ ACD, sessão de 23/6/1827.
} 
reunião, a Assembléia Geral. Na prática, o deputado mineiro combatia a extensão da pena de degredo de três anos aos que fossem considerados detratores de qualquer uma das casas legislativas. Defende ainda que não fossem atribuídas as mesmas penas aos escritores que injuriassem cada um de seus membros, individualmente, e àqueles que atacassem uma das câmaras. Isso porque

"no caso de ser atacada a maioria ou totalidade dos membros de cada câmara por algum escritor, não deva ser punido porque é muito útil que as nossas opiniões sejam severamente examinadas, visto que por elas não temos responsabilidade. A minha opinião é mais favorável aos escritores; para que fazer caso de imputações falsas de um escritor? Se elas são verdadeiras, para que puni-las? (...) Eu desejo pois a maior liberdade aos escritores nesta matéria; escrevam o que entenderem; se caluniarem, a opinião pública os condenará e se não caluniarem cumpre que sejam ouvidos em utilidade pública. Voto pois contra este $1^{\circ}$ artigo da resolução, tanto por conter direito novo em sua primeira disposição, como por ser pouco liberal em sua segunda parte" ${ }^{\natural 7}$.

O mineiro Lúcio Soares Teixeira de Gouvêa faz questão de colocar-se do lado de Vasconcelos no que diz respeito à liberdade dos escritores, mas deixa claro que a legitimidade da informação se perde quando se trata de injúrias. Defende o parecer da comissão, dizendo que, caso se adote a interpretação de Vasconcelos, nunca um escritor seria condenado por atacar a assembléia geral, uma vez que poderia, ao invés disso, insultar cada uma das câmaras em separado e assim livrar-se da acusação. Existia uma grande preocupação em dotar a lei de mecanismos hermenêuticos que garantissem a condenação dos jornalistas incriminados, compreensível na medida em que se considera que a verificação destes crimes poderia tornar-se tarefa extremamente subjetiva e suscetível de grandes malabarismos interpretativos da defesa.

Lino Coutinho também rechaça a interpretação de Vasconcelos, deixando claro não questionar o direito inalienável à expressão dos pensamentos:

"Torno a dizer, ninguém até aqui avançou que não devia ser permitido a qualquer escritor censurar as falas dos srs. Deputados, fazerem discursos sobre elas, mostrarem sua bondade ou maldade, e finalmente sua falta de princípios e

\footnotetext{
${ }^{47}$ ACD, 27/6/1827, p. 165.
} 
lógica; mas fiquem sabendo os escritores também que não podem atacar, injuriar e dizer impropérios" ${ }^{\prime 4}$.

Ainda que não se contrarie o direito da imprensa, a vaguidão com que são caracterizados os abusos ("ataques", “injúrias" e "impropérios" se prestam ao malabarismo interpretativo tanto quanto a falta de rigor nas direções impostas pela lei) torna difícil uma delineação clara do que pode ou não ser publicado.

José Cesário de Miranda Ribeiro, outro deputado de Minas, esclarece a função política da lei, que deve ser observada quando de sua interpretação:

"sendo o fim da lei manter ilesa a forma de governo adotada, defendendo-a de todos os ataques que pudessem de qualquer modo influir para o seu aniquilamento, e sendo certo que, destruída uma das câmaras, está destruída a assembléia geral, e consequentemente a forma de governo adotada, temos pelo mesmo fim da lei evidentemente demonstrada a primeira conclusão [do parecer da Comissão]"49.

Assim, a interpretação mais restritiva se presta a garantir que não se ameaçasse a existência ou credibilidade da Assembléia ou câmaras legislativas. Mais uma vez, depara-se com a idéia de que os ataques às instituições não devem ser tolerados por serem especialmente nocivos à sua permanência.

Almeida e Albuquerque, em seguida, faz um longo discurso sobre a inviolabilidade da opinião dos parlamentares, deduzindo daí o crime de injúria ou de ataque a elas que podem eventualmente cometer os escritores. Mas apega-se à parte formal do argumento de Vasconcelos, e concorda que a resolução da comissão não pode passar porque criaria um direito novo, e para tanto seria necessário um projeto de lei.

Vasconcelos discursa novamente, dessa vez descrevendo a relação de forças que julgava operar entre governo e jornalistas:

"Compare-se um escritor e um empregado. De uma parte aparece um homem que muitas vezes terá boas intenções e nada mais, e da outra um poderoso a que se facilitarão todos os meios de acabrunhar e oprimir o escritor: colegas, amigos, validos e dependentes, tudo favorecerá ao empregado. E não havendo atenção a

\footnotetext{
${ }^{48}$ Idem, p. 166.
}

${ }^{49}$ Idem, p. 167. 
isto para a minoração das penas, poderá haver liberdade de imprensa? Entendo que só para ninharias"

O deputado pinta a categoria jornalística como um ente moderno contraposto às forças patrimonialistas a favor dos empregados públicos. Além disso, parece esquecer por um momento das conexões e interesses políticos que moviam muitos dos periodistas, e lhes credita apenas "boas intenções".

Ao final da discussão dos primeiros dois pontos, ninguém havia defendido a interpretação de Vasconcelos, e mesmo o artigo sendo emendado, sai com a compreensão de que o ataque a uma das câmaras configurava ataque à assembléia nacional.

O parlamentar mineiro também inicia o debate sobre o $3^{\circ}$ ponto, que perguntava se as ofensas dirigidas aos agentes do poder executivo podiam ser indiretamente dirigidas ao chefe deste poder, negando veementemente esta interpretação. Lino Coutinho parece ofender-se com a pergunta do promotor, pois ela toca na questão da inviolabilidade do imperador:

"Como é que se pode perguntar uma coisa que se acha na constituição, uma coisa que não admite interpretação alguma? Por ventura será permitido perguntar se todos os homens nascidos no Brasil são cidadãos? Que havia esta câmara de responder se uma autoridade pública fizesse esta pergunta? Havia de dizer: leia a Constituição, isto é claríssimo. E como pode o promotor duvidar que a pessoa de S. M. é inviolável e que é sagrada, que não tem ponto de contato a respeito da responsabilidade com outro empregado? (...) Eu não creio que o promotor a fizesse por ignorância, porque antes me dizem ser um ministro de luzes e probidade, mas talvez cedesse ao tempo, porque tem-se visto aparecer periódicos que querem identificar os ministros com o imperador, ${ }^{, 51}, 52$.

A questão é rapidamente discutida, com todos os oradores lembrando dos artigos da constituição que afirmam ser o imperador agente inviolável.

Chegada a discussão da última pergunta, Vasconcelos, mais uma vez, se levanta para afirmar que tal interpretação somente serviria para embargar a circulação dos

\footnotetext{
${ }^{50}$ Idem, p. 168.

${ }^{51}$ Idem, p. 171.

52 Para o argumento deste texto, não seria necessário inserir os dois primeiros períodos da fala de Coutinho; considerei, porém, que o exemplo de questão descabida utilizado pelo orador era interessante em si, por revelar a obviedade da desigualdade cívica nos primórdios do Império brasileiro.
} 
discursos parlamentares, impedindo sua devida publicização. Lino Coutinho também é contra, lembrando que a câmara legislava para o público e, assim sendo, não caberia responsabilizar ninguém pelo que ali se dissesse. Além disso, a questão da inviolabilidade das opiniões dos deputados, nesse caso, deveria ser estendida aos jornalistas:

“ora, Sr. Presidente, se nós somos invioláveis e podemos dizer (não aquilo que nos vier à cabeça) o que for de razão, que culpa pode ter o publicista ou editor que for escrever ou dar ao público as nossas opiniões? Este homem não pode ter criminalidade nenhuma porque não faz mais do que contar uma coisa que todo o mundo poderia ouvir se pudesse vir aqui”, ${ }^{, 53}$.

E a resposta vai nesse sentido, após essa brevíssima discussão.

Assim, em 13 de setembro de 1827, o governo publicava as instruções sobre a interpretação da lei: esclarecia que o artigo $8^{\circ}$ do decreto de 22 de novembro de 1823 referia-se ao abuso de difamar ou injuriar cada uma das Câmaras ou a totalidade ou maioria absoluta de seus membros. Dizia também que a infâmia ou injúria feita a um integrante do poder executivo, ou a todos, não poderia, pela interpretação dos jurados, ser estendida ao Chefe do mesmo poder e, finalmente, que aqueles que publicassem opiniões expressas por deputados e senadores no exercício de suas funções não podiam ser responsabilizados pelas mesmas ${ }^{54}$.

Ainda antes da aprovação definitiva da lei, em 12 de setembro de 1828, um decreto legislativo estabeleceu o processo que deveriam seguir as sessões dos jurados para os casos de abuso da liberdade de imprensa. Esses conselhos deveriam reunir-se, na Corte, a cada dois meses, nas capitais de províncias a cada quatro, e nos demais lugares sempre que necessário, mas nunca com intervalo menor do que seis meses. Nas ocasiões em que não houvessem escritores pronunciados pelos promotores fiscais, os jurados não se reuniriam, e as sessões deveriam durar o tempo preciso para apreciar todos os casos.

A Fala do Trono que abriu a sessão legislativa de 1829 revelou a preocupação e o incômodo vivenciados pelo imperador com a atuação dos jornalistas da oposição:

"O abuso da liberdade da imprensa, que infelizmente se tem propagado com notório escândalo por todo o império, reclama a mais séria atenção da

\footnotetext{
${ }^{53}$ Idem.

${ }^{54}$ Coleção das Leis do Império, 13/9/1827.
} 
assembléia; é urgente reprimir um mal que não pode deixar em breve de trazer após de si resultados fatais"

No ano em que se acirrou muito a oposição da Câmara ao governo, a resposta a tal questionamento apenas dizia que a lei específica já estava em tramitação.

No Senado, o debate sobre a lei de imprensa mostra-se sintonizado com o da Câmara. Por exemplo, repete-se fielmente a noção da essencialidade da liberdade de imprensa para o regime representativo, como exemplifica o discurso do Marquês de Queluz, João Severiano Maciel da Costa:

“A liberdade da imprensa é o sustentáculo dos governos constitucionais, é o veículo da felicidade de toda a sociedade, porque daqui é que vem as luzes a todo o Império; o contrário é ir pôr aos homens uma mordaça para não falarem" 56 .

Além da importância para o governo constitucional, aqui também se salienta a função educadora da imprensa, que cada vez mais se revela uma peça chave para a compreensão dessa legislação.

Muitos outros temas são abordados de forma semelhante à discussão da câmara: a penalidade que deveriam sofrer as gravuras, a tentativa de suprimir o adjetivo 'diretos' no trecho relativo aos ataques ao governo e à religião, a proteção à vida privada do cidadão, a possibilidade de denúncia de crimes de funcionários públicos; por não apresentarem nenhuma novidade em relação ao que já foi dito, não serão aqui expostos em detalhe.

A coincidência que vale a pena ser ressaltada e examinada é aquela que aponta para a conjunção entre governo representativo, liberdade de imprensa e segurança do Estado (expressão que aparece pela primeira vez nos debates, indício de quão poderosa a imprensa se apresentava aos senadores). Estes termos aparecem em um discurso do Marquês de Caravelas:

“(...) a lei trata sobre um objeto de muita dificuldade, porque nós queremos por uma parte sustentar o paládio da liberdade de imprensa, e por outra parte atender à segurança do Estado. Se eu visse que as luzes estavam muito derramadas no país eu estaria pelos princípios todos, que emitiu o nobre senador, princípios, aliás, verdadeiros; mas falta-nos a instrução, porque eu estou persuadido que a instrução geral é a melhor e maior garantia do governo;

\footnotetext{
${ }_{55}^{5}$ ACD, 3/5/1829, página 7.

${ }^{56}$ Anais do Senado (daqui em diante, AS), sessão de 9 de maio de 1829, página 92.
} 
porque ela estabelece uma base à segurança, e obrigações do cidadão (...). A instrução geral é a alma de todos os governos bem constituídos, ao mesmo tempo faz amar os bens que conhece, e em todo sentido o governo é o seu maior bem; é igualmente o maior inimigo do sedicioso, desse homem botafogo (...). Se isto fosse onde já estivessem as luzes espalhadas, teria todo o lugar; mas em um país onde agora isto apenas principia a nascer, como é que queremos ir nós com tanta largueza? (...) o perigo está em folhas avulsas e periódicos; estas vão ensinando, e quando se apresenta já o sintoma é tarde para remediar (...). Virá o tempo em que possa dar-se essa amplidão; talvez que não seja nos nossos dias, mas será para os que vierem depois; nós não queremos pôr peias, mas não queremos uma total liberdade" ${ }^{, 57}, 58$.

Novamente, vê-se enunciada a idéia de que um povo instruído não sucumbiria ao discurso demagógico ou revolucionário de agitadores sociais. A política, então, é colocada como uma questão de luzes, de esclarecimento, e na medida em que estes se forem vulgarizando, maiores parcelas da população poderiam ser incluídas nos formalismos da participação política e também se poderiam alargar as possibilidades de atuação dos jornalistas.

O senador combatido por Caravelas no início do discurso é Maciel da Costa, que defendeu anteriormente a liberdade de analisar o sistema de governo, falar de suas falhas e propor melhoramentos:

"Isto não é opor-me à lei, mas eu quereria que ela se restringisse a punir nomeada e unicamente os impressos incendiários, que provoquem os cidadãos a derribar o sistema monárquico constitucional representativo que adotamos, sem ir punir o escritor filósofo, que dissertar sobre este ou aquele ponto do nosso sistema" 59 .

A essa proposta de Queluz replica Carneiro de Campos:

"Qualquer escritor pode fazer observações, sim; mas, como ainda são melindrosas as nossas circunstâncias, acredito que não se deve permitir tanto, quanto quer o nobre senador. Acho que muito convém reprimir os que atacam

\footnotetext{
${ }^{57}$ AS, idem, páginas 92-93.

${ }^{58}$ Mais a frente, o senador dá um exemplo significativo do que considera ser o poder da instrução: "o homem rústico, quando se lhe puser um tributo que seja pesado, que dirá? Quando, porém, o povo for instruído, abraça-o, ainda que lhe custe; sofre este tributo porque vê a necessidade da Nação; assim, as luzes são o primeiro sustentáculo da liberdade de imprensa (...)" (AS, 9 de maio de 1829, página 95).

${ }^{59}$ AS, sessão de 8 de maio de 1829 , página 84
} 
o nosso sistema atual, por isso que queremos que ele continue a existir, como a única forma de governo que pode fazer a prosperidade do Brasil" 60.

Como na Câmara dos Deputados, o Senado discute o potencial subversivo da imprensa sem considerar o analfabetismo e relaciona-o intimamente com possíveis rebeliões contra o governo, ou catástrofes políticas ainda maiores; dessa forma, toda a legislação contra o abuso da liberdade mostra-se marcada pelo medo de ver derrubadas as instituições representativas que se erguiam, e isso valia tanto para os absolutistas interessados em retornar ao Antigo Regime quanto para aqueles que reivindicavam bases políticas mais democráticas. Essa preocupação, expressa de maneira tão enfática e praticamente unânime, sugere que a imprensa constituía-se como meio efetivo de mobilização e agitação política à época, inclusive das camadas sociais mais baixas.

Em 1830, o imperador, na fala do trono, novamente lembra da necessidade do estabelecimento de medidas contra os abusos da imprensa:

"Vigilante e empenhado em manter a boa ordem, é do mais rigoroso dever lembrar-vos a necessidade de reprimir por meios legais o abuso que continua a fazer-se da liberdade de imprensa em todo o Império. Semelhante abuso ameaça grandes males; à assembléia cumpre evitá-los"61.

A insistência de D. Pedro neste assunto revela o incômodo causado no governo pela amplitude cada vez maior conseguida pelas opiniões oposicionistas, no parlamento e na imprensa. A discussão dos deputados deste ponto da sua fala trouxe à tona novas reclamações contra o patrocínio do governo a periódicos que atacavam a Câmara, como a falecida Gazeta do Brasil e o Analysta. Esses jornais ainda contariam com o privilégio de nunca serem levados aos jurados (ou, quando isso acontecia, conseguiam ser absolvidos), e esse era o principal problema do abuso da imprensa, a aplicação ineficaz da lei.

O projeto da lei retorna à Câmara dos Deputados neste ano, com algumas emendas. Todas foram aceitas, apesar de alguma resistência de alguns parlamentares, como Vasconcelos, em nome da aprovação rápida de tão necessária lei. O texto final evidencia a preocupação em proteger o sistema político e seus símbolos de ataques renhidos, aqueles considerados ameaça ao sistema político e à ordem pública. Os crimes previstos são elencados de tal maneira que permitem entrever a relevância que têm na percepção dos legisladores: em primeiro lugar, como crimes máximos e com maiores

\footnotetext{
${ }^{60}$ AS, idem, página 87.

${ }^{61} \mathrm{ACD}, 3 / 5 / 1830$, página 63.
} 
penas, vêm "os ataques dirigidos a destruir o sistema monárquico representativo, abraçado e jurado pela nação e seu chefe", "as provocações dirigidas a incitar rebelião contra a pessoa do imperador e seus direitos ao trono", e as "imputações ofensivas e injúrias expressas ou por alegorias ao Imperador", todos punidos com prisão de três a nove anos e pagamento de multa de um a três contos de réis. Em seguida, aparecem o incitamento à desobediência das leis, a zombaria contra a religião do Império e a propagação de doutrinas dirigidas a destruir as verdades da existência de Deus e da imortalidade da alma, punidos com prisão de dois a seis anos e pagamento de multa de 800 mil réis a $2 \$ 400$ mil réis.

Também se previnem contra as ofensas ou injúrias feitas à Imperatriz, ao príncipe herdeiro, ao regente, à Assembléia Geral e às câmaras em particular, com prisão de um a três anos e multa de 300 a 900 mil réis. Os membros das câmaras ou da família real são protegidos em outros artigos, que prevêem penas de prisão de seis a dezoito meses. Por fim, os crimes ditos públicos ainda compreendem a ofensa evidente da moral pública, punida com prisão de seis meses a um ano e pagamento de 50 a 150 mil réis.

Contra entes privados, fossem corporações ou indivíduos (especialmente funcionários públicos), os delitos previstos eram as injúrias contendo imputações de crimes públicos ou infrações de leis no exercício de suas atividades. A grande diferença em relação aos ataques feitos aos entes públicos é que aqui os acusadores deveriam apresentar provas em favor de suas denúncias; caso contrário, poderiam cumprir penas de prisão que iam de um a dezoito meses (dependendo do tipo de acusação e se ela era destinada a uma corporação ou a funcionário público, sendo considerada mais grave a segunda) e multa de 30 a 120 mil réis. E, por fim, as injúrias e calúnias referentes à vida privada de qualquer cidadão, independente de prova, seriam punidas com um a três meses de detenção e pagamento de 20 a 200 mil réis, dispositivo que garantia a inviolabilidade da casa e da vida íntima.

Não é comum que as leis apontem em seu texto os casos que não configuram crime, mas esse é um expediente aqui utilizado devido à importância da liberdade de imprensa para o sistema representativo: era consenso que para a existência de representação política era fundamental a circulação de idéias e debates sobre o andamento das coisas públicas e, por isso, acreditou-se apropriado incluir um parágrafo que dirimisse as dúvidas a respeito da legalidade de certas opiniões publicadas. Assim, o artigo $3^{\circ}$ tratava de estabelecer os casos em que não cabia a abertura de processo 
criminal por abuso da liberdade de imprensa: as análises razoáveis dos princípios e usos religiosos, da constituição e das leis existentes ${ }^{62}$, as censuras aos atos do governo e à administração pública (desde que não fosse questionada sua autoridade legal), e demais considerações que, ainda que vigorosas, fossem apresentadas em termos "decentes e comedidos".

Há de se considerar aqui a dificuldade de distinguir com precisão o que seriam investidas contra o regime das análises razoáveis legítimas previstas pela lei. A resolução desta ambigüidade dependia da orientação do encarregado por sua interpretação: a mesma frase poderia ser considerada abuso pelo Procurador responsável pela pronunciação do impresso, normalmente agente do governo, e inocentada pelo júri popular, o que de fato ocorreu inúmeras vezes durante todo o Império. Inclusive, podese conjecturar que justamente por causa disso alguns parlamentares liberais moderados não se opuseram tão fortemente aos preceitos conservadores da lei quando ela foi discutida.

De todo modo, é importante frisar que mesmo o poder legislativo, mais liberal do que o executivo quando se tratava da liberdade de imprensa, criava regras duras para a atividade jornalística, sem dúvida limitando a amplitude do debate político.

Outra instituição importante consagrada pela lei de liberdade de imprensa é o julgamento dos delitos de opinião pelos jurados. Foi reafirmado o seu caráter eletivo e temporário, e assegurada a exclusividade de sua competência: os crimes de imprensa não poderiam ser julgados por quaisquer outras instâncias, e de seu veredicto só se apelaria ao Imperador. Se, por um lado, isso dificultava aos condenados a revisão de sua sentença, por outro garantia a soberania do júri, que não teria suas sentenças contrariadas pela magistratura togada. Tal característica visava a garantir que o julgamento dos crimes de imprensa, políticos por natureza, não dependesse de agentes ligados ao governo, mantendo o caráter popular da decisão. Se tomarmos em consideração a evidência de que a tendência do júri era a de absolver os acusados por abuso, a conclusão é de que tal independência era favorável aos jornalistas, jogando assim a favor da manutenção da liberdade de imprensa.

Por fim, cabe uma palavra a respeito da responsabilização estabelecida na lei. A princípio, quem deveria responder por qualquer documento era seu impressor, que poderia isentar-se dela apresentando um termo de obrigação assinado pelo editor, desde

\footnotetext{
62 “não se atacando suas bases fundamentais, e sem provocar desobediência a elas". (Lei de 20 de setembro de 1830, Coleção das Leis do Império).
} 
que esse fosse pessoa conhecida, residente no Brasil, e, ainda, em pleno gozo de seus direitos políticos. O editor poderia, por sua vez, passar a responsabilidade para o autor mediante comprovação semelhante. A preocupação era evitar que os envolvidos na cadeia produtiva da imprensa se utilizassem de substitutos legais para tornar públicas suas 'subversões' políticas sem serem incriminados, e deixa claro que, definitivamente, não se pretendia abrir a todos o espaço público de discussão, mas sim aos cidadãos que, nessa qualidade, tivessem algum comprometimento (indicado pela posse da quantia necessária para participar das eleições ${ }^{63}$ ) com a ordem estabelecida. Mas, como se verá mais à frente, essas exigências não foram suficientes para evitar que terceiros assumissem a responsabilidade por determinados impressos.

Uma semana antes da promulgação do Código Criminal, que englobaria as disposições legais sobre os crimes de abuso da liberdade de imprensa, publica-se uma decisão do ministério da Justiça reveladora de que, apesar da existência da lei e dos esforços do governo para conter os abusos dos escritores, os periódicos continuavam a desafiar os limites impostos:

"Tendo aparecido nos jornais publicados nesta cidade notáveis abusos do direito que a Constituição garante a cada cidadão de poder comunicar os seus pensamentos pela imprensa, sem que o Promotor do Júri, até o presente tenha chamado ao Júri, como cumpria, em desempenho dos deveres do lugar para que fora eleito, os responsáveis que, animados pela impunidade nascida da sua omissão, tem avançado ao excesso de já atacarem os princípios fundamentais da constituição, emitindo doutrinas subversivas das bases do sistema jurado, provocando a anarquia e excitando a rebelião contra a sagrada pessoa de S. M. o Imperador e seus direitos ao Trono: manda o mesmo Augusto Senhor que V. S. represente ao Promotor do Júri a necessidade de tais acusações, e, no caso dele se recusar, proceda a requerer contra ele na conformidade do art. 51 da Lei de 20 de Setembro do corrente ano"

O problema, aqui, parecia ser a inação do Promotor do Júri, encarregado de dar início aos processos. Mais uma evidência do provável apoio que os magistrados eleitos garantiriam aos jornalistas - mais do que absolvê-los, evitavam inclusive pronunciá-los. Outra explicação razoável é a de que os funcionários de cargos eletivos realmente

\footnotetext{
${ }^{63} \mathrm{O}$ texto da lei fala somente de 'direitos políticos', e por isso não é possível saber se se referia à franquia necessária para ser votante ou eleitor.

${ }^{64}$ Coleção das Leis do Império. Decisão do ministério da Justiça, 11 de dezembro de 1830.
} 
afinavam-se com tendências políticas liberais, contrárias aos rumos que o governo de D. Pedro ia tomando, e dessa forma tendiam a considerar legítimas, e não abusivas, as manifestações de reproche ao monarca e seu ministério.

Como foi dito, o Código Criminal, promulgado em 16 de dezembro de 1830, englobou a competência da lei de 20 de setembro. As penas dos crimes políticos ou públicos $^{65}$ foram atenuadas (a maior pena de detenção, que era de três a nove anos, passou a ser de um a quatro), e os crimes contra particulares receberam penas mais severas (injúrias e calúnias contra corporações e funcionários públicos, por exemplo, tinham pela lei anterior pena de prisão de seis a dezoito meses, enquanto o Código previa oito meses a dois anos) ${ }^{66}$. Foram acrescidas determinações de controle da atividade tipográfica nos municípios: os impressores deveriam dar parte da abertura de novos estabelecimentos à Câmara Municipal e sempre manter atualizado o seu endereço, sob pena de multa de 12 a 60 mil réis, além de declarar em todo o material que produzissem o seu nome, a localização da tipografia, o ano em que a obra foi produzida e o que foi impressa. A ausência de qualquer dessas informações implicava na perda dos exemplares defeituosos e pagamento de multa entre 25 a 100 mil réis; o uso de informações falsas dobrava o valor da multa e, caso se utilizasse nomes de pessoas ainda vivas o valor era novamente dobrado. Finalmente, era crime deixar de enviar um exemplar de cada impresso, no dia de sua publicação ou distribuição, ao promotor municipal - a pena era multa de dez a 30 mil réis.

Apesar dessas mudanças, a maioria dos artigos referentes aos crimes de abuso de liberdade de imprensa foi copiada sem nenhuma alteração da lei de 20 de setembro. É o caso da hierarquia de responsabilidades (impressor, editor, autor, vendedor) e dos ataques previstos contra o sistema de governo, a constituição, os cultos ou a moral pública, assim como do artigo que esclarece os casos nos quais não há abuso. Outro sinal de que não houve grande novidade a esse respeito é a ausência de apreciação do tema quando da discussão do código na Câmara dos Deputados.

\footnotetext{
65 Separados em diferentes seções: "crimes contra a existência do Império", "crimes contra o livre exercício dos direitos políticos", "crimes contra a segurança interna do Império e a pública tranqüilidade" e "crimes policiais".

${ }^{66}$ Barbosa Lima Sobrinho faz a esse respeito um comentário curioso: "Não sabemos porque, elaborado num regime de exaltação, o Código de 1830 atenuou a lei de 20 de setembro daquele mesmo ano. Acreditamos haver um motivo particular, que desconhecemos." (Barbosa Lima Sobrinho, op. cit.). A essa questão pode-se oferecer uma hipótese: o elaborador do texto Código Criminal foi Bernardo Pereira de Vasconcelos, opositor ferrenho do projeto sobre os abusos de liberdade da imprensa quando este passou pela Câmara.
} 
Vale a pena examinar as opiniões de comentaristas coevos do Código Criminal. Apesar das análises encontradas terem sido produzidas em período que ultrapassa o delimitado nesta pesquisa, elas expressam uma espécie de visão consolidada sobre a experiência da aplicação das suas disposições que agrega elementos importantes à compreensão do sistema que se instaurou.

Manoel Mendes da Cunha Azevedo, juiz de carreira, combate duramente o que chama de 'partidários da imprensa licenciosa' e a interpretação que estes tentam impor dos artigos referentes ao abuso da imprensa ${ }^{67}$. Em primeiro lugar, revela que a determinação do responsável pela tipografia - o primeiro a responder pelo eventual abuso de uma publicação - não era tarefa fácil para os promotores e jurados: devido às manobras hermenêuticas dos libelistas, havia a possibilidade de se indicar apenas o gerente ou administrador, livrando o proprietário da acusação. Mais ainda, como a lei não determinava nenhuma habilitação específica para aquele cargo, apontava-se qualquer um como sendo o gerente que autorizou a produção de trabalho abusivo: "o vadio, o vagabundo, o mendigo, o proletário, o criminoso, e até o escravo" ${ }^{\text {„68 }}$. Assim se garantiria a impunidade dos verdadeiros incendiários, capazes de subornar indivíduos socialmente rebaixados para que assumissem sua culpa e, permanecendo livres, continuarem suas publicações criminosas ${ }^{69}$.

Outra questão atacada por Azevedo dizia respeito aos requisitos para que o impressor provasse que era o editor o responsável pela publicação e, correlatamente, o editor fizesse o mesmo em relação ao autor. A lei exigia que aquele que se responsabilizava pelo impresso deveria ser pessoa conhecida, residente no Brasil e estar no gozo de seus direitos políticos. A imprecisão do artigo permitia que todas fossem burladas:

“o impressor nenhum obstáculo encontra no sistema repressivo da legislação para aceitar a responsabilidade de qualquer bandalho ou vadio que por paga, ou outro motivo semelhante, subscreva a obrigação do escrito. Isto não é uma hipótese gratuita, mas desgraçadamente uma realidade de todos os dias. Quantos, mesmo na classe dos homens mais pobres, e de mais obscura condição, deixam de ser conhecidos e de ter direitos políticos no Brasil? Podemos sem exagero

\footnotetext{
${ }^{67}$ Manoel Mendes da Cunha Azevedo. O Código penal do Império do Brasil com observações sobre alguns de seus artigos. Recife: Tipografia Commercial de Meira Henriques, 1851

${ }^{68}$ Idem, página 59.

${ }^{69}$ Não que fosse impossível, para um redator, continuar a publicação de seus jornais da prisão, como atestam os casos de Borges da Fonseca e Cipriano Barata - mesmo encarcerados, não deixaram de escrever e distribuir seus periódicos. Cf. Marcello Basile e Nelson Werneck Sodré, op. cit.
} 
afirmar que, exceto os escravos, todos têm as habilitações precisas para a responsabilidade legal. $\mathrm{O}$ fato das eleições primárias bastaria para responder a qualquer resultado do mais profundo exame a este respeito" ${ }^{\text {"70 }}$.

Além disso, no que diz respeito à residência no país, o impressor sempre tinha a possibilidade de indicar um editor que vivesse no exterior (pois não era necessário comprová-lo), eximindo-se da culpa e impossibilitando a continuidade do processo.

Desse modo, a conclusão do autor é que a "falange de libelistas" formada para combater pelos recursos do prelo as "virtudes e princípios que se opõem aos interesses da anarquia e da depravação dos costumes", levava adiante o "tenebroso plano da desmoralização pública" por meio da inteligência por eles atribuída aos artigos $7^{\circ}$ (da hierarquia das responsabilidades) e $303^{\circ}$ (da qualificação do impressor), tirando

"ao dono da tipografia a dificuldade de consentir na impressão de toda a sorte de libelos e convícios, mandando escrever nos livros da Câmara e em todos os escritos impressos o nome de qualquer proletário ou vadio assalariado para responder pelos abusos na qualidade de impressor à falta de editor com as qualificações legais. (...)"

Outro comentarista do Código é o Conselheiro J. Liberato Barroso ${ }^{72}$, que se mostra mais alarmado com a situação da atividade jornalística do que seu colega Azevedo:

“confrange-se de dor o coração, e o espírito sucumbe às mais sinistras apreensões ao contemplar o estado a que entre nós reduziram os miseráveis esse maravilhoso instrumento da civilização. A calúnia e a difamação pela imprensa é uma especulação, com que alguns miseráveis têm conseguido os seus fins. Vende-se uma descompostura a troco de dinheiro, de um emprego, de uma posição social, e não se sabe o que mais se deve admirar, se o cinismo e a audácia com que negociam os difamadores, se a infâmia dos que compram seus serviços"

Nesse parágrafo, encontra-se uma censura aos jornalistas que vendiam o espaço de seus jornais para publicar injúrias a respeito dos pretendentes dos cargos públicos e aos que se utilizavam desse serviço. O conselheiro é outro dos que defendem a função civilizadora da imprensa, apóstola da consciência e da verdade - palavras que não

\footnotetext{
${ }^{70}$ Idem, página 71 .

${ }^{71}$ Idem, páginas 88 a 90.

${ }^{72}$ J. Liberato Barroso. Questões práticas de Direito Criminal. Rio de Janeiro: B. L. Garnier, 1866.

${ }^{73}$ Idem, página 55.
} 
dizem muito, é verdade, mas revelam inclinação iluminista, crença no exercício da pedagogia dos direitos e deveres do povo a ser guiado pelos 'bons' princípios da manutenção da organização da sociedade - em detrimento "do crime e da subversão social". Nesse sentido, adota as posições de Azevedo e faz duras críticas à condenação de testas-de-ferro usados pelos verdadeiros criminosos, que classifica como distorção completa da lei.

Por fim, é interessante falar a respeito da única voz dissonante a respeito da censura prévia encontrada em todos os documentos analisados ${ }^{74}$. Braz Florentino Henriques de Souza, lente de direito civil na Faculdade de Direito do Recife, defende a censura prévia como o meio mais eficaz para garantir a ordem do Estado e as instituições legislativas sobre as quais se mantém. A repressão judiciária, outro mecanismo social para a contenção dos abusos da expressão do pensamento, seria mais coerente com a expansão dos direitos individuais que então se verificava. Souza encara como "gostos e caprichos um tanto inexplicáveis" a recusa terminante à aplicação de censura prévia aos impressos e a concomitante exaltação da imprensa como "a mais poderosa das alavancas da sociedade" e "o quarto poder do Estado"75 - tamanho poderio não poderia simplesmente ser exercido por indivíduos que podem não ter nenhum comprometimento com a existência e os interesses nacionais. Como não podia deixar de ser, é mais um a lamentar a impunidade que deriva do laconismo dos artigos referentes à liberdade de imprensa e da excessiva liberalidade dos legisladores originais, que na época da elaboração do Código estavam embebidos da radicalidade das lutas políticas de seu tempo.

O que se depreende dessas análises é a sensação de que poucos eram efetivamente punidos por expressarem suas opiniões nos termos prescritos pela lei. Obviamente, trata-se de testemunhos de homens conservadores, que não se habituariam a ver a ordem estabelecida tão abertamente questionada, nem a honra de seus agentes atacada.

Importa notar também que se criavam artimanhas entre os publicistas para evitar possíveis condenações, o que de alguma maneira incrementava a liberdade de expressão. Um aspecto interessante destes 'relatos', certamente, é o fato de que, a crer neles, este aumento das possibilidades de expressão pública se dava somente na medida

\footnotetext{
${ }^{74}$ Braz Florentino Henriques de Souza. Lições de Direito Criminal. Paris: V ${ }^{\text {va }}$ J. P. Aillaud Guillard E. Ca 1872. Lição $3^{\text {a: }}$ : Dos responsáveis nos crimes de liberdade de exprimir os pensamentos (originalmente publicada em 1866)

${ }^{75}$ Idem, nota de rodapé à página 169.
} 
em que existiam indivíduos dispostos a aceitar o risco de serem condenados e presos em troca de pagamento, assinando textos que não escreveram e, com isso, assumindo opiniões de outros como suas. Ou seja, "garantia-se" a extensão dessa liberdade individual por meio da desigualdade econômica e social. Um tipo curioso de exclusão: não é que os mais pobres não participassem da produção letrada dos impressos; inseriam-se de forma marginal e criminalizante, como testas-de-ferro que, uma vez pegos, eram facilmente substituíveis por outros em situação semelhante - um traço elitista a ser incorporado à imagem da esfera pública brasileira imperial.

\section{Abdicação de D. Pedro e período das regências}

A oposição parlamentar ao governo de D. Pedro se tornava cada vez mais acentuada. A partir de 1829, a situação acirrara-se de tal modo que a abdicação já seria então inevitável; a Câmara eleita em 1830 foi composta majoritariamente de liberais moderados decididos a disputar arduamente a predominância com o executivo. Um bom exemplo da disposição legislativa de dificultar que Imperador obtivesse os meios necessários para governar foi a transferência dos recursos destinados à remuneração dos contingentes militares estrangeiros da lei de forças para a de orçamento, que estava sob seu controle, garantindo que o dinheiro não chegasse ao seu fim e enfraquecendo a principal base de apoio militar de D. Pedro ${ }^{76}$.

Acontecimento importante a amplificar a crise política foi o assassinato do jornalista liberal Líbero Badaró, redator do Observador Constitucional, para o qual colaboravam os deputados Odorico Mendes e Nicolau Pereira de Campos Vergueiro. O jornal paulistano seguia a linha oposicionista da Aurora Fluminense, inclusive reproduzindo artigos seus. Após a derrubada de Carlos X, rei da França identificado com o absolutismo, estudantes paulistas fizeram grande passeata de comemoração, reprimida como crime grave. Badaró saiu publicamente em sua defesa, atacando o ouvidor da cidade, Cândido Ladislau Japiaçu. O jornalista seria assassinado dias depois, em 20 de novembro; o crime, cujo mandante teria sido o ouvidor ofendido, foi associado ao despotismo de D. Pedro I, a quem Líbero Badaró sempre se opôs. A crônica histórica, inclusive, relata que, na chegada do imperador a Barbacena, durante a

\footnotetext{
${ }^{76}$ Tobias Monteiro, op. cit, volume 2, página 183.
} 
visita à Minas Gerais no início de 1831, os sinos badalavam em sinal de pesar pela morte do jornalista, claro sinal de descontentamento da população em relação ao governo imperial.

Essa visita, inclusive, é normalmente citada pela historiografia como o termômetro da situação de D. Pedro frente aos seus súditos: sua acolhida foi morna e não conseguiu favorecer seu ministro José Antonio da Silva Maia nas eleições para deputado. Quando volta para o Rio de Janeiro, em março, a situação começa a se tornar insustentável: aos festejos organizados pelos portugueses para comemorar seu regresso, os 'nativistas' (moderados e exaltados, unidos momentaneamente contra o inimigo caramuru) responderam com vivas à constituição e a D. Pedro II, e para que começassem os conflitos abertos não demorou muito. O mês de março foi marcado por casos quase diários de desordem e assassinatos, lutas entre brasileiros e portugueses. Finalmente, isolado e sem apoio militar, D. Pedro abdica do trono em favor de seu filho.

Para Miriam Dolhnikoff, a questão de fundo desses conflitos era a disputa entre os projetos de organização do Estado já referidos, especialmente o desejo de alguns liberais de "desenhar o Estado segundo princípios federalistas mais amplos"77. Segundo a autora, o fechamento da Constituinte em 1823 e a limitação que a Constituição de 1824 impunha à atuação dos governos provinciais $^{78}$ eram fontes perenes de descontentamento das elites provinciais que, a partir de 1826, encontraram no parlamento um espaço privilegiado para opor-se publicamente a D. Pedro e ao projeto centralizador que encabeçava. Nesse sentido, sua abdicação permitiu que fosse substituído esse regime pela federação monarquista, defendida pelos liberais que entendiam ser essa uma condição primordial para a manutenção da unidade do Império, por permitir que grupos provinciais tivessem acesso a cargos políticos e administrativos; participando das decisões governamentais, fortaleceriam seus laços com o Império e disputariam institucionalmente o atendimento de suas demandas, diminuindo as chances de uma secessão. Nas suas palavras,

"a unidade estava condicionada à capacidade de acomodar elites que tinham como prioridade o atendimento de suas demandas, de modo que encontrassem

\footnotetext{
${ }_{77}^{77}$ Miriam Dolhnikoff, op. cit., página 89.

${ }^{78}$ Uma das mais importantes leis votadas em 1827 instituía os cargos de juízes de paz (a magistratura local eleita) e, com isso, garantia o controle do judiciário aos poderosos locais. Outra, de 1828, reduzia drasticamente as prerrogativas municipais em detrimento do governo provincial. Ambas tinham sua aplicação muito restringida em função das limitações que impunha a Constituição, causando grande descontentamento entre os liberais, ciosos defensores da autonomia provincial.
} 
espaço para negociar recursos e políticas que atendessem a seus interesses específicos"79.

Dessa forma, a autora demonstra que a defesa da unidade da nação era projeto que antagonizava com a possibilidade de reformas sociais profundas (como as pretendidas por José Bonifácio, defensor da centralização estatal), e que acabou mesmo inviabilizando-as por conta de seu caráter conciliatório com interesses agrárioescravocratas $^{80}$.

Quando finalmente D. Pedro abdica do trono brasileiro, os liberais, que detinham a maioria na Câmara, aproveitam-se dessa condição e aprovam uma lei de regência que consagrava o predomínio do poder legislativo sobre o executivo ${ }^{81}$, e iniciam a campanha política que desembocará nas reformas da década de 1830, implementando o projeto de Estado que conciliava unidade com autonomia provincial.

É importante ressaltar que o termo liberal era utilizado por dois grupos monarquistas, mas distintos e heterogêneos; um defendia o federalismo monárquico e propunha as reformas descentralizadoras, enquanto o outro recusava quaisquer alterações na Constituição e, assim, identificava-se com a manutenção do regime centralizado. Havia ainda outras duas correntes políticas de menor importância: os republicanos, também partidários das reformas federalistas, mas que as consideravam possíveis apenas com a queda da monarquia, e os restauradores, advogados da volta de D. Pedro I ao trono brasileiro.

Marcello Basile, em seu trabalho sobre as identidades políticas ativas na Corte durante a Regência, afirma que o período possibilitou uma ampla disputa entre projetos nacionais na nascente esfera pública brasileira (no caso, fluminense). $\mathrm{O}$ autor divide as facções políticas da Corte, assim como os periódicos que cada uma produzia, em três correntes: liberais moderados, exaltados (republicanos) e caramurus, unindo nesta última categoria os restauradores e liberais refratários às reformas constitucionais. Ainda que politicamente estes grupos não se confundissem, faz sentido uni-los, para fins didáticos, quando o critério estabelecido para isso é a identificação com o regime centralizador instituído durante o Primeiro Reinado. De qualquer modo, o interesse deste trabalho na exposição de Basile está na exposição que faz da perseguição infligida aos periódicos exaltados e caramurus, opositores do governo dos liberais moderados.

\footnotetext{
${ }^{79}$ Miriam Dolhnikoff, op. cit., página 25

${ }^{80}$ Idem, páginas 18-19.

${ }^{81}$ Idem, página 89.
} 
Assim, a grande divergência do grupo exaltado com o moderado era sua defesa do regime republicano de governo, e por isso era necessário que encontrasse subterfúgios para expor publicamente seus projetos, pois a lei de liberdade de imprensa proibia ataques ao sistema jurado e à pessoa do Imperador. Os expedientes utilizados seriam, entre outros,

“a transcrição de artigos de outros periódicos favoráveis à república, como forma de escapar à responsabilidade penal por seu conteúdo; a citação de autores estrangeiros identificados àquele regime, enquanto argumento de autoridade; a crítica aos princípios monárquicos (vitaliciedade, hereditariedade, legitimidade, prestígio e privilégios aristocráticos); a incompatibilidade entre América e monarquia, paralelamente à afirmação de uma identidade americana ou de um ideal de americanidade (...); e a visão teleológica da monarquia como estágio primitivo em uma escala de progresso onde a república necessariamente seria o ápice. Assim, enquanto a monarquia era associada ao Absolutismo, à Europa e ao arcaico, a república identificar-se-ia à democracia, à América e ao progresso" ${ }^{\prime 82}$.

Esta corrente política teria sido responsável pela maior parte da produção de jornais na Corte entre 1829 e 1834, seguidos de perto, quantitativamente, pelos caramurus.

Estes, segundo Basile, distinguiam-se por uma defesa intransigente da Constituição de 1824, considerada "suficientemente liberal" ${ }^{\prime 83}$. Isso significava uma oposição dura a quaisquer reformas, especialmente aquelas cujo objetivo seria afrouxar a divisão de poderes estabelecida: a extinção do Poder Moderador, do Conselho do Estado e da vitaliciedade do Senado. Recusavam também a reorganização das competências do governo central e das províncias num formato federalista. Ou seja, empenhavam-se em defender a organização política posta em prática durante o I Reinado, daí sua identificação primordial com D. Pedro I. No entanto, segundo o autor, a pecha de 'restaurador' não pode ser atribuída a todos os caramurus indistintamente: era uma minoria a defender abertamente a volta de D. Pedro ao seu antigo posto; a maioria a recusava como ilegítima, e alguns propunham a solução intermediária de sua volta como regente do filho. Assim, o próprio autor reconhece que só no que tange ao

\footnotetext{
${ }^{82}$ Idem, página 203.

${ }^{83}$ Idem, página 343.
} 
determinado aspecto da defesa da centralização do poder estatal as duas facções podem ser agrupada sob o mesmo rótulo político.

Como seria de se esperar, as folhas mais processadas durante a regência foram as dos exaltados e caramurus. Os primeiros sofreram perseguição especialmente dura em fins de 1831, devido ao episódio conhecido como levante da Ilha das Cobras - uma sublevação do Corpo de Artilharia da Marinha inspirada por alguns jornais do grupo - e no início de 1832, por conta de uma mudança do júri da Corte, da qual se falará adiante. Ainda que fossem absolvidos, sofriam outros tipos de constrangimentos: Antônio Borges da Fonseca, por exemplo, quando de seu primeiro pronunciamento, em 1830, foi obrigado a abandonar o cargo de professor de primeiras letras que ocupava. Teve, no entanto, melhor sorte que Clemente José de Oliveira, redator do Brasil Aflito, assassinado pelo filho do regente Francisco de Lima e Silva, como vingança por uma suposta injúria pública à família. A repercussão do caso foi grande, mas como nenhuma testemunha de acusação compareceu ao julgamento, a acusação foi considerada improcedente e o assassino, solto.

Já a imprensa caramuru sofre grande inflexão em fins de 1833, quando diversos jornais da facção interrompem a publicação, por conta de uma ofensiva desencadeada contra o grupo motivada provavelmente pela chegada da notícia de que Antônio Carlos havia viajado à Europa para se encontrar com D. Pedro I e acertar, junto com ministros franceses e ingleses, a volta do ex-imperador.

Nelson Werneck Sodré salienta que durante o período regencial experimentou-se ampla liberdade jornalística. Otávio Tarquínio de Sousa vai mais além, afirmando que a liberdade teria sido completa. Ambos baseiam essa idéia na observada profusão de pasquins durante o período. Estas publicações, como se sabe, tinham formato menor do que os jornais, sua periodicidade era irregular e, em geral, não ultrapassavam os primeiros números. Sua linguagem era violenta e desabrida, e raramente punida pela lei, normalmente aplicada aos periódicos.

De fato, durante o período não se discutiram, no parlamento, novas medidas que contivessem a atuação política da imprensa. Ao contrário, em 7 de junho de 1831, o poder legislativo dispôs sobre exceções a serem observadas pela Administração Geral dos Correios, e uma delas dizia que os jornais nacionais destinados a bibliotecas públicas não pagariam o porte dos correios; periódicos nacionais e estrangeiros 
remetidos a particulares pagariam apenas a oitava parte da taxa ${ }^{84}$. Essa medida não deve ser desprezada, pois facilitava muito a distribuição dos periódicos pelo território nacional, possibilitava o intercâmbio de idéias e projetos entre as províncias e mesmo o estabelecimento de solidariedades e contatos políticos. Além disso, como se viu na exposição da legislação francesa, o aumento dos preços de fretes para os jornais foi um expediente usado pelos governos quando se tratava de restringir sua circulação.

Em 1833, a decisão $\mathrm{n}^{\circ}$ 793, do ministério do Império, reforçava a instrução do decreto, especificando que, para obter o desconto, os seus donos patenteassem os jornais na hora do recebimento ${ }^{85}$.

Mas, se é verdade que o poder legislativo colaborou para o crescimento da imprensa, relaxando os impostos a que estava submetida, deve ser lembrado também que o executivo tomou providências no sentido de endurecer o cumprimento da lei. São duas as mais importantes.

Em 18 de janeiro de 1832, o então ministro da Justiça Diogo Antônio Feijó baixou uma portaria que determinava a eleição de um novo conselho de jurados para a Corte, sob o pretexto de que os empossados não tinham sido escolhidos pelos eleitores do município, como mandava a lei. O júri composto após as eleições de 15 de fevereiro era muito mais afinado com o governo, e dele saíram decisões contra importantes jornais exaltados (a Matraca das Farroupilhas teve sua publicação encerrada, e seu redator foi preso; também saíram de circulação O Tribuno do Povo e a Malagueta) e caramurus ${ }^{86}$. Essa medida confirma novamente a tendência do júri a absolver os publicistas da oposição, também notada por Marcello Basile ${ }^{87}$.

Cinco anos depois, já na regência una de Feijó, o governo decreta suas "Instruções sobre o processo e sentenças nos crimes por abuso de liberdade de imprensa" ${ }^{\$ 8}$. O objetivo declarado do documento era estabelecer parâmetros a serem seguidos por todos os juízes, de modo a uniformizar a aplicação das penas e garantir a punição dos culpados, evitando que cada caso fosse julgado de acordo com a inteligência ou vontade do juiz por ele responsável. Como se viu, eram poucos os jornalistas condenados pelo júri, o que certamente inspirava um sentimento de

\footnotetext{
${ }^{84}$ Coleção das Leis do Império, 7/6/1831.

${ }^{85}$ Idem, 20/12/1833.

${ }^{86}$ Marcello Basile, op. cit, páginas 224-225.

${ }^{87}$ Idem, página 224.

${ }^{88}$ Idem, 18/3/1837.
} 
impunidade naqueles que, de alguma forma, consideravam-se atingidos pela atividade política da imprensa.

O decreto estabelecia que, para a instauração de inquérito, o denunciante deveria apresentar formalmente sua queixa, acompanhada do corpo de delito e de duas testemunhas que confirmassem a distribuição do impresso a mais de quinze pessoas. Com esse documental, o juiz mandaria vir o acusado à sua presença e então interrogaria as testemunhas. Nessa mesma etapa deveria ser proferida a sentença, e a prisão do criminoso, quando fosse o caso.

A responsabilidade pela folha, desde a lei de 1830, era primordialmente do impressor; para ser atribuída ao editor era necessário o cumprimento de uma série de exigências burocráticas que claramente dificultavam a defesa do primeiro. $\mathrm{O}$ decreto endureceu as exigências para a transferência da responsabilidade pela obra: passou a ser necessária a apresentação ao juiz, no momento da pronunciação ou da prisão, da declaração do editor responsabilizando-se pelo impresso,

"reconhecida pelo Tabelião Público, sendo ele o verdadeiro editor, pessoa reconhecida, que possa ser descoberta onde quer que seja, residente no Brasil, e que por folha corrida em todos os Juízos do seu domicílio, e atual residência, mostre estar no gozo dos direitos políticos, isto é, pelo menos em estado de votar nas Assembléias primárias" ${ } 89$.

Para que o editor, por sua vez, repassasse a culpa ao autor, era necessária uma nova rodada dessas mesmas exigências. Mas, definitivamente, o empenho era em punir os impressores: outra disposição declarava que só seria aceita a responsabilidade que tivesse data igual ou anterior à da pronunciação.

Com o decreto, buscava-se, mais do que uniformizar o processo, forçar os impressores a exigir diversos documentos daqueles que procurassem os serviços de suas tipografias e, com isso, imprimir apenas as obras de "cidadãos ativos", mais esclarecidos e menos propensos a arruaças, segundo o credo geral da época. Além disso, ser alvo primário da lei certamente influenciava as decisões a respeito de que trabalhos aceitar em seu prelo. Do lado dos editores e autores, o decreto acabou com a possibilidade de publicar trabalhos anônimos.

Em abril de 1837, outro exemplo de ação governamental contra um periódico: são expedidas duas decisões ordenando ao juiz de paz do distrito de Sacramento, da

\footnotetext{
${ }^{89}$ Decreto de 18/3/1837, Coleção das Leis do Império.
} 
província de Minas Gerais, que chamasse à responsabilidade o redator do jornal moderado $O$ Sete de Abril, que, segundo Sodré, era orientado por Bernardo Pereira de Vasconcelos ${ }^{90}, 91$.

Estas medidas demonstram que os liberais moderados, uma vez no poder, também se preocuparam em garantir meios de coibir o exercício da liberdade de imprensa, de modo a limitar a voz da oposição.

Mas o mais importante está em apontar a diferença entre as medidas adotadas por Feijó e aquelas dos tempos de Bonifácio, para a compreensão do estabelecimento da liberdade de imprensa como pressuposto inegociável do regime monárquicorepresentativo brasileiro. As providências contra a imprensa e os jornalistas de oposição tomadas por Bonifácio em 1822 inseriam-se num conjunto de medidas extraordinárias, de caráter essencialmente policial - as devassas -, e foram executadas num momento de incerteza política e jurídica (pela inexistência de Constituição). Já Feijó ampara sua repressão num instrumento legal regulamentado constitucionalmente, o decreto executivo, direcionado ao poder judiciário - ação dotada, dessa maneira, de uma legitimidade institucional muito maior. Esse "refinamento" da repressão, que então passou a se apoiar ainda mais no processo criminal, demonstra o reconhecimento de que a liberdade de imprensa (como qualquer outra liberdade civil) só poderia ser limitada se seguidos os trâmites legais para tanto. Mais ainda, indica que a repressão policial contra os jornalistas não era mais tão tolerada, o que forçou a transferência dessa atividade para o judiciário, detentor da legitimidade para julgar e condenar os casos de abuso.

Também é significativa a alteração de comportamento do governo dos liberais moderados em relação ao de d. Pedro I. A aposta não estava mais na legislação sobre a imprensa, já fartamente discutida e reformada. Tratava-se agora de reformar as instituições e, no caso do controle da imprensa, tornar eficientes, do ponto de vista governamental, as instâncias judiciárias encarregadas de punir os infratores.

Dessa forma, pode-se delinear o padrão de tratamento dispensado, pela elite política brasileira, à liberdade de expressão e seu debate durante a primeira metade do século XIX. Inicialmente, é notável a diferença das atitudes tomadas pelo poder legislativo e pelo executivo. O primeiro, espaço primordial da negociação entre as elites provinciais e de oposição legítima ao governo, exercia essas premissas de forma a regular a liberdade de imprensa, garantindo, fundamentalmente, que o seu exercício

\footnotetext{
${ }^{90}$ Nelson Werneck Sodré, op. cit, página 123.

${ }^{91}$ Coleção das Leis do Império, 4/4/1837 e 8/4/1837.
} 
obedecesse ao critério do bem-estar geral e interesse nacional, o que, nessa conjuntura, significava restringi-lo à manutenção da (específica) ordem social instaurada, regida pela cidadania restrita, marcada pela escravidão e mediada pela representação. Posições políticas que contrariassem essas características deveriam ser punidas, pois certamente obrariam contra o bom funcionamento do regime 'jurado e escolhido pela nação'. Ao mesmo tempo, havia a explícita preocupação do parlamento de assegurar à imprensa a possibilidade de engrossar a vigilância do governo, como se fosse uma extensão da tribuna, dando voz à oposição. É claro que não se trata de descrição de uma posição homogênea, defendida pelo parlamento de forma unívoca e homogênea - sempre havia entre os deputados aqueles que, pela proximidade com o governo, procuravam medidas que poupassem o executivo dos golpes impressos - mas sim de uma orientação geral, surgida da produção de leis e da resposta às dúvidas surgidas durante a sua execução. Se, por um lado, a legislação produzida no período estudado evidencia os caracteres aristocráticos e autoritários do liberalismo brasileiro (ao proibir a contestação aberta às instituições que conciliavam a monarquia com a representação política, por exemplo), por outro revela também a preocupação em garantir espaço para o debate público entre as facções que disputassem, dentro das regras do jogo, o controle dessas instituições.

Do lado do governo, a atitude era fundamentalmente diferente: tratava-se do alvo primordial das críticas e ataques vindos da imprensa e do parlamento, o que com certeza originava grandes desgastes políticos. A resposta do poder executivo à essa oposição pode ser dividida em duas vertentes: uma que privilegiava a réplica pela própria imprensa, materializada no fomento e apoio a jornais governistas, sem dúvida mais sintonizada com os princípios liberais do respeito à pluralidade e valorização da dissidência como meio de chegar à verdade, e outra essencialmente repressiva. Esta, como foi dito, modificou-se ao longo do período, acompanhando a transição dos governos e a construção e o fortalecimento das instituições políticas e jurídicas do país.

Num primeiro momento, quando o país acabara de emancipar-se da tutela portuguesa, as os limites dos direitos e liberdades individuais, neste caso a de expressão, ainda estavam indefinidos, e por este motivo assiste-se a grandes debates entre diferentes correntes liberais sobre quais eles deveriam ser. A disputa se deu fundamentalmente entre posições que defendiam um espectro variado de liberdade para a imprensa, mas nunca se cogitou não regular sua atividade.

Foi a indefinição política e institucional, também, que permitiu ao primeiro Imperador e aos seus ministros utilizarem-se de medidas de exceção contra seus 
opositores, inclusive os da imprensa. Dessa forma, os conflitos políticos iam sendo mediados por decretos cujas funções iam desde a proclamação da lei que deveria reger a atividade periodistíca até a instauração de sumários processos policiais e judiciais contra os acusados pelo governo de comprometer a paz e ordem públicas, como as devassas de 1822 e 1824.

Com a abdicação, o poder executivo deixa de ser predominante no sistema político, e vê fortalecerem-se as instituições eletivas liberais, como a Câmara e a magistratura eleita. É quando se torna impraticável a recorrência a medidas extralegais semelhantes às tomadas durante o Primeiro Reinado, o que deixa o governo com poucas opções para conter a oposição exercida pela imprensa. Trata-se também de um momento no qual já está relativamente consolidada a legislação que trata do assunto, e sua reforma não era cogitada politicamente. O enfoque, então, caiu sobre o judiciário, que recebeu instruções a respeito de como deveria proceder nestes casos e ampliando a capacidade de condenar jornalistas criminosos. 


\title{
Capítulo 4
}

\section{Publicidade dos atos da Câmara}

\begin{abstract}
“A publicidade é o asilo da franqueza contra o poder injusto. (...) a opinião pública, uma vez senhora da causa, julga soberanamente e cedo ou tarde suas determinações são executadas. É nestes grandes debates, que ela faz brilhar sua justiça e poder" (Jornal do Commercio, 9/5/1829)
\end{abstract}

Como já foi dito, a publicidade dos atos governamentais é uma característica fundamental dos regimes constitucionais representativos. Segundo Habermas, essa exigência tem efeitos muito mais amplos do que o desejo de tomar o poder, ou de dividi-lo melhor entre os estratos da sociedade, implicando, em última instância, na renúncia mesma da dominação, pois uma vez que as leis fossem fruto de um debate aberto, racional e informado das coisas públicas, todos poderiam tomar parte nas decisões ${ }^{1}$.

A prerrogativa da publicidade questionava uma das bases da soberania absoluta, uma vez que ao monarca deveriam estar disponíveis práticas que se mantivessem secretas a fim de bem governar. Mas, invertidas as condições de legitimidade das políticas, o segredo de Estado não tinha mais lugar: "Just as secrecy was supposed to serve the maintenance of sovereignty based on voluntas, so publicity was supposed to serve the promotion of legislation based on ratio."2. François-Xavier Guerra, em seu estudo sobre as independências das colônias espanholas, lembrará traço semelhante:

"La exigencia de la publicidad es al mismo tiempo un combate contra el poder absoluto - al que el secreto es consustancial - y una garantía de racionalidad de las decisiones, que pueden así ser examinadas por muchos"”3.

Com a ascensão do Estado constitucional, foi constituído o papel da esfera pública na nova ordem: foram reconhecidos por lei os direitos de livre pensamento e expressão, de liberdade de imprensa, reunião e associação. Também foi confirmado o protagonismo da publicidade dos atos da administração pública, que se tornou um dos

\footnotetext{
${ }^{1}$ Jürgen Habermas, op. cit.,página 52.

${ }^{2}$ Idem, página 53.

${ }^{3}$ François-Xavier Guerra. Modernidad y Independencias: ensayos sobre las revoluciones hispanicas. Madrid; México: Editorial MAPFRE: Fondo de Cultura Económica, 1993. Citação à página 273.
} 
princípios organizacionais dos procedimentos dos órgãos do Estado - para ser considerada válida, qualquer determinação legal devia ser tornada pública ${ }^{4}$, sendo essa um requisito para que se pudesse cobrar a sua observância dos cidadãos.

A publicidade das leis e dos debates que a elas deram origem, além de garantia de sua racionalidade, era também a forma encontrada para permitir que a opinião pública exercesse seu poder de tribunal da sociedade. Este entendimento, explicitado na citação que abre este capítulo, era amplamente vulgarizado e aceito no século XIX, e é passível de identificação muito clara nos discursos dos agentes políticos da época. Guerra, analisando os movimentos de independência latino-americanos, diz que

"Es normal, en esta lógica, que contra la opinión así elaborada [pelo enfrentamento racional de opiniões diversas] no se pueda apelar a ningún otro tribunal más que al "supremo tribunal de la razón y del sentido general de los hombres", es decir, a ella misma. Nadie puede juzgarla, pues es ella el juez supremo ante el cual todo debe comparecer: los valores, las ideas, los comportamientos... Ella es al mismo tiempo legislador y juez supremo" ${ }^{\text {. }}$

Nesta passagem, o autor identifica a dualidade do conceito de opinião pública. Ela legisla, ao expor publicamente seus argumentos e arrazoados para que, a partir do confronto entre visões diferentes e da inevitável emergência do consenso em torno da verdade social que nele é revelada, sejam tomados em conta pelos responsáveis pela feitura das leis. É mais legiferante ainda quando se tem em mente que, para o liberalismo doutrinário, o parlamento representativo é ele próprio a corporificação da Nação, ou seja, uma seleção do que há de melhor da opinião pública. Ao mesmo tempo, a opinião pública julga - os ministros, o governo, os representantes, e mesmo outros cidadãos, e espera que seu veredicto seja cumprido, pois sua legitimidade era incontestável. Essa 'onipotência' do conceito mostra a profundidade da transformação do paradigma da política, do segredo para a publicidade, ou da legitimidade de um para a da nação (ainda que, obviamente, não corresponda direta ou estritamente à realidade das articulações políticas).

\footnotetext{
${ }^{4}$ Continuaram a existir alguns poucos assuntos em que o sigilo era utilizado, especialmente alguns aspectos das questões externas, como os ligados diretamente à segurança nacional, declaração de guerra e celebração de tratados, mas eram poucos e referentes a um domínio que até hoje, nas democracias, é altamente insulado da participação popular - a diplomacia - e por essa especificidade não será analisado aqui.

${ }^{5}$ François-Xavier Guerra, op. cit, página 271.
} 
Keith Michel Baker cita Malesherbes ${ }^{6}$ para ilustrar essa mesma concepção:

"un tribunal indépendent de toutes les puissances et que toutes les puissances respectent... ce tribunal du public... le juge souverain de nombreaux autres appels de provenances multiples à ce même tribunal. C'était l'ultime cour - “ ce Juge suprême auquel les Tribunaux les plus absolus sont subordonées, l'opinion publique (...)",

Mas provavelmente quem mais explorou a (auto) definição da opinião pública como tribunal da sociedade foi Reinhart Koselleck ${ }^{8}$. Analisando filosoficamente o movimento iluminista, o autor diz que seu triunfo (ao qual está intrinsecamente relacionado o surgimento de uma esfera pública) está ligado à expansão progressiva do foro interior privado dos súditos para o domínio público que, sem renunciar ao seu caráter privado, torna-se o fórum da sociedade. Este foro interior era aquele reservado à moral, em contraposição ao foro público da política, divisão que teria sido operada pelo Estado absolutista, que, encarregado de proteger os indivíduos de uma violência generalizada (as guerras de religião), fê-lo expropriando destes qualquer capacidade política, que lhe era exclusiva. Aos súditos restava a moral, totalmente separada da política, como categoria de compreensão do mundo. A resposta específica do cidadão a esse alheamento foi justamente o ato de julgar moralmente os atos do Estado e é dele que vem a crença iluminista na reivindicação de valores universais, visando ao fim da dominação política enquanto tal e buscando espaço para o governo da razão. A moral, separada da política - e assim apolítica -, ganhava a legitimidade necessária para julgála justamente por conta de seu distanciamento: "o tribunal moral transforma-se em crítica política, não só por submeter a política a um juízo severo, mas também, pelo contrário, por separar-se como instância que tem a faculdade de julgar o domínio da política"9. É justamente sua pretensão apolítica (de racionalidade, de isenção) que fundamentava a verdade na qual a crítica moral deveria chegar.

Além da questão da publicidade dos atos do governo, o estudo dos anais da Câmara tem interesse por se tratar de uma análise da produção do próprio documento histórico, ou seja, da transmissão da memória coletiva entre as gerações de uma

\footnotetext{
${ }^{6}$ Guillaume-Chrétien de Lamoignon de Malesherbes (1721-1794), censor da imprensa entre 1750 e 1768 , ministro de Luis XVI em 1775, tratadista e escritor político.

${ }^{7}$ Keith Michel Baker. "Naissance de l'opinion publique", in Annales ESC, jan-fev 1987, nº1, pp. 41-71, página 58.

${ }^{8}$ Reinhart Koselleck. Crítica e crise. Uma contribuição à patogênese do mundo burguês. Rio de Janeiro: EDUERJ, Contraponto, 1999.

${ }^{9}$ Reinhart Koselleck, op. cit, página 92.
} 
sociedade. Segundo Jacques Le Goff, questionar os documentos produzidos por determinado período histórico implica em traçar as relações de poder que determinaram sua produção e conservação ${ }^{10}$ e, como se verá, é possível identificar, a partir dos debates, algumas relações de lealdade entre políticos e jornalistas, assim como os interesses que as permeavam.

Políticos brasileiros do século XIX, tanto senadores quanto deputados, também fizeram, em outros termos, uma discussão sobre os preceitos do sistema representativo que englobava as categorias 'opinião pública' e 'publicidade'. Em ambas as casas legislativas foi reconhecida a necessidade de publicação dos debates, projetos e leis a fim de que a população pudesse se informar a respeito de suas atividades - inclusive, senado e câmara tinham comissões de redação dos Diários, específicas para tratar do assunto. Este capítulo analisará os modos pelos quais a Câmara dos Deputados tentou fazer com que seus trabalhos fossem divulgados, pois foi durante as suas discussões que foram enunciados princípios importantes que deveriam guiar a ação dos parlamentares neste aspecto. A publicidade dos atos de governo, repetidamente afirmada como pilar do regime, movimentou conjuntamente interesses políticos e econômicos, mobilizando novos tipos de lealdade e relacionamentos políticos.

O deputado Lino Coutinho ressalta com clareza a relação entre representação e publicidade que é expressa nesses debates durante uma discussão sobre os meios de melhorar o estado da taquigrafia no país:

"Se é certo que a publicidade é a alma do sistema representativo, como queremos acabar com o meio [a atividade taquigráfica da câmara] mais eficaz de fazer efetiva essa publicidade?"11.

É claro que outros elementos do regime também são lembrados, em momentos diversos, como essenciais, mas isso não invalida a suposição na qual se apóia esta afirmação - a de que a publicidade dos trabalhos das câmaras era uma preocupação real dos parlamentares, originada do empenho em fortalecer o regime monárquico representativo

\footnotetext{
${ }^{10}$ Jacques Le Goff. Documento/Monumento. In História e Memória. Campinas: Editora Unicamp, 2003.

${ }^{11}$ ACD, sessão de 13/4/1829, pg. 33, grifo meu.
} 
no país. E ainda é importante ressaltar que, a exemplo da liberdade de expressão da opinião, não se levantam vozes contrárias quando se afirma o direito dos cidadãos à ciência do que se passava no parlamento.

A importância da publicação foi expressa especialmente em termos de proteção das instituições representativas contra os ataques de seus inimigos, especialmente os absolutistas. O padre Custódio Dias, por exemplo, usa cores carregadas para delinear essa imagem:

"É necessário levar ao público o conhecimento dos nossos trabalhos. Nós não temos só inimigos externos, também os temos internos, que são todos esses homens desprezíveis, esse bando de répteis opostos ao sistema constitucional, estes é que querem fazer-nos todo o mal, desacreditando-nos com o povo (...). É necessário que se dê a estes homens toda a ilustração, porque eles estão armados, e os deputados não têm armas"12.

Ela aparece com os mesmos elementos no parecer da Comissão de Redação de 31 de outubro de 1827:

“A comissão de redação do Diário desta câmara não se tem poupado a trabalhos para os pôr em dia, como exigem os interesses nacionais, e a sua reputação; principalmente depois que os absolutistas promotores da anarquia têm assoalhado que nossos trabalhos não vão de acordo com a Constituição do Império" ${ }^{\prime 3}$.

No ano seguinte, durante a discussão do orçamento do ministro do Império, o brigadeiro Raimundo José da Cunha Matos, representante de Goiás, defende a garantia de recursos para a formação de taquígrafos relacionando seu trabalho com a defesa da ordem constitucional: "A taquigrafia é uma barreira contra os propagadores de doutrinas do absolutismo, e ainda mais contra os furiosos caluniadores que desfiguram aquilo que aqui dizemos" ${ }^{\prime 14}$.

E finalmente Lino Coutinho, defendendo também os gastos com os taquígrafos durante a aprovação do regimento da redação dos diários, exprime a mesma visão:

\footnotetext{
${ }^{12}$ ACD, 15/6/1826, pg. 140.

${ }^{13}$ ACD, 31/10/1827, pg. 157.

${ }^{14}$ ACD, sessão de 19/8/1828, pg. 111.
} 
"Se acabarmos com a taquigrafia, temos dado um passaporte aos inimigos do sistema para o tornarem odioso, caluniando os deputados liberais, e apresentando ao povo como emitidas nessa câmara doutrinas que ninguém aqui professa"15.

A funcionalidade dos diários residia, nos primeiros anos do império, primordialmente no seu papel na disputa política contra os partidários de um governo absoluto (ou, se não tanto, pelo menos defensores da predominância política do monarca): publicando os trabalhos das câmaras, seria possível que a população acompanhasse a criação das leis e a defesa de seus direitos, o que levaria à sua adesão aos valores do sistema representativo conforme comprovasse que o parlamento servia aos seus interesses; ao contrário, manter os cidadãos alheios ao que se passava no legislativo garantia espaço para que os opositores do regime angariassem apoio, pois lhes seria possível imputar palavras e ações falsas aos deputados. A preocupação com a publicidade inscreve-se, dessa forma, num esforço maior de catecismo político da população, ainda pouco instruída nos assuntos do poder, a fim de assegurar o fortalecimento das instituições representativas.

Outro argumento a favor da publicação dos trabalhos da Câmara era a necessidade de informar os eleitores a respeito da atuação dos seus representantes. Importava aos deputados dispor de um veículo confiável para tanto, pois sua reeleição podia depender disso, não sendo incomuns as queixas de que um e outro jornal estariam deturpando as declarações dos parlamentares. Na mesma sessão citada acima, Lino Coutinho reclamava: "Ainda ontem o Analysta atribuiu-me coisas que eu não disse nesta casa; (...) mas se não houver taquígrafos, com que se possa desmentir essa gente, o que não farão os Analystas e outros?" "16 . Em outra ocasião, Custódio Dias faz o mesmo tipo de queixa:

"É bem palpável o quanto é necessário adiantar a redação do Diário: os redatores de periódicos que têm apresentado algumas falas dos srs. Deputados, as têm publicado com calúnia manifesta, dando louvores àqueles que não os tiveram" $" 17$.

\footnotetext{
15 ACD, sessão de 13/4/1829, pg. 33.

${ }^{16}$ Idem, ibidem.

${ }^{17}$ ACD, sessão de 17/5/1827, pg. 112.
} 
Além de inquietação a respeito das eleições futuras, essas afirmações também podem ser entendidas como defesa contra as investidas dos opositores da Câmara, uma vez que grande parte dos jornais acusados pelos deputados de modificarem os discursos é por eles classificados como 'do governo' ou mesmo absolutistas, como é o caso do Analysta. A liberdade de imprensa trazia consigo a necessidade para os parlamentares de terem também uma voz impressa que divulgasse sua atuação, de modo a fazer um contraponto aos jornais que lhes fizessem oposição. A publicidade não era portanto uma questão meramente doutrinária, mas uma arma política no contexto de um regime em que a disputa se dava em espaços públicos.

Uma sugestão de Holanda Cavalcanti ${ }^{18}$ a respeito do formato que deveria ter a publicação dos trabalhos da câmara suscitou discussão interessante sobre a liberdade dos parlamentares no sistema representativo. Em 15 de junho de 1826, o deputado toma a palavra para defender a urgência na divulgação dos trabalhos da Câmara, não só na Corte como em todo o país, pois

"Desgraçadamente, anda a sua notícia [dos trabalhos] muito demorada; e o que acontece é que um redator particular encarrega-se de apresentar ao público estes trabalhos, sem escrupulizar na sua exatidão, quando de propósito não faça aparecer coisas mui diversas das que aqui se passam; O Diário Fluminense meteu-se ultimamente nessa tarefa (...). Creio pois que é da maior importância que os nossos trabalhos se apresentem o quanto antes por essa mesma câmara, e que sejam logo espalhados pelas províncias do Império" ${ }^{\text {19. }}$.

Sua proposta era que se publicassem somente as atas, que ficavam prontas e poderiam ser distribuídas ao público mais rapidamente. Mais à frente, respondendo uma objeção de Bernardo de Vasconcelos, o deputado explicita seu receio:

“[os jornais] Levam às províncias idéias falsas dos deputados, e podem fazernos perder toda a confiança. Se nós cumprimos ou não com nossas obrigações, saiba-o a nação, mas por um meio verídico, por um Diário competente, e não por um escritor particular",20.

\footnotetext{
${ }^{18}$ Antônio Francisco de Paula e Holanda Cavalcanti de Albuquerque, deputado por Pernambuco.

${ }^{19}$ ACD, sessão de 15/6/1826, pg. 136.

${ }^{20} \mathrm{ACD}, 15 / 6 / 1826$, página 137.
} 
Manoel José de Souza França, representante do Rio de Janeiro, é um dos que consideravam improfícua a sugestão de Cavalcanti, pois as atas não traziam os discursos, somente as resoluções do parlamento:

"Se o público quisesse saber unicamente das resoluções da Câmara bem, remediava-se o mal; mas quando se compram as folhas é para se ver os discursos dos oradores, é para saber-se a energia com que falou este ou aquele deputado, e não pelas resoluções" ${ }^{21}$.

Almeida e Albuquerque questiona essa afirmação lembrando a prerrogativa de independência dos deputados no sistema representativo:

"O ilustre deputado o Sr. Souza França diz que o povo o que quer saber são as falas dos deputados; e eu digo que é o que não quer saber, ou o que não deve querer, porque o deputado é livre em emitir as suas opiniões, e deve poder dizer o que quiser; aliás ninguém quereria ser deputado [se assim não fosse]: as decisões da câmara é o que ele deve saber (...)"22.

Albuquerque se referia à independência garantida aos deputados no exercício de suas funções; enquanto parlamentar, não era delegado do seu eleitor, não exercia um mandato imperativo. Ao mesmo tempo afirmava a liberdade de opinião do deputado, que não deveria ser cerceada pelo povo e, no seu entender, a divulgação dos discursos acabaria sendo uma forma de cerceamento desta liberdade. A publicidade neste caso, ao contrário da visão expressa por outros deputados, é encarada como limitante do exercício da política, pois a possibilidade de ter seu discurso divulgado coibiria a livre expressão do parlamentar. . Fica explícita a tensão entre a liberdade parlamentar em relação aos eleitores, componente aristocrático da representação, e a liberdade que todo cidadão tinha de se informar a respeito da atuação daquele que elegeu, componente democrático - o eleitor não podia censurar o deputado pelas opiniões que emitia durante o exercício de seu mandato. O problema deste raciocínio é que ele se choca com a liberdade de expressão (e, no limite, com a própria liberdade de imprensa) garantida ao cidadão, e para a qual era prerrogativa fundamental a disponibilidade das informações sobre a atuação do governo e de seus representantes. Essa questão não é notada pelos parlamentares, mas de qualquer forma não passa a sugestão de Cavalcanti.

\footnotetext{
${ }^{21}$ ACD, idem, pg. 138.

${ }^{22}$ ACD, idem, ibidem.
} 
$\mathrm{O}$ aceite geral da importância da publicidade para o sistema representativo, no entanto, não eliminou automaticamente a oposição à publicação dos debates da Câmara, que era custosa ao tesouro público e tinha, em geral, pequena procura depois de impressa. Em 5 de maio de 1830, Luiz Cavalcanti ${ }^{23}$ coloca-se contra a manutenção dos diários, pois se publicavam falas erradas ou nunca ditas e não era possível manter a publicação em dia. Holanda Cavalcanti, mantendo sua posição quanto ao tema, concorda: "a redação dos diários é um grande mal para o Brasil; quem os lê? Ninguém. (...) Quem quiser saber o que se passa aqui, compre esses diários que espalham esses discursos" ${ }^{, 24}$. No dia 6 de julho do mesmo ano, o deputado apresenta formalmente um requerimento para que cessasse a publicação dos diários, assim justificado: "é necessário que cesse a impressão dos diários que mais servem de nos desacreditar do que de utilidade, e mesmo para o aumento das rendas públicas convém que não se continuem tais despesas" ${ }^{25}$. Foi apoiado por Paulino de Albuquerque, que frisa os erros nos discursos.

A sugestão levanta diversas vozes contrárias. Evaristo da Veiga afirma:

“Sr. Presidente, é necessário que não só a província do Rio de Janeiro, como todas as outras mais, saibam o que aqui discutimos; se acaso não houverem diários da câmara, as províncias todas ficarão ignorando as nossas discussões e seus resultados"26.

E completa na discussão seguinte:

“isso [acabar com a impressão] seria privar-nos do único meio que temos de fazer públicos os nossos trabalhos, e então também são desnecessárias as galerias, mandem-se fechar porque não são precisas, ou mande-se deixar apenas dois buracos para só nos ouvirem dois homens, depois eles irão dizer pela cidade o que nós dissemos aqui, isso é admissível? Os nossos discursos devem ser sabidos por todo o Brasil, que nos escuta e deseja saber as nossas opiniões $(\ldots)^{p, 27}$.

\footnotetext{
${ }^{23}$ Luiz Francisco de Paula Cavalcanti de Albuquerque, deputado por Pernambuco.

${ }^{24}$ ACD, sessão de 5/5/1830, pg. 73.

${ }^{25}$ ACD, 6/7/1830, pg. 42.

${ }^{26}$ ACD, sessão de 5/5/1830, pg. 74.

${ }^{27}$ ACD, 6/7/1830, pg. 43.
} 
Francisco de Paula Souza e Melo, deputado paulista, faz uma concessão à crítica da qualidade dos diários, mas mesmo assim combate a idéia de suprimi-los:

"Eu sou da opinião do ilustre deputado [Luiz Cavalcanti]. Os nossos diários tais quais têm saído de nada servem; mas daqui não se infere que não haja diários, porque cumpre não só que o Rio de Janeiro, mas o Brasil todo saiba do que nós fazemos"28.

Ambos os deputados enfatizavam a necessidade de espalhar o conhecimento dos trabalhos parlamentares por todo o império, o que não poderia acontecer caso se dependesse somente do que era publicado nos jornais da Corte, que normalmente tinham circulação pequena em outras províncias, quando o tinham. A publicação e distribuição, pela própria Câmara, dos diários, eram necessárias para que as elites provinciais fortalecessem seus laços com a capital, comprovando que seus interesses e opiniões eram, se não contemplados, pelo menos considerados - dessa forma, a publicização dos trabalhos da Câmara materializava, nas províncias, o papel agregador e negociador da representação nacional, o que, por sua vez, trabalhava em favor da manutenção da unidade do país.

No que diz respeito ao custo de imprimir os diários, não há resposta a Holanda e Luiz Cavalcanti. Mas Custódio Dias, um ano antes, já havia argumentado no sentido de que a despesa não deveria ser motivo para a interrupção das publicações:

"É preciso tratar desta questão, pois da parte da oposição à constituição há muita vontade de que não haja diário. A despesa não deve assustar-nos, porque quanto se gasta em diários é em proveito público"29.

Não passa despercebido o uso do termo público: como força política, já não pode mais ser desconsiderado, é a contrapartida do governo de poucos à soberania de todos; ao mesmo tempo força motriz e destinatário das decisões políticas, seus interesses devem ser o guia para a atuação dos representantes. O "proveito público" a que se refere o deputado reside na proteção da ordem constitucional (e, conseqüentemente, na defesa de sua própria existência). De maneira inversa ao seu raciocínio, a distribuição dos diários das câmaras seria, como já foi dito, um recurso a mais na luta contra os absolutistas, por

\footnotetext{
${ }^{28}$ ACD, sessão de 5/5/1830,pg. 74.

${ }^{29}$ ACD, sessão de 22/4/1829, pg. 36.
} 
levar ao conhecimento da população os trabalhos parlamentares e assim formá-la contra suas investidas. Dessa forma, a consideração do gasto devia ser política, e não econômica.

Mas mesmo quem advogava o fim da impressão, como os Cavalcanti, não era contrário à contratação de taquígrafos, pois os discursos deviam ser colhidos, arquivados e disponibilizados a quem os quisesse consultar. Surgem duas visões a respeito do assunto: de um lado, os que defendiam a impressão e distribuição dos diários, que consideravam que as tarefas relativas à publicidade deveriam ser empreendidas ativamente pela câmara; de outro, aqueles que enfatizavam que a iniciativa de conhecer o que ali se passava deveria partir dos interessados nisso. São os primeiros que invocavam a necessidade de informar a todas as províncias dos trabalhos parlamentares, no sentido do fortalecimento dos laços entre elas e a capital, por meio da demonstração de uma unidade política em torno do sistema representativo; os últimos lembravam o alto custo que os diários representavam à fazenda pública, injustificável face ao número restrito de leitores efetivos, e também se escudavam com o grande número de erros e deturpações trazidos por esses impressos, defendendo sua extinção por seu potencial "desinformativo".

É notável a ausência de uma preocupação explícita com a memória da Câmara dos Deputados; nenhum dos deputados parecia considerar que os Diários seriam agregados à massa documental produzida por sua época - talvez a sugestão de Holanda Cavalcanti sugerisse algum raciocínio do tipo, mas essa é uma mera conjectura. Segundo Fernanda Maia, essa idéia teria ocorrido a alguns parlamentares portugueses: "Embora muito menos generalizada, registramos também a opinião daqueles poucos que, com grande sentido histórico, entreviam já o Diário como um monumento para o futuro e não para consumo imediato" ${ }^{30}$. No Brasil, ao contrário, o atraso da publicação em relação aos debates sempre foi alardeado como um desestímulo à sua leitura, que acabava por inutilizar o registro.

Apesar da votação proposta por Luiz Cavalcanti ter decidido pela manutenção da publicação, em 1832 os diários estavam extintos, o que aconteceu, segundo o deputado maranhense Manuel Odorico Mendes, pela "união promíscua" dos votos da maioria e da

\footnotetext{
${ }^{30}$ Fernanda Paula Souza Maia, op. cit, página 94.
} 
minoria $^{31}$; no entanto, não há registro de qualquer discussão nesse sentido. Ao que tudo indica, continuaram os serviços de taquigrafia e também a transcrição, por alguns jornais, daquilo que consideravam de maior interesse das seções, mas a publicação integral dos trabalhos só seria normalizada em 1839, como se verá a seguir. Durante este intervalo, nota-se que os volumes dos anais da Câmara são bem menores do que costumavam ser, as falhas da taquigrafia são muito mais frequentes e a maioria das falas é apresentada em discurso indireto, como um relato resumido do que fora dito.

Não se pode ignorar que essa descontinuidade se deu justamente durante o predomínio dos liberais moderados tanto na Câmara quanto no governo regencial e, a crer no relato de Odorico, contou com o apoio da oposição. Isto pode indicar que o compromisso com a publicidade dos trabalhos tinha um componente ideológico, com o qual os liberais moderados se afinavam, mas não era partilhado pela oposição, e um pragmático, valorizado anteriormente pelos moderados pelo potencial político da divulgação de seu desempenho nas fileiras contrárias a D. Pedro, mas agora, aparentemente, um tanto desnecessário.

\section{A publicação dos diários}

O primeiro problema enfrentado pelas comissões de redação foi garantir que os Diários da Câmara se aprontassem e distribuíssem em dia, ou seja, viesse a público poucos dias depois da discussão relatada. De início, a solução procurada passava por escolher uma tipografia que desse conta dos trabalhos a tempo. A Tipografia Nacional, estabelecimento do governo que estava então incumbido do serviço, não o fazia de maneira satisfatória, estando sempre a impressão muito atrasada em relação aos debates. O francês Pedro Plancher, que mais tarde seria o primeiro dono e redator do Jornal do Commercio, ofereceu, em 19 de maio de 1826 - logo após a abertura da Câmara, portanto - sua tipografia para a impressão dos debates, cobrando 5\% a menos do que a Tipografia Nacional ${ }^{32}$. O parecer da comissão de redação dos diários não recomendava o contrato, mas sugeria que a câmara o mantivesse sob consideração. Na ocasião, Souza França votou com o parecer, mas aconselhou

\footnotetext{
${ }^{31}$ ACD, 12/7/1832, página 58.

32 Apesar de ser um estabelecimento do governo, a Tipografia cobrava para imprimir os trabalhos da Câmara, e não ocorreu aos deputados que o serviço pudesse ser prestado gratuitamente. A alternativa de exigir do governo que arque com os custos da publicação só será cogitada anos depois, como se verá.
} 
"que se organize o Diário por um ou dois prelos, seria muito melhor do que mandá-lo à tipografia nacional (...). A câmara é como o autor daquela obra, pode tirar o interesse de fazer conhecer com mais prontidão à nação o que ela faz; portanto acho que se deve preferir o meio que apresentar menos demora. É por isso que sou de parecer que esse impressor se entenda com o relator da comissão, para ver também se se poupa à fazenda nacional a despesa dessa impressão, que talvez se possa fazer de graça" ${ }^{\text {"33. }}$.

Lino Coutinho, por sua vez, defendeu a continuidade da parceria com a empresa estatal:

“Sr. Presidente, os negócios da Câmara não devem sempre ser decididos por cálculos econômicos. Bem é que um autor assim se ajuste com qualquer impressor; mas, pergunto eu, ficará decoroso a esta câmara vender os trabalhos dos deputados a um impressor, que os vai passar como um tráfico mercantil? De mais é preciso que esta câmara promova todos os estabelecimentos nacionais, e que faça afugentar convenientemente toda indústria estrangeira (...). Concluo pois que tendo nós uma tipografia nacional não devemos procurar a estrangeira, ainda com as vantagens que se figuram"34.

Batista Pereira também falou, em termos retintos, a favor da manutenção da tipografia nacional:

"Foi sempre a máxima dos estrangeiros enterrar todos os estabelecimentos cujos produtos podem atrasar o seu comércio: por isso compram fábricas só com o intento de as arruinar, o que nós já vimos nesta corte (...). Portanto não convindo em que a nossa tipografia, único estabelecimento deste gênero que vai prosperando no Brasil, tenha semelhante destino, acho que devemos recorrer a ela para imprimir o expediente desta câmara" ${ }^{\text {"3 }}$.

Essa discussão revela a posição, entre alguns deputados, de que o caso não podia ser tratado somente sob seu aspecto econômico, mas também sob o político, que era o apoio a uma indústria nacional em detrimento de estrangeiras. Mostra, assim, o rechaço destes dois deputados ao liberalismo econômico clássico, com a defesa de que o Estado mantivesse seus estabelecimentos produtivos a fim de garantir a nacionalidade de parte

\footnotetext{
${ }^{33}$ ACD, 19/5/1826, pg. 89.

${ }^{34}$ ACD, idem, ibidem.

${ }^{35}$ ACD, sessão de 20/5/1826, pg. 98.
} 
da produção tipográfica. O problema que parecem ignorar, como se verá adiante, é que essa produção não estaria isenta da ingerência política do governo.

A Tipografia Nacional foi objeto de discussão algumas outras vezes, sempre criticada por conta da demora na impressão dos trabalhos a ela confiados: em 8 de maio de 1828, apresenta-se pela primeira vez uma sugestão de arrematação da Tipografia Nacional, que é assim descrita no índice do volume: “indicação do sr. Custódio Dias propondo a sua arrematação por não dar utilidade alguma ao país, servindo antes de veículo para a publicação de obras agressivas das liberdades públicas”. De fato, Dias defende sua indicação como um meio para "tirar o sustento daqueles que se empenham para que se imprimam calhamaços contra a liberdade que a constituição dá" ${ }^{36}$. Segundo o deputado, apenas andavam atrasados os trabalhos e papéis da câmara, enquanto eram publicadas pela tipografia obras que pregavam o absolutismo. A proposta foi apoiada e decidiu-se que se imprimisse para ir à segunda discussão, embora depois não retorne à ordem do dia.

Em 6 de julho de 1830, surge nova proposta de venda da tipografia nacional, elaborada dessa vez pela comissão de orçamento. No dia 16 acontece a discussão do parecer - Custódio Dias e Vasconcelos, respectivamente, apoiaram a venda, afirmando que a tipografia era onerosa demais à nação e não cumpria o intento de imprimir os papéis legislativos:

"Como hoje apareceu o parecer da comissão, devemos dar-lhe direção e acabar com esta tipografia que se acha muito mal administrada, e como pode ela ter boa administração? De maneira alguma, administrações do governo são quase sempre assim (...). Esta tipografia é onerosa à nação, porque alugado o edifício render-nos-ia muito mais do que ela. São além disto patentes os males que dali têm provindo, que nos têm muitas vezes empatado, e se ela não nos faz mal é porque não pode. Tem-se paralisado a impressão dos diários desta câmara e a impressão dos orçamentos dos anos pretéritos, enfim é mister abolir o estabelecimento. As outras imprensas entrando em concorrência hão de querer por especulação tomar a seu cargo e por preços razoáveis as impressões do governo (...) $)^{37}$.

\footnotetext{
${ }^{36}$ ACD, 8/5/1828, pg. 26.

${ }^{37}$ ACD, sessão de 16/7/1830, pg. 136.
} 
"Devemos ter mais em atenção os bons resultados que se seguirão de se imprimirem os papéis, tanto do governo como das câmaras, em outras tipografias, que de certo terão maior publicidade, pois que ora morrem na tipografia nacional; e se não apresente-se a conta da importância das câmaras legislativas que têm sido vendidos pela tipografia? Ao menos todos os papéis que têm por fim a sustentação da constituição, lá não se imprimem"38.

As falas de Dias e Vasconcelos revelam, por sua vez, a defesa de uma perspectiva cara ao liberalismo econômico: a desconfiança quanto à capacidade de boa gerência de estabelecimentos produtivos pelo governo, a defesa da concorrência entre outras empresas como meio para garantir o melhor preço para a Fazenda pública. Mas também exprimiam as disputas que então opunham parlamentares e executivo, ao acusarem a Tipografia de trabalhar para os fins do governo, soltando impressos que defendiam a predominância do monarca no sistema político e, ainda, dificultando a vida legislativa ao atrasar (ou simplesmente não imprimir) a saída de documentos fundamentais como os orçamentos ou projetos de lei.

Além de não cumprir os prazos para a impressão dos trabalhos, a tipografia era acusada pelos deputados de dar preferência obras destinadas a perturbar a ordem constitucional, crítica que se repetirá mais a frente.

Holanda Cavalcanti está entre os que defendiam a reforma da administração:

"O que nos convém é a publicidade dos impressos da nação com exatidão e até distribuídos grátis por uma grande parcela de indivíduos da sociedade. Em todos os governos onde progride o nosso sistema existem tipografias por conta do governo, porque a sua utilidade é incalculável (...). Entretanto sua má administração não induz que não seja útil ao nosso sistema conservar esse estabelecimento: o ministério até pode aproveitar-se dele, isto é, ter uma folha para levar a administração àquele fim a que deve chegar (...). Concluo pois votando contra a venda da tipografia, à vista das muitas utilidades que ela oferece com uma boa reforma (...),39.

\footnotetext{
${ }^{38}$ ACD, idem, página 137.

39 ACD, idem, ibidem.
} 
Miguel Calmon du Pin e Almeida, deputado da Bahia, relembra a função política do estabelecimento:

"é inegável que a tipografia imprime mais barato, o que é de sua natureza, e todos sabem que não entra nos cálculos da nação interesse comercial com a tipografia (...). Entendo que a proposta do governo [de reforma da administração] deve passar, e não me cansarei em provar a necessidade de um estabelecimento tipográfico em um governo representativo que tem por alma a publicidade de seus atos" $"$.

A reforma administrativa venceu a proposta de venda, o que significa o reconhecimento dos vícios da administração da tipografia, embora, ao contrário do defendido por Custódio Dias, não fossem considerados inerentes à administração estatal dos estabelecimentos, sendo, por isso, passíveis de emendas que garantissem o bom funcionamento da empresa. Ainda assim, não se discute em que consistiria essa reforma, e nem mesmo as acusações de manipulação pelo governo chegam a criar qualquer polêmica entre os parlamentares, o que sugere que a vitória dessa proposta significava apenas a manutenção do status quo.

Em 30 de julho do mesmo ano, devido à demora da Tipografia Nacional em imprimir até os projetos de lei a serem discutidos, Costa Aguiar, apoiado por muitos outros deputados, sugeriu que a Assembléia Nacional adquirisse sua própria tipografia:

"Não seria melhor e até mais decente à Assembléia Geral obtermos nós uma imprensa onde se imprimissem com a brevidade possível todos os diários, projetos, pareceres e mais papéis da assembléia geral? (...) Sem essa medida que eu lembro (...) nada faremos: os nossos trabalhos serão sempre envoltos no véu da obscuridade, e mal poderão chegar ao conhecimento dos constituintes das mais remotas províncias do império, o que tudo tem importado até aqui talvez essa indiferença, com que o sistema é ainda olhado por alguns “indiferentistas" ou egoístas",41.

Cunha Matos defendeu ironicamente a Tipografia, dizendo que

\footnotetext{
${ }^{40}$ ACD, sessão de 16/7/1830, pg. 138.

${ }^{41}$ ACD, 30/7/1830, pg. 217.
} 
“ela é muito boa: porém, está sobrecarregada de obras de muita consideração, catecismos muito interessantes ao povo do Brasil, e papéis sustentando as opiniões da honra do Brasil desagravada da Astréa Espadachina (...) era melhor que esses homens que escrevem papéis que na impressão têm preferência ao meu projeto não se cansassem nos seus trabalhos; debalde se afadigam, todos os conhecem, é já tarde; não ignoramos quais são os seus fins sinistros, podem ficar certos de que nunca alcançarão o que desejam, o Brasil há de ser livre, é um império constituído com um governo monárquico-hereditáriorepresentativo, este laço é eterno, é indissolúvel (...)"42.

A descrição dos outros fregueses da tipografia nacional reforça o dito anteriormente por Custódio Dias, que a oficina se dedicava a imprimir escritos 'absolutistas'. Cunha Matos apoiou a sugestão de uma tipografia própria das câmaras, inclusive atribuindo ao seu patriotismo a disposição de concorrer para isso com os meios de que dispusesse. Apesar do apoio de outros deputados, a câmara não aprovou indicação nesse sentido.

É só em 1834 que surgiu a opinião formalizada (Souza França já tinha dito isso, sem encaminhar sugestão escrita, em 1828) de que seria mais proveitoso terceirizar os trabalhos de publicação. Na sessão preparatória do dia 2 de maio, Evaristo da Veiga, relator da comissão nomeada para sugerir o melhor método para a redação do diário apresentou a solução encontrada: terceirizar as funções de administração e taquigrafia para empresários que se dispusessem a tanto. Holanda Cavalcanti se opôs, defendendo sua antiga idéia de que os discursos deveriam ser colhidos, mas não impressos. Apesar do apoio ao parecer, no dia 12 de maio a proposta da comissão foi derrotada na votação. No entanto, a falta de opções para a impressão e distribuição satisfatórias dos diários, aliada ao trabalho que alguns jornais já vinham realizando de maneira autônoma, fez com que o parlamento acabasse por celebrar um contrato com o Jornal do Commercio para regularizar a publicação de seus trabalhos na folha.

Não era nenhuma novidade que os jornais dedicassem um espaço razoavelmente grande de suas páginas ao relato das sessões da Câmara e do Senado, assim como de reuniões menos importantes, como as de conselhos de jurados. Como entre os deputados, parecia existir consenso entre os redatores de que havia interesse por parte do público no conhecimento dos debates. $\mathrm{O}$ fato de a primeira discussão sobre a

\footnotetext{
${ }^{42}$ ACD, idem, pg. 217-218.
} 
acessibilidade dos trabalhos parlamentares ter ocorrido por conta de um requerimento do jornal Diário Fluminense para que um de seus funcionários tivesse permissão de assistir às sessões a fim de tomar notas e publicá-las na folha, parece confirmar essa hipótese. O parecer da comissão de redação do Diário, a quem coube avaliar o pedido ${ }^{43}$, reafirma a posição dos parlamentares, assim como as intervenções de Lino Coutinho e Vasconcelos no sentido de estabelecer ainda que a decisão estender-se-ia a todos os outros periódicos que desejassem.

Apesar disso, a relação da Câmara com as folhas que publicavam seus trabalhos foi tensa durante todo o período analisado. O mesmo Diário Fluminense, junto com alguns outros, foi alvo de grandes críticas por parte dos deputados, que os acusava de deturpar as falas proferidas, como já foi discutido acima. Mas, de qualquer forma, confiar a publicação dos trabalhos aos jornais parece ter sido a melhor maneira de tornálos públicos. Foi durante os períodos de vigência do contrato entre a Câmara e o Jornal do Commercio (1839-1847 e 1850-1855, para esta pesquisa) que os anais da Câmara estão mais completos, com menos falhas de transcrição ou lacunas nos discursos. Depois dessa primeira experiência, não ocorre aos deputados retornar à contratação direta dos taquígrafos e tipografias, mas sim escolher novamente jornais dispostos ao serviço e capazes de oferecê-lo com destreza.

Apesar de a indicação para que se terceirizasse a publicação dos diários ter sido derrotada em 1834, a idéia surge novamente em 22 de setembro de 1837, quando o representante de Minas Gerais Honório Hermeto Carneiro Leão propõe que a câmara torne público que oferecerá quatro contos ao jornal que melhor publicar as discussões da sessão ordinária de 1838. Fala que o Jornal do Commercio, tendo se proposto a isso sem cobrar nada, passou a fazê-lo após reconhecer a importância da tarefa e, não recebendo, cessou a publicação, sem ver diminuído seu número de assinaturas ${ }^{44}$.

Em 22 de maio de 1839, foram apresentadas à câmara propostas dos jornais $O$ Despertador $^{45}$ e Jornal do Commercio. Contra o primeiro, são apresentadas as queixas freqüentes dos senadores, já que era o contratado para publicar os seus trabalhos, o que

\footnotetext{
43 “A comissão, julgando que convém vulgarizar, quanto for possível, os debates da Câmara, para que a nação ajuíze do fervor com que são defendidos os seus direitos e promovida a sua felicidade" (ACD, 18/5/1828, pgs. 84-85).

${ }^{44}$ ACD, sessão de 22/9/1837, páginas 557-558.

${ }^{45}$ Redigido pelo então liberal Francisco Sales de Torres Homem, deputado nas legislações de 1842, 1845 e 1848, depois ministro da Fazenda do gabinete conservador de 1858, Visconde de Inhomirim e senador.
} 
garantiu ao segundo grande apoio dos deputados. A decisão do dia autorizava o pagamento de 1:600\$ ao jornal contratado, mas não determinava qual deles seria, dando espaço para que a mesa negociasse e trouxesse sua sugestão à Câmara, que deveria aprovar o contrato. Assim, em 5 de junho, a Câmara dos Deputados firma um contrato com os editores do Jornal do Commercio, no qual se compromete a pagar mensalmente 1:600\$ por todo o processo de publicação das sessões, desde o colhimento dos discursos até a sua publicação no exemplar dos dias seguintes. As duas partes também combinam um aviso prévio de 30 dias para rompimento do contrato, e à mesa diretora da câmara é atribuída a tarefa de fiscalizar o trabalho do jornal. A partir de então, quando se discute a publicidade dos debates, fala-se fundamentalmente da relação entre a câmara e o periódico, e por isso vale expor algo de sua história.

O Jornal do Commercio era uma folha diária, fundada em 1827 por Pierre Plancher, um francês chegado ao Brasil em 1824, fugido da restauração dos Bourbons na França. Por ser o editor de Benjamin Constant em sua terra natal, logo caiu nas graças de D. Pedro I, livrando-se das acusações de anarquista e falsário que fizeram com que toda sua bagagem fosse confiscada quando chegou ao Rio de Janeiro e, mais importante ainda, conseguindo para sua empresa o título de "Imperial Tipografia". Fez jus ao favor: o primeiro jornal que editou, O Spectador Brasileiro, circulou entre 1824 e 1827 e era um ferrenho partidário do Imperador e da ampliação de suas prerrogativas legais; inclusive, emprestava suas páginas para que o próprio, sob o abrigo de pseudônimos, atacasse os deputados e a Câmara em geral, e encetava discussões com os periódicos alinhados com os liberais moderados da corte, como a Aurora Fluminense e a Astréa $a^{46}$.

Quando se acirraram as polêmicas com outros jornais, julgou ser mais prudente não se envolver tanto nas disputas políticas do país, e encerrou a publicação. No mesmo ano, surge com outra proposta jornalística, baseada no que já vinha sendo feito pelo Diário do Rio de Janeiro: veiculação de informações sobre o movimento dos portos, preços das commodities negociadas, informações sobre importações e exportações e anúncios, e apenas subsidiariamente informando sobre acontecimentos políticos do país e do exterior ${ }^{47}$. Tentava superar o caráter partidário que a maior parte das folhas tinha à

\footnotetext{
${ }^{46}$ Cícero Sandroni. 180 anos do Jornal do Commercio 1827-2007. De D. Pedro I a Luiz Inácio Lula da Silva. Rio de Janeiro: Quorum Editora, 2007. Esp. páginas 3-135.

${ }^{47}$ Nelson Werneck Sodré, op. cit., página 109.
} 
época, propondo-se 'imparcial'. No entanto, continua com orientação governista, publicando artigos laudatórios às ações ministeriais, correspondências que atacavam a Câmara dos Deputados e noticiavam processos de liberdade de imprensa sofridos pelos jornais dos liberais moderados - com os quais continuava a trocar farpas.

A observação de Cícero Sandroni de que era "patente a dedicação do jornal às classes conservadoras", mas ainda assim mantinha "isenção absoluta" ao relatar os fatos e não participava das lutas e interesses de $\operatorname{partidos}^{48}$ é insustentável mesmo diante de uma análise rápida das páginas do jornal como a que se fará aqui. À guisa de exemplo, é interessante citar um artigo do dia 10 de outubro de 1828, no qual critica a interpretação da lei constitucional veiculada pela Aurora Fluminense: "para ela, todo o interesse, representação e soberania nacional se concentram na Câmara Eletiva" ${ }^{\text {"49 }}$. É claro que Plancher se contrapunha a essa leitura no sentido de reivindicar para o imperador mais importância neste esquema soberano.

O leitor do Jornal também não soube da crise que resultou na abdicação de D. Pedro I, e caso não vivesse na Corte e só se informasse por esta folha, seria surpreendido pela notícia, pois até então o jornal somente relatou o júbilo e alegria dos habitantes de Minas quando da visita do Imperador à província, e o igual entusiasmo dos fluminenses quando retornou à capital ${ }^{50}$. Após a abdicação (que qualifica de "revolução regeneradora") não se alinha com os restauradores, reconhecendo os direitos de D. Pedro II $^{51}$. Apóia as medidas estabilizadoras da regência e até reproduz artigos de folhas antes inimigas, como o Universal de Minas Gerais e a Aurora. Esse alinhamento (precário) com os liberais moderados transparece também pelas notícias de condenação por abuso de liberdade de imprensa, sempre de jornais exaltados ou caramurus. A partir de 1833, sua seção política dedica-se quase que exclusivamente à publicação de decisões, decretos, relatos das sessões da câmara e outros documentos oficiais.

Em 1834, Pierre Plancher afasta-se definitivamente da redação do jornal (já o havia vendido, em 1832, mas ainda colaborava e ditava sua linha editorial) e retorna para a França. Assumem o controle pleno do periódico os também franceses Junius

\footnotetext{
${ }^{48}$ Cícero Sandroni, op. cit, página 43. Em socorro do autor, há de se dizer que este livro, na verdade, é apenas um bem detalhado roteiro laudatório da trajetória do jornal.

49 Jornal do Commercio, 10/10/1828.

${ }^{50}$ Jornal do Commercio, edições de 9/3/1831 e 28/3/1831.

${ }^{51}$ Idem, 12/4/1831.
} 
Villeneuve e Réol Antoine de Mougenot ${ }^{52}$, que manteriam as principais características do jornal. Neste ano, apesar de afirmar não ter nenhuma opinião sobre os méritos dos candidatos à regência una, reproduz diversas correspondências que faziam campanha para Feijó ${ }^{53}$. Como já se disse, a seção de cartas dos leitores era editada de forma a legitimar a posição do periódico a respeito dos assuntos abordados no editorial, e por ser anônima pode-se questionar se não eram os próprios redatores quem, muitas vezes, escreviam os textos. Assim, cai por terra qualquer argumento referente à suposta 'neutralidade' do Jornal do Commercio.

Durante o período regencial, a folha aproxima-se da Câmara dos Deputados, elogiando a postura de alguns de seus membros, sem nunca, no entanto, indispor-se com o poder executivo. Sem dúvida, não se dedicaria à função da imprensa tão defendida por deputados como Bernardo de Vasconcelos e Nicolau Vergueiro, aquela de fiscalizar o governo e a administração pública, denunciando com veemência as irregularidades que encontrasse.

A partir de 1836, começa a publicar com maior regularidade - e sem auxílio pecuniário - os debates da Câmara, o que lhe gabaritaria para pleitear o contrato firmado três anos depois.

Depois de contratado pela Câmara, o Jornal do Commercio teve o valor de sua remuneração ajustado duas vezes. A discussão do primeiro pedido, um acréscimo de $400 \$$ para igualar sua remuneração à recebida pela folha que publicava os trabalhos do senado, traz à tona diversas insatisfações com o jornal. Quando entra em discussão o parecer favorável da mesa, Antônio Carlos, novamente deputado por São Paulo e compondo a minoria oposicionista na Câmara, se opõe, por achar que $O$ Despertador cumpria melhor essa função, por ser mais imparcial:

"Demais, sinto dizê-lo, cuido que este jornal não cumpre tão bem como o Despertador; o Despertador é mais imparcial; o Jornal do Commercio publica os discursos conforme o lado onde são proferidos: os de um lado são sempre dados por extenso, entretanto que outros são extractados ou cortados. Por estas razões eu não votarei pelo aumento, entendo que ele não merece mais" ${ }^{\text {,54. }}$.

\footnotetext{
${ }^{52}$ Cícero Sandroni, op. cit, página 68-69.

${ }^{53}$ Jornal do Commercio, 27 e 31 de março de 1834.

${ }^{54}$ ACD, sessão de 9/6/1841, página 447.
} 
Ao argumento econômico, de aumento dos custos das transcrições e impressão, o deputado opõe uma questão de mérito, politizando a prestação de serviço, que deveria ser isenta. Joaquim José Rodrigues Torres, deputado pelo Rio de Janeiro, e o magistrado pernambucano Joaquim Nunes Machado, respectivamente, discordam da avaliação negativa e defendem o ajuste:

“(...) acho que alguma razão tem o editor do Jornal do Commercio em querer que se iguale o seu subsídio ao que recebe o jornal da outra câmara. Em verdade, eu não creio que $O$ Despertador seja mais imparcial que o Jornal, nem que cumpra melhor com a sua obrigação" 55 .

"A respeito de imparcialidade, devo dizer que, se não aparecem com toda a extensão alguns discursos, será porque a empresa tenha entendido que basta serem extractados, por não versarem sobre objetos de muita importância, a fim de haver lugar para se apresentarem por extenso outros sobre matéria de maior consideração. (...) Os trabalhos do Jornal são os mesmos do Despertador, e contra este ouço todos os dias queixas; o ano passado não havia dia em que não aparecesse queixa de um ou outro Sr. Senador contra essa folha"56.

Manoel Maria Carneiro da Cunha, representante da Paraíba do Norte, deixa de lado a discussão da parcialidade e vota pelo aumento:

"não sei como em um país constitucional como o nosso se possa prescindir de um jornal que publique as nossas discussões, pois necessário é que nossos constituintes saibam as nossas opiniões. (...) Portanto, estou resolvido a votar por este parecer da comissão, porque, torno a repetir, é necessário que se vejam as opiniões de cada um dos srs. Deputados, a fim de que se conheça quais são aqueles senhores que mais merecem as simpatias e a aprovação de seus constituintes" ${ }^{\circ 7}$.

Além disso, complementa com a lembrança de que era preciso que se enviassem coleções do jornal às câmaras provinciais, pois

\footnotetext{
${ }^{55}$ ACD, idem, ibidem.

${ }^{56}$ ACD, idem, página 448.

${ }^{57}$ ACD, idem, ibidem.
} 
"no interior de nossas províncias ainda por falta de leitura se não sabe bem apreciar o sistema constitucional, não sabem nada, estão com os olhos tapados ainda a esse respeito, e talvez disso provenham muitos dos males que o país tem sofrido" $" 58$.

Cunha reproduz o grande consenso a respeito da publicidade no governo constitucional construído no parlamento até então: a necessidade de os eleitores saberem das idéias de seus representantes, tanto para que se possam informar para próximas eleições quanto para que se defendam das investidas de grupos que visam a derrubar o sistema, a essa altura não mais os 'absolutistas', mas aqueles que questionam o regime em âmbito local.

Nessa mesma sessão, o prelado D. Manoel do Monte Rodrigues de Araújo, fluminense representante de Pernambuco, faz um discurso a favor do jornal que ajuda a esclarecer a predileção dos deputados por seus trabalhos:

"Eu não venho aqui elogiar os editores do Jornal do Commercio nem os taquígrafos, faço muito poucos discursos; não há, portanto, lugar a ser favorecido na publicação. É verdade que tenho algumas relações com os editores do jornal; com um deles, o Sr. Picot, que se acha sempre atendendo às discussões para redigir os debates, tenho íntima amizade. Todos nós o conhecemos, vejo que muitos srs. Deputados, tanto de um como de outro lado, lhe consagram amizade. O que tenho conhecido nele é o maior empenho, o maior capricho em apresentar devidamente os trabalhos da Casa (apoiado), cumpre reconhecer que tem desempenhado satisfatoriamente esta obrigação. Ora, à vista de tudo isto, não posso deixar de dizer que os editores merecem os aumentos da consignação que pedem"

É curioso que o fato de o deputado "fazer poucos discursos" seja suficiente para afastá-lo da suspeita de favorecer um ou outro jornal. Mas mais importante ainda é a revelação de que o jornalista pertencia ao círculo de amizades de diversos deputados, "de um e de outro lado", que torna mais compreensível o insucesso da oposição na tentativa de desbancá-lo da preferência do parlamento - nesse caso, as relações e lealdades pessoais ficavam acima da política. A pergunta que fica sem resposta é se,

\footnotetext{
${ }_{59}^{58} \mathrm{ACD}$, idem, página 449.

${ }^{59}$ Cícero Sandroni, op. cit, páginas 86-87.
} 
sendo verdadeiras as denúncias de adulteração maliciosa dos discursos de alguns deputados, elas ocorriam igualmente para todos os que defendiam determinadas medidas ou posições políticas ou somente nas falas dos que não esposavam tanta amizade com os redatores ${ }^{60}$.

No dia 11 de junho, o magistrado D. José de Assis Mascarenhas faz um longo discurso sobre a imparcialidade dos jornais e encerra a discussão, por ora, com o argumento de autoridade de um integrante da mesa diretora que merece a confiança de seus colegas:

"Nenhuma condição é mais importante do que aquela que diz respeito à imparcialidade; e se a mesa estivesse convencida de que havia parcialidade, ela seria a primeira a usar do direito que o mesmo contrato lhe confere. Demais haveria ousadia mais inconcebível, um atrevimento mais indesculpável, do que apresentar os discursos de um dos lados tais como foram produzidos, e alterar os outros?"

A votação foi favorável à concessão do aumento.

O segundo aumento concedido aos editores do Jornal do Commercio, de 500\$ sobre o valor que recebiam, foi justificado pela maior duração das sessões, que passaram de 4 para 5 horas, e é aprovado sem discussão ${ }^{62}$.

Durante o período em que vigorou o contrato com o Jornal do Commercio, os deputados receberam diversas propostas de outros jornais interessados no auxílio financeiro que recebia pela publicação dos debates. Isso porque qualquer redator poderia enviar funcionários às sessões para ter também em sua folha os extratos das discussões, o que certamente atraía leitores, mas os custos de tal empreitada eram altos: além do pagamento de taquígrafos e redatores, era necessário apressar a publicação para que estivesse pronta nos dias seguintes e mantivesse seu interesse.

No ano seguinte à celebração do contrato, o diretor d'O Despertador, Francisco de Salles Torres Homem, oferece condições mais vantajosas para a publicação dos debates da câmara, propondo uma remuneração de 1:000\$ pelo trabalho; ao mesmo

\footnotetext{
${ }^{60}$ Se forem verdadeiras, a questão fica mais simples, pois aí provavelmente se tratava de deputados querendo promover seus amigos e lealdades políticas de outros jornais.

${ }^{61}$ ACD, sessão de $11 / 6 / 1841$, página 469.

${ }^{62} \mathrm{ACD}$, sessão de 5/4/1845, página 457.
} 
tempo, solicita que os taquígrafos empregados públicos sejam alocados para a câmara. O parecer da mesa diretora é contrário, tendo em vista o prévio contrato com o Jornal do Commercio, que, não havendo incorrido em nenhuma falha, não deveria ser punido com o rompimento do acordo, além de lembrar que o proponente já havia firmado contrato com o senado ${ }^{63}$. O Despertador era uma folha liberal, pelo menos a julgar pela orientação política de seu redator, e isso não foi empecilho para que o Senado contratasse seus serviços, ainda que alguns senadores reclamassem da folha, como afirmavam os deputados.

Em 1845, é a vez de o jornal $O$ Mercantil $^{64}$ ter sua proposta rejeitada, apesar de pedir um subsídio $200 \$$ menor do que o recebido pelo Jornal do Commercio na época. A mesa, apesar de reconhecer a economia de $200 \$$ que se faria, não julga conveniente nem justo rescindir o contrato com o Jornal do Commercio, que vinha, segundo a mesa, do melhor modo possível cumprindo sua obrigação.

Dois anos depois, Antonio José de Miranda Falcão, administrador da Gazeta Oficial (periódico publicado na Corte “por ordem imperial”), requer à câmara a publicação de seus trabalhos sob as mesmas condições dadas ao Jornal do Commercio, alegando ser a sua folha a de maior circulação no Império ${ }^{65}$. A resposta da mesa é que o Jornal seja avisado de que durante um mês os meios da Gazeta Oficial serão observados, a fim de que se contrate com aquele que mais satisfatoriamente publique os debates $^{66}$. Dessa vez, tratava-se de um periódico do governo, que tinha mais condições de pleitear junto aos deputados o auxílio à publicação de seus trabalhos. O parecer é adiado por haver oposição.

A discussão continua dias depois e Nunes Machado é contrário à rescisão:

“eu estou convencido de que a câmara, sem uma razão muito forte, sem uma prova evidente da perfeição do trabalho [da Gazeta Oficial], não quererá

\footnotetext{
${ }^{63} \mathrm{ACD}, 25 / 5 / 1840$, página 505.

${ }^{64}$ Sobre este periódico, a única informação encontrada, no Catálogo da Biblioteca Nacional, é que circulou entre 1844 e 1847.

65 Nelson Werneck Sodré (op. cit, nota 176, página 258) traça sua linhagem: Gazeta do Rio de Janeiro(1808-1821); Gazeta do Rio (janeiro a dezembro de 1822); Diário do Governo (1823-1833); Diário Fluminense (1824-1831); Correio Oficial (1833-1836; 1830-1840); Gazeta Oficial do Império do Brasil (1846-1848). É claro que se deve ter cautela com sua classificação, pois o autor costuma atribuir oficialidade a muito do que é somente "oficioso", como é o caso da Gazeta do Rio de Janeiro, do Diário do Governo e do Diário Fluminense, que nunca foram órgãos oficiais do governo, e sim folhas apadrinhadas por ele, dedicadas a campanhas políticas.

${ }^{66}$ ACD, sessão de 8/6/1847, pg. 288.
} 
inovar, nem rescindir um contrato sustentado e cumprido há tanto tempo a contento de todos. Sr. Presidente, o que nós devemos querer e a casa, o que convém ao público, é que nossos trabalhos, que tudo quanto aqui se passa, seja publicado com a maior exatidão. (...) Sr. Presidente, eu entendia que um dos grandes empenhos que os homens de Estado do nosso país deveriam ter era o de descobrir o meio de bem dirigir, e de bem formar, a opinião pública; isto creio que não é negócio indiferente, é matéria importantíssima",67.

Realmente, não parece acertado que, depois de tantas negativas, a Câmara se motivasse a rescindir o contrato com o Jornal do Commercio. A 'razão muito forte', talvez ilegítima aos olhos de muitos deputados, era realmente o poder de barganha conferido pelo governo ao jornal. Na fala do deputado, evidencia-se também uma concepção que considera a formação da opinião pública uma tarefa pedagógica que o Estado deve tomar a si, pois, do contrário, outros o farão, e contra ele. Dessa forma, não se deveria mudar um contrato que vinha publicando os trabalhos parlamentares satisfatoriamente, fazendo chegar aos cidadãos as opiniões de seus representantes, instruindo-os nos benefícios do governo constitucional.

O magistrado pernambucano Urbano Sabino Pessoa de Melo também critica o parecer da mesa:

“A Gazeta Oficial é folha do governo; não há ali nada que contratar: se acaso a câmara dos srs. Deputados quiser publicar oficialmente os seus trabalhos na gazeta do governo (...), é adotar uma medida que isto determine. A câmara não tem que contratar: é decretar que seus trabalhos sejam publicados nessa folha" 68 .

O deputado lembra que o poder legislativo poderia obrigar o governo a publicar, até mesmo gratuitamente, seus trabalhos nos jornais sob sua responsabilidade. E por que não o fazia? Essa questão não foi levantada, mas pode-se imaginar que o deputado fosse outro a pensar nos problemas que um jornal do governo poderia causar à Câmara, especialmente quando os dois poderes estivessem em conflito. Além disso, Urbano lembra que o Jornal do Commercio poderia desinteressar-se pela publicação durante a experiência, pois "o interesse é o privilégio da publicação": uma vez que o subsídio era

\footnotetext{
${ }^{67}$ ACD, 22/6/1847, pg. 429-430.

${ }^{68}$ ACD, 23/6/1847, pg. 435.
} 
todo consumido pelos custos da publicação, o verdadeiro lucro para a folha consistia em ser a única a dispor os trabalhos para os interessados ${ }^{69}$.

Como no caso dos debates sobre a Tipografia Nacional, nessa discussão se levanta o argumento do apoio à empresa nacional. Joaquim Francisco Muniz Barreto, o $1^{\circ}$ secretário, defende o parecer nessas bases:

"Eu já ontem disse que a empresa do Jornal do Commercio é digna de todos os elogios (...), não há motivos para que não seja amparada; mas que esse amparo chegue ao ponto de não auxiliarmos qualquer empresa nacional, é no que não posso convir",70.

O fato de a Gazeta Oficial ser uma folha do governo lhe rendia apoio entre os deputados governistas, mas ao mesmo tempo mobilizava aqueles que não viam com bons olhos nem a administração estatal de empresas nem a possível manipulação que os discursos da oposição poderiam sofrer ao serem editados por funcionários públicos. $\mathrm{O}$ baiano Ângelo Muniz da Silva Ferraz é um dos que argumenta nesse sentido:

"Sr. Presidente, o nobre deputado ainda fundou seu argumento na preferência que deve ter uma empresa dirigida pelo governo. Todas as empresas dirigidas pelo governo são más, não apresentam resultado profícuo, o governo é o pior administrador a respeito de empresas e estabelecimentos de indústrias (...). Quererá a câmara por ventura que a leitura dos discursos de seus membros fique restrita a um certo e limitado número de leitores? Na expedição desta folha, o governo não poderá lançar mão de tropeços para que os discursos de certos deputados não corram, para que sejam demorados? Qual a garantia que oferece o nobre deputado à minoria que está em hostilidade com as idéias do governo?"71.

O 'número restrito e certo' de leitores certamente é o daqueles que liam o periódico governista, audiência - segundo o deputado - menor do que a do Jornal do Commercio, ainda que este também nunca tenha assumido qualquer oposição relevante ao governo.

\footnotetext{
${ }^{69}$ ACD, idem, ibidem.

${ }^{70}$ ACD, idem, página 436.

${ }^{71}$ ACD, idem, página 436-437.
} 
A discussão continua com José de Barros Pimentel, deputado por Sergipe, reforçando os argumentos do $1^{\mathrm{o}}$ secretário:

"Animemos uma empresa nacional, uma empresa que faz orgulho a quem a criou, porque era indigno de um país livre, de um país monárquico representativo, que não houvesse uma Gazeta de onde partissem todos os atos dos diferentes poderes do Estado; e agora que está criada, agora que ela pede o auxílio dos diferentes ramos da pública administração, seremos nós que lhe iremos negar esse auxílio?",72.

O mais interessante, no entanto, é que, em certo momento, o deputado convertese em procurador da Gazeta Oficial e afirma se achar habilitado para "oferecer uma emenda, por parte da administração da folha, para fazer por quase metade do custo a publicação dos debates da casa"73. Tanta concorrência pela publicação dos debates, que inclusive fazia baixar o preço exigido da câmara, faz pensar que a transcrição das sessões realmente interessava aos leitores, ou mesmo conferia algum prestígio ao jornal que o fizesse.

No dia 3 de julho, João Maurício Wanderley, representante da Bahia, defende a mudança no contrato como tentativa de compromisso entre as partes: nem os discursos, uma vez corrigidos pelos oradores, seriam alterados, nem o governo se utilizaria da folha em prejuízo da oposição. Lembra, ainda, que a circulação do Jornal do Commercio era limitada, as províncias não o liam, e assim "o corpo eleitoral não conhece as opiniões que aqui se emitem (...) [ou] só se limita a um pequeno círculo e a políticos mais interessados"74. Até então, o argumento da ampla distribuição pelo país era usado a favor do Jornal, mas isso não é questionado, como também não se fazem outras afirmações a respeito do alcance da Gazeta. De qualquer forma, está presente a preocupação de informar aos eleitores o comportamento dos deputados a fim de se guiarem nas próximas eleições.

Finalmente, o paulista José Antônio Pimenta Bueno relembra que a questão tem um lado político e outro econômico, e que a mesa, dando atenção ao segundo, esqueceu do mais relevante; retoma então o perigo da manipulação dos discursos:

\footnotetext{
${ }^{72}$ ACD, idem, página 451.

${ }^{73}$ ACD, idem, pg. 451.

${ }^{74}$ ACD, 3/7/1847, páginas 34-35.
} 
“Direi, sr. Presidente, em relação a questão política, que os membros desta casa, qualquer que seja o partido, têm direito de emitir a sua opinião e de vê-la reproduzida perante o país; que esse direito não só deve ser exercido com toda a independência do governo em sua publicidade, mas que deve haver plena consciência dessa liberdade. Creio que é um princípio filho da natureza e da índole do sistema representativo. (...) Não pode haver abuso na entrega de nossos trabalhos à ação ministerial? Pode haver; basta essa suspeita para que não se adote o parecer (...). Além disso, pergunto: não é natural que se pense que o editor da Gazeta Oficial, seja mais afeiçoado ao governo, que reproduza com mais gosto os discursos dos membros desta casa que apoiarem a administração?"75.

Como em nenhum outro caso, é muito forte a questão da orientação governista da folha - especialmente porque também é inédito o grau de desinteresse financeiro do jornal. Os outros pretendentes à remuneração ofereciam pequenos descontos em relação ao preço cobrado pelo Jornal do Commercio, enquanto a Gazeta, por meio de seu 'representante' Barros Pimentel, ofereceu seus serviços por um valor que provavelmente não cobria os gastos advindos da obrigação. Se pretendia abrir mão de parte dos lucros com a venda de exemplares, teria outra fonte de renda que compensasse essa perda - talvez um subsídio governamental. Pode ser que o prestígio de ser o jornal contratado pela Câmara, ou a possibilidade de controlar a publicização de certos discursos, fosse suficiente para compensar a perda econômica. Não é possível precisar aqui quais seriam suas motivações, mas o episódio é bastante revelador das possibilidades econômicas abertas pelas idéias e práticas políticas liberais: diferentes estruturas de poder criam novas elites, que se relacionam por outros tipos de lealdade e meios de gratificação. Não é razoável supor que a importância atribuída pelos deputados à publicação de seus trabalhos fosse apenas um subterfúgio a lhes permitir distribuir dinheiro público em forma de subsídios à atividade; e, por mais politizada que fosse esta questão (apenas aparentemente técnica, a melhor qualidade do serviço deveria ser beneficiada pelo contrato), ela estava sendo submetida a uma negociação que dificultava o predomínio de interesses meramente pessoais, por ter de angariar apoio entre diversos interesses.

${ }^{75}$ ACD, 5/7/1847, pg. 41-42. 
No dia seguinte, 6 de julho, procede-se à votação, e o parecer da mesa não é aprovado, o que significaria, em tese, o não acatamento da proposta e, conseqüentemente, a manutenção do contrato com o Jornal do Commércio. No entanto, dúvidas e reclamações posteriores dão a entender que o contrato foi suspenso, ficando a Câmara novamente sem uma empresa que lhe prestasse o serviço regularmente.

A primeira menção à falta de publicação satisfatória dos trabalhos surge no ano seguinte, quando Nunes Machado pergunta à mesa sobre o negócio da publicação dos debates:

"A câmara se compenetrará da importância de serem os nossos trabalhos publicados em toda sua extensão, é esta uma das primeiras condições do sistema representativo (...). Bem que o Jornal do Commercio tenha apresentado até hoje em resumo os trabalhos com a maior exatidão possível, contudo este modo de publicar os debates da câmara não pode satisfazer as necessidades públicas. Se a mesa encontra obstáculos por falta de empresários ou de taquígrafos, ou por falta de meios pecuniários, estou resolvido pela minha parte a propor o maior sacrifício possível para se conseguir por extenso a publicação dos nossos trabalhos"

Pelo relato, vê-se que apesar do rompimento do contrato o Jornal do Commercio continuara a publicar as sessões, agora resumidas, o que também qualifica a hipótese de que os trabalhos parlamentares tinham de fato interesse para os seus leitores, sugerindo que o alcance das discussões era bastante amplificado pelo Rio de Janeiro e outras províncias, uma vez que o Jornal era o que contava com uma das melhores distribuições pelo país.

O $1^{\circ}$ secretário responde que a mesa recebeu propostas verbais da direção do Diário do Rio e do Correio Mercantil, que deveriam apresentá-las por escrito. Não há mais informações ou discussões sobre o assunto, mas em julho surge uma indicação de um representante do Rio Grande do Sul, Pedro Rodrigues Fernandes Chaves, para que se rescinda o contrato de publicação dos trabalhos com o Correio Mercantil. Adiada a discussão para uma ocasião oportuna, não consta, porém, ter retornado à pauta ${ }^{77}$.

\footnotetext{
${ }^{76}$ ACD, 15/5/1848, pg. 75.

${ }^{77}$ ACD, 28/7/1848, pg. 128.
} 
É só em janeiro de 1850 que o assunto volta à agenda da câmara, novamente com uma proposta do Jornal do Commercio, apresentada à Câmara no dia 3. A novidade da discussão, na qual se repete o entendimento da função da publicidade no sistema representativo $^{78}$, é a preocupação manifesta por alguns deputados com o monopólio exercido pelo Jornal, como o faz Joaquim José Pacheco, deputado por São Paulo:

“(...) será difícil que a publicação dos debates não seja confiada ao Jornal do Commercio, pela razão apresentada pelo nobre deputado por São Paulo, de que esta folha é sem dúvida a que até o presente tem desempenhado melhor semelhante publicação; e além disso, é sabido que é o jornal mais lido, que mais circulação tem no império; porém é necessário, Sr. Presidente, que quando tratarmos desse objeto não deixemos que se abuse desse quase monopólio em que se acha o Jornal do Commercio; é necessário que procuremos melhorar, que não fiquemos no mesmo terreno"79.

No dia 29 entra em discussão o parecer da mesa, que aprovava a proposta. O deputado gaúcho José Martins da Cruz Jobim relembra a necessidade de fortalecer outras folhas face à importância crescente do Jornal do Commercio, argumentando que sua força perante a opinião pública poderia eventualmente se virar contra os interesses do Estado:

“quando não nos é dado calcular quais são as perturbações políticas que ele
com essa imensa força de atração pode produzir no nosso país, tenho grandes
receios da importância crescente que vai todos os dias tomando este periódico,
mormente no caso de nos vermos a braços, por exemplo, com qualquer nação
estrangeira. Nós sabemos que um jornal desta ordem é ordinariamente quem
forma a opinião de um país; sabemos bem qual é o conceito que em geral os
homens de senso devem fazer do que se chama opinião pública, ordinariamente
formada pelos jornais, sobretudo da natureza deste, tão lido, tão apreciado por
todos. Ordinariamente a reflexão não é partilha das massas, elas aceitam as

\footnotetext{
${ }^{78}$ Nas palavras do paulista José Inácio Silveira da Motta: "No governo representativo em que vivemos, no governo da responsabilidade não só dos atos mas ainda das opiniões e princípios dos homens que aparecem no país à testa dos negócios públicos, é essencial, para que se possa verificar a responsabilidade das opiniões e dos princípios, que haja meios seguros, exatos, pelos quais se reconheça quais são essas opiniões (...)” (ACD, 4/1/1850, página 93).

${ }^{79}$ ACD, 4/1/1850, pg. 94.
} 
idéias que se lhes apresentam, e em um papel como este pode-se muito bem de um modo sutil incutir nos sentimentos da população idéias muito contrárias àquelas que são realmente úteis e proveitosas para o país (...). Portanto, Sr. Presidente, (...) é necessário que o quanto antes estabeleçamos um contrapeso à influência extraordinária que o Jornal do Commercio todos os dias adquire no país" ${ }^{\prime 80}$.

A grande circulação da folha não é mais um benefício à divulgação das opiniões dos deputados, mas sim uma possível ameaça ao governo num eventual conflito com outros países, pois era possível que o jornal se dedicasse a convencer a opinião pública da razão dos inimigos - isso porque seus proprietários não eram brasileiros e sim franceses. O argumento da necessidade de promover a empresa nacional surge novamente, com uma roupagem inédita, a da segurança nacional. Mas, mesmo em situação de paz, o jornal poderia trabalhar as idéias do povo, tão desajuizado e impulsivo, no sentido de destruir as bases necessárias para o progresso nacional. Certamente o deputado passara por algum desagravo com o jornal, para imaginar-lhe interessado em tais maquinações. A sugestão de Jobim é que a nação tenha um jornal próprio, impresso na Tipografia Nacional, incumbido de publicar os atos do governo, tanto central como provincial.

Os receios de Jobim não são ecoados por outros deputados, que vêem no periódico a única maneira de publicar satisfatoriamente os trabalhos da Câmara: já iam adiantados nessa sessão, não podendo aguardar muito mais tempo. O contrato é aprovado na sessão do dia 30 de janeiro, e novamente a folha passa a ser a responsável pela publicação dos debates. A partir de então, é comum encontrar, no início das sessões, reclamações e pedidos de retificação de discursos e apartes errados, como parte do acordado entre a Câmara e o periódico. Até 1855 essa situação permanece inalterada.

A partir dessa exposição, é possível concluir que a publicidade dos atos legislativos, seja por seu potencial pedagógico e civilizador, seja pela necessidade de informar ao público os trabalhos e opiniões de seus representantes com vistas às próximas eleições, foi uma preocupação constante da Câmara dos Deputados. Não lhes escapou sua essencialidade para a configuração do sistema representativo, que, enquanto governo da razão e da opinião pública, só se legitimaria a partir da divulgação

${ }^{80}$ ACD, 29/1/1850, pg. 350. 
e discussão de seus atos, e posterior aprovação ou reproche via expressões da opinião, como o voto ou a imprensa.

A publicidade dos trabalhos da Câmara, assim como a liberdade de imprensa, era uma questão doutrinária e política, de ordem prática e, como não poderia deixar de ser, a concretização desses postulados teóricos não foi simples: movimentando interesses e receios diversos, criou tensões na Câmara, obrigada a negociar entre seus integrantes os critérios razoáveis para a escolha, primeiro, entre um empreendimento próprio ou a terceirização. Uma vez escolhida a segunda, a maior dificuldade foi a de contratar com um jornal capaz de angariar uma mínima confiança entre parlamentares governistas e da oposição. Esse tipo de equilíbrio é difícil de ser mantido e, como se viu, as discussões sobre o posicionamento político da folha contratada e a parcialidade de suas transcrições foi motivo de grandes disputas.

Por outro lado, deve-se atentar à comunicação que se estabelece entre a Câmara e a sociedade na medida em que aquela passa a se relacionar direta e financeiramente com os veículos de comunicação. Apesar de o apadrinhamento político de jornais (pelo governo) estar sempre presente nas discussões parlamentares, não há considerações sobre a influência que o contrato entre ambos pode exercer na linha editorial do periódico. Tampouco ocorreu aos deputados estabelecer exigências em relação ao conteúdo a ser veiculado por seu contratado (ou seja, uma tentativa direta de ingerência); ao contrário, a preocupação era sempre de que a orientação política da folha interferisse na qualidade da apresentação dos discursos, pendendo para um ou outro lado de determinada questão, ou mesmo prejudicando os deputados que fossem contrários às posições defendidas pelo jornal.

Por fim, vale lembrar que a publicação dos Diários da Câmara cumpria a importante função de demarcar a extensão de seus poderes, sancionando sua legitimidade e autoridade e atestando-as para todo o país. Ao registrar seus trabalhos, os parlamentares gravavam também suas próprias imagens na história do país e, mesmo que involuntariamente, erigiam um 'monumento' 81 ao parlamentarismo monárquico brasileiro.

\footnotetext{
${ }^{81}$ Jacques Le Goff, op. cit.
} 


\section{Capítulo 5}

\section{A imprensa e o Parlamento}

Este capítulo analisará maneiras pelas quais os redatores de alguns periódicos buscaram influir nas políticas públicas discutidas pelos deputados. No entanto, o objetivo não é fazer aqui uma análise aprofundada, pois a amostra documental colhida não é significativa; o que se pretende é apresentar este pequeno apanhado, de modo a demonstrar como as concepções defendidas pela imprensa não divergiam muito do que era debatido na Câmara, especialmente no que diz respeito à liberdade de imprensa. Isso porque, como já se disse, a atividade política dos jornais é amplamente explorada pela historiografia, sendo consenso de que eram um espaço privilegiado e fundamental para a circulação de idéias e projetos para o país.

Os jornais escolhidos foram o Jornal do Commercio, a Aurora Fluminense e o Diário de Pernambuco. Os dois primeiros eram publicados na Corte e tinham grande prestígio no meio editorial, por sua importância política. Já foram apontadas, em outros capítulos, suas orientações políticas: o Jornal alinhava-se com o poder executivo, e a Aurora era redigida pelo deputado Evaristo da Veiga, importante liberal moderado, sendo assim um órgão de oposição ao governo, amplificador da oposição exercida na Câmara. O Diário de Pernambuco, editado em Recife, era o jornal mais importante da província, longevo e de periodicidade constante. A historiografia da imprensa brasileira normalmente classifica o Diário de Pernambuco como uma folha conservadora, semelhante ao Jornal do Commercio. O que a pesquisa dos primeiros anos de publicação de ambos revela, no entanto, é que dificilmente podem ser encaixados na mesma categoria, pois o Diário normalmente criticava a administração central e elogiava a atuação da Câmara dos Deputados, além de reproduzir constantemente artigos de jornais liberais moderados, como a Aurora Fluminense e o Universal, um reflexo da oposição das províncias ao regime centralizado de D. Pedro I.

A primeira forma de atuação política dos redatores a ser explorada aqui é a interlocução que estabeleciam com a Câmara dos Deputados, ou mesmo com as assembléias provinciais e municipais. Inicialmente, vale lembrar que eram muito comuns textos recomendando aos representantes um ou outro encaminhamento para uma questão em voga. Entre as funções atribuídas à imprensa, estavam a de reivindicar aos governantes soluções para os problemas locais ou nacionais e a de orientá-los sobre 
o estado da opinião geral, a fim de informar seus cálculos políticos e decisões. O clamor da opinião pública poderia funcionar, no fim das contas, como agente de pressão (contra ou a favor) em determinados assuntos.

É claro que não se pode levar a sério a pretensão de universalidade do discurso dos redatores - quando muito, falavam em nome de grupos que compartilhavam de seus interesses. Esta é justamente uma das características mais marcantes da mobilização política do conceito de opinião pública: a capacidade de trabalhar interesses restritos a determinados grupos de maneira a estendê-los a toda uma comunidade ou nação. ${ }^{1}$ Como sugere Bernard Manin, a opinião pública deve ser entendida como a opinião de uma parcela da população que, organizada (em torno de partidos, clubes, jornais), consegue reunir forças que antes se encontravam dispersas e amplificar o alcance de suas demandas $^{2}$.

Nesse sentido, o Jornal do Commercio, no dia 27/2/1836, por exemplo, publica suas opiniões sobre aqueles que considera os assuntos mais urgentes a serem tratados pela assembléia da província do Rio de Janeiro: o melhoramento dos transportes, a administração da justiça e a instrução pública, aproveitando para criticar a extinção da vila de Iguaçu. Em 28/7/1832, encaminha pedido para que a câmara considerasse seriamente a criação de um presidente de província para o Rio de Janeiro, chamando nominalmente o deputado pela capital Castro Álvares a "dar um impulso a esse negócio com o que ganharia as bênçãos de seus constituintes, que esperam não ter de se arrepender de tão boa escolha". O jornal claramente cobra do deputado que encaminhe tal reivindicação, e o ameaça com a possível perda de credibilidade junto aos seus eleitores, o que, numa próxima eleição, poderia também colocar sua continuidade no cargo em risco.

Esse mesmo jornal manteve uma tradição intermitente (enquanto não remunerada diretamente) de publicar extratos dos debates da Câmara dos Deputados (em especial), do Senado, da assembléia provincial e até mesmo de algumas reuniões do corpo de jurados. Como se viu, a preocupação com a publicidade dos trabalhos legislativos sempre foi muito grande, pois a transparência dos atos governamentais era fundamental para o sistema representativo: disso dependia a formação da opinião pública e a informação dos constituintes a respeito da atuação de seus representantes.

\footnotetext{
${ }^{1} \mathrm{O}$ mesmo efeito é produzido por outras expressões que também sugerem apoio geral inequívoco, como é o caso de "interesse nacional".

${ }^{2}$ Bernard Manin. Los principios del gobierno representativo. Madrid: Alianza Editorial, pg. 211.
} 
De maneira semelhante, a Aurora Fluminense de 2/5/1828 comemora a abertura da sessão legislativa da Câmara dos Deputados e lista como trabalhos mais urgentes a criação dos códigos civil e criminal, a reforma das finanças públicas, a regulamentação dos corpos de jurados e a direção da indústria e instrução pública nacionais. No mesmo exemplar, ainda cobra empenho dos deputados na publicação dos trabalhos da casa, que andava muito atrasada e deficiente, e "toma a ousadia" de lembrá-los de levar em consideração um projeto de Odorico Mendes, sobre a extinção dos morgados, e outro de Miranda Ribeiro, para o estabelecimento de júris. No dia 16 de junho do mesmo ano, nota uma falha a ser reparada pela câmara no projeto de resolução das eleições e sugere a sua emenda.

O expediente de dirigir-se aos representantes também era praticado pelo Diário de Pernambuco. Em 15/1/1830, é publicado um artigo que recomendava à Câmara Municipal de Recife a aprovação do projeto que previa a construção de um celeiro público na cidade, apresentado pelo conselheiro Antunes.

Esse tipo de contato entre redatores e representantes é abundante, e outros exemplos poderiam preencher toda uma monografia. Uma outra atividade a que se dedicaram os periódicos foram as avaliações do comportamento e da atuação dos políticos, e são essas que visavam realmente convencer seus leitores de determinado ponto de vista, sendo tal abordagem a que mais deixava transparecer a orientação do jornal.

O Diário de Pernambuco, reproduzindo um artigo da Aurora Fluminense, por exemplo, manifesta-se contra a distribuição indiscriminada de comendas e títulos imperiais, motivado pela verificação de que alguns deputados foram agraciados com as comendas de Cristo e de Aviz. Questionando o merecimento, entra no juízo dos méritos dos contemplados:

"Perguntamos a nós mesmos, mas debalde, o que se poderia achar nestes srs., que os tornasse dignos de um sinal de distinção honorífica, e queríamos que eles próprios fossem juízes nesta causa, e nos dissessem a que título, por que notabilidade se constituíram merecedores de uma graça que os indica como aqueles que melhor aprouveram aos desígnios e vontade do poder. Se excetuarmos o sr. Ledo, que contudo poucas vezes orou, e Deus sabe em que sentido, todos os outros (fossem quais fossem suas qualidades e capacidade intelectual) conservaram na câmara quase perpétuo silêncio, e não consta que nas comissões, ou por qualquer outro meio, eles se elevassem acima da mais 
obscura mediocridade (...). Que pode haver verbi gratia em um Domingos Malachias, que o torne digno de ocupar a linha entre os agraciados de um governo, que quer a felicidade pública? Marcado com o ferrete da abjeção, cortesão aviltado de todos os ministros, de todas as veleidades ministeriais, serão esses os títulos que o habilitarão para obter a comenda de Cristo?"”3

A atribuição de honras a deputados que não cumprem o dever de debater e expor suas opiniões no parlamento, e mais ainda àqueles conhecidos por sua cumplicidade a ministérios corruptos, colocava sob suspeita o governo e seu comprometimento com o sistema constitucional (que uma manobra linguística transforma na "felicidade pública").

Continuando na linha dos artigos que se posicionam contra os "servis" que lutavam contra a liberdade constitucional, é interessante uma passagem da Aurora Fluminense:

"Não podemos deixar de render os nossos mais respeitosos, e sinceros agradecimentos aos ilustres varões, que no augusto recinto da Câmara dos srs. Deputados fizeram ver a inépcia de tal Ministério, e o mal, que dele resultava ao Brasil (...). Continuai, pois, ilustres campeões da liberdade a esmagar a hidra do despotismo...."

O moderado Evaristo da Veiga, redator da Aurora Fluminense e deputado geral, homenageia aqui seus colegas que, como ele, dedicam-se no plenário a combater as políticas do ministério de José Clemente Pereira, considerado absolutista por defender maiores poderes ao imperador - de maneira geral, ao poder executivo - e também por tomar para si competências exclusivas da câmara. Esse expediente também não passou sem nota pela Aurora: no dia 5 de abril do mesmo ano, o jornal censura rispidamente o comportamento das tropas irlandesas, que vinham causando diversos tumultos nas ruas do Rio de Janeiro, e reclama que seu recrutamento não havia sido ordenado pelo parlamento - o que estava entre suas atribuições -, mas sim diretamente pelo imperador.

A ênfase do Jornal do Commercio é distinta, normalmente veiculando avaliações negativas sobre o trabalho da câmara. Em 15/10/1828, o jornal critica o parlamento que, mesmo "com um ministério quase todo saído de si”, não cumpriu a missão de criar "uma organização financeira regular, e baseada no crédito, e um sistema judiciário baseado no princípio da publicidade dos debates, e excelência do júri”, o que

\footnotetext{
${ }^{3}$ Diário de Pernambuco, 2/12/1829.

${ }^{4}$ Aurora Fluminense, 11/2/1828.
} 
fez com que a terceira sessão passasse sem nenhum resultado concreto. No ano seguinte, no dia 20/10/1829, ao comentar a necessidade de códigos especiais para o direito nacional, afirma que as câmaras não tinham tempo para elaborá-los, e prefere confiar essa tarefa a comissões formadas pelo governo (ministérios); depois de concluída, passaria pelo crivo do público e do parlamento.

Críticas e elogios são maneiras de trazer os assuntos do governo à discussão pública, assim como o desempenho dos representantes na sua condução. O fato de ser pela imprensa que se encaminhavam as reivindicações do que se julgava necessário e as análises do que estava sendo feito mostra sua importância para a movimentação política da época, assim como evidencia a percepção da existência de uma opinião pública a ser conquistada, conduzida ou informada pela oratória dos jornalistas. Novamente, não se trata aqui de uma opinião generalizada e uniforme a respeito de um tema, mas sobretudo a opinião de indivíduos expressando publicamente suas visões de maneira a convencer sociedade e governo de que esse julgamento não diz respeito somente aos seus interesses privados. ${ }^{5}$

Por esse motivo, vale destacar a militância dos jornais em tempos de eleição. Como participantes ativos, eles se preocuparam em promover e minar candidaturas, além de orientar os eleitores quanto às qualidades que os candidatos deveriam ter para melhor cumprir suas obrigações.

É nesse último ponto, finalmente, que a Aurora Fluminense e o Jornal do Commercio aproximam-se. Em 27/6/1828, motivada pela indignação contra os deputados que se mantinham calados durante as sessões, a Aurora pede maior cuidado aos eleitores na hora de escolher seus candidatos e aconselhava preferência aos

"proprietários, os advogados, todos os cidadãos enfim, que seguem um gênero de vida independente, são muito mais aptos, para defenderem os direitos e os interesses do povo; a voz do empregado público seca, e pára muitas vezes na garganta, quando lhe lembra que é criatura do poder, e que do poder depende ou o seu adiantamento, e pingues cargos, ou preterições, e inteira nulidade."

O Jornal do Commercio faz observação semelhante ao censurar a mudança de orientação, a respeito da reforma constitucional, de um deputado já eleito, José Cesário de Miranda Ribeiro, autor do projeto que resultaria no Ato Adicional:

\footnotetext{
${ }^{5}$ Esse é o traço definidor da "esfera pública burguesa", segundo Habermas: a discussão dos assuntos do governo se faz por meio da aglutinação de pessoas privadas em forma de público.
} 
"De tudo isto se deduz a grande necessidade que tem a nação de estudar com muita sisudeza e cuidado na escolha dos seus representantes para a nova legislatura (...). Proprietários principalmente, homens de letras, probidade e reconhecida experiência das coisas públicas, eis aqui os verdadeiros representantes da nação."6

Para as duas folhas, a classe dos proprietários deveria ser privilegiada pelos cidadãos, pois a independência financeira advinda desse status era boa garantia contra a corrupção dos representantes. A segunda categoria recomendada era a dos profissionais liberais ou homens de letras, o que, no século XIX, remetia diretamente aos bacharéis, especialmente os de Direito. A formação superior garantia, no seu entender, conhecimento dos processos políticos mais amplos e, como consequiência, maior zelo pelos interesses gerais - outro tipo de proteção contra o aliciamento financeiro, além de sinalizar alguma fineza do trato. Por outro lado, aqueles que tiravam seu sustento dos serviços burocráticos do Estado, como os funcionários públicos, deveriam ter seus méritos analisados com cautela, pois a priori seus meios de vida dependiam do governo, o que lhes subtraía grande parte de sua autonomia, comprometendo sua atuação legislativa. A ênfase na importância da renda, propriedade e saber na escolha dos legisladores também foi o fundamento da adoção, na Constituição de 1824, de critérios censitários para o voto e a candidatura como modo de garantir uma "boa representação", consoante com a maneira de seleção prevalecente nos demais regimes representativos ocidentais da época. Para tais regimes, a exclusão de boa parte da população era uma virtude, pois impedia a participação de setores pouco esclarecidos ou dependentes de poderes locais na eleição dos governantes. Esses são traços do pensamento de Benjamin Constant e François Guizot, que consideravam as eleições o melhor método de seleção não tanto por permitir a participação de um maior número de pessoas na escolha dos governantes, mas por permitir selecionar entre os cidadãos aqueles mais preparados para assumir as funções públicas. Nas ótimas palavras de Manoel Hespanha, quando se pensava no 'governo dos melhores',

"Já não se trata[va] de efectuar uma aritmética complexa dos interesses e das vontades, mas de "de recolher, concentrar toda a razão que existe dispersa na sociedade", de "extrair da sociedade tudo o que ela possui de razão, de justiça, de verdade, para o aplicar ao seu governo",7.

\footnotetext{
${ }^{6}$ Jornal do Commercio, 06/09/1832.

${ }^{7}$ Antonio Manoel Hespanha, op. cit, página 107.
} 
A campanha eleitoral propriamente dita também tinha seu espaço nos jornais. Foram encontradas diversas listas de candidatos recomendados por cada periódico. A título de ilustração, cabe a que a Aurora Fluminense publicou no dia 30/7/1828: Major Antônio José do Amaral (diploma superior); Padre Antônio João de Lessa (diplomado e fazendeiro); Aureliano de Souza e Oliveira (juiz de fora); Antônio Pereira Barreto Pedroso ("moço magistrado"); Francisco Gomes de Campos (proprietário, funcionário público, “de instrução"); João Mendes Vianna (proprietário); Francisco Antônio Leite e Manoel Teixeira da Costa (negociantes); Antônio Pereira Pinto (fazendeiro); e Cândido Baptista de Oliveira (lente da Academia Militar). As profissões dos indicados estão entre aquelas tidas por confiáveis para lidar com o poder, e o único funcionário público a figurar na lista é também proprietário e "de instrução", preenchendo assim outros requisitos fundamentais para uma atuação virtuosa, segundo as concepções liberais vigentes.

Quando foi criticada pelo jornal Constitucional Rio Grandense (publicado em Porto Alegre), por fazer campanha aberta para o candidato Cândido Baptista de Oliveira, ${ }^{8}$ a Aurora de 20/10/1828 assim justificou seu procedimento: "A proposição franca do candidato (...) oferece um meio para se discutir a capacidade, ou incapacidade do sujeito, e institui uma polêmica muito necessária para se efetuarem dignas escolhas". Como se vê, a indicação dos candidatos era vista como um meio para discutir publicamente as atribuições de cada um e de todos. E é claro que também havia interesse em conquistar aqueles eleitores mais distanciados da política e menos interessados nela, que se deixassem levar pelas sugestões de seu jornal favorito. ${ }^{9}$

Do lado oposto, a estratégia encontrada nos jornais analisados para minar candidaturas se baseava principalmente no relato de mudança da orientação política pela qual um candidato havia anteriormente sido eleito, como se tal atitude configurasse uma traição para com seus constituintes, que votaram em um programa e veriam outro ser defendido. Isso é exemplificado pela matéria publicada no Jornal do Commercio de 6/9/1832, citada acima, que denuncia a viravolta de José Cesário de Miranda Ribeiro, e também pela lembrança da Aurora, de 18/4/1828, que deseja que os eleitores não se arrependam pela escolha de Lúcio Soares Teixeira de Gouvêia para deputado, apesar de

\footnotetext{
${ }^{8}$ Os termos do jornal foram os seguintes: "[a folha gaúcha] acha tedioso, e cheirando a suborno inculcar a qualquer para Deputado por meio de uma folha pública." Grifos meus.

${ }^{9}$ E não era somente para os eleitores que os jornais dirigiam suas campanhas: a Aurora de 18/4/1828 publica grande "torcida" para a nomeação, pelo imperador, de Nicolau Vergueiro para senador da província de São Paulo, seguida de grande elogio das qualidades do até então deputado paulista.
} 
sua saída da oposição para o campo áulico. Não foram encontradas, no entanto, menções que buscassem denegrir candidatos que ainda não tivessem ocupado nenhuma cadeira no governo ou no legislativo; para esses, ser deixado de lado num momento em que a publicidade era fundamental parece ser suficientemente nocivo.

Esta breve exposição fornece indícios de que a imprensa do período era ferramenta fundamental para a política cotidiana, por dirigir-se a um público maior do que aquele freqüentador dos tradicionais espaços políticos, e também por se propor a convencê-lo a sustentar nas urnas as opiniões ali defendidas.

Além de questões políticas mais concretas e imediatas, os periódicos engajaramse também em discussões sobre as premissas do governo constitucional. Os textos privilegiados aqui dizem respeito à liberdade de expressão do pensamento.

Os jornais trataram da liberdade de imprensa de diversas maneiras. Inicialmente, é interessante explorar as defesas de princípio, que se escoram na sua essencialidade para o florescimento do sistema constitucional representativo, ilustradas pelo seguinte trecho extraído da Aurora Fluminense:

"Liberdade de imprensa é sem dúvida a arma mais poderosa para destruir os planos dos inimigos do Estado, o remédio mais eficaz para sanar antigas enfermidades na Administração da Justiça (...). Como se pode aumentar a instrução pública sem um livre canal, por onde ela se espalhe? Como pode ser patente a inobservância da lei com a coibição da imprensa? (...) Em uma palavra, o menor passo dado para o mais leve ataque da liberdade de imprensa, no instante, em que ela sofrer o mínimo toque das mãos de seus rusguentos inimigos, contai com a vinda de um próximo choque nos Negócios do Estado."10 (grifo meu).

Essa passagem informa duas idéias diferentes a respeito das funções atribuídas à atividade periodística por Evaristo da Veiga. A primeira é a de salvaguardar o Estado dos ataques de seus inimigos, provavelmente por meio da instrução do povo a respeito dos benefícios da estrutura institucional adotada e do conhecimento da atuação governamental a seu favor; a outra, fiscalizar a aplicação das leis e denunciar seu descumprimento. A coibição do jornalismo, portanto, facilitaria a subversão dos negócios do governo, já que lhe proporcionaria um tratamento obscuro, assim como a predominância de interesses privados.

${ }^{10}$ Aurora Fluminense, 4/1/1828. 
Outro bom exemplo desse enfoque é do Diário de Pernambuco:

“Todas as verdades são úteis ao público, e a sua disseminação é sempre uma vantagem, exceto quando injuriam. Dizer o contrário é o mesmo que sustentar que as trevas são a luz, e que o não-senso (sic) é razão. Contra isto às vezes o poder condescendia fazer-nos certas confidências sobre os perigos desta liberdade, mas os seus receios não menos descobrem a sua má-fé, do que a insuficiência de suas precauções (...). Não há portanto no poder interesse algum em cativar os pensamentos senão quando ele quer arbitrariamente dispor das pessoas, dos bens e da indústria" ${ }^{\prime 1}$

Do trecho, depreende-se a idéia de que qualquer tentativa de um governo de limitar a liberdade de expressão trabalharia no sentido de podar a racionalidade, pressuposto de uma legislação aplicada igualmente para todos e criada para isso, de sua administração, a fim de promover distinções e privilégios - que eram, como é sabido, profundamente odiados e combatidos pelos liberais oitocentistas.

No ano seguinte, o mesmo jornal, questionando doutrina publicada nas folhas de seu rival absolutista, o periódico Amigo do Povo, questiona nas mesmas bases a censura prévia dos escritos:

"Nós vamos defender contra as subversivas doutrinas do Amigo do Povo, a utilidade e o direito da liberdade de imprensa (...). Ser a liberdade de imprensa o santelmo, e o luzeiro de um sistema constitucional, e ser a base mais sólida de um governo livre, está já decidido: e basta um artigo de nossa Constituição. (...) Mas querer reprimir pela censura o uso da imprensa, só porque dela se pode abusar, então bem poucas coisas nos seriam permitidas, pois até da religião se abusa (...). E porque podem nos resultar alguns danos, devemos privar-nos de todos os bens e, ainda mais, aos inapreciáveis benefícios que podem resultar? (...) Nada tem tanto aviltado a humanidade como a censura: parece que o gênio devastador, esse espírito da ignorância e da maldade, não farto de forjar cadeiras para agrilhoar os homens, concebendo essa monstruosa idéia, voara sobre a terra e a suscitara aos déspotas! Não admira pois, que eles a tenham abraçado, decretado e autorizado, porque ela lhes é tão própria, como a maior cooperadora do despotismo, quanto a liberdade da imprensa é o antemural da liberdade dos

\footnotetext{
${ }^{11}$ Diário de Pernambuco, 5/2/1828.
} 
povos. Não admira que os déspotas temam a imprensa mais que quantos exércitos se possa imaginar"12.

Fica clara a relação que se estabelece entre o poder absoluto, detentor do privilégio da informação a respeito dos negócios públicos, e a irracionalidade de sua legislação. No século XIX, o das Luzes, não havia espaço para tal modo de conduzir a política - era a racionalidade, a verdade das coisas, o objetivo da administração liberal, e esta só poderia ser atingida por meio de debates abertos, dos quais pudessem participar todos os que desejassem, informados corretamente sobre todos os aspectos que poderiam comprometer seu julgamento, especialmente aqueles relativos aos negócios do governo. Essa idéia, particularmente, é traduzida nas seguintes palavras, proferidas meses antes no Diário de 15/2/1829, em artigo especial sobre a lei de liberdade de imprensa: "Se com o ardor da discussão e com o esforço de indagar é que se apura quanto a habilidade intelectual é capaz de produzir - a não ser este o meio de chegar à verdade, qual será ele?"

Outra função atribuída à imprensa era a de contribuir com o avanço da instrução geral, explorada de formas diferentes pelos jornais da Corte. A Aurora Fluminense, defendendo a necessidade de maior divulgação dos trabalhos ministeriais, afirma:

"Julgamos que sem luz, sem muita luz, nada poderemos levar adiante, nem conseguiremos que o Povo tome parte naquilo que não conhece, e que ao primeiro aspecto se afigura esconderem-lhe. É necessário que os dignos membros do governo (...) se afastem dessa rotina de velhos e tortuosos chicaneiros (...) que tão mal se casa com o espírito do tempo e com as nossas instituições"13.

A preocupação com a publicidade dos atos do governo está intimamente relacionada, pelo redator, à educação política da população brasileira, que deveria se habituar a vê-los publicados e a formar juízo sobre eles, primeiro passo para que pudesse influir nas decisões ministeriais. A edificação de um povo interessado e engajado politicamente, então, dependia de uma pedagogia que o capacitasse para a atuação política, a ser encampada tanto pelo governo quanto pelos redatores independentes, e veiculada primariamente pela imprensa.

\footnotetext{
${ }^{12}$ Diário de Pernambuco, 20/08/1829.

${ }^{13}$ Aurora Fluminense, 25/2/1828.
} 
O Jornal do Commercio também expressa, em momentos distintos e relativamente distantes - o que sugere certa estabilidade de tal ponto de vista na redação do jornal -, esse comprometimento com a ilustração do povo, mas de modo a afastá-lo da política para que os verdadeiros detentores do poder pudessem governar em paz:

"Se o redator do Jornal do Commercio não receasse ser taxado de pedantismo, recomendaria em nome do bem público aos que têm tomado sobre seus ombros a árdua tarefa de guiar a opinião pública, que, em vez de doutrinas perigosas, por não poderem ser bem compreendidas por grande parte de seus leitores, preferissem instruir o público nos princípios da moral, base de todas as virtudes, no amor à ordem, e obediência às leis"14.

"É hoje o regresso o grande tópico de todas as folhas públicas, o objeto das conversações, a senha com que saúdam e fazem conhecidas certas pessoas, e a palavra mágica que aviva esperanças, e desperta entusiasmo, em parte amortecidos (...). Chamem a população aos cuidados domésticos, à indústria, ao trabalho: apartá-la da política, das intrigas, é o único meio que resta a tentar, e que provavelmente será mais profícuo que envolvê-la em novos partidos, em progressivos e regressivos (sic) (...). Interessem-se todos na marcha administrativa, porque o bem ou mal sobre eles vem a recair; mas consintam que só as autoridades governem, e trate cada um de seus necessários negócios, que haverá sossego e prosperidade no país; mas, sobretudo, evitem novas dissensões, e não venha uma simples palavra atear de novo no Brasil intrigas em parte amortecidas" $"$.

Esse mesmo tipo de manifestação, a respeito da preocupação popular com os negócios do Estado, já havia sido publicado anteriormente pelo Jornal do Commercio, no tom sarcástico (e aristocrático) do padre Miguel do Sacramento Lopes Gama, conhecido pelo nome do jornal que publicava em Recife, o Carapuceiro:

"O alfaiate, ao invés de estar em sua loja, cortando panos e fazendo roupa, traz a corda aos fregueses semanas, e semanas; por que vive talhando governos, gizando constituições, e alinhavando rusgas: o sapateiro já não quer saber de couros e solas; só fala em gazetas. O barbeiro, dá para publicista! Isso é uma

\footnotetext{
${ }^{14} 20 / 7 / 1830$

15 9/5/1836.
} 
peste; é nossa cólera morbus. (...) enjoa ver por este nosso mundo tanta gente ociosa, e todos profundíssimos políticos"16.

A idéia defendida pelo Jornal do Commercio está clara: a imprensa deveria lembrar ao povo suas obrigações cotidianas, estimular sua dedicação ao trabalho e incitar seu amor ao sistema constitucional e sua obediência às leis, em vez de incentivar iniciativas políticas - estas cabem às autoridades, às quais deveria ser garantida a calma necessária para a boa governança. Mais do que tudo, a imprensa não deveria engajar-se na criação de novas cisões, nem no encorajamento político do povo, mas sim trabalhar pela unidade da classe política e pela tranquilidade do país. ${ }^{17}$

Da educação moral da população também dependia, segundo o mesmo periódico, a obediência das leis de abuso da imprensa:

“O remédio dos abusos inevitáveis da Liberdade da Imprensa não está na Lei: diremos ainda mais, supomos que nunca poderá estar aí: é mister buscá-lo debaixo de outra forma, e em um modo mais sólido. Este remédio é a ilustração, e a moral pública: é a justa indignação, e desprezo, com que os homens sensatos olham o homem petulante que injuria aleivosamente a um cidadão, ou calunia-o debaixo de qualquer pretexto" 18 .

Como a instrução pública dependia de uma boa imprensa, o movimento do jornal cria um sistema de retroalimentação no qual a melhoria da educação repercute na qualidade da imprensa (que se dirige a leitores cada vez mais conscientes e exigentes dos atributos necessários ao bom jornalista), o que por sua vez contribui ainda mais para a ilustração dos cidadãos.

Quando se trata de defender a expansão do periodismo por meio da redução dos impostos de frete, no entanto, o Jornal do Commercio de 11/8/1836 adota uma posição mais semelhante a dos jornais liberais moderados. Reivindicando uma reforma na legislação, afirma que "custa conceber como os legisladores (...) consentiram em carregar com semelhante gravame os veículos da instrução.” Mais à frente, afirma:

\footnotetext{
${ }^{16}$ Jornal do Commercio, 2/10/1832.

${ }^{17}$ Os dois últimos trechos destoam inegavelmente do anterior, extraído da Aurora Fluminense. A discordância é bem ilustrativa da distância ideológica entre os dois jornais. O Jornal do Commercio sempre esteve próximo do governo imperial e defendia abertamente os ministros dos ataques proferidos contra eles, seja da Câmara dos Deputados ou de outros periódicos. A Aurora Fluminense, pelo contrário, destacou-se por um diálogo recorrente com a Câmara a respeito de suas obrigações e decisões, e também pela preocupação em resguardá-la dos ataques daqueles que chamava de absolutistas ou déspotas.

18 13/01/1830.
} 
"A lei [que estabelecia o pagamento do porte dos jornais] tende a sufocar um ramo da indústria nascente entre nós, a nobre arte tipográfica (...). A lei vigente obsta a que se instrua o povo, a que se desenvolvam os dons com que a natureza o dotou; ataca de alguma forma a liberdade da imprensa, um dos primeiros elementos do sistema constitucional. E como poderão as províncias longínquas conhecer as necessidades do país? Onde irão elas saber se os seus representantes merecem a confiança que neles depositaram, e se se têm mostrado dignos de novamente as representarem, quando tenham de procurar outra vez os seus sufrágios? (...) O excessivo imposto que ora pesa sobre os periódicos contribui a perpetuar esta ignorância; cumpre então removê-lo".

O mais importante aqui é a lembrança do papel fundamental exercido pelos periódicos no fornecimento de informações a respeito da atuação dos representantes políticos das províncias, que não gozavam do privilégio dos habitantes da Corte de poder assistir às sessões legislativas, e por isso dependiam dos relatos publicados nos jornais. Sem eles, os eleitores não poderiam tomar decisões acertadas nas eleições, e isso fatalmente comprometeria o sistema representativo brasileiro.

Forma mais direta encontrada para explorar o tema da liberdade de imprensa foi a discussão sobre a legislação que a regulava. O exemplo mais bem acabado dessa iniciativa foi encontrado no Diário de Pernambuco, que entre os dias 1 e 16 de fevereiro de 1828 publica um longo editorial no qual expõe a organização que considera ideal para a lei de liberdade de imprensa.

No primeiro dia de publicação, $1^{\circ}$ de fevereiro, o autor que, como era usual, assina com um pseudônimo, Americus, faz considerações gerais sobre a imprensa e sua importância no combate ao absolutismo: "Tanto mal tem feito a liberdade de imprensa à supressão dos déspotas como à licença dos liberais", e enfatiza a necessária virtude de encontrar o meio termo entre o ataque contínuo ao governo e aos direitos e a adulação que não comporta a censura necessária ao progresso do Estado. A crítica ao governo era vista como uma das principais funções da imprensa, que deveria trazer ao público as malversações de funcionários e políticos, assim como a situação dos negócios governamentais. Vale notar também que não é somente o despotismo a preocupação do autor; a licenciosidade dos liberais, que muitas vezes extrapolavam os limites da monarquia constitucional, chegando a sugerir a república ou outros avanços políticos modernos, também deveria ser contida pela boa imprensa e pela boa legislação. 
Americus continua, definindo os casos de abuso de liberdade de imprensa nos quais caberia punição:

"A licença perigosa na liberdade de imprimir consiste unicamente em injuriar, em caluniar, e em concitar a desobediência ou a insurreição (...). A injúria, a calúnia, a sedição vêm portanto a ser o que uma lei de liberdade de imprensa deve definir e castigar".

As penas para os escritores que se atrevessem a violar a vida privada do cidadão ou denegrir sua imagem pública com mentiras, de acordo com o Diário de Pernambuco na seqüência de artigos, deveriam consistir basicamente em reparações, como multas e a imposição de desdizer-se em público, sendo o autor contrário a penas excessivas, com o risco de desincentivo à atividade jornalística ${ }^{19}$.

Apesar de preocupar-se com a faceta negativa da liberdade de imprensa, Americus dedica a maior parte do artigo a elencar as possibilidades de crítica ao governo:

"Primeiramente, um governo pode ser censurado quanto ao seu sistema em geral, quando a linguagem for temperada e não veemente; sobretudo quando não houver alusões maliciosas a intenções perversas, e a desígnios sinistros. Fora disto tudo o mais é permitido como censura; nem há outro meio de mostrar os vícios de uma administração (...). Em segundo lugar, num governo constitucional, em que o bom êxito do esquema depende "intutum" da boa escolha dos representantes, é também impossível haver esta boa escolha se não houver liberdade de censurar (...). E como pode o eleitor, sem a censura e o exame da liberdade de imprensa, conhecer os caracteres de quem se apresenta com as qualificações ostensivas de representante? Como pode fazer-se conhecida a conduta dos que foram eleitos? É uma verdade confirmada pela mais constante experiência que onde quer que um corpo de indivíduos manejar o poder, se o público não tiver meios de conhecer como eles o manejam, terão eles sempre meio seguro de se aproveitarem da sua situação e de a converterem só em seu benefício (...). Além disso, não se pense que a censura da imprensa haja de restringir-se a mera narração de um fato; será permitido também formar juízo

\footnotetext{
${ }^{19}$ Tal sistema de condenação foi sugerido, durante os debates da lei de abuso, pelo então deputado Bernardo Pereira de Vasconcellos, para quem a principal punição a ser cominada aos infratores era a obrigação de retratar-se publicamente no mesmo jornal em que circulou o texto criminoso. Apesar do empenho do deputado, sua sugestão não venceu - seus colegas acreditavam na necessidade de penas mais rígidas para afastar os publicistas dos ímpetos caluniadores.
} 
sobre a utilidade, justiça e moralidade desse fato (...). Se a censura consiste unicamente na liberdade de dizer cada um francamente a sua opinião, faz aparecer a verdade no meio do contraste, sem degradar nem insultar a autoridade do legislador ou do magistrado (...) poucas vezes se erraria em chegar a uma conclusão exata e verdadeira" ${ }^{20}$.

Há de se reparar, inicialmente, na menção à linguagem adequada a uma discussão política: era generalizada, à época, a noção de que as boas exposições deveriam encaminhar-se em linguagem culta e tranquila, sem arroubos apaixonados ou ofensas de qualquer tipo.

O segundo ponto de interesse é a implicação entre sistema representativo e liberdade de crítica, estabelecida por conta das eleições e da consequente necessidade de informar os eleitores a respeito da atuação de seus representantes (no caso daqueles que concorressem à reeleição) ou de seu caráter e qualificação. Aqui surge uma função da imprensa ainda não tratada pelo autor, mas presente em diversas outras manifestações de redatores, que é a de participar ativamente das eleições, elegendo candidatos ou arruinando candidaturas, mas sempre trabalhando pela instrução do público naquilo que é de seu interesse.

Por fim, há a reivindicação de que à imprensa não é reservado o direito de somente relatar acontecimentos, sem exprimir juízos de valor sobre eles. Americus defende que aos periodistas seja amplamente permitido divulgar suas opiniões sobre os fatos, a fim de que o debate permita que se chegue à verdade. Repete-se a crença iluminista no poder libertário do debate aberto e racional, e a função atribuída (também autoatribuída) aos publicistas de formarem e guiarem a opinião pública nacional.

No ano seguinte, no entanto, muda sensivelmente o tom empregado pelo jornal na defesa da liberdade de imprensa, com certeza por conta dos levantes populares nas proximidades de Recife (Afogados e Santo Antão) e da crescente propaganda absolutista levada a cabo por jornais como o Cruzeiro e o Amigo do Povo. ${ }^{21}$ Ante tal ofensiva política, o jornal passa a exaltar os redatores, com linguagem inflamada, a cumprir sua missão constitucional:

"Sendo bem regulada a liberdade de imprensa, justamente considerada por todos os políticos como o ante-mural da liberdade civil e política (...); sendo ela o

\footnotetext{
${ }^{20}$ Diário de Pernambuco, 14/02/1828

${ }^{21}$ Como recurso irônico, todas as vezes que o nome desta última folha era citado no Diário de Pernambuco, a palavra "Amigo" vinha impressa de ponta-cabeça, exprimindo a inversão de sentido que os redatores julgavam ocorrer.
} 
verdadeiro termômetro pelo qual se pode graduar o estado de civilização e adiantamento das nações (...); e enfim o espelho onde os maus vêem a enormidade de seus crimes; também é mister confessar que nenhuma coisa é tão perigosa na ordem moral e política quanto o abuso dessa liberdade tão inestimável quando bem regulada. Ultrapassadas as barreiras legais, ela é o veículo dos insultos à divindade; dos sarcasmos atirados às autoridades supremas, em cujas mãos reside o poder; introduz a desconfiança entre os iguais, rompe o nexo social, e o povo é lançado na desordem e na anarquia, e tudo é confusão (...). É aproveitando-se desse mimo do céu, e evitando os escolhos e parias perigosos que o cercam a cada passo, que os nossos escritores públicos, votados de coração ao interesse da pátria, devem tomar a pena para aconselharem os Povos ao amor e aferro às boas instituições constitucionais (...), à devida obediência às autoridades e levando-os como que pela mão à prática das virtudes cívicas; enfim fazendo-lhes ver que o interesse particular deve confundir-se no interesse geral, assim como a unidade na multiplicidade do todo; deste modo eles preenchem um fim e ministério muito nobre e elevado, e fazemse dignos dos nossos respeitos (...); se porém eles, vendidos a um partido, ou este tenda para a democracia ou absolutismo, (...) manejam a pena para proferirem insultos (...) e mancham suas páginas com o fel da maledicência (...) e ridicularizam a torto e a direito as coisas mais sagradas, longe de colherem as bênçãos de seus leitores, vêem chover sobre suas cabeças maldições (...). Não é revolucionando os povos que os nossos escritores devem procurar a felicidade do povo; é instruindo-o nas verdadeiras máximas da religião e da moral, ensinando-o a respeitar o governo e as autoridades e aos outros homens, fazendo-o gostar em paz das doçuras do governo constitucional, evitando, se lhes é possível, o aparecimento de qualquer tendência para mudar o sistema atual, dando-lhes exemplo de moderação e de virtude: é deste modo que eles podem e devem trabalhar para a felicidade de nossa pátria (...). É por fim do mais estrito dever [dos nossos escritores públicos] velarem na manutenção e progresso do sistema constitucional, mostrando sua excelência e primazia sobre todas as outras formas de governo, delatando aqueles que (...) se ocuparem por espalhar uma doutrina oposta e subversiva ou trabalhar por derrubar esse edifício majestoso, para sobre as suas ruínas levantarem o vacilante e perigoso governo democrático, ou carunchoso e sediço absolutismo (...). Se porém nossos 
escritores públicos não seguirem o trilho verdadeiro, que temos marcado, adeus liberdade de imprensa, adeus a melhor das garantias constitucionais; sua licença atrairá o ódio e a execração pública, e seu silêncio e nulidade a fará reputar desnecessária a liberdade dos povos"22 (grifos meus).

O início da citação reafirma o princípio da liberdade de expressão: é pela imprensa que se pode avaliar o grau de avanço político atingido por uma nação (evidentemente, numa escala que toma como base a civilização europeia). Contudo, a ênfase do artigo não cai sobre as vantagens de um jornalismo livre, mas nos perigos de seu exercício destemperado. Demonstrando um imenso temor em relação ao potencial subversivo da imprensa, afirma que ela pode estremecer as relações sociais e estimular o povo à desobediência e revelando certo sentimento de medo da multidão.

Aos escritores, o editorial conclama que se esforcem no sentido de fortalecer o sistema constitucional perante o povo, defendendo as "boas" instituições (dá essa classificação por óbvia, e não se preocupa em defini-las) ${ }^{23}$ e mostrando sua vantagem em relação às outras formas de governo, então conhecidas e defendidas como opções de organização do Brasil: a democracia ou o absolutismo. O papel pedagógico não poderia estar mais explícito: a condução tranquila do povo rumo à verdade política e moral, jornada edificante da qual surgiria grandioso o império brasileiro, deveria ser encampada pelos "bons” jornalistas - aqueles que, compreendendo o interesse geral, demonstrariam zelo patriótico suficiente para deixar de lado paixões e partidos momentâneos. Se, no entanto, o periodismo mostrar-se incapaz de compreender esse aviso, colocará em risco não só sua credibilidade como porta-voz da opinião pública brasileira, como também, e mais gravemente, a própria idéia de liberdade política e civil.

A aprovação da lei contra os abusos de imprensa, em setembro de 1830, enseja, alguns meses depois, um editorial celebratório do Diário de Pernambuco em 12/11/1830:

(...) em que parte da Terra, e em que quadra política por lamentável e calamitosa, a imprensa tem apadrinhado mais do que em Pernambuco criminosos desvios de educação, insultuosas exprobações particulares, odiosas e abjetas individualidades, torpes e privadas discrepações? Quando, e em que nação viu-

\footnotetext{
${ }^{22}$ Diário de Pernambuco, 07/05/1829,

${ }^{23}$ Da mesma forma, toma como dado e consensual o "interesse da pátria", ao qual deveriam servir os redatores das folhas.
} 
se a imprensa, que só deve ser destinada à consagração da verdade, que deve servir somente de depósito aos sagrados princípios da casa dessa divina filosofia, que tem descortinado entre as trevas do despotismo os sacrossantos direitos do homem, e que parece inventada para ser fiel confidente das elucubrações do sábio, reduzida ao vil estado de fonte de corrupção, de foco de desmoralização?

Uma tal aberração do legítimo fim (...) não podia durar muito, era necessariamente insubsistente; e os gravíssimos e palmares defeitos da lei que nos regia sobre a liberdade de imprensa não podiam certamente escapar da sagacidade e patriotismo dos nossos beneméritos representantes (...) não hesitaram todavia um rodear a que hoje nos oferecem daquelas cautelas e precauções repressivas que tanto invocavam todas as pessoas esclarecidas e sensatas, sem contudo lançar mão desses meios proibitivos, que são sempre odiosos, nem de forma alguma ferir e mutilar a vasta e espaçosa base sobre que deve repousar e fundamentar-se uma instituição desse gênero.

Na verdade, quem ousará censurar a admirável disposição da nova lei, em que se exige como condição capital que o responsável de qualquer escrito, desde o impressor até o autor, esteja no perpétuo gozo de seus direitos? (...)

(...) nós sabemos que em legislação não há bondade absoluta, por isso que as leis devem se acomodar aos usos, aos hábitos, ao caráter, à civilização (...) dos povos; e por consequência a lei em questão pode ser demasiadamente rigorosa e sobremaneira severa num país onde não hajam colunas e escravos e onde não se violem os princípios da decência e do decoro e ser (desgraçadamente) boa para o Brasil, onde essa infame cáfila de réprobos e servis não cessa de conspirar contra as nossas liberdades, ora atacando com grosseiros doestos o Código sagrado que juramos (...), ora tentando poluir com cavilações e calúnias a inatacável reputação dos liberais (...). Cuide o povo em nomear um júri esclarecido e verdadeiramente popular (...), e então veremos aventada e discutida a marcha das autoridades, conhecidas e analisadas as instituições do governo, patenteados e corrigidos os abusos do poder, apoiada e garantida a inviolabilidade da lei, e finalmente protegidos e respeitados a vida privada e o segredo das famílias.

Para além da própria iniciativa de felicitar os representantes pela feitura da lei, que, como outras citadas anteriormente, ilustra o modo pelo qual os periódicos se dirigiam aos deputados, o interesse do extrato está na ressalva do último parágrafo. $\mathrm{O}$ 
redator reconhece que a dureza da lei não caberia para outras nações (implicitamente consideradas mais adiantadas), mas é necessária no Brasil, que ainda lutava contra os servis e os revolucionários. De fato, na sua visão, a lei era um avanço e dali em diante só dependeria do povo, a quem cabia a nomeação dos jurados dos processos, a sua justa aplicação e a consequente moralização da imprensa. A idéia de que esses rigores não eram compatíveis com o regime liberal, mas mesmo assim necessários diante da situação política do país, também surgiu nesses mesmos termos quando da discussão da lei na Câmara dos Deputados, revelando a existência generalizada do sentimento de que se civilizava o Brasil por meio das instituições que então se implantavam. Esta percepção é enunciada muito mais frequentemente do que aquela que previa o seu fracasso devido à pouca inclinação dos brasileiros para um governo liberal.

Tanto a atuação política direta quanto a análise filosófica, publicadas pelos jornais analisados, sugerem que os redatores dessas folhas compreendiam a si mesmos, e assim atuaram, como agentes políticos importantes na conformação do sistema constitucional, seja pela ação direta de cobrança das autoridades, seja pelo exercício de formação e informação da nascente opinião pública brasileira.

Esse entendimento só seria possível num contexto no qual a configuração de uma monarquia constitucional representativa se tratasse de uma séria tentativa de dotar o país de instituições liberais, cuja finalidade era permitir uma inclusão controlada (e limitada) de novos setores sociais na administração do Estado, angariando, desta forma, um novo tipo de legitimidade, baseada no seu caráter público.

O cuidado em informar os cidadãos da conduta de seus representantes, e mesmo de membros do governo cujos cargos não dependiam de eleições, está claramente relacionado com a percepção de que os negócios estatais deveriam ser submetidos ao princípio da publicidade, segundo o qual as informações a respeito da administração do Estado são de interesse e domínio público, a fim de que sejam continuamente submetidos a um processo de debate que garantiria sua racionalidade e correspondência com o interesse geral. Em termos políticos mais imediatos, isso significava que agora o poder estava sujeito a uma vigilância pública da oposição que tinha legitimidade para questionar suas ações.

A preocupação com a instrução pública, de maneira análoga, inscreve-se na percepção de que somente um povo instruído nos benefícios de seu sistema político poderia desfrutar de uma existência política completa, e a ausência de um nível aceitável da educação moral e formal foi o que justificou, durante muito tempo, a 
exclusão de amplas camadas sociais da cidadania ativa. Como membros do seleto grupo de cidadãos completos, alguns publicistas externaram sua disposição de concorrer com os meios de que dispunham para aumentá-lo, tanto por meio de reivindicações pela melhoria da instrução pública formal quanto pela inserção de conteúdo educativo em suas próprias folhas. Outros revelaram ideais políticos mais elitistas, advogando a separação entre os reinos do trabalho e da política - o segundo, naturalmente, reservado aos cidadãos mais capazes, mais ricos, mais instruídos. Mas mesmo esses reconhecem a importância da extensão da educação formal, a fim de que os responsáveis pelo mundo do trabalho o fizessem de forma mais eficiente e disciplinada.

De qualquer forma, fica registrado o consenso dos redatores dos periódicos analisados em torno da adoção e manutenção do sistema monárquico constitucional representativo e também a disputa por influência na regulamentação de seu funcionamento, pois ainda estavam em aberto questões fundamentais, como, por exemplo, a divisão das atribuições dos poderes executivo e legislativo, que quando decididas alterariam profundamente a fisionomia do regime. Além disso, é notável a ausência do discurso da incompatibilidade de um governo representativo com o caráter do povo brasileiro. O que se observa, ao contrário, é a disposição desses atores em admitir ajustes, temporários ou não, no próprio sistema, a fim de manter o modelo geral de organização política e de colaborar com o aperfeiçoamento das instituições, naturalmente de acordo com o que acreditavam ser o interesse nacional. 


\section{Considerações finais}

Esta dissertação tentou analisar alguns dos pontos mais importantes da regulação da esfera pública no sistema representativo da primeira metade do século XIX: a produção de uma legislação sobre os abusos da liberdade de imprensa e o esforço parlamentar para tornar público o seu processo decisório, por meio da publicação de diários e anais. Subsidiariamente, também foi considerada a postura de alguns periódicos em relação ao poder legislativo, mapeando quais as principais estratégias de diálogo estabelecidas pelos jornalistas com a Câmara dos Deputados, a fim de explicitar qual seria a função que os redatores se auto-atribuíam num regime que primava pelo respeito - e obediência - à 'opinião pública'.

O exame da legislação dirigida à imprensa, e de sua aplicação, entre as décadas de 1820 e 1840, revela primeiramente que o discurso liberal que pregava sua liberdade foi bem recebido e internalizado pelas elites brasileiras. Depois da abolição da censura prévia, oficializada pelas Cortes portuguesas em 1821, essa opção de contenção dos abusos nunca mais foi cogitada pela elite política brasileira, o que não é pouco, especialmente se se pensa na grande instabilidade política reinante no país durante o período. Além disso, essa foi uma área que sempre recebeu a atenção dos governantes, tanto ministros como parlamentares, que procuravam normatizar a atividade, o que garantia certa estabilidade e clareza das regras do jogo. Pode-se argumentar que tais regras eram feitas de modo a limitar as possibilidades de expressão - certamente o faziam, e era exatamente para isso que eram produzidas - mas, fazendo isso, ao mesmo tempo regulamentavam os limites da repressão do Estado contra os jornais da oposição. E há de se ter em mente que o liberalismo brasileiro era profundamente marcado pelas idéias francesas de limitação do exercício das liberdades individuais em benefício do bem-estar e interesses gerais, o que legitimava as iniciativas de regulação da liberdade de expressão que cumprissem o objetivo de salvaguardar a ordem pública. Foram poucos os defensores de uma liberdade realmente ampla ou da eliminação de penas criminais aos escritores que eventualmente incorressem em abuso.

O problema sempre esteve, na verdade, na determinação do que seriam ou não os abusos que a imprensa poderia praticar, e é nesse campo que faz sentido falar em posições mais ou menos liberais ou conservadoras. Interessava ao governo e a seus apoiadores definir contornos imprecisos entre as condutas permitidas e proibidas, a fim 
de garantir margem de manobra para perseguir seus opositores sem criar grandes desconfortos políticos - pois, por maior que fosse a capacidade ministerial de estabelecer medidas de exceção e passar por cima das leis, isso sempre gerava reações legislativas. Nesse sentido, é marcante a atuação do parlamento como defensor da liberdade de imprensa contra as arbitrariedades do executivo - o que se deu por motivos vários: durante o período estudado, foram raros e curtos os momentos em que o governo contou com apoio da maioria da Câmara, o que a fazia um espaço privilegiado para a atuação da oposição; além disso, é realmente de se esperar que os homens do legislativo, compreendendo seu potencial no novo regime, se esforçassem para consolidar essa esfera de poder, exigindo que o seu trabalho regulatório fosse obedecido pelo executivo. Por último, a imprensa, assim como a tribuna parlamentar, era um espaço privilegiado para o exercício da oposição política, e por isso sua autonomia era defendida por aqueles deputados que criticavam o governo.

A generalidade da definição de abuso de imprensa, se por um lado facilitava ao governo interpretar como ameaça à ordem e sossegos públicos, por exemplo, as críticas que fossem feitas a ele em determinada questão, por outro facilitou a defesa dos jornalistas perante os tribunais populares. Desde 1822, os crimes de imprensa eram julgados pelo júri, uma garantia liberal de que os crimes políticos (ou de opinião) não seriam considerados por juízes de carreira, muito frequentemente funcionários fiéis ao governo. A historiografia sobre o período confirma a hipótese de que os jurados eleitos seriam mais inclinados a absolver os jornalistas pronunciados, fornecendo muitos exemplos de casos (ainda que não se baseie, para tanto, no estudo dos respectivos processos criminais); o exame de fontes coevas - os comentários ao Código Criminal fazem a crítica conservadora do mesmo fenômeno, e para os fins deste trabalho considerou-se tais informações suficientes para afirmar (provisoriamente) que o processo judicial estabelecido pelas leis de imprensa foi favorável à efetivação de uma esfera de liberdade ampla para os padrões da época.

Por fim, acompanhar a implementação das leis de imprensa no Brasil imperial é assistir à crescente institucionalização do Estado de direito no país. Isso porque, ao longo do tempo, verifica-se que são interpostos cada vez mais obstáculos à ação arbitrária do poder executivo. No período que antecedeu a independência e durante o Primeiro Reinado, a principal maneira encontrada pelo ministério para conter a onda oposicionista veiculada pelos periódicos era o estabelecimento de devassas, instrumentos extralegais que instituíam, em locais e por períodos determinados, a 
suspensão das garantias individuais em nome da investigação de pessoas que ameaçariam a ordem estabelecida. Com os devidos processos de investigação e julgamento suspensos, ficava fácil para as autoridades prenderem, julgarem e condenarem sumariamente seus opositores. Como se disse, tal procedimento criava grandes atritos entre ministério e Câmara, mas nesse primeiro momento ainda era passível de ser utilizado.

A situação muda durante a Regência. Então, o recurso a medidas violentas contra os jornalistas da oposição não parece estar disponível ao executivo - e especificamente contra esta categoria, a julgar pela força empregada pela repressão contra as revoltas regionais. Foi feito um grande esforço para conter a veiculação das críticas e os projetos de país antagônicos ao que estava sendo implementado, sim, mas ele não passou ao largo do processo legal; e justamente por isso, o esforço foi no sentido de endurecê-lo. O regente Feijó utilizou um decreto para modificar as instruções aos juízes dos crimes de abuso de imprensa, tornando mais rígidas as condições para que a responsabilidade por um impresso (inicialmente, do tipógrafo) fosse passada adiante (para o editor ou autor), numa tentativa de conseguir mais condenações, e com isso dissuadir os opositores de continuarem com suas publicações (a crer nas fontes, não conseguiu). Mantiveram-se as garantias e direitos constitucionais, e mesmo o processo judicial não foi significativamente alterado, o que revela a consolidação da ordem legal no país.

Antes de passar ao próximo tópico, vale uma palavra sobre as razões que justificariam, para os deputados, a defesa da liberdade de imprensa. Elas acabam por revelar suas concepções de boa e má imprensa. Além, é claro, de constituir o principal meio veiculador e formador da 'opinião pública' - e por isso necessário para a constituição sadia da 'civilização', termo hoje substituído por 'modernidade' -, a imprensa era um instrumento importante para a educação da massa da população, tanto moral quanto política. Foi discutida a idéia predominante dos deputados do que seria o povo, um agregado de indivíduos que não compartilhava dos códigos morais nem das capacidades intelectuais das elites, e por isso era necessário que se lhe guiasse, ensinasse seus direitos, deveres e interesses. Essa é a que foi chamada neste trabalho de 'função pedagógica' da imprensa.

A outra função da imprensa que salta dos discursos dos deputados é propriamente política, e talvez por isso mesmo mais aristocrática. Ela deveria informar os cidadãos (e é notável a mudança do termo, muito menos abrangente) a respeito da 
atuação de seus representantes, agentes do executivo e funcionários públicos; um fiscal atento às malversações do interesse público, denunciando-as sempre - tornando-as de domínio público.

Em relação à publicidade dos atos do governo a conclusão não é muito diferente. Também neste aspecto, o ideário liberal estava introjetado nos parlamentares e muitos se esforçaram para colocá-lo em prática. Desde a abertura das Câmaras a necessidade de vulgarizar o conhecimento do que se passava ali foi apregoada, destinaram-se verbas para providenciar que os discursos fossem colhidos, impressos e distribuídos e, num segundo momento, para remunerar os jornais que estivessem dispostos a fazer isso. Inclusive, pode-se dizer que o empreendimento da Câmara abriu um novo filão de atividade para os jornais da Corte, que passaram a competir pelo subsídio oferecido pela publicação de maneira tão insistente que sugere que ganhavam muitos leitores e algum prestígio com isso. Os meandros dessa competição registrados pelos anais também revelam articulações políticas entre periódicos e deputados que merecem ser melhor analisadas, pois possibilitam mapear as redes de lealdade e apoio políticos entre a 'opinião pública' e os políticos.

As justificativas para o empenho na publicação dos trabalhos são o ponto de contato entre este tema e a questão da liberdade de imprensa, pois as preocupações evidenciadas são as mesmas. A primeira é a formação da opinião geral - era urgente que se instruísse o povo nas vantagens do sistema representativo em relação ao despotismo do Antigo Regime e também à democracia republicana, e nisso os diários distribuídos às províncias poderiam ajudar, pois eram os documentos do 'fervor' e da 'justeza' com que os parlamentares defendiam os interesses nacionais. É a vertente pedagógica do iluminismo, defensora da idéia de que a adesão ao regime constitucional-representativo, e mesmo à unidade nacional, nos moldes como vinha se estabelecendo era uma questão menos política do que de educação.

O segundo motivo era a necessidade de informar os constituintes do trabalho de seus representantes. Além de ser um direito essencial à formação da opinião pública esclarecida, era uma prestação de contas do deputado, que tinha ali registrada sua atuação para que os eleitores decidissem se seria merecedora de um novo mandato - a vertente política/eleitoral.

Finalmente, a relação de periódicos com o poder legislativo. Apesar de a amostra analisada não ser significativa, foram encontradas diferenças substanciais na maneira de cada um endereçar-se ao parlamento, determinadas, obviamente, pelas 
respectivas orientações e lealdades políticas. O mais próximo do Imperador e seus ministros censurava rispidamente a inação da Câmara, ajudando a criar a imagem do parlamento como um órgão 'preguiçoso' e descolado do país real, ao mesmo tempo em que noticiava as ações governamentais e elogiava os ministros. Por sua vez, aquele redigido por um deputado elogiava as iniciativas parlamentares, reforçava a linha adotada na Câmara pelo seu redator e criticava duramente as invasões do poder executivo nas prerrogativas do legislativo. Ainda assim, observaram-se pontos de contato fundamentais, como uma inclusão social restrita e controlada, garantindo que a política continuasse a ser domínio dos 'melhores', a defesa da monarquia e da observância da Constituição (com interpretações distintas, como se viu).

A grande constante do discurso e prática observados neste trabalho é a defesa e observância de uma específica legalidade. Com isso não se quer dizer que o Império brasileiro fosse uma terra de liberdade, pois é claro que toda ordem jurídica repousava sobre desigualdades óbvias, a maior delas a escravidão. No entanto, a desigualdade sempre foi inerente ao liberalismo político ou doutrinário, e mesmo o liberalismo econômico do laisser-faire era formado pela premissa da autonomia do cidadãoproprietário que, levada às últimas conseqüências, inviabilizava qualquer restrição jurídica à sua propriedade. Assim, a escravidão não inviabilizava um regime liberal ${ }^{1}$.

Assim sendo, a materialização institucional do liberalismo, o governo representativo, servia aos interesses de uma elite central que, ao mesmo tempo em que julgava fundamental incluir na dinâmica do governo as elites provinciais, não pretendia incluir democraticamente outros setores sociais. E, nesse sentido, a liberdade de imprensa no Brasil foi objeto de restrições compatíveis com as idéias do tempo. Neste caso específico, as regulações estatais foram obedecidas, a possibilidade de expressão era relativamente ampla, e mesmo assim não se observou significativa inclusão da população no mundo letrado, nem sua adesão a partidos socialmente mais arrojados. Provavelmente, porque a finalidade da livre expressão era exatamente a de colocar em contato e debate setores divergentes das elites, e porque nunca esteve em seus planos qualquer tipo de inclusão democrática. Ou seja, nada havia de errado com essa

\footnotetext{
${ }^{1}$ Alfredo Bosi, A escravidão entre dois liberalismos. Neste texto, o autor demonstra como a antinomia liberalismo/escravidão constitui um paradoxo que é somente verbal, pois o primeiro não teria se constituído, no Brasil, uma ideologia dominante. In Dialética da Colonização. São Paulo: Companhia das Letras, 1994. Em outra chave de interpretação, Domenico Losurdo, na sua Contra-história do Liberalismo, traça a genealogia da defesa da escravidão no pensamento liberal norte-americano e britânico, relacionando-a com a efetivação histórica dessa filosofia política. Aparecida: Idéias \& Letras, 2006.
} 
instituição liberal - pelo contrário, é um exemplo do sucesso de nossas elites em seu esforço de se manterem no poder e na legalidade. 


\section{Fontes e referências bibliográficas}

\section{Fontes:}

Anais da Câmara dos Deputados

Anais do Senado

Coleção das Leis do Império

Constituição do Império do Brasil

Braz Florentino Henriques de Souza. Lições de Direito Criminal. Paris: V va J. P. Aillaud Guillard E. C ${ }^{\mathrm{a}}$, 1872. Lição $3^{\mathrm{a}}$ : Dos responsáveis nos crimes de liberdade de exprimir os pensamentos (originalmente publicada em 1866)

J. Liberato Barroso. Questões práticas de Direito Criminal. Rio de Janeiro: B. L. Garnier, 1866.

Manoel Mendes da Cunha Azevedo. O Código penal do Império do Brasil com observações sobre alguns de seus artigos. Recife: Tipografia Commercial de Meira Henriques, 1851

\section{Referências bibliográficas}

Alexandre, Valentim. Os sentidos do Império. Questão nacional e questão colonial na crise do Antigo Regime português. Porto: Edições Afrontamento, 1993.

. A desagregação do Império: Portugal e o reconhecimento do Estado brasileiro (1824-1826). Análise Social, vol. XXVIII (121), 1993 (2º, pp. 309341.

Baker, Keith Michel. "Naissance de l'opinion publique", in Annales ESC, jan-fev 1987, $\mathrm{n}^{\mathrm{o}} 1$, pp. 41-71.

Barão de Javari. Organizações e Programas Ministeriais. Regime Parlamentar no Império. Rio de Janeiro: Ministério da Justiça e Negócios Interiores/Arquivo Nacional, 1962. 
Basile, Marcello Octávio Neri de Campos. O Império em construção: projetos de Brasil e ação política na Corte Regencial. Tese de Doutorado apresentada ao Programa de PósGraduação em História Social, Instituto de Filosofia e Ciências Sociais, da Universidade Federal do Rio de Janeiro. Rio de Janeiro, outubro de 2004.

Bosi, Alfredo. A escravidão entre dois liberalismos. In Dialética da colonização. São Paulo: Companhia das Letras, 1994.

Carvalho, José Murilo de. A construção da Ordem. A Elite Política Imperial. Brasília: Ed. Universidade de Brasília, 1980.

Cidadania: tipos e percursos. In Estudos Históricos, Rio de Janeiro, $\mathrm{n}^{\mathrm{o}}$ 18, 1996.

Castro, Paulo Pereira de. A experiência republicana. In História Geral da Civilização Brasileira, Tomo II, $2^{\circ}$ volume, Livro Primeiro. São Paulo: Difusão Européia do Livro, 1964.

Champagne, Patrick. Formar a opinião: o novo jogo político. Petrópolis: Vozes, 1996.

Contier, Arnaldo Daraya. Imprensa e ideologia em São Paulo. Petrópolis: Vozes, 1979.

Cunha, Pedro Otávio Carneiro da. A Fundação de um Império Liberal. História Geral da Civilização Brasileira, tomo 2, volume 1, livro segundo, capítulo V.

Dias, Maria Odila Leite Silva. A interiorização da metrópole e outros estudos. São Paulo: Alameda, 2005, 163 pgs.

Dolhnikoff, Miriam. O pacto imperial. Origens do federalismo no Brasil. São Paulo: Globo, 2005.

Feldman, Ariel. O império das Carapuças, Espaço público e periodismo político no tempo das regências (1832-1839). Dissertação de mestrado, Curitiba, UFPR, 2006 
Flory, Thomas. Judge and jury in imperial Brazil, 1808-1871: social control and political stability in the new State. Austin: University of Texas Press, 1981.

Fonseca, Carla Pereira de Brito. Federação e república na imprensa baiana (18311836). In Lessa, Monica Leite e Fonseca, Silvia Carla Pereira de Brito (orgs.). Entre a monarquia e a república. Imprensa, pensamento político e historiografia (1822-1889). Rio de Janeiro: EDUERJ, 2008.

Foucault, Michel. Vigiar e Punir. Petrópolis: Vozes, 2000.

François-Xavier Guerra. Modernidad y Independencias: ensayos sobre las revoluciones hispanicas. Madrid; México: Editorial MAPFRE: Fondo de Cultura Económica, 1993.

Guimarães, Hélio de Seixas. Os leitores de Machado de Assis. O romance machadiano e o público de literatura no século XIX. São Paulo: Nankin Editorial: Edusp, 2004.

Guimarães, Lúcia Maria Paschoal. Ação, Reação e transação: a pena de aluguel e a historiografia, in Carvalho, José Murilo de (org.). Nação e Cidadania no Império: Novos Horizontes. Rio de Janeiro: Civilização Brasileira, 2007.

Habermas, Jürgen. The Structural Transformation of the Public Sphere. An inquiry into a Category of Bourgeois Society. Cambridge: Polity Press, 1996.

Hespanha, Antonio Manoel. Guiando a mão invisível. Direito, Estado e leis no liberalismo monárquico português. Lisboa: Almenadina, 2004.

Hollanda, Sérgio Buarque de. Raízes do Brasil. São Paulo: Companhia das Letras, 1995

Jancsó, Istvan, e Pimenta, João Paulo G. Peças de um mosaico (ou apontamentos para o estudo da emergência da identidade nacional brasileira), in Mota, Carlos Guilherme (org). Viagem Incompleta: a experiência brasileira (1500-2000). São Paulo: Senac, 2000. 
Jardin, Andre. Historia del libéralismo politico: de la crisis del absolutismo à la Constitución de 1875. México: FCE, 1998.

Jaume, Lucien. El liberalismo posrevolucionario: Francia e Inglaterra. in Orígenes del Liberalismo. Universidad, política, economía. Ricardo Robledo, Irene Castells e María Cruz Romeo (Eds). Salamanca: Ediciones Universidad de Salamanca, 2003.

Koselleck, Reinhart. Crítica e crise: uma contribuição à patogênese do mundo burguês. Rio de Janeiro: EDUERJ, 1999.

Le Goff, Jacques. Documento/Monumento. In História e Memória. Campinas: Editora Unicamp, 2003.

Lima Sobrinho, Barbosa. O problema da imprensa. São Paulo: Com Arte, 1988, 173 pgs.

Lima, Ivana Stolze. Cabra gente brasileira do gentio da Guiné: imprensa, política e identidade no Rio de Janeiro (1831-1833). In Neves, Lucia Maria Bastos Pereira, Morel, Marco, Ferreira, Tania Maria Bessone (orgs.). História e imprensa. Representações culturais e práticas de poder. Rio de Janeiro: DP\&A: Faperj, 2006.

Losurdo, Domenico. Contra-história do liberalismo. Aparecida: Idéias \& Letras, 2006.

Lustosa, Isabel. Insultos impressos: a guerra dos jornalistas na Independência, 18211823. São Paulo: Companhia das Letras, 2000.

Insultos impressos: o nascimento da imprensa no Brasil, in Malerba,

Jurandir. A Independência Brasileira: novas dimensões. Rio de Janeiro: Editora FGV, 2006

Maia, Fernanda Paula Souza. O discurso parlamentar português e as relações PortugalBrasil: a Câmara dos Deputados (1826-1852). Lisboa: Fundação Calouste Gulbenkian, 1992. 
Manin, Bernard. Los principios del gobierno representativo. Madrid: Alianza Editorial, 1998

Melo, José Marques. Sociologia da Imprensa Brasileira. A implantação. Petrópolis: Vozes, 1973.

Monteiro, Tobias. História do império: o primeiro reinado. Belo Horizonte: Itatiaia, São Paulo: EDUSP, 1982

Moreira, Luciano Silva. Imprensa e Política: espaço público e cultura política na província de Minas Gerais, 1828-1842. Dissertação de mestrado. Belo Horizonte, UFMG, 2006.

Morel, Marco e Barros, Mariana Monteiro de. Palavra, imagem e poder: o surgimento da imprensa no Brasil do século XIX. Rio de Janeiro: DP\&A, 2003

Morel, Marco. As transformações dos espaços públicos. Imprensa, atores políticos e sociabilidades na Cidade Imperial (1820-1840). São Paulo: Hucitec, 2005.

Neves, Lucia Maria Bastos P. Liberalismo político no Brasil: idéias, representações e práticas (1820-1823). In Peixoto, Antonio Carlos, Magalhães, Lucia Maria Paschoal e Prado, Maria Emília (orgs.). O Liberalismo no Brasil Imperial: origens, conceitos e prática. Rio de Janeiro: Editora Revan, 2001.

Corcundas e Constitucionais: a cultura política da independência (1820-1823). Rio de Janeiro: Revan: FAPERJ, 2003.

Oliveira, Cecília Helena Lorenzini de Salles. O disfarce do anonimato. O debate político através dos folhetos (1820-1822). Dissertação de Mestrado, São Paulo, USP, 1979.

Pimenta, João Paulo G. A independência do Brasil e o liberalismo português: um balanço da produção acadêmica, em Revista de História Ibero-Americana, vol. 1, número 1, 2008. 
Pitkin, Hanna Fenitchel. The concept of representation. Berkeley: University of California Press, 1984

Ribeiro, Gladys Sabina. Nação e cidadania em alguns jornais da época da Abdicação: uma análise dos periódicos O Repúblico e O Tribuno do Povo. In Lessa, Monica Leite e Fonseca, Silvia Carla Pereira de Brito (orgs.), Entre a monarquia e a república Imprensa, pensamento político e historiografia (1822-1889). Rio de Janeiro: Eduerj, 2008.

Rizzini, Carlos Toledo. O livro, o jornal e a tipografia no Brasil, 1500-1822: com um breve estudo geral sobre a informação. Edição Fac-similar. São Paulo: Imprensa Oficial do Estado, 1988.

Rodrigues, José Honório. A Assembléia Constituinte de 1823. Petrópolis: Vozes, 1974.

Sandroni, Cícero. 180 anos do Jornal do Commercio 1827-2007. De D. Pedro I a Luiz Inácio Lula da Silva. Rio de Janeiro: Quorum Editora, 2007.

Sartori, Giovanni. A teoria da representação no Estado representativo moderno. Belo Horizonte: Revista Brasileira de Estudos Políticos, 1962.

A Teoria da Democracia Revisitada. Volume 1: o debate contemporâneo. São Paulo: Ática, 1994.

Silva, Maria Beatriz Nizza da. Nova História da Expansão Portuguesa. O Império LusoBrasileiro, (1750-1822). Direção de Joel Serrão e A. H. de Oliveira Marques. Lisboa: Editorial Estampa, 1986.

- Movimento constitucional e separatismo no Brasil, 1821-1823. Lisboa: Livros Horizonte, 1988

Silva, Wlamir. A imprensa e a pedagogia liberal na província de Minas Gerais (18251842). In Neves, Lúcia Maria Bastos, Morel, Marco, e Ferreira, Tânia Maria Bessone. História e imprensa: representações culturais e práticas de poder. Rio de Janeiro: DP\&A: Faperj, 2006. 
Slemian, Andréa. Vida política em tempos de crise: Rio de Janeiro (1808-1824). São Paulo: Aderaldo \& Rothschild Editores, 2006. . Um pacto constitucional para um novo Império. Brasil, 1822-1824. Separata de: Visiones y Revisiones de la independência americana - La independência de América: la Constituición de Cádiz y las constituiciones iberoamericanas. Ediciones Universidad de Salamanca, 2007.

Sodré, Nelson Werneck. História da Imprensa no Brasil. Rio de Janeiro: Mauad, 1999.

Sousa, Otávio Tarquínio de. História dos fundadores do Império do Brasil - A vida de D. Pedro I. Rio de Janeiro: Livraria J. Olympio, 1957-58

Fatos e personagens em torno de um regime. Belo Horizonte: Itatiaia, São Paulo: EDUSP, 1988.

Telles Jr, Godofredo da Silva. Justiça e júri no Estado Moderno. São Paulo: Empresa Gráfica da 'Revista dos Tribunais', 1938. Tese de concurso para a cátedra de Direito Judiciário Penal da FDUSP.

Tengarrinha, José. História da imprensa periódica portuguesa. Lisboa: Caminhos, 1989. Da liberdade mitificada à liberdade subvertida: uma exploração no interior da repressão à imprensa periódica de 1820 a 1828. Lisboa: Edições Colibri, 1993.

Vianna, Hélio. Contribuição à história da imprensa: 1812-1869. Rio de Janeiro: Imprensa Nacional, 1945.

Villalta, Luís Carlosa. Censura literária e circulação de impressos entre Portugal e Brasil (1769-1821), in Dutra, Eliana de Freitas e Mollier, Jean-Yves (orgs.). Política, nação e edição: o lugar dos impressos na construção da vida política no Brasil, Europa e Américas nos séculos XVIII-XX. São Paulo: Annablume, 2006. 624 págs. 